\title{
Groei en productie van populier in Nederland
}

\author{
J.J. Jansen ${ }^{1}$, G.M.J. Mohren ${ }^{1}$, P. Schmidt ${ }^{1}$, L. Goudzwaard ${ }^{1}$, \\ A. Oosterbaan ${ }^{2}$ en J. den Ouden ${ }^{1}$
}

FEM Groei en Productie Rapport 2018 - 8

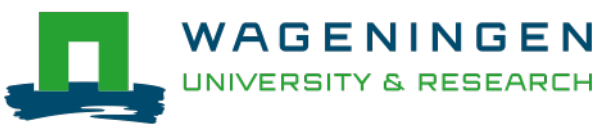

$\begin{array}{ll}1 & \text { Forest Ecology and Forest Management group, Wageningen University, Department of Environmental Sciences } \\ 2 & \text { Nature and Society, Wageningen Environmental Research (WENR) }\end{array}$ 
Jansen, J.J., G.M.J. Mohren, P. Schmidt, L.G. Goudzwaard, A. Oosterbaan en J. den Ouden, 2018. Groei en productie van populier in Nederland. FEM Groei en Productie Rapport 2018 - 8, 127 blz.

Synopsis: Van 1947 tot 1998 is in Nederland groei- en productieonderzoek bij de populier uitgevoerd. Dat betreft de studies van Becking en de Dorschkamp/IBN. Samen met de permanente steekproeven uit de HOSP zijn 235 proefperken met 1808 opnamen beschikbaar. Voor de ontwikkeling van de gemiddelde hoogte $h_{m}$ met de leeftijd $t$ werd het model van Chapman-Richards gekozen, met aanpassing voor dichte stand en verschillende parameters voor bos, lijnbeplantingen en trilpopulier. Als site index is voor de $h_{25}$ gekozen. De diameterontwikkeling tot $7 \mathrm{~m}$ werd het best verklaard met een Gompertz-model in $t, h_{m}$ en het plantverband $S P_{0}$. Met een powerfunctie werd de grondvlakbijgroei $i_{G}$ verklaard met $h_{m}, t, h_{25}$ en de relatieve standruimte $S \%$. Voor $S \%>29.2$ daalt de grondvlakbijgroei met een niet-lineaire functie in $S \%$. Voor dichte stand, lijnbeplantingen werden andere modellen gevonden. Met alle modellen is een opstand projectie model gemaakt, waarmee de gemeten opstandontwikkeling redelijk goed voorspeld werd. Er zijn opbrengsttabellen gemaakt met verschillende plantafstanden voor bos met wijde stand met en zonder systematische dunning, voor bos in dichte stand met sterfte, voor lijnbeplantingen zonder dunning en voor trilpopulier met sterke laagdunning.

Abstract: Between 1947 and 2000, growth and yield of Poplar was studied in the Netherlands. To the permanent plots measured by Becking and De Dorschkamp/IBN, the permanent sample plots from HOSP were added, resulting in 235 plots and 1808 recordings.

The development of the mean height $h_{m}$ with age $t$ was found to be best described by a ChapmanRichards-model, with adjustment factors for dense stand and for different parameters for forest stands, line plantings, and for aspen, using site index $h_{25}$. The diameter development up to a height of $7 \mathrm{~m}$ was best described with a Gompertz-model in $t, h_{m}$ and the initial spacing $\left(S P_{0}\right)$. The basal area increment $I_{G}$ was best explained by a power function in which $h_{m}, a g e, h_{25}$ and the Becking-Hart spacing index $S \%$ are included. For $S \%>29.2$ the basal area increment dropped with a non-linear function in $S \%$. For dense spacing and for line plantings, other models fitted best. Combining all models, a stand projection model was constructed, which described the plot development as measured reasonably well.

Yield tables were made for forests with different spacing, for forests with a wide stand with and without systematically thinning, for forest with very dense spacing including mortality, for line plantings without thinning, and for aspen with heavy thinning from below.

Keywords: Poplar, aspen, Populus spec., Populus tremula, Netherlands, yield tables, different initial spacing, Becking-Hart spacing index, height growth models, power model for basal area increment, systematically and La Bastide-Faber model for thinning effect, mortality and stand projection model.

Dit rapport is gratis te downloaden op: https://doi.org/10.18174/444097

Dit rapport is gebaseerd op de databasen:

1. Mohren, G.M.J., L.G. Goudzwaard, J.J. Jansen, P. Schmidt, A. Oosterbaan, J.F. Oldenburger \& J. den Ouden, 2017. FEM growth and yield data Monocultures - Poplar (revised version). DANS. http://dx.doi.org/10.17026/dans-zu3-256e

2. Ouden, J. den, G.M.J. Mohren \& J.J. Jansen, 2016. FEM growth and yield data - Poplar roadside plantations (revised version). DANS. https://doi.org/10.17026\%2Fdans-xky-zh99 


\section{Voorwoord}

Gedurende de periode 1947 - 1998 zijn er metingen verricht in permanente proefperken van wat tegenwoordig WUR heet. Bartelink et al. (2001) geven een uitgebreid overzicht van de context en publicaties van het groei- en productieonderzoek aan deze en andere boomsoorten in Nederland.

Becking \& De Vries (1959) nemen in hun set opbrengsttabellen twee tabellen op voor de populier, een naar van Laar (1957) en een naar Crocoll (1954). Jansen et al. (1996) kiezen in tabellenboek voor tabel van Faber \& Tiemens (1975).

In een eerder onderzoek naar de groei en productie van douglasopstanden (Jansen et al. 2016) is een nieuw groeimodel ontwikkeld. In deze studie zal onderzocht worden of dit model ook toepasbaar is voor de populier. Daarnaast is er de verwachting dat het model verbeterd kan worden met betrekking tot het effect van wijde plantafstanden op de groei.

In dit rapport wordt de ontwikkeling van opstanden van populier van verschillende klonen, met verschil in plantafstanden en wijze van dunning geanalyseerd met het doel een groeimodel te maken voor de ontwikkeling bij een ruim scala aan beheerstrategieën. Tevens wordt aandacht besteed aan de trilpopulier en aan wegbeplantingen met populier.

De studie is de negende in een serie, waarin eerst de groei en productie van douglas (Jansen et al., 2016), Japanse lariks, fijnspar, grove den, zomereik, beuk, Corsicaanse den en Oostenrijkse den werden bestudeerd.

De studie volgt waar mogelijk dezelfde werkwijze als de voorgaande studies en vaak zijn delen van de tekst uit deze rapporten overgenomen.

Hans Jansen

Wageningen, 2018 


\section{Inhoud}

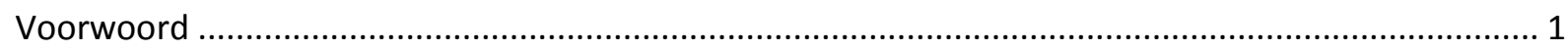

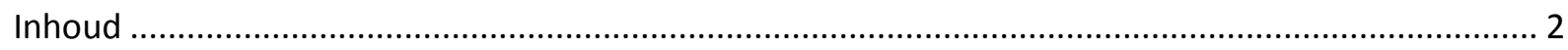

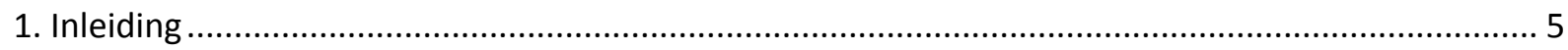

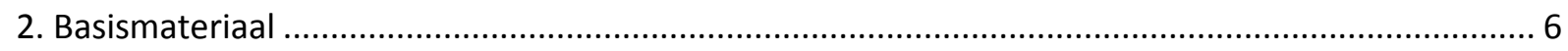

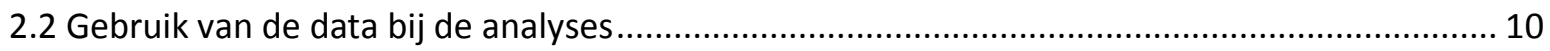

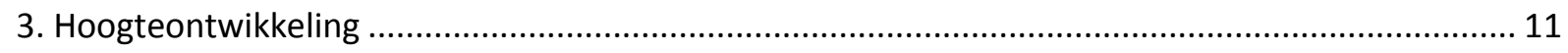

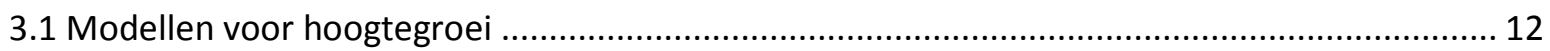

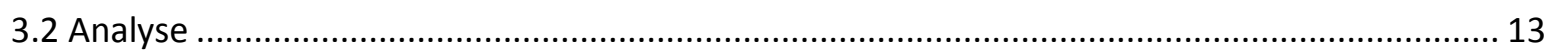

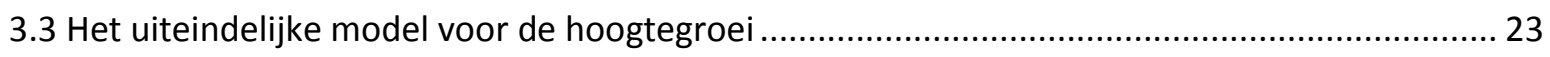

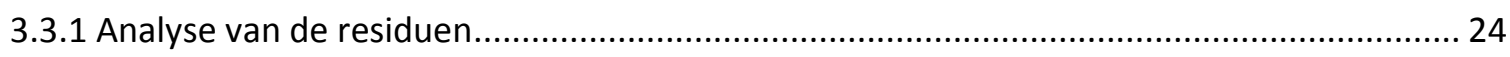

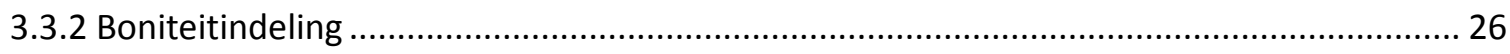

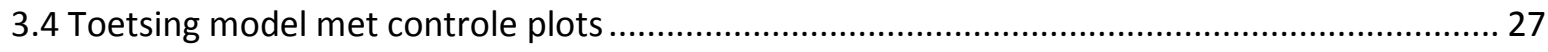

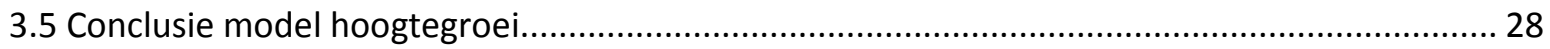

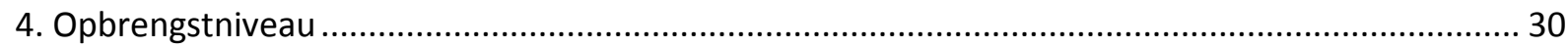

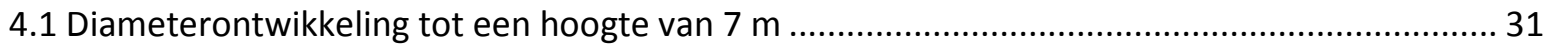

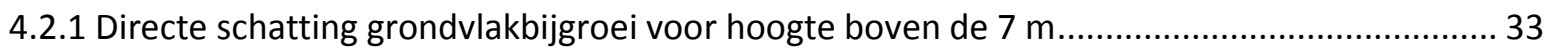

4.2.2 Indirecte schatting grondvlakbijgroei voor hoogte boven de $7 \mathrm{~m} \mathrm{n............................................} 39$

4.2.3 Keuze voor directe of indirecte schatter van grondvlakbijgroei ............................................. 41

4.3 Grondvlakbijgroei voor hoogte boven de $7 \mathrm{~m}$ bij dichte stand................................................. 41

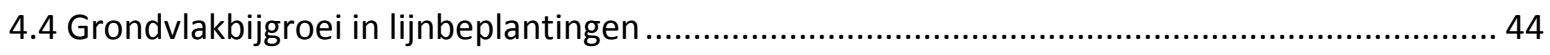

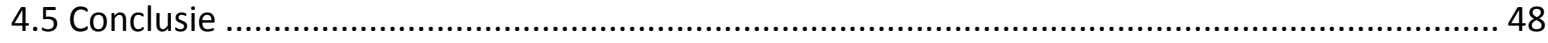

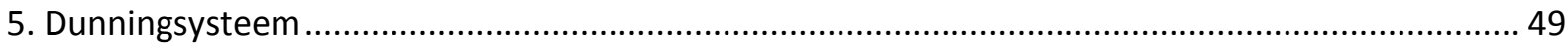

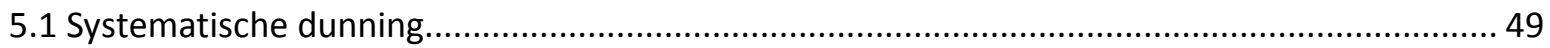

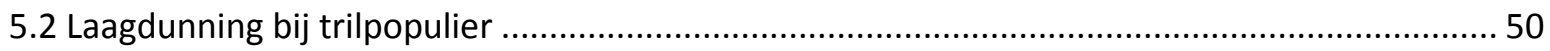

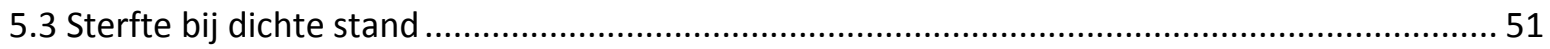

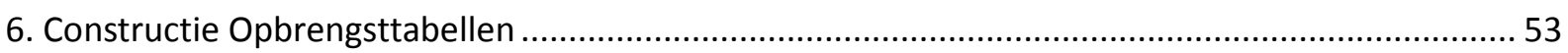

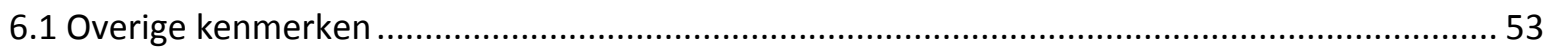

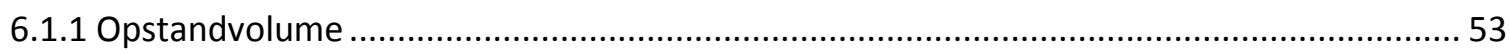

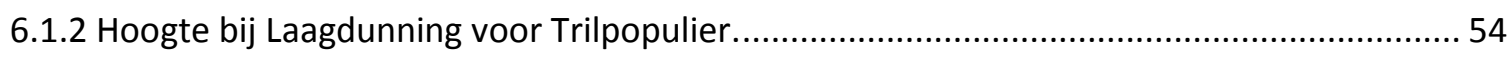

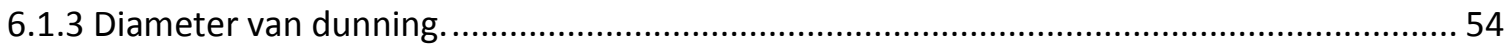

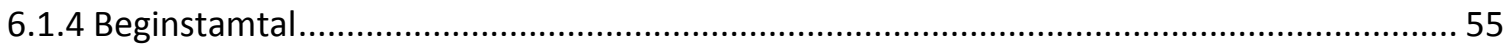

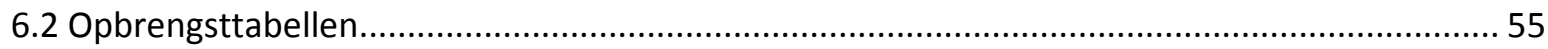




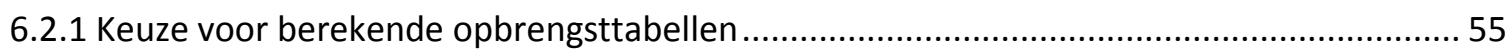

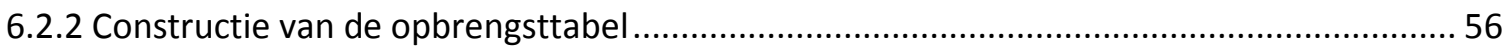

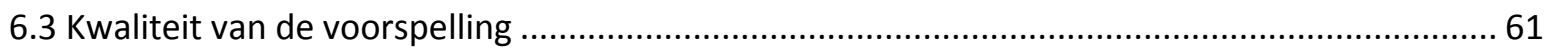

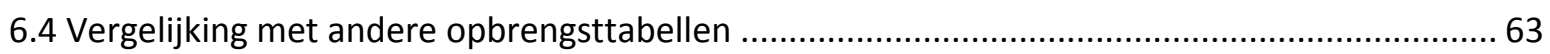

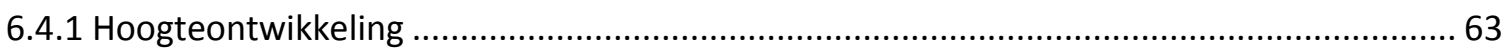

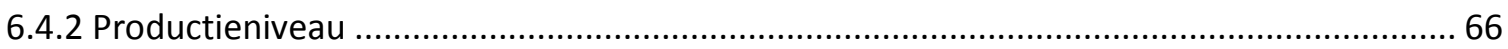

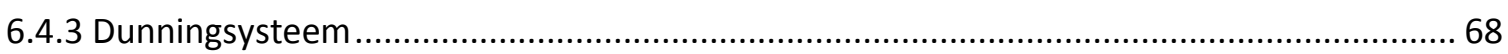

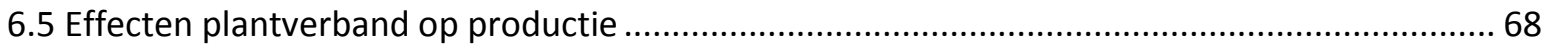

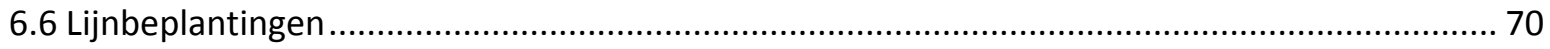

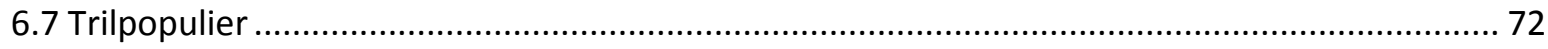

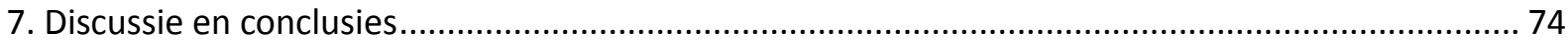

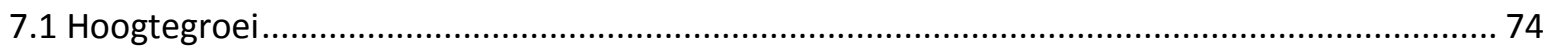

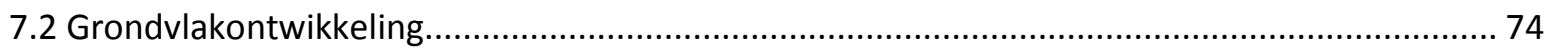

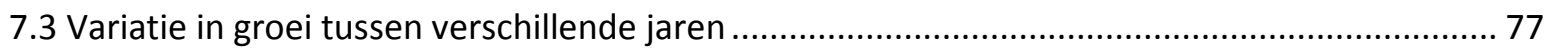

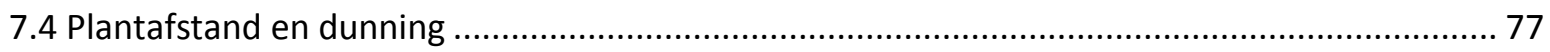

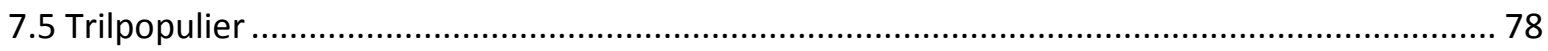

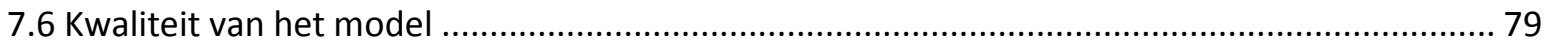

Samenvatting

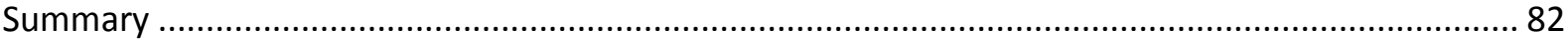

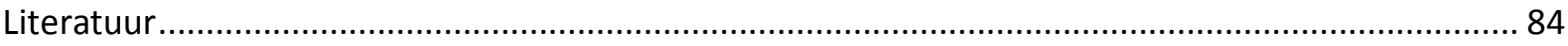

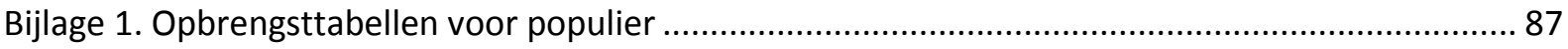

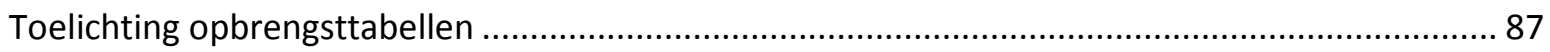

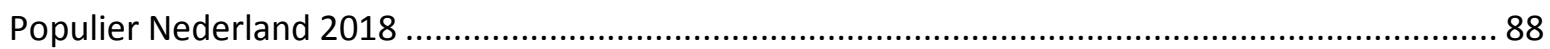

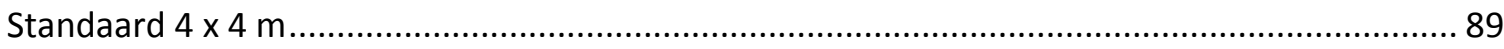

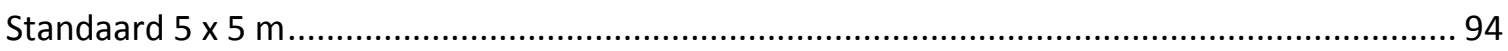

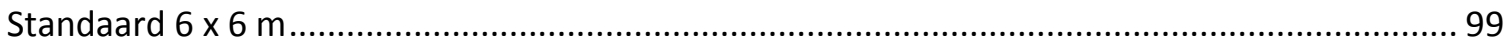

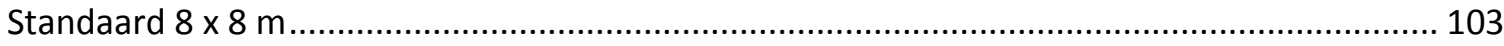

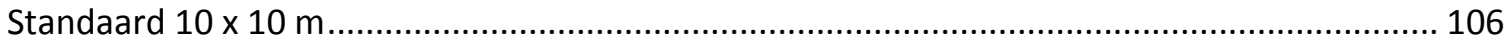

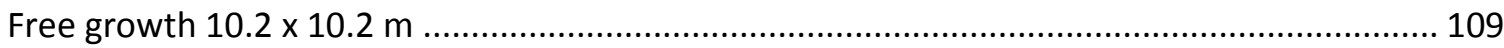

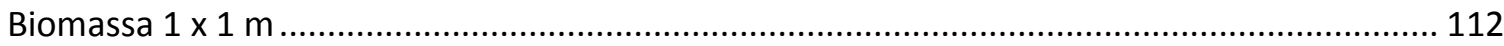

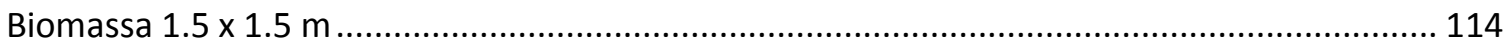

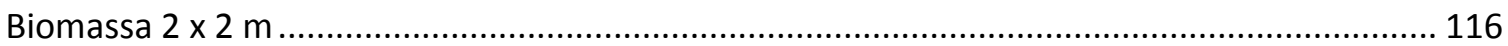

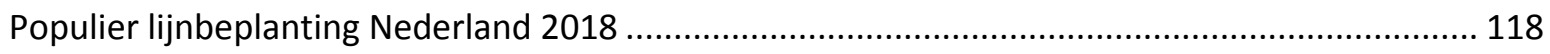

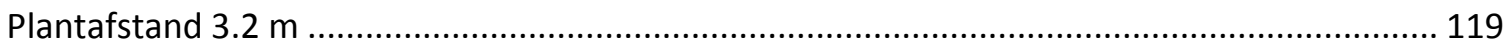


Trilpopulier Nederland 2018 


\section{Inleiding}

Tussen 1947 en 1998 zijn in verschillende studies gegevens verzameld over de groei van populier (Populus L.). Met deze gegevens is het mogelijk modellen te maken die de ontwikkeling van populierenopstanden bij een variatie aan beheerstrategieën verklaren en mogelijk voorspellen. Een van de gebruikelijke modellen is een opbrengsttabel.

Een opbrengsttabel is een model waarmee de opstandontwikkeling in de tijd wordt beschreven en het bestaat meestal uit drie submodellen:

1. Model voor de hoogteontwikkeling, dit wordt In Hoofdstuk 3 besproken;

2. Model voor de grondvlakbijgroei in de tijd of relatief ten opzichte van de hoogte, waarmee het productieniveau van opstanden kan worden voorspeld, dit wordt In Hoofdstuk 4 besproken;

3. Model voor de dunning. Dit model moet een definitie geven van de dunninggraden, daarnaast is het de vraag wat de interactie is met model ad 2 bij verschillende dunninggraden. In Hoofdstuk 5 komen deze vragen aan de orde.

In Hoofdstuk 2 worden de basisgegevens besproken. In Hoofdstuk 6 worden de 3 submodellen geïntegreerd tot een serie opbrengsttabellen. Deze worden vergeleken met andere tabellen en voorspellende kwaliteit van de modellen wordt gekwantificeerd. De tabellen zijn te vinden in Bijlage 1. 


\section{Basismateriaal}

Sinds 1947 is in Nederland onderzoek gedaan naar de ontwikkeling van populierenopstanden. In dit onderzoek is gebruik gemaakt van gegevens uit de volgende studies en datasets:

1. Dunningonderzoek Becking 1947-1992. Dit onderzoek betrof 12 verschillende boomsoorten in Nederland met ongeveer 400 proefperken, waarvan 58 perken met populier. Van een gestuurde behandeling is bij de populier nauwelijks sprake. Het betreffen verschillende populierensoorten en cultivars met een grote verscheidenheid aan plantverband. In één perk is een stamanalyse uitgevoerd. In principe is er sprake van een systematische dunning. Maar omdat het plantverband bij aanvang al zo wijd was dat die dunning nooit nodig was is er ook sprake van behandeling zonder dunning. Deze behandeling zonder dunning kwam ook voor omdat een geplande dunning niet werd uitgevoerd. Bij een enkel proefperk kwam laagdunning voor, zie Tabel 2 voor een overzicht;

2. Groei- en productieonderzoek Dorschkamp. Dit onderzoek is opgezet ten behoeve van het opstellen van opbrengsttabellen en volumetabellen. De totale omvang is onbekend. Er zijn gegevens beschikbaar van 76 proefperken met verschillende populierensoorten en cultivars met een grote verscheidenheid aan plantverband. Het onderzoek liep vermoedelijk van 1950 - 1985, helaas zijn de opnamedata niet bewaard gebleven;

3. IBN Plantafstand Proeven. Dit zijn 2 permanente proefveldcomplexen met ieder 3 proefperken. Het onderzoek liep vermoedelijk van 1975 - 1990, helaas zijn de opnamedata niet bewaard gebleven;

4. HOSP 1984-2000. Dit zijn ca. 3000 permanente steekproefpunten uit de $4^{\mathrm{e}}$ bosstatistiek in beheer bij de Stichting Probos. Hieruit zijn 42 monocultures met populier geselecteerd met 3 of meer opnamen. Er is geen sprake van een behandeling in het onderzoek, maar de ontwikkeling inclusief de door de eigenaren/beheerders uitgevoerde dunning wordt gevolgd.

8. Nelder Standruimte Proeven 1976-1998. Er zijn 3 permanente Nelderproefvelden (Nelder,1962) met populier. leder proefveld bestaat uit 6 tot 9 series met gelijke standruimte per boom, daarnaast nog 3 series met randbomen. Er zijn 3 cultivars onderzocht zonder dunning. Een serie binnen het Nelderproefveld wordt gezien als een proefperk. Totaal zijn dat 21 proefperken, die zijn echter onderling niet onafhankelijk;

13. Weg- en grensbeplantingen 1951-1997. Er zijn 32 permanente proefvakken met populier, hier verder aangeduid als lijnbeplantingen.

In totaal zijn op basis van bovengenoemde studies en data sets 1808 opnamen in 235 proefperken in de huidige studie opgenomen. De proefvelden betreffen, behalve die van studie 4 8 en 13, proefvakken een zekere vaste oppervlakte bos. In studie 4 gaat het om vaste steekproefpunten met een variërende straal zodanig dat er minimaal 25 bomen in de steekproef liggen. Door kap of ingroei kan deze wijzigen. Alleen dat deel wat in alle opnamen aanwezig was is bij het onderzoek betrokken. Voor studie 13 gaat het om een vast lengtetraject, zonder een gedefinieerde breedte en oppervlakte. Voor het gebruik in dit onderzoek zijn de basisgegevens geconverteerd naar oppervlakte door gebruik te maken van de conversiefactor $1 \mathrm{~km} \equiv 1$ ha, dit gaat uit van een hypothetische breedte van $10 \mathrm{~m}$. Het CBS (1989) hanteert overigens een conversiefactor van $1 \mathrm{~km} \equiv 0.8$ ha.

Voor de proefvelden van studie 8 zie Figuur 1. 
Voor het bepalen van de dunninggraad is het S-procent van Hart (1928) (ook bekend als de Hart-Becking Spacing Index) van alle perken en opnamen berekend met formule (1):

$$
S \%=\frac{s p_{a t}}{h_{a t}} \cdot 100=\frac{100}{h_{a t}} \cdot \sqrt{\frac{10000}{N_{a t}}}
$$

In deze definitie is de gemiddelde boomafstand na dunning ( $s p_{a t}$ ) bepaald met een regelmatig vierkantverband. Het symbool $h_{a t}$ staat voor de gemiddelde hoogte na dunning. Normaliter wordt gekozen voor een driehoekverband en wordt de relatieve standruimte uitgedrukt ten opzichte van de opperhoogte, maar aangezien populier meestal in een rechthoekig verband wordt aangelegd en de opperhoogte geen ideale maat voor de opstandhoogte bij klonen is gekozen voor deze versie voor het $S \%$.

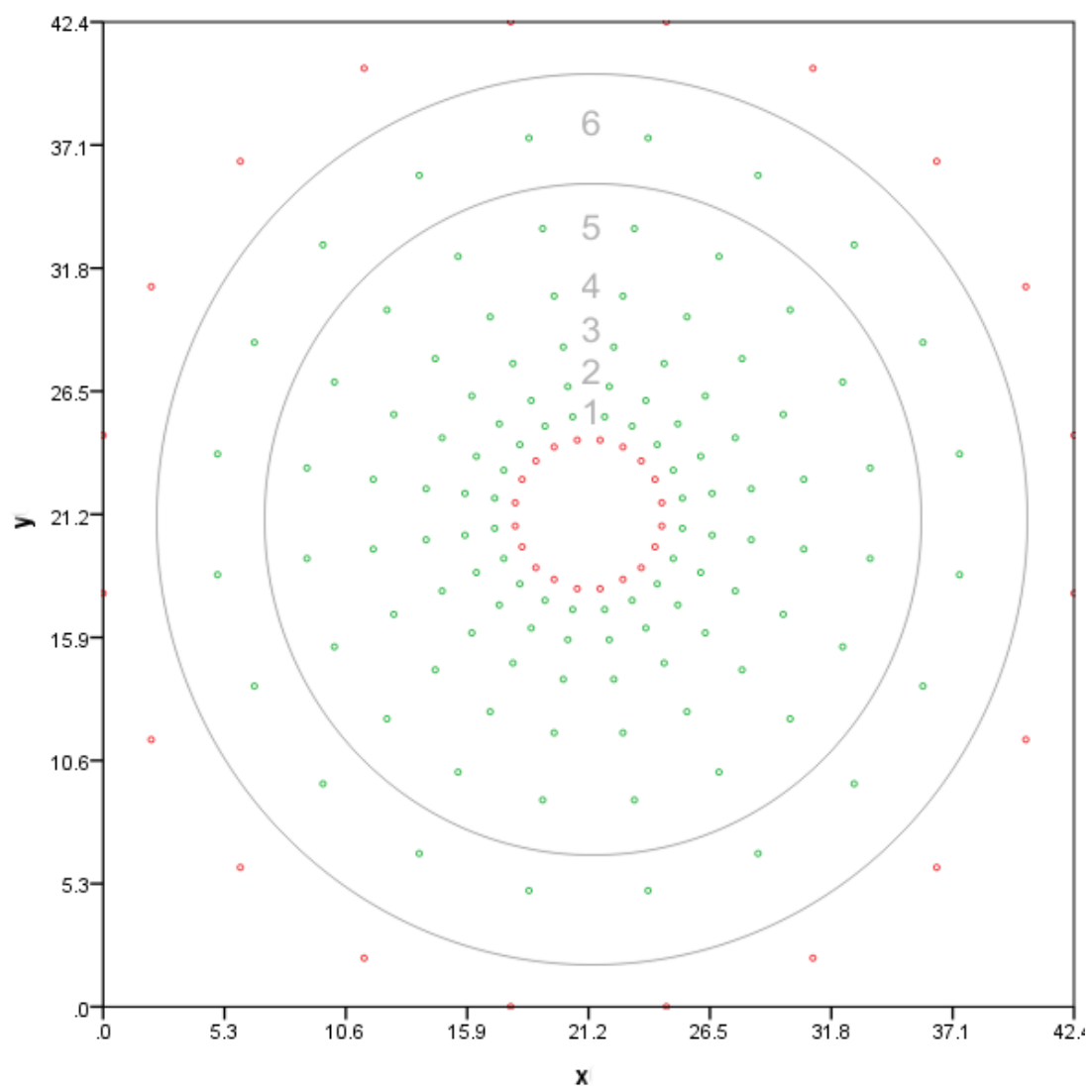

Figuur 1. Stamvoetenkaart Nelder plot P312 Horsterbos. De rode punten betreffen de coördinaten van de randbomen. De groene punten die van de proefbomen. De bomen op cirkel 6 liggen binnen de twee weergegeven grenscirkels en vormen samen een proefperk. De bomen op de cirkels 1, 2, 3, 4 en 5 vormen per cirkel eveneens een proefperk, hier zijn bijbehorende grenscirkels niet getekend.

Figure 1. Tree position map of plot P312 Horsterbos. Green dots represent the positions of plot trees, red dots represent border trees. The trees within circle 6 are located between the outer and inner border circle and together represent one experimental plot. The trees on the circles 1, 2, 3, 4 and 5 represent 5 experimental plots (no border circles drawn). 
Proefperken liggen normaliter in een opstand, waarbij de bomen in het proefperk dezelfde behandeling ondergaan als die in de naaste omgeving van het proefperk (meestal aangeduid als bufferzone). Bij de Nelderproeven is daar geen sprake van (zie Figuur 1).

\subsection{Algemene gegevens proefperken}

Van alle proefperken van de studies 1, 4, 8 en 13 en ook van 5 proefperken met trilpopulier van studie 2 zijn basisgegevens als oppervlakte (ha), stekjaar, cultivar/soort en ligging bekend. Bij de ligging is onderscheid gemaakt tussen de regio's Noord (Drenthe, Friesland en Groningen, kop van Overijssel), Midden (rest Overijssel, Gelderland, Flevoland, Utrechtse Heuvelrug en Vallei en het Gooi), Zuid (Noord-Brabant en Limburg), West (Noord-Holland, Zuid-Holland, westelijke deel Utrecht en Zeeland (exclusief het duingebied), en Kustgebied (Waddeneiland en duingebieden in Holland en Zeeland).

In Tabel 1 is aangegeven welke cultivars of soorten het vaakst per proefperk en per studie voorkomen.

Tabel 1. Hoofdboomsoort of cultivar per studie.

Table 1. Main tree species or cultivar per study

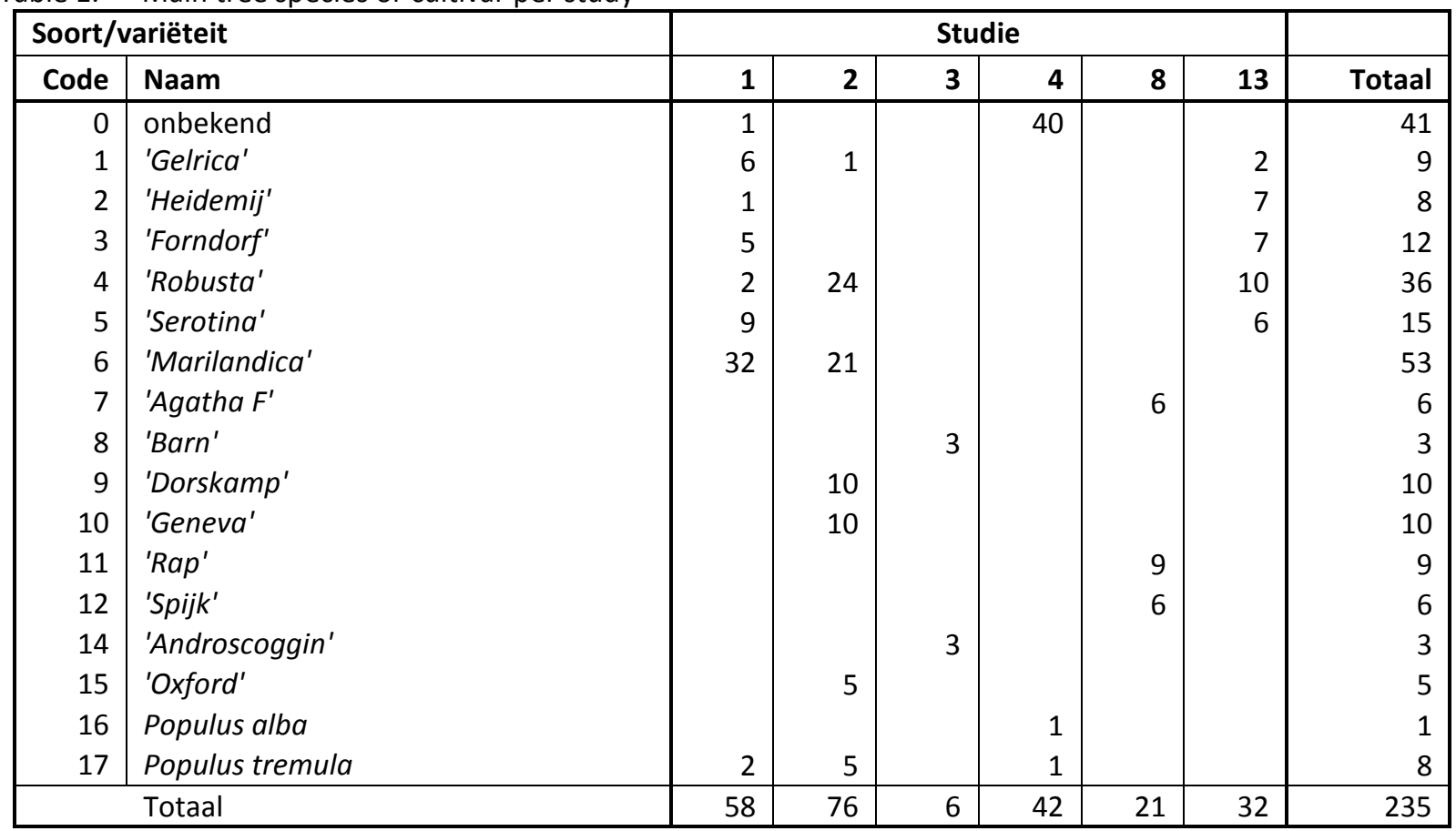

In veel gevallen is bij aanleg gebruik gemaakt van de hulpboomsoort zwarte els, deze zijn vaak meerdere keren afgezet en later zo goed als verdwenen. Ze zijn echter nooit gemeten.

Bij de perken 1, 7, 31, 32, 33, 34, 177, 179, 188, 191, 192, 196 en 197 is sprake van een zogenaamde boomweide.

Bij perk 12 (Best 9) is bij aanleg fijnspar tussen de populier aangeplant. Omdat de hoogtegroei van de fijnspar sterk achterblijft bij die van de populier is dit proefperk opgenomen bij studie 1 als een monocultuur (dus zonder de fijnspar). Maar daarnaast is dit proefperk ook 
geregistreerd bij de meetseries van de gemengde proefperken (in data base "FEM growth and yield data Mixed species forest", Bartelink et al., 2016).

In perk 20 (Maas en Waal 6) is sprake van een wilgenhakgriend in de ondergroei, dit is niet gemeten.

In Tabel 2 is een overzicht gegeven van de behandelingen per studie.

Tabel 2. Behandeling in dunning per studie

Table 2. Thinning treatment per study.

\begin{tabular}{|l|rrrr|r|}
\hline & $\begin{array}{r}\text { zonder } \\
\text { dunning }\end{array}$ & $\begin{array}{r}\text { Zonder dunning } \\
\text { met sterfte }\end{array}$ & $\begin{array}{r}\text { systematische } \\
\text { dunning }\end{array}$ & laagdunning & totaal \\
\hline WU Dunningproeven Becking & 30 & 25 & 3 & 0 & 58 \\
Dorschkamp/IBN & 35 & 36 & 5 & 0 & 76 \\
IBN plantafstand proeven & 0 & 0 & 0 & 6 & 6 \\
HOSP & 9 & 31 & 2 & 0 & 42 \\
IBN Nelder proeven & 0 & 0 & 0 & 21 & 21 \\
Lijnbeplantingen & 12 & 20 & 0 & 0 & 32 \\
\hline Totaal & 86 & 112 & 10 & 27 & 235 \\
\hline
\end{tabular}

Per proefperk en opname zijn de gegevens beschikbaar, zoals vermeld in Tabel 3.

Voor een volledige beschrijving van gemeten en berekende gegevens bij de oppervlakteproefperken zie de file "Read me - FEM growth and yield data Monocultures - Poplar.pdf" in de database "FEM growth and yield data Monocultures - Poplar (revised version)" (Mohren et al., 2017) en voor de lijnbeplantingen de file "Read me - FEM growth and yield data - Poplar roadside plantations.pdf" in de database "FEM growth and yield data - Poplar roadside plantations (revised version)" (den Ouden et al., 2016). 
Tabel 3. Basisgegevens per plot en opname na conversie van de lijnbeplantingen.

Table 3. Base information per plot and recording after conversion of the line plantations.

\begin{tabular}{|c|c|}
\hline Symbool & Betekenis \\
\hline plotnr & Plotnummer \\
\hline study & Studienummer \\
\hline region & Regio \\
\hline area & Plot oppervlakte in ha \\
\hline yog & Kiemjaar of stekjaar \\
\hline$N_{0}$ & Beginstamtal \\
\hline var & Soort of kloon \\
\hline MS & Beheersysteem \\
\hline nrec & Aantal opnamen \\
\hline rec & Opname nummer \\
\hline DOR & Datum van de opname \\
\hline age & Leeftijd in jaar \\
\hline$N \_b t$ & Stamtal per ha voor dunning \\
\hline G_bt & Grondvlak voor dunning in $\mathrm{m}^{2} /$ ha \\
\hline$h \_b t$ & Gemiddelde hoogte in $\mathrm{m}$ voor dunning \\
\hline$d \_b t$ & Diameter van de grondvlak-middenstam in $\mathrm{cm}$ voor dunning \\
\hline$V \_b t$ & Volume voor dunning in $\mathrm{m}^{3} / \mathrm{ha}$ \\
\hline N_th & Stamtal per ha van de dunning \\
\hline G_th & Grondvlak van de dunning in $\mathrm{m}^{2} /$ ha \\
\hline$h \_t h$ & Gemiddelde hoogte in $\mathrm{m}$ van de dunning \\
\hline d_th & Diameter van de grondvlak-middenstam in $\mathrm{cm}$ van de dunning \\
\hline$V_{-} t h$ & Volume van de dunning in $\mathrm{m}^{3} / \mathrm{ha}$ \\
\hline N_at & Stamtal per ha na dunning \\
\hline G_at & Grondvlak na dunning in $\mathrm{m}^{2} / \mathrm{ha}$ \\
\hline h_at & Gemiddelde hoogte in $\mathrm{m}$ na dunning \\
\hline d_at & Diameter van de grondvlak-middenstam in $\mathrm{cm}$ na dunning \\
\hline$V \_a t$ & Volume na dunning in $\mathrm{m}^{3} / \mathrm{ha}$ \\
\hline
\end{tabular}

\subsection{Gebruik van de data bij de analyses}

Alle data behalve die van studie 4 (HOSP) worden gebruikt bij het ontwikkelen van de modellen in de hoofdstukken 3, 4 en 5. Het betreft 1663 opnamen in 193 proefperken. In hoofdstuk 6 worden de ontwikkelde modellen geïntegreerd in een set opbrengsttabellen en een 'stand projection' model. Met dit laatste model wordt, gebruik makend van diverse functies waarmee de opbrengsttabel wordt gemaakt, de groei voorspeld van opstanden, ook als de huidige opstandkarakteristieken niet voldoen aan de waarden in de opbrengsttabel. In paragraaf 6.3 wordt de kwaliteit van dit opstand projectie model getoetst voor zowel de gebruikte data uit de studies 1,2, 3 en 8 als voor de praktijksituaties van de HOSP-data van studie 4. Dat laatste gaat om 145 opnamen in 42 steekproefpunten. Deze HOSP-studie dient dus als een onafhankelijke controle set. In Paragraaf 5.2 echter is het HOSP plot 160 wel meegenomen bij de analyse. 


\section{Hoogteontwikkeling}

Voor het modelleren van de hoogtegroei is het gebruikelijk te werken met de opperhoogte $\left(h_{\text {top }}\right)$ of de dominante hoogte $\left(h_{\text {dom }}\right)$, omdat dit in beide gevallen een dominante boom betreft. Dit soort bomen wordt maar zelden gedund, althans in de laagdunning waarmee de meeste proefperken zijn beheerd, waarmee de verandering een echte dynamiek betreft en geen statistische verandering ten gevolge van dunning. Maar bij cultivars met systematische dunning en zeer wijde plantverbanden zoals bij de populier heeft deze maat geen waarde en is gewerkt met de gemiddelde hoogte. Om het eventuele toevallig effect van dunning op de hoogte te minimaliseren is de gemiddelde hoogte al volgt gedefinieerd:

$$
h_{m}=\frac{\bar{h}_{b t}+\bar{h}_{a t}}{2}
$$

Daarnaast is er een ander probleem bij het gebruik van populierenstekken, deze waren bij de oude cultivars 'Gelrica', 'Heidemij', 'Forndorf', 'Marilandica', 'Robusta' en 'Serotina' meestal tweejarig en ongeveer $1.5 \mathrm{~m}$ lang. Maar ook wel eenjarig van $1 \mathrm{~m}$ of driejarig van 2 m. Bij de nieuwe cultivars 'Barn', 'Geneva', 'Rap' en 'Spijk' is tweejarige stek ongeveer $2.5 \mathrm{~m}$ lang en bij 'Agatha $\mathrm{F}$ ' is gebruik gemaakt van eenjarige stek die gemiddeld $2.4 \mathrm{~m}$ lang was. $\mathrm{Er}$ is daarom bij de analyse gewerkt met een aangepaste leeftijd en hoogte vanaf het moment van planten:

$$
\begin{aligned}
& h_{a d j}=h_{m}-h_{0} \\
& t_{a d j}=t-t_{0}
\end{aligned}
$$

where $h_{0}$ and $t_{0}$ are the height and age of the cutting

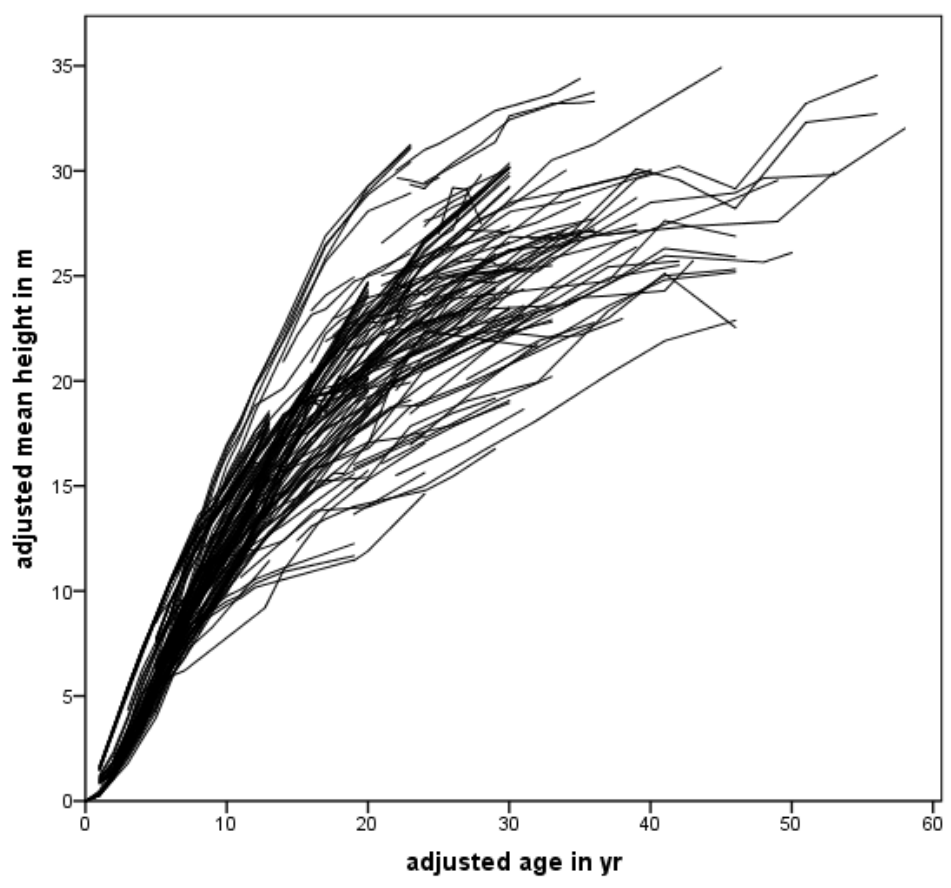

Figuur 2. Aangepaste hoogteontwikkeling van de analyse proefperken.

Figure 2. Development of adjusted tree height for the analyse plots. 
In Figuur 2 is de hoogteontwikkeling gegeven van de met formule (3) gecorrigeerde hoogte en leeftijd van de analyse plots.

Bij de plots met trilpopulier zijn in alle gevallen de $h_{0}$ en $t_{0}$ op nul gesteld, hier start de hoogteontwikkeling dus op de gebruikelijke wijze in het nulpunt.

\subsection{Modellen voor hoogtegroei}

In de huidige Nederlandse opbrengsttabel voor de populier van Faber \& Tiemens (1975) is het zogenaamde Chapman-Richards model gebruikt:

$$
h_{m}=S \cdot\left(1-e^{-a \cdot t}\right)^{b} \quad \text { for } h \geq 8 \mathrm{~m}
$$

Model (4) bevat soortspecifieke parameters ( $a$ en $b$ ) en proefperkspecifieke parameters (S).

In model (4) is $S$ de zogenaamde "site index" de proefperkspecifieke parameter. Deze $S$ kan gezien worden als de afplattingshoogte en het is tevens een maat voor de boniteit, in dit geval een absolute hoogteboniteit. In gebruikte meetseries (zie Figuur 2) lijkt deze afplattingshoogte bij ongeveer 35 jaar te zijn bereikt, van topsterfte was in enkele gevallen sprake. $\mathrm{Er}$ zijn echter 2 proefperken ( $\mathrm{nr} .17$ Loenen 1 en nr. 30 Nuenen 4) waarin de hoogte ook boven de 40 jaar nog toeneemt.

Het model om de hoogteontwikkeling te beschrijven moet voldoen aan de volgende eisen:

1. Het model moet een rechtscontinu stijgende functie in de leeftijd zijn, met een asymptoot die overeenkomt met de verwachte afplattingshoogte. De hoogste gemeten boom in de dataset was $39.8 \mathrm{~m}$ en de grootste gemiddelde hoogte was $36.9 \mathrm{~m}$. Bij de opname voor de $4^{\mathrm{e}}$ bosstatistiek (CBS, 1985) is de opperhoogte per opstand geschat. De hoogste waarde voor populier bedroeg $36 \mathrm{~m}$. De maximale S-waarde voor de beste boniteit voor de populier zal daarom ongeveer 39 m moeten zijn. Jansen et al. (1996) gebruikten als maximale S-waarde in hun bewerking van de tabel van Faber \& Tiemens (1975) voor de beste groeiklasse $45.3 \mathrm{~m}$. Dit lijkt dus een overschatting. In het model met $h_{\text {adj }}$ zal de Swaarde daarom maximaal 37 à $38 \mathrm{~m}$ mogen zijn;

2. Een andere eis kan gesteld worden aan de aangepaste hoogte bij een bepaalde aangepaste leeftijd, op basis van Figuur 2 komt daarom 25 jaar voor in aanmerken, de $h_{\text {adj25 }}$ moet tussen 15 en 32 m liggen;

3. Op het aangepaste tijdstip 0 moet de aangepaste hoogte ook 0 zijn. Daarna moet de groei in de jeugd langzaam op gang komen en afhankelijk van de cultivar zal de groei in het eerste jaar 0.5 tot $2.0 \mathrm{~cm}$ zijn;

4. De hoogtegroei versnelt tot de aangepaste hoogte $\left(h_{\text {adj }}\right)$ ongeveer 5 meter bedraagt. Het buigpunt van de curve zal zeker tussen de 3 en 8 m moeten liggen (zie Figuur 3);

5. De algemene maat voor de verklaring (hiervoor is $R^{2}$ adj gebruikt) moet hoog zijn; 
6. De kwaliteit van de schatter van boniteit-parameters door naar de variatiecoëfficiënt CV ervan te kijken. Indien het model voor alle proefperken geschikt is, zal het $95 \%$ betrouwbaarheidsinterval van CV klein zijn;

7. De parameterschattingen moeten significant zijn.

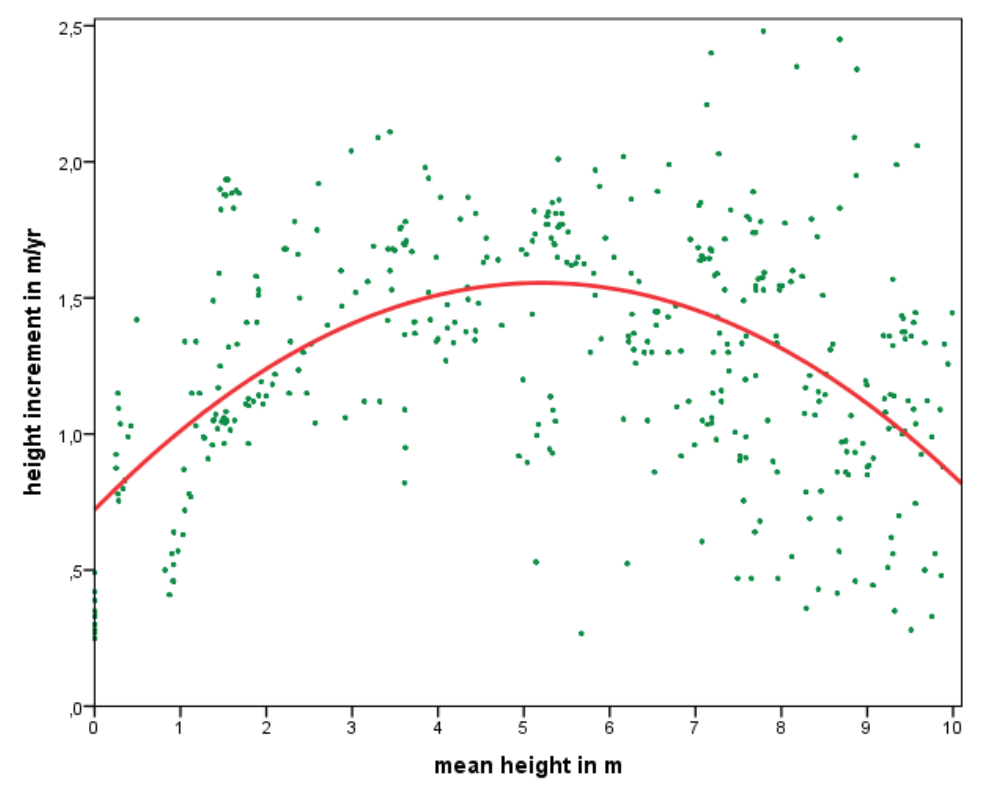

Figuur 3. Hoogtebijgroei als functie van de aangepaste hoogte voor $h_{a d j} \leq 10 m$. Met de rode lijn is de kwadratische fit aangegeven door de puntenwolk, met een maximum voor $i_{h}$ bij $h_{\text {adj }}=5.2 \mathrm{~m}$

Figure 3. Height increment as a function of the adjusted height for $h_{a d j} \leq 10 \mathrm{~m}$. The red line shows the quadratic fit through the measured points, with a maximum at $h_{\text {adj }}=5.2 \mathrm{~m}$.

In principe kunnen naast de bekende groeifuncties ook kansverdelingen aan bovenstaande eisen voldoen, maar ook functies zonder asymptoot kunnen gebruikt worden door een maximale hoogte bij een grensleeftijd te definiëren. Hiernavolgend zullen voornamelijk modellen voor de hoogtegroei worden onderzocht met een asymptoot.

\subsection{Analyse}

Het onderzoek naar het hoogtegroeimodel is in 4 stappen uitgevoerd. Er zijn voor de analyse van de hoogtegroei gegevens gebruikt uit 193 proefperken met in totaal 1663 opnamen.

Bij het ontwikkelen van het hoogtegroeimodel zijn de volgende onderzoekvragen relevant:

1. Welk model voldoet het best? (Stap 1);

2. Faber (1985) en Houtzagers en Schmidt (1994) geven aan dat in een aantal Nelderproefvelden in Flevoland er een relatie is tussen de hoogteontwikkeling en de standruimte. De vraag is hoe dit fenomeen het model beïnvloed (Stap 2); 
3. Faber en Tiemens (1975) kiezen voor een standaard parameter-set voor de hoogte groei maar geven aan dat er verschillen per cultivar zijn. De vraag is hoe dat in de huidige dataset uitpakt (Stap 3), daarnaast is het de vraag of het uitmaakt of het om een bosbeplanting of een lijnbeplanting van die kloon gaat;

4. Voldoet het model voor heel Nederland of zijn er regionale verschillen (Stap 4).

In Paragraaf 3.3 zullen de resultaten in een totaal model worden gepresenteerd, een indeling boniteiten worden ontworpen. In Paragraaf 3.4 wordt dit model getoetst met de data van de controle set.

\section{Stap 1. Modelkeuze}

De volgende vijf modellen zijn onderzocht.

1. Het homomorfe model van Chapman-Richards (zie Pienaar \& Turnbull, 1973):

$$
h_{a d j}=S \cdot\left(1-e^{-a \cdot t_{a d j}}\right)^{b}
$$

2. Burkhart \& Tennent (1977) paste het Chapman-Richard model aan door de parameter $a$ als functie van $S$ uit te drukken waardoor een heteromorf model ontstaat:

$$
h_{a d j}=S \cdot\left(1-e^{-\left(a_{0}+a_{1} \cdot S\right) \cdot t_{a d j}}\right)^{b}
$$

3. Jansen \& Hildebrand (1986) pasten de werkwijze van Burkhart \& Tennent toe op de $b$-parameter, hierdoor ontstaat eveneens een heteromorf model:

$$
h_{a d j}=S \cdot\left(1-e^{-a \cdot t_{a d j}}\right)^{\left(b_{0}+b_{1} \cdot S\right)}
$$

4. Jansen et al. (2016) pasten model (7) aan door een jeugdgroei-component toe te voegen gebaseerd op het model van Korf (1939):

$$
\begin{aligned}
h_{a d j}= \begin{cases}f_{1}\left(t_{a d j}\right)=x \cdot \frac{e^{-a_{k} \cdot t_{a d j}^{-c}}}{e^{-a_{k} \cdot t_{x}^{-c}}} \quad \text { for } t_{a d j} \leq t_{x} \\
f_{2}\left(t_{a d j}\right)=S \cdot\left(1-e^{-a \cdot t}\right)^{\left(b_{0}-b_{1} \cdot S\right)} \quad \text { for } t_{a d j}>t_{x}\end{cases} \\
\text { where } t_{x}=-\frac{\ln \left(1-(x / S)^{1 / b}\right)}{a} \text { for } h_{a d j}=x \text { and } a_{k}=\frac{a \cdot b \cdot(S / x) \cdot e^{-a \cdot t_{x}} \cdot\left(1-e^{-a \cdot t_{x}}\right)^{b-1}}{c \cdot t_{x}^{-c-1}}
\end{aligned}
$$

Voor de grenswaarde voor de jeugdgroei is $x=5.2$ meter aangehouden

5. Het Cieszewski model (2001) gebruikt een referentieleeftijd, voor $t_{a d j}=25$ jaar luidt het: 


$$
h_{a d j}=h_{25 a d j} \cdot \frac{t_{a d j}^{a} \cdot\left(25^{a} \cdot R+b\right)}{25^{a} \cdot\left(t_{a d j}^{a} \cdot R+b\right)}, \text { where } R=Z+\sqrt{Z^{2}+\frac{2 \cdot b \cdot h_{25 a d j}}{25^{a}}} \text { and } Z=h_{25 a d j}-c
$$

Dit heteromorfe model heeft wel een asymptoot, maar de oplossing moet gevonden worden met formule (9). Johansson (2011) concludeerde in zijn groeistudie voor populier in Zweden dat het model van Cieszewski het beste resultaat gaf.

Een probleem bij het schatten van de parameters van de modellen is dat naast de 2 of 3 parameters van het model ook de boniteit (de 193 proefperkparameters $S$ of $h_{\text {ref }}$ ) moeten worden geschat. "Zo wordt bijvoorbeeld het Chapman-Richards model (5) herschreven tot

$$
h_{a d j, i j}=\left(\sum_{i=1}^{193} S_{i} \cdot x_{i}\right) \cdot\left(1-e^{-a \cdot t_{a d j, i j}}\right)^{b} \text { for the } j^{\text {th }} \text { recording in the } i^{\text {th }} \text { plot }
$$

Hierin is $x_{i}$ een variabele die 1 is in het $i^{\text {de }}$ perk en 0 elders.

Om dit probleem te vermijden geven La Bastide en Faber (1972) een oplossing, door niet $h_{\text {top }}$ te schatten maar de relatieve groei ervan:

$$
y=\frac{d h_{t o p}}{d t} \cdot \frac{1}{h_{t o p}}=\frac{\left(h_{t o p 2}-h_{t o p 1}\right)}{\left(t_{2}-t_{1}\right) \cdot\left(h_{t o p 1}+h_{t o p 2}\right) / 2}
$$

Met de huidige rekencapaciteit is dat niet meer nodig, maar hiermee kunnen wel goede beginschatters voor de modelparameters worden gevonden.

In Figuur 4 is deze relatieve groei tegen de leeftijd uitgezet, met de hier getoonde grote variatie zal een duidelijk beste model niet eenduidig te bepalen zijn. De waarnemingen met een aangepaste hoogte beneden de 5 à $10 \mathrm{~m}$ hebben een zeer grote invloed op keuze voor de groeicurve (Figuur 4). In de meeste opbrengsttabellen wordt de moeilijk te modelleren jeugdgroei dan ook weggelaten. 


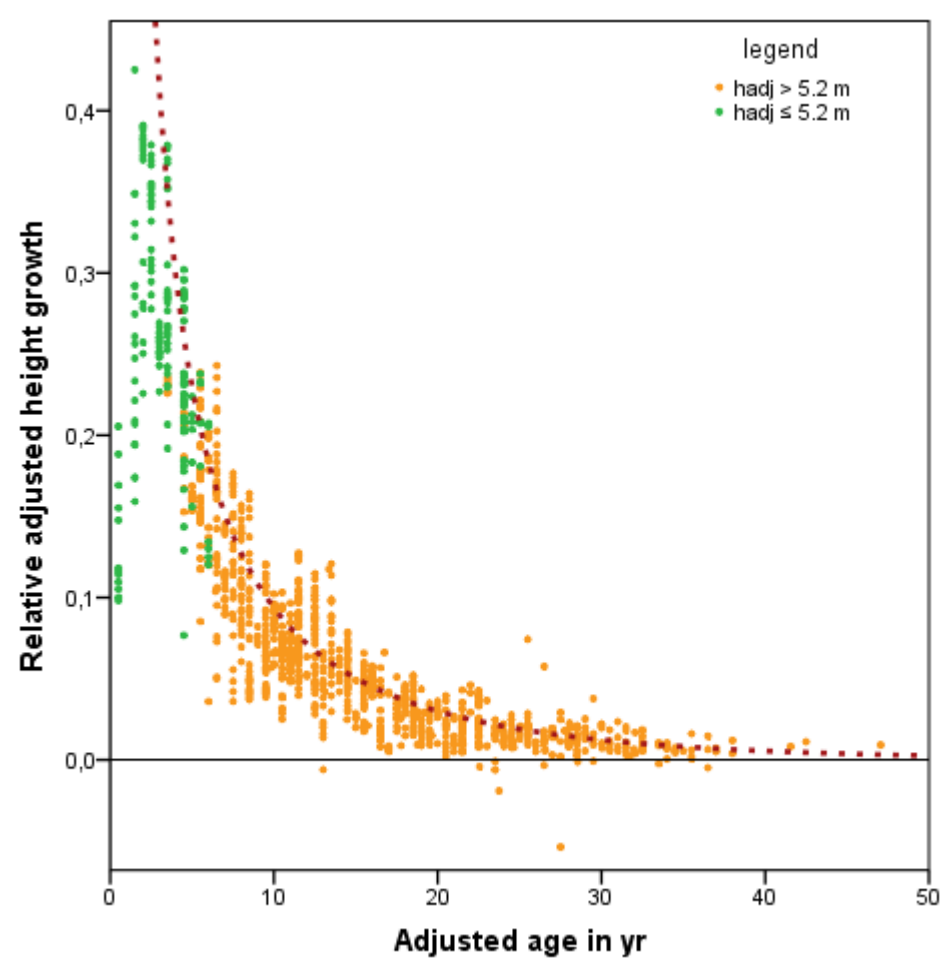

Figuur 4. Relatieve hoogtegroei als functie van de leeftijd. Negatieve waarden duiden op topsterfte of meetfouten. De gearceerd donkerrode lijn geeft de beste fit met het Chapman-Richard model weer.

Figure 4. Relative height increment as a function of age. Negative values can be a die-back situation or regards to measuring errors. The dashed dark red line represents the best fit with Chapman-Richards's model

De criteria van Pagina 12 zijn in een Multi criteria-analyse met gelijk gewicht meegenomen (naar Jansen et al., 2018a). In Tabel 4 zijn de resultaten weergegeven van de regressieanalyse van de opperhoogte met de besproken modellen. In de bovenste helft van Tabel 4 de absolute waarde voor de criteria opgenomen. In het onderste deel van de tabel is de volgorde van resultaat (beste $=1$ en slechtste is 5 ) gegeven (1.5 is gedeelde $1^{\mathrm{e}}$ en $2^{\mathrm{e}}$ plaats). 
Tabel 4. Resultaten van niet-lineaire regressie met de geselecteerde modellen in de MCA. Table 4. Results of nonlinear regression for the selected models in MCA.

\begin{tabular}{|c|c|c|c|c|c|c|c|c|c|c|}
\hline & model & $n_{p a r}^{1)}$ & $R^{2}$ adj & $C V$ & $h_{25}$ & $s$ & $\boldsymbol{h}_{\text {if }}$ & Par-s' & Par-r ${ }^{3)}$ & result \\
\hline \multirow{5}{*}{$\frac{\tilde{y}}{\frac{2}{T}}$} & Chapman-Richards & 2 & 0.986 & $2\{1 ; 4\}$ & $24\{17 ; 31\}$ & $30\{21 ; 39\}$ & $5\{4 ; 7\}$ & + & + & 1 \\
\hline & Burkhart \& Tennent & 3 & 0.986 & $3\{1 ; 6\}$ & $24\{16 ; 31\}$ & $31\{19 ; 42\}$ & $5\{3 ; 7\}$ & + & - & 4 \\
\hline & Jansen \& Hildebrand & 3 & 0.986 & $3\{1 ; 5\}$ & $24\{16 ; 31\}$ & $33\{20 ; 41\}$ & $5\{2 ; 7\}$ & + & - & 2 \\
\hline & Jansen et al. & 4 & 0.984 & $3\{1 ; 5\}$ & $24\{17 ; 31\}$ & $30\{20 ; 39\}$ & $5\{4.6\}$ & + & - & 3 \\
\hline & Cieszewski & 3 & 0.986 & $2\{1 ; 4\}$ & $23\{16 ; 29\}$ & $34\{24 ; 43\}$ & $6\{4 ; 8\}$ & - & - & 5 \\
\hline \multirow{6}{*}{ 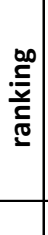 } & Chapman-Richards & 2 & 4 & 1.5 & 1.5 & 1 & 2 & 2.5 & 1 & 13.5 \\
\hline & Jansen \& Hildebrand & 3 & 1 & 3.5 & 3.5 & 3 & 3 & 2.5 & 3.5 & 20 \\
\hline & Jansen et al. & 4 & 5 & 3.5 & 1.5 & 2 & 4 & 2.5 & 3.5 & 22 \\
\hline & Burkhart \& Tennent & 3 & 2 & 5 & 3.5 & 4 & 1 & 2.5 & 3.5 & 21.5 \\
\hline & Cieszewski & 3 & 3 & 1.5 & 5 & 5 & 5 & 5 & 3.5 & 28 \\
\hline & best score & & $\max$ & $\min$ & $24\{17 ; 31\}$ & $<37$ & $5.2\{3 ; 8\}$ & + & + & \\
\hline
\end{tabular}

1) Aantal model parameters exclusief de 193 boniteit parameters voor ieder proefperk.

2) Parameter significantie: + : alle significant, 0 : ingestelde parameters, - : één of meer niet significant

3) Parameter relevantie: + : alle relevant, - : één of meer niet relevant (negatieve waarde)

Het Chapman-Richards model komt als beste uit de MCA, gevonden werd $a=0.0748$ en $b=$ 1.3921 met een $R^{2}$ adj van 0.986 en een standaardafwijking van $96 \mathrm{~cm}$. In alle andere heteromorfe modellen leidde de parameter-combinatie juist tot minder divergentie bij de jeugdgroei, en zijn daarom niet nader onderzocht.

Stap 2. Effect dichtheid of hoogteontwikkeling.

Faber (1985) stelt dat de hoogtegroei van bos ook beïnvloed wordt door de dichtheid, en dat dit in het bijzonder bij klonen van belang is. Faber laat een figuur zien voor het Nelderproefveld 308 met de cultivar Rap met de waarnemingen tot 11 jaar. Deze figuur is nu opnieuw getekend (Figuur 5) tot en met de laatste opname. Tot ongeveer 6 jaar is er voordeel van de beschuttende werking in het zeer dichte plantverband van cirkel $1\left(N_{0}=6441\right)$, bij 24 jaar is er vanaf cirkel $7\left(N_{0}=246\right)$ geen invloed meer van de plantdichtheid. 


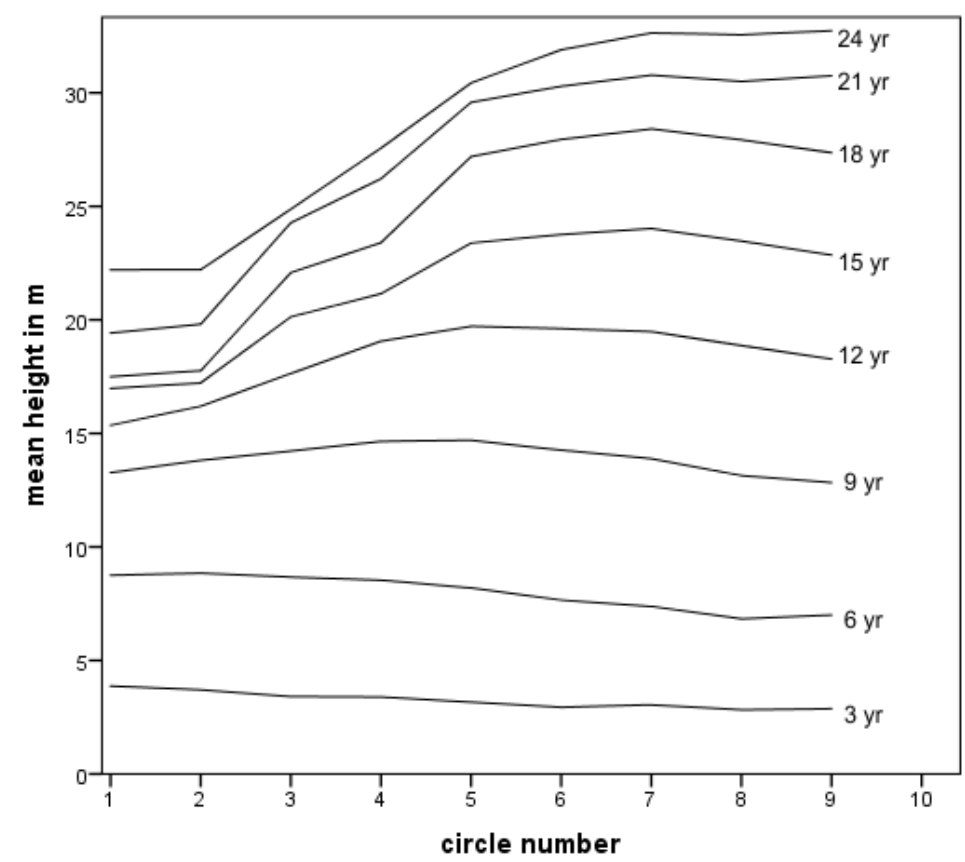

Figuur 5. Hoogte per leeftijd in de 9 opeenvolgende cirkels van Nelder-plot 308.

Figure 5. Height per age in the nine successive circles in Nelder plot 308.

Het achterblijven van de hoogteontwikkeling in de zeer dichte stand heeft mogelijk ook te maken met de keuze voor de gemiddelde hoogte als maat voor de opstandhoogte. Ter illustratie zijn wat vergelijkbare gegevens gezocht voor de douglas in de dataset "FEM growth and yield data Monocultures - Douglas fir" (Schoonderwoerd et al., 2016). Omdat in het Nelderproefveld Harderbos alle boomhoogten gemeten zijn kan hier ook de opperhoogte berekend worden. In Tabel 5 is te zien dat deze definitie wel degelijk invloed heeft, maar de verschillen bij de hoogte blijken bij de populier toch aanzienlijk groter.

Een tweede reden voor de verschillen is ongetwijfeld de geringe variatie in afmetingen bij klonen ten opzichte vanuit zaad opgegroeid plantsoen. De variatiecoëfficiënt van de gemeten hoogte bij populier in alle opnamen blijkt gemiddeld 0.066 , voor de douglas is dat 0.155 dus 2.3 maal zo groot.

Tabel 5. Vergelijking populier en douglas bij ongeveer gelijke boomafstand ( $s p)$.

Table 5. Comparison of poplar and Douglas fir at approximately equal spacing ( $s p)$.

\begin{tabular}{|l|l|rrrr|}
\hline Proefperk & boomsoort & $\boldsymbol{t}$ in $\mathbf{~ r r}$ & $\boldsymbol{s p}$ in $\mathbf{~}$ & $\boldsymbol{h}_{\boldsymbol{m}} / \boldsymbol{h}_{\boldsymbol{g}}$ in $\mathbf{~}$ & $\boldsymbol{h}_{\text {top }}$ in $\mathbf{~}$ \\
\hline Harderbos 3 & populier & 24 & 3.82 & 22.21 & 26.00 \\
Harderbos 6 & populier & 24 & 5.37 & 31.90 & 32.82 \\
\hline Grevenhout B1 & douglas & 67 & 3.44 & 26.08 & 32.17 \\
Grevenhout L2 & douglas & 67 & 5.37 & 32.84 & 34.96 \\
\hline
\end{tabular}

In Figuur 6 is het verloop van de hoogteontwikkeling bij de 9 cirkels van het Nelderproefveld te zien. ledere cirkel is door Faber (1985) als een afzonderlijk proefperk opgevat en in deze studie is deze werkwijze gevolgd. Statistisch is dit niet verantwoord omdat de proefperken 
dan niet meer onderling onafhankelijk zijn. Daarnaast gaat het om maar één rij bomen per proefperk, zodra een boom sterft in een cirkel, verandert niet alleen de gemiddelde boomafstand in het betreffende proefperk, maar ook in die van de ernaast gelegen proefperken. Maar het geeft wel de mogelijk de fenomenen te duiden en te kwantificeren, uitspraken over de bijbehorende nauwkeurigheid zijn niet hard te maken.

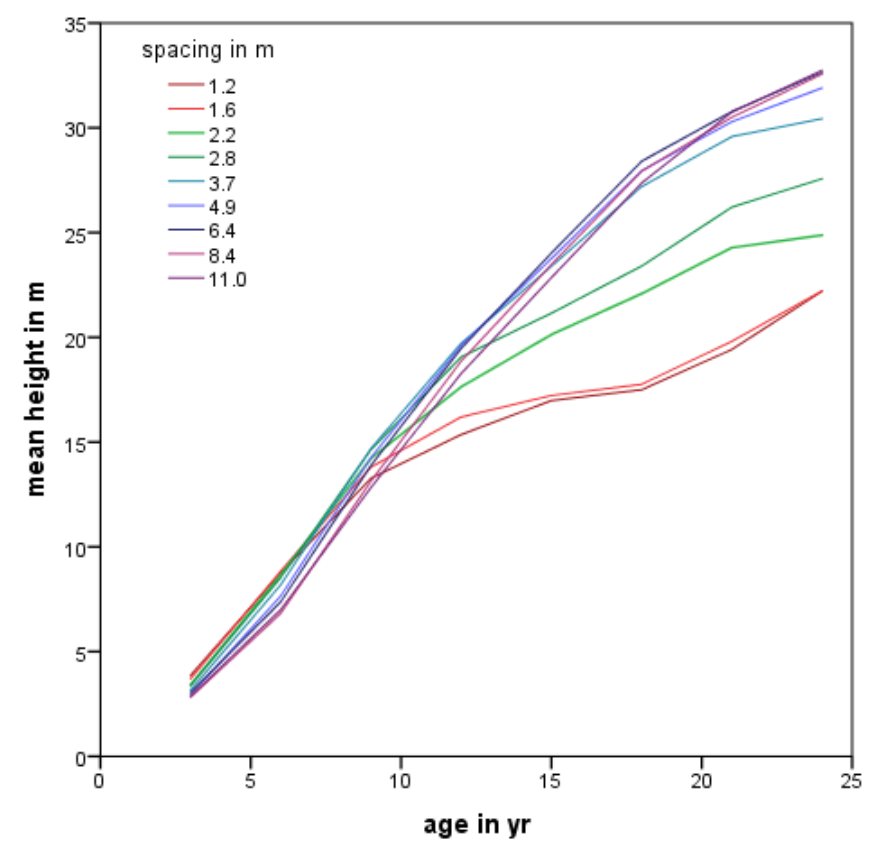

Figuur 6. Hoogte als functie van de leeftijd per cirkel van Nelder-plot 308, van iedere cirkel is in de legenda de oorspronkelijke plantafstand vermeld.

Figure 6. Height as a function of the age per circle of Nelder plot 308, of each plot circle the original spacing is given in the legend.

De drie buitenste cirkels blijken tot 24 jaar een min of meer gelijke hoogteontwikkeling te hebben. De natuurlijke groeiplaatsomstandigheden zijn in het gehele proefveld bij benadering hetzelfde en er mag dus eenzelfde boniteit worden verondersteld. Modelmatig zal dan de $S$-waarde voor het hele proefveld hetzelfde zijn. Maar de met model (5) gevonden de $S$ waarden blijken flink te verschillen, namelijk van 29 tot $39 \mathrm{~m}$. Dit kan worden opgelost door dezelfde $S$-waarde te forceren voor alle 9 cirkels waarbij de beide parameters $a$ en $b$ per cirkel (proefperk) zullen verschillen. Het proefveld P308 omvat de proefperken 108 tot en met 116. Er zijn nog 2 andere Nelder proefvelden en nog 2 andere proefveldcomplexen met plantafstandproeven, in totaal zijn er dan 5 groepen en een restgroep. Hierdoor moet formule (5) als volgt worden aangepast: 


$$
\begin{aligned}
h_{a d j}=\sum_{i \in G_{0}} \operatorname{cor} \cdot S_{i} \cdot x_{i} \cdot\left(1-e^{-a \cdot t_{a d j}}\right)^{b}+\sum_{k=1}^{5}\left\{\sum_{i \in G_{k}} \operatorname{cor} \cdot S_{k} \cdot x_{i} \cdot\left(1-e^{-a \cdot t_{a d j}}\right)^{b}\right\} \\
\text { where cor }=f_{1}(\text { spacing }) \text { and } b=f_{2}(\text { spacing }) \\
G_{1}=\text { group 1, plots } 108-116 \\
G_{2}=\text { group 2, plots } 117-119 \\
G_{3}=\text { group 3, plots } 120-122 \\
G_{4}=\text { group 4, plots } 123-128 \\
G_{5}=\text { group 5, plots } 129-134 \\
G_{0}=\text { group 0, other plots } 1-107,135-156 \text { and } 199-203
\end{aligned}
$$

Met een vereenvoudigde weergave van S luidt Formule (12):

$$
\begin{aligned}
& h_{a d j}=\operatorname{cor} \cdot S \cdot\left(1-e^{-a \cdot t_{a d j}}\right)^{b} \\
& \text { where } c o r= \begin{cases}1 & \text { for plots with thinning } \\
1 & \text { for plots without thinning and } s p_{0} \geq c_{0} \\
1-c_{s p} \cdot\left(c_{0}-s p_{0}\right) & \text { for plots without thinning and } s p_{0}<c_{0}\end{cases} \\
& b= \begin{cases}b_{0} & \text { for plots with thinning } \\
b_{0} & \text { for plots without thinning and } s p_{0} \geq c_{0} \\
b_{0}-b_{s p} \cdot\left(c_{0}-s p_{0}\right) & \text { for plots without thinning and } s p_{0}<c_{0}\end{cases} \\
& s p_{0}=\text { the initial spacing }
\end{aligned}
$$

De $R^{2}$ adj stijgt daardoor licht maar blijft afgerond 0.986, alle parameters zijn significant en de gevonden $S$-waarden zijn gemiddeld 29.8 (tussen 17.5 en 39.3).

\section{Stap 3. Verschillen tussen de cultivars en lijnbeplanting versus bos}

Model (13) is te herschrijven tot:

$$
\begin{aligned}
& h_{a d j}=\operatorname{cor} \cdot S \cdot\left(1-e^{-a \cdot t_{a d j}}\right)^{b} \\
& \text { where cor }= \begin{cases}1 & \text { for plots with thinning } \\
1 & \text { for plots without thinning and } s p_{0} \geq c_{0} \\
1-c_{s p} \cdot\left(c_{0}-s p_{0}\right) & \text { for plots without thinning and } s p_{0}<c_{0}\end{cases} \\
& b= \begin{cases}b_{0} & \text { for plots with thinning } \\
b_{0} & \text { for plots without thinning and } s p_{0} \geq c_{0} \\
b_{0}-b_{s p} \cdot\left(c_{0}-s p_{0}\right) & \text { for plots without thinning and } s p_{0}<c_{0}\end{cases} \\
& a=a_{r} \cdot x_{r}+\sum_{j=1}^{k} a_{j} \cdot \operatorname{var}_{j}
\end{aligned}
$$




$$
\begin{aligned}
& b_{0}=b_{r} \cdot x_{r}+\sum_{j=1}^{k} b_{0 j} \cdot \text { var }_{j} \\
& \text { var }_{j}= \begin{cases}1 & \text { for the } j^{\text {th }} \text { variety } \\
0 & \text { else }\end{cases} \\
& x_{r}= \begin{cases}1 & \text { for roadside plot } \\
0 & \text { else }\end{cases} \\
& s p_{0}=\text { the initial spacing }
\end{aligned}
$$

Alle parameters waren significant Maar de $(a, b)$-parametercombinaties van de verschillende variëteiten sloten elkaar niet alle onderling uit (zie Figuur 7). De $R^{2}$ adj van het model steeg naar 0.995 met een standaarddeviatie van $59 \mathrm{~cm}$.

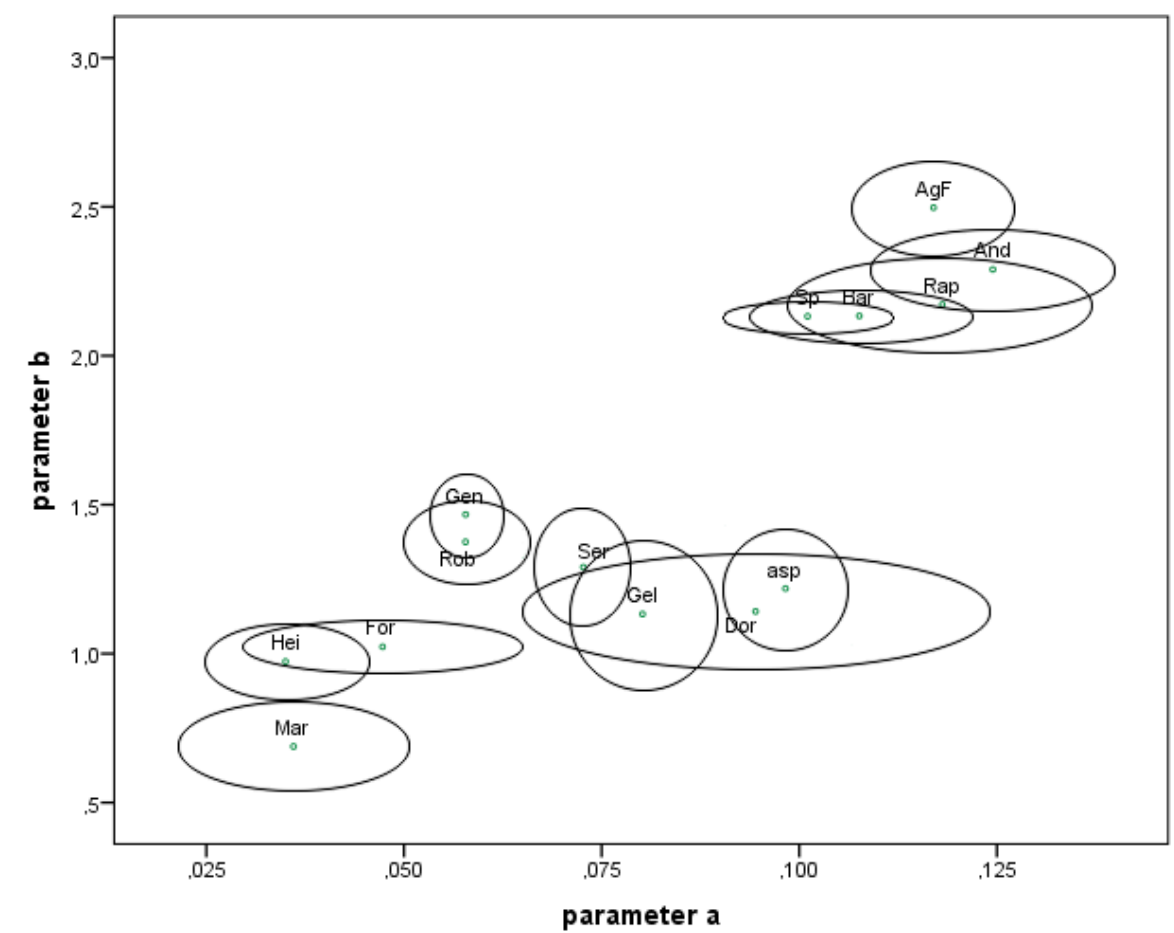

Figuur 7. Betrouwbaarheidsellipsen van parametercombinatie $a$ en $b$ voor de populierenvariëteiten. AgF = 'Agatha F', And = 'Androscoggin', asp = Populus tremula, Bar = 'Barn', Dor = 'Dorskamp', Gel = 'Gelrica', Gen = 'Geneva', Hei = 'Heidemij', For = 'Forndorf', Rob = 'Robusta', Ser = 'Serotina', Mar = 'Marilandica', Rap = 'Rap' en $S p=$ 'Spijk'.

Figuur 7. Confidence ellipses of parameter combination $a$ and $b$ for the Poplar varieties. Where AgF = 'Agatha F', And = 'Androscoggin', asp = Populus tremula, Bar = 'Barn', Dor = 'Dorskamp', Gel = 'Gelrica', Gen = 'Geneva', Hei = 'Heidemij', For = 'Forndorf', Rob = 'Robusta', Ser = 'Serotina', Mar = 'Marilandica', Rap = 'Rap' en Sp = 'Spijk'.

Met behulp van Figuur 7 bleken er vijf groepen te onderscheiden (zie Tabel 6 voor de groepen).

Door in model (14) de groepen in plaats van de variëteiten in te voeren volgt: 


$$
\begin{gathered}
h_{a d j}=\text { cor } \cdot S \cdot\left(1-e^{-a \cdot t_{a d j}}\right)^{b} \\
\text { where cor, } b \text { and } x_{r} \text { are the same as in Formula } 15 \\
\qquad a=\sum_{j=1}^{5} a_{j} \cdot g r_{j}+a_{r} \cdot x_{r} \text { and } b_{0}=\sum_{j=1}^{5} b_{j} \cdot g r_{j}+b_{r} \cdot x_{r} \\
g r_{j}= \begin{cases}1 & \text { for the } j^{\text {th }} \text { group } \\
0 & \text { else }\end{cases}
\end{gathered}
$$

De $R^{2}$ adj van het model daalt naar 0.994 met een standaarddeviatie van $62 \mathrm{~cm}$.

Alle groepen hebben dus dezelfde parameter $a$ en een verschillende parameter $b$. De gemiddelde $S$-waarde blijft nagenoeg gelijk, maar het maximum stijgt met ca. $3 \mathrm{~m}$. Deze waarden liggen alle in de groep Barn voor plots niet ouder zijn dan 12 jaar, dus geen echte onderbouwing voor de S-waarde.

Tabel 6. Groepen met gelijke $b_{0}$ parameter in Model (15).

Table 6. Groups with equal $b_{0}$ parameter in Model (15).

\begin{tabular}{|ll|ll|}
\hline Groep & Cultivar/Soort naam & $\boldsymbol{a}$ & $\boldsymbol{b}_{\mathbf{0}}$ \\
\hline 1 Marilandica & Marilandica & 0.0360 & 0.6886 \\
2 Forndorf & Forndorf en Heidemij & 0.0360 & 1.0144 \\
3 Robusta & Robusta en Geneva & 0.0360 & 1.4075 \\
4 Serotina & Serotina, Gelrica, Dorskamp en esp & 0.0360 & 1.0092 \\
5 Barn & Barn, Agatha F, Rap, Spijk en Androscoggin & 0.0360 & 2.2833 \\
\hline
\end{tabular}

De groepen onderscheiden zich wat betreft de hoogtegroei van elkaar gedurende in ieder geval gedurende de eerste 15 jaar en behalve voor groep 5 is er ook voldoende materiaal om tot 50 jaar boniteringscurven te maken.

Het praktisch nut ervan is echter gering omdat bij bosinventarisatie de cultivar meestal onbekend is of indien wel bekend ook vaak tot een cultivar behoort die niet in de lijst staat. Dat geldt echter niet voor de esp (Populus tremula). Voor het maken van een algemeen groeimodel worden 2 groepen (esp versus de kloon-variëteiten) onderscheiden. Omdat er maar 8 proefperken met esp zijn, waarvan 4 in één proefveldcomplex, is de onderbouwing van de parameter-waarden is gering. Omdat we met esp met een andere soort te maken is de met Formule (3) geïntroduceerde aangepaste hoogte en leeftijd voor de esp niet zinvol en zijn de waarden van $h_{0}$ en $t_{0}$ overal op 0 gesteld.

Stap 4. Verschillen tussen regio's

Een hulpvariabele voor de regio West (bij populier voornamelijk Flevoland) in het model leverde significante verschillen op tussen de $a$ en $b$ parameters in de onderscheiden gebieden 
De correlatie tussen de 5 groepen uit stap 3 en de regio's bleek te groot, waardoor de mogelijk te groot was dat er geen regionale verschillen maar opnieuw verschillen tussen de variëteiten werden geïntroduceerd (zie Tabel 7). Er is daarom afgezien van het opnemen van regionale verschillen.

Tabel 7. Verdeling variëteit-groepen over de regio's.

Table 7. Distribution variety groups on the regions.

\begin{tabular}{|l|rrrrr|r|}
\hline \multirow{2}{*}{ Groep } & \multicolumn{5}{|c|}{ Regio's } & \\
\cline { 2 - 6 } & Noord & Midden & Zuid & West & onbekend & Totaal \\
\hline Marilandica & & 12 & 248 & & 67 & 327 \\
Forndorf & 105 & 29 & 45 & & & 179 \\
Robusta & 38 & 66 & 23 & 399 & & 526 \\
Serotina & & 87 & 90 & 150 & 3 & 330 \\
Barn & & & & 301 & & 301 \\
\hline Totaal & 143 & 194 & 406 & 850 & 70 & 1663 \\
\hline
\end{tabular}

\subsection{Het uiteindelijke model voor de hoogtegroei}

Het geleidelijk opbouwen van het model heeft geleid tot vergelijking (16). In deze en alle volgende vergelijkingen die onderdeel van het opbrengstmodel vormen worden de parameters genummerd als $c_{1}, c_{2}, c_{3}$ enzovoorts.

$$
\begin{gathered}
h_{m}=h_{0}+\text { cor } \cdot S \cdot\left\{1-e^{-c_{1} \cdot\left(t-t_{0}\right)}\right\}^{b} \\
\text { where cor }= \begin{cases}1 & \text { for plots with thinning } \\
1 & \text { for plots without thinning and } s p_{0} \geq c_{5} \\
1-c_{4} \cdot\left(c_{5}-s p_{0}\right) & \text { for plots without thinning and } s p_{0}<c_{5}\end{cases} \\
\qquad \begin{array}{ll}
c_{2} & \text { for plots with thinning } \\
c_{2} & \text { for plots without thinning and } s p_{0} \geq c_{5} \\
c_{2}-c_{3} \cdot\left(c_{5}-s p_{0}\right) & \text { for plots without thinning and } s p_{0}<c_{5}
\end{array} \\
\qquad s p_{0}=\text { the initial spacing; } c_{1} \text { till } c_{5} \text { are the estimated model parameters } \\
h_{0} \text { and } t_{0} \text { are respectively the height and age of the cuttings, } \\
\text { if those values are unknown } h_{0}=1.5 \mathrm{~m} \text { and } t_{0}=2 \mathrm{yr} \\
\text { and for Aspen: } h_{0}=0 \mathrm{~m} \text { and } t_{0}=0 \mathrm{yr}
\end{gathered}
$$

De waarden van de parameters staan in tabel 8. 
Tabel 8. Parameters voor hoogtegroeimodel (16).

Table 8. Parameters for height growth model (16).

\begin{tabular}{|c|c|c|c|c|c|c|c|}
\hline \multirow{2}{*}{$R^{2}$} & \multirow{2}{*}{$R^{2}$ adj } & \multirow{2}{*}{ RMSE } & \multirow{2}{*}{ Parameter } & \multirow{2}{*}{ Estimate } & \multirow{2}{*}{ Standard Error } & \multicolumn{2}{|c|}{ 95\% Confidence Interval } \\
\hline & & & & & & Lower Bound & Upper Bound \\
\hline \multirow{8}{*}{0.988} & \multirow{8}{*}{0.987} & \multirow{8}{*}{0.91} & $C_{1 \text { forest }}$ & 0.0793 & 0.002 & 0.076 & 0.083 \\
\hline & & & $C_{1 \text { roadside }}$ & 0.0523 & 0.003 & 0.046 & 0.058 \\
\hline & & & $c_{\text {1aspen }}$ & 0.1126 & 0.008 & 0.096 & 0.129 \\
\hline & & & $c_{2 \text { forest }}$ & 1.4745 & 0.025 & 1.426 & 1.523 \\
\hline & & & $C_{2 \text { roadside }}$ & 1.0339 & 0.042 & 0.951 & 1.117 \\
\hline & & & $c_{3}$ & 0.1396 & 0.021 & 0.099 & 0.180 \\
\hline & & & $c_{4}$ & 0.1474 & 0.015 & 0.118 & 0.176 \\
\hline & & & $c_{5}$ & 3.3087 & 0.152 & 3.011 & 3.606 \\
\hline
\end{tabular}

Voor het gebruik in de praktijk (zonder de dichte stand en de kennis betreffende steklengte en stekleeftijd) is het model veel eenvoudiger:

$$
h_{m}= \begin{cases}1.5+S \cdot\left\{1-e^{-c_{1} \cdot(t-2)}\right\}^{c_{2}} & \text { for poplar varieties } \\ S \cdot\left\{1-e^{-c_{1} \cdot t}\right\}^{c_{2}} & \text { for aspen }\end{cases}
$$

\subsubsection{Analyse van de residuen}

In Figuur 8 is de voorspelde hoogte tegen de waargenomen hoogte uitgezet, er is sprake van een zeer geringe doch niet significante onzuiverheid.

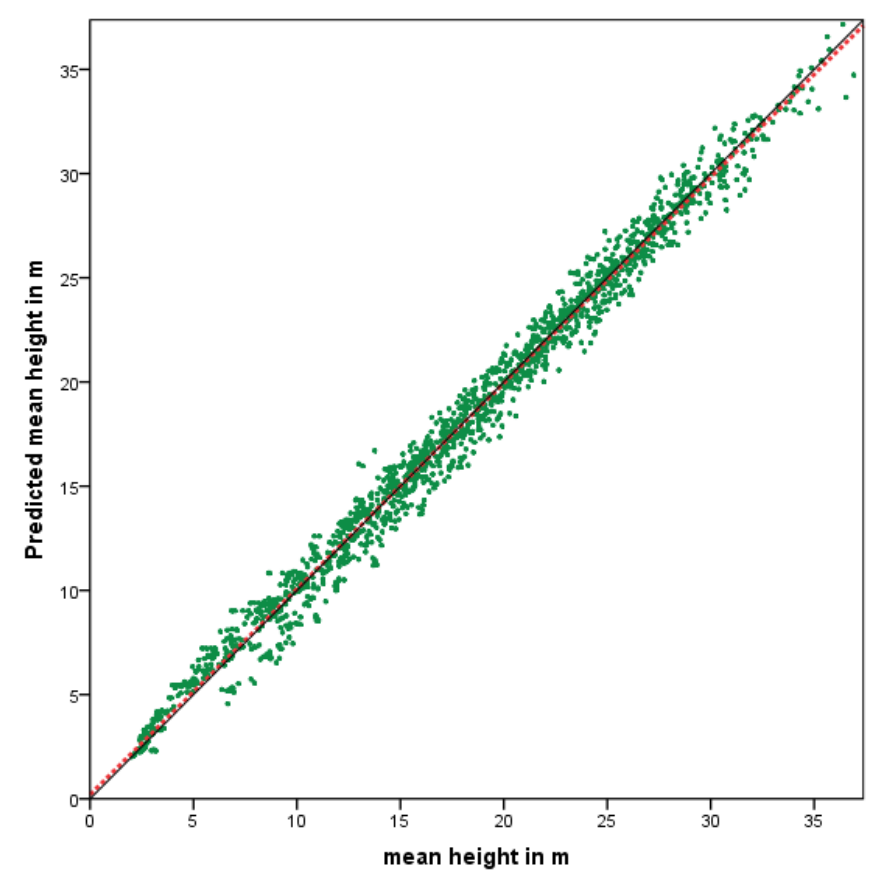

Figuur 8. Voorspelde hoogte met Formule (16) in relatie met gemeten hoogte. De rode lijn geeft lineaire fit weer, de zwarte lijn geeft de perfecte fit weer.

Figure 8. $\quad$ Predicted height with model (16) in relation with observed height at recording time. The red line represents the linear fit, the black line the perfect fit. 
De gestandaardiseerde residuen van Model (16) zijn uitgezet tegen de systeemvariabele leeftijd in Figuur 9.

Er zijn 4 uitbijters met een relatieve afwijking van meer dan $3 \sigma$ ten opzichte van de gemodelleerde hoogte, een verklaring werd niet gevonden.
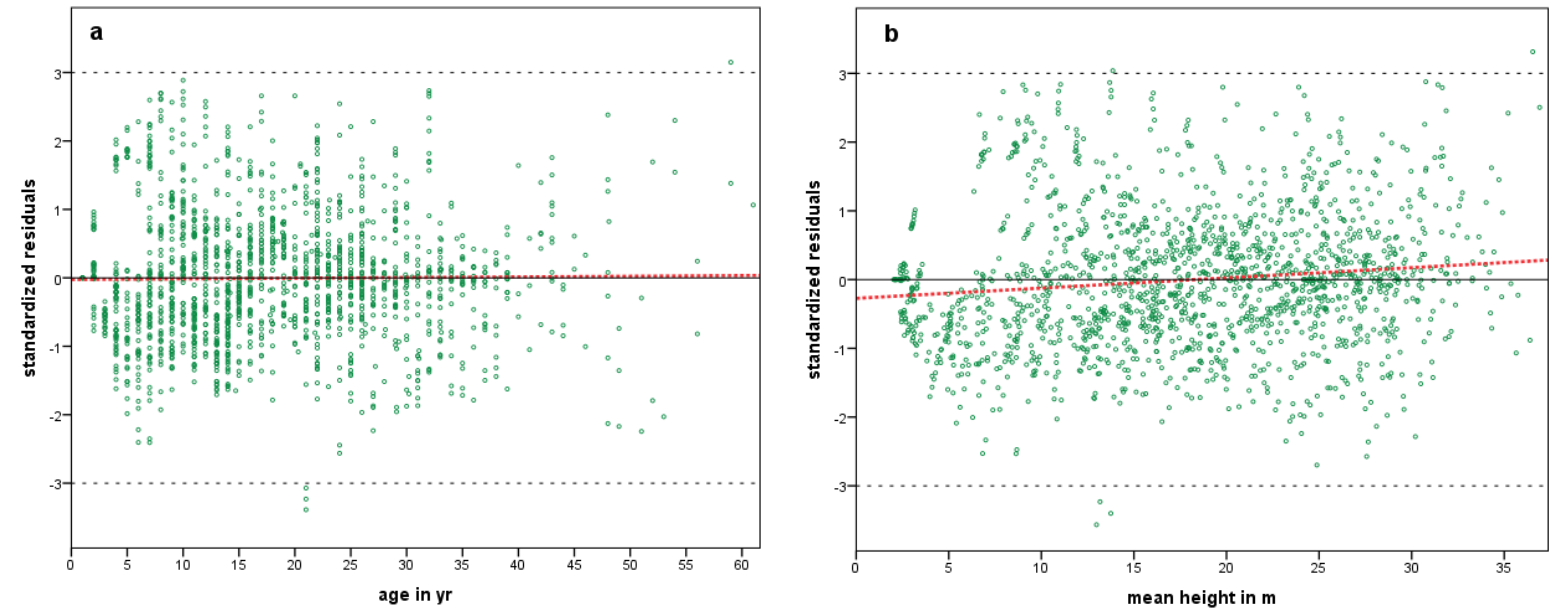

Figuur 9. Gestandaardiseerde residuen van model 16 en de variabele leeftijd (a) en hoogte (b). De rode lijn is de lineaire fit door de puntenwolk.

Figure 9. Standardized residuals in relation to age (a) and height (b), the red line is the linear fit.

Een bron van de geringe onzuiverheid in relatie tot hoogte zou kunnen liggen in het verschil per kloon, zoals blijkt uit Figuur 10. De "oude" variëteiten hebben gemiddeld een hogere gemiddelde hoogte per opname dan bij de "nieuwe" variëteiten en op twee uitzonderingen (Dorskamp en Oxford) lopen de afwijkingen van de voorspelde hoogte daarmee in de pas.
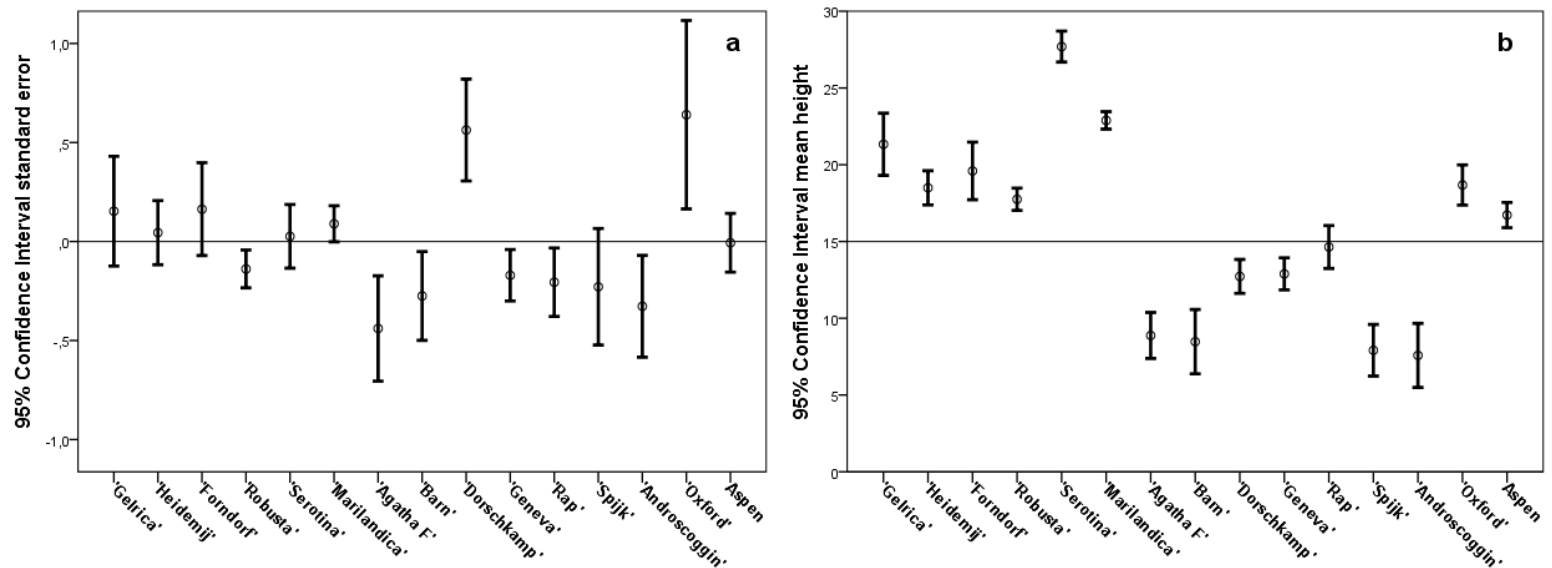

Figuur 10. Betrouwbaarheidsinterval residuen van Model (16) per variëteit of soort in Figuur 10a en het betrouwbaarheidsinterval van de gemiddelde hoogte per varieteit of soort in Figuur $10 \mathrm{~b}$.

Figure 10. Confidence interval of residues of Model (16) per variety or species (a) and the confidence interval of the mean height per variety or species (bo. 


\subsubsection{Boniteitindeling}

De met model (16) gevonden waarden van $S$ voor de proefperken in bos liggen tussen 17.4 en 39.1. Met de gegevens van de $4^{\mathrm{e}}$ Bosstatistiek (CBS, 1985) is van 5385 monocultures met populier de $h_{25}$ bepaald volgens de methode van Jansen et al. (2016).

Uit de formules (3) en (16) volgt:

$$
h_{25}=h_{0}+S \cdot\left\{1-e^{-a \cdot\left(25-t_{0}\right)}\right\}^{b}
$$

where $a$ and $b$ are functions of the initial spacing (see Formula 16)

De met het geparametriseerde model (17) berekende $h_{25}$ ligt tussen de 14.9 en $32.3 \mathrm{~m}$, maar $95 \%$ ligt tussen 18.4 en $32.3 \mathrm{~m}$. De gemiddelde $h_{25}$ bedraagt $26.1 \mathrm{~m}$. Op basis van dit interval is een boniteitindeling met 5 relatieve boniteiten ontworpen met intervallen van $3.4 \mathrm{~m}$ tussen de grenzen 16.5 en 33.5 m (zie tabel 9a).

Tabel 9a. Indeling in boniteiten gebaseerd op de $\boldsymbol{h}_{25}$ (exclusief lijnbeplantingen en esp).

Table 9a. Classification in site classes based on the $h_{25}$ (excluding line plantations and aspen).

\begin{tabular}{|c|r|r|r|r|r|}
\hline Relatieve Boniteit & S-waarde & $\boldsymbol{h}_{25}$ & Bereik $\boldsymbol{h}_{25}$ & \% in data set & \% in 4e bosstatistiek \\
\hline$<$ I & & & & & 2.5 \\
I & 39.28 & 31.8 & $(30.1-33.5)$ & 18.2 & 8.5 \\
II & 34.87 & 28.4 & $(26.7-30.1)$ & 15.6 & 21.9 \\
III & 30.46 & 25.0 & $(23.3-26.7)$ & 49.1 & 33.8 \\
IV & 26.06 & 21.6 & $(19.9-23.3)$ & 13.0 & 20.0 \\
V & 21.65 & 18.2 & $(16.5-19.9)$ & 3.9 & 10.9 \\
$>$ V & & & & 0.2 & 2.5 \\
\hline
\end{tabular}

Het bovenstaande leidt tot de procentuele verdeling over de boniteiten voor Nederland zoals weergegeven in de laatste kolom van tabel 9. Daarin heeft $2.5 \%$ van de opstanden een boniteit $\mathrm{VI}$ of slechter en $2.5 \%$ een boniteit $\mathrm{O}$ of beter. Modelmatig zijn deze boniteiten niet toegevoegd, omdat dit een te sterke extrapolatie buiten het basismateriaal betreft.

In de $4^{\mathrm{e}}$ bosstatiek is wel een aparte code lijnbeplantingen gebruikt, maar hoogte en kiemjaar zijn meestal onbekend, daarom is de gevolgde procedure niet mogelijk. Op grond van Tabel $9 \mathrm{~b}$ en de ligging in Figuur 11b, zijn 5 boniteiten onderscheiden.

Tabel $9 b$. Indeling in boniteiten gebaseerd op de $\boldsymbol{h}_{25}$ voor lijnbeplantingen.

Table $9 \mathrm{~b} . \quad$ Classification in site classes based on the $h_{25}$ for line plantations.

\begin{tabular}{|l|c|c|c|r|}
\hline Relatieve Boniteit & $\boldsymbol{S}$-waarde & $\boldsymbol{h}_{25}$ & Bereik $\boldsymbol{h}_{25}$ & \multicolumn{1}{c|}{ \% in data set } \\
\hline I & 39.37 & 28.7 & $(27.2-30.2)$ & 3.9 \\
II & 35.03 & 25.7 & $(24.2-27.2)$ & 20.2 \\
III & 30.68 & 22.7 & $(21.2-24.2)$ & 42.6 \\
IV & 26.34 & 19.7 & $(18.2-21.2)$ & 28.4 \\
V & 22.00 & 16.7 & $(15.2-18.2)$ & 5.0 \\
\hline
\end{tabular}


Voor trilpopulier is in Tabel 9c en Figuur 11 rechts tevens het controle plot H0660 en 4 plots uit het MFV (Dirkse, 2007) opgenomen. Dit betreffen de plotnummers 33344, 69457, 69714 en 77854 .

Tabel 9c. Indeling in boniteiten gebaseerd op de $\boldsymbol{h}_{25}$ voor trilpopulier.

Table 9c. Classification in site classes based on the $h_{25}$ for aspen.

\begin{tabular}{|l|c|c|c|r|r|}
\hline Relatieve Boniteit & S-waarde & $\boldsymbol{h}_{\mathbf{2 5}}$ & Bereik $\boldsymbol{h}_{\mathbf{2 5}}$ & \% in data set & Plots in MFV \\
\hline I & 22.34 & 20.4 & $19.1-21.7)$ & 13.9 & \\
II & 19.50 & 17.8 & $(16.5-19.1)$ & 50.0 & 1 \\
III & 16.65 & 15.2 & $(13.9-16.5)$ & 25.0 & 1 \\
IV & 13.80 & 12.6 & $(11.3-13.9)$ & 0.0 & 11.1 \\
V & 10.95 & 10.0 & $(8.7-11.3)$ & \\
\hline
\end{tabular}

In Figuur 11a is de hoogteontwikkeling per boniteit samen met die van de proefperken in bos weergegeven, in $11 \mathrm{~b}$ die van de lijnbeplantingen en $11 \mathrm{c}$ die van trilpopulier. Let op! Voor de vergelijking is alle figuren dezelfde schaal gebruikt, dat is niet de schaal van de uiteindelijke boniteringsfiguren.
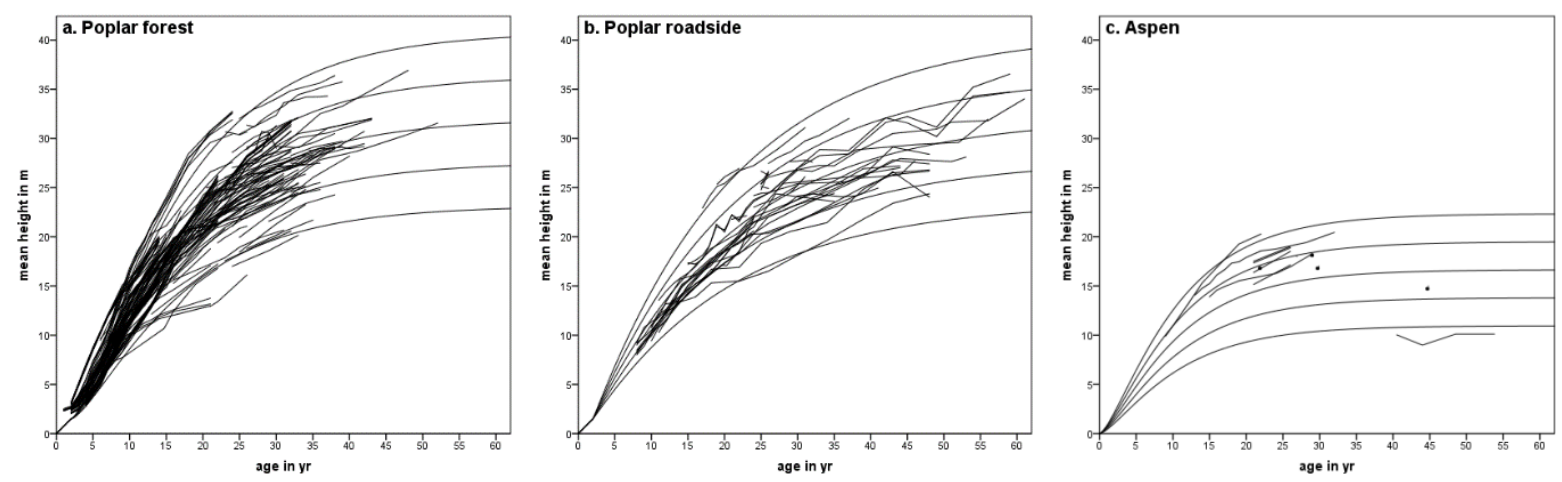

Figuur 11. Hoogteontwikkeling van de proefperken en boniteitcurven voor populieren-klonen in bos (a), in lijnbeplantingen (b) en voor trilpopulier (c).

Figure 11. Height development of plots site curves for poplar clones in forest (a), for line plantations (b) and for aspen (c).

\subsection{Toetsing model met controle plots}

Door de gevonden parameters van tabel 8 te fixeren in model (16) zijn daarna voor de 42 HOSP plots van de controle-set de $S$-waarden geschat. Daarmee zijn de residuen berekend, in formule:

$$
y_{i j}=h_{m_{i j}}-\hat{h}_{16_{i j}}
$$

where $\hat{h}_{16_{i j}}$ the predicted $h_{m}$ with Formula 16 for the $j^{\text {th }}$ record in the $i^{\text {th }}$ plot 

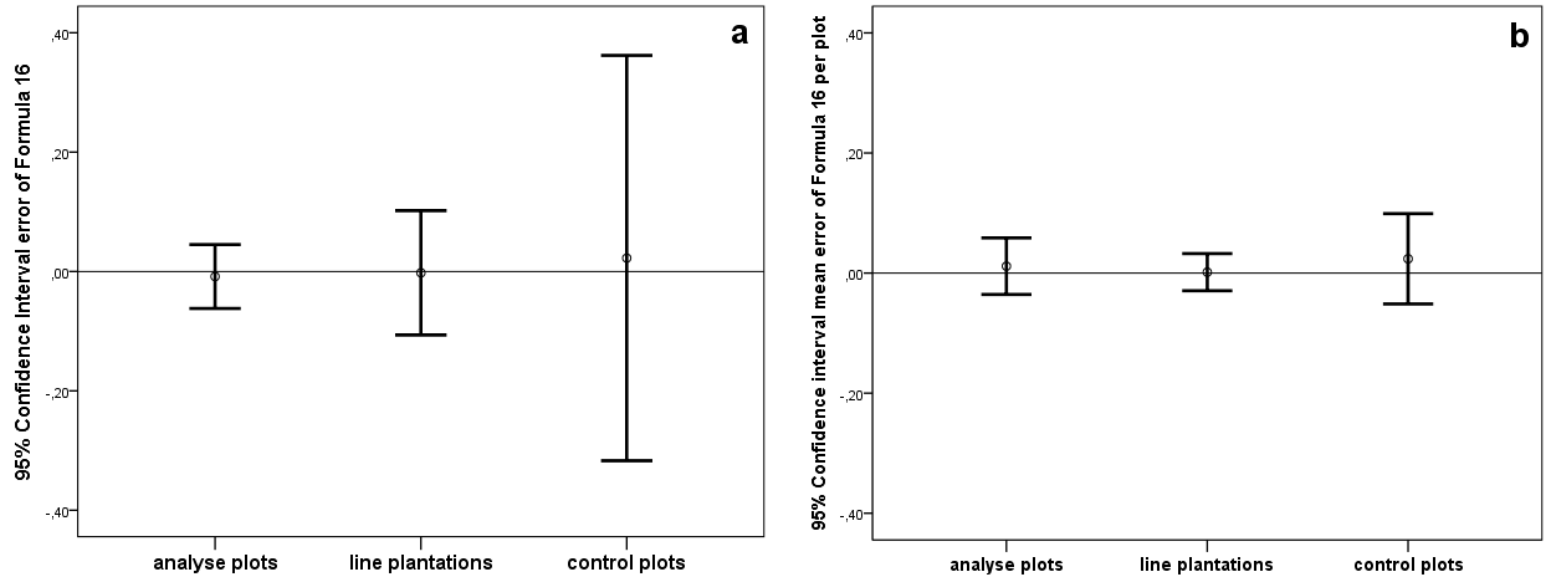

Figuur 12. Betrouwbaarheidsinterval residuen van model (16) voor de analyse plots, plots in lijnbeplantingen en de controle plots op opname-niveau(a) en op gemiddeld plot-niveau (b).

Figure 12. Confidence interval of the residuals from model (16) for the groups analysis plots, line plantations and control plots (a) and the 95\% confidence interval of the average of those residuals per plot (b).

In Figuur $12 \mathrm{a}$ is te zien dat die residuen niet verschillen per opname tussen de analyse plots, de lijn beplantingen en de controle plots. Wel bleek er geheel volgens de verwachting een HOSP-effect op de standaarddeviatie van die afwijkingen (in Figuur 12a te zien aan het veel ruimere betrouwbaarheidsinterval bij de controle plots). De opnamen van de HOSP plots zijn immers niet meegenomen in de analyse omdat door enerzijds de kleine oppervlakte en anderzijds het meten van de hoogte in meters in plaats van decimeters een grotere variantie werd verondersteld. Ook de gemiddelden van de residuen per plot bleken niet significant te verschillen in een variatieanalyse, zie Figuur $11 \mathrm{~b}$ en Tabel 10. Dit betekent dat de controleplots goed aansluiten bij het gevonden model. Het niet-significante verschil bedroeg ruim 1 centimeter. De controleplots van de HOSP-studie sluiten dus zeer goed aan bij het gevonden model, dat geldt ook voor de weg- en grensbeplantingen van populier.

Tabel 10. ANOVA van HOSP-effect op de gemiddelde residuen per plot.

Table 10. ANOVA of HOSP effect on the average residuals per plot.

\begin{tabular}{|l|r|r|r|r|l|}
\hline & Sum of Squares & \multicolumn{1}{c|}{ df } & Mean Square & F & \multicolumn{1}{l|}{ Sig. } \\
\hline Between Groups & 0.007 & 1 & 0.007 & 0.090 & 0.764 \\
Within Groups & 17.290 & 233 & 0.074 & & \\
Total & 17.297 & 234 & & & \\
\hline
\end{tabular}

\subsection{Conclusie model hoogtegroei}

Het beste model voor de hoogteontwikkeling dat aan de voorwaarden (zie Pagina 12) voldoet is het model van Chapman-Richards, in de uiteindelijke Formule (16) speelt plantafstand als er niet gedund wordt ook een rol. Voor de lijnbeplantingen en voor trilpopulier werden aparte parameter-sets gevonden. De boniteit wordt als een relatieve boniteit gepre- 
senteerd met een daarbij behorende hoogte op 25 -jarige leeftijd. Bij 2.5 procent van de populierenopstanden in Nederland is de boniteit beter dan boniteit I, en ook heeft $2.5 \%$ een lagere boniteit dan de hier gepresenteerde slechtste boniteit V (Tabel 9a). Het materiaal leent zich echter niet voor verdere extrapoleren. De groei bij de lijnbeplantingen verschilt van die in bossen en hier zijn aparte boniteringscurven voor gemaakt. Dat was ook mogelijk voor bepaalde groepen van variëteiten, dat is niet uitgevoerd, omdat het nut ervan gering is. Wel zijn aparte boniteringscurven voor de trolpopulier gemaakt.

Ongedunde bosopstanden met een plantafstand onder de $3.3 \mathrm{~m}$ ondergaan een gereduceerde hoogtegroei. In lijnbeplantingen komt die reductie niet voor, ongetwijfeld omdat de groeiruimte loodrecht op de rij niet beperkt is.

Het ontwikkelde model blijkt uitstekend te passen bij de controle-set met de HOSP-plots. 


\section{Opbrengstniveau}

Naast de hoogtegroei (hoofdstuk 3) vindt ook diktegroei plaats. Dit resulteert in diameterbijgroei $i_{d}=\left(d_{2}-d_{1}\right) /\left(t_{2}-t_{1}\right)$ en een grondvlakbijgroei $i_{G}=\left(G_{2}-G_{1}\right) /\left(t_{2}-t_{1}\right)$. Hoogtegroei en diktegroei tezamen resulteren in een volumebijgroei $i_{v}=\left(V_{2}-V_{1}\right) /\left(t_{2}-t_{1}\right)$. In opbrengsttabellen is een belangrijk doel juist deze volumebijgroei te bepalen. Aangezien het boomvolume in de dataset een afgeleide, berekende variabele is en niet berust op een primaire waarneming, zal ook de bijgroei van het volume indirect worden berekend.

De diameter en het totale grondvlak zullen in de loop van de tijd toenemen, maar gelijktijdig neemt ook de hoogte toe. Voor de hand liggende variabelen om de diameter en het grondvlak te verklaren zijn dus leeftijd en opperhoogte. Dat geldt ook voor de bijgroei zelf. Na het bereiken van de borsthoogte vormen bomen zeer brede jaarringen, die daarna geleidelijk in dikte afnemen. Aangezien op goede standplaatsen de omslag van dikke naar smallere jaarringen op jongere leeftijd plaats vindt dan op slechte standplaatsen, speelt ook de boniteit een rol. Maar er is ook veel interactie tussen de drie variabelen boniteit, leeftijd en hoogte. Verder is de standruimte uiteraard van belang voor de diktegroei. Deze komt tot uitdrukking in het stamtal of gemiddelde boomafstand.

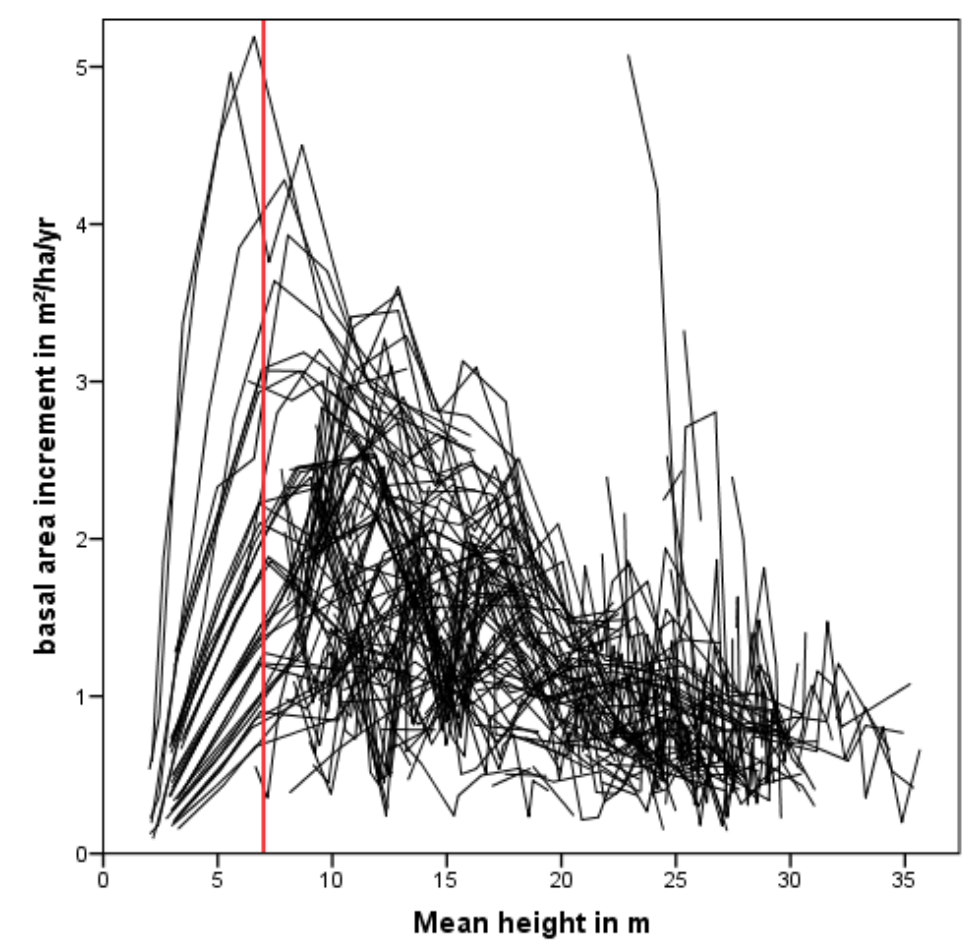

Figuur 13. Grondvlakbijgroei per proefperk als functie van hoogte.

De grondvlakbijgroei neemt eerst toe ten opzichte van zowel de hoogte (zie Figuur 13) als de leeftijd, en daarna weer af. Jansen et al. (2016) gebruiken die hoogtegrens bij douglas in hun modellen als grens tussen de modellen. In het traject van stijgende groei (en zonder dunning) tot een hoogte van $7 \mathrm{~m}$ wordt de diameterontwikkeling gemodelleerd. In Paragraaf 4.1 komt dit aan de orde. Voor populier lijkt die grens (Figuur 13) per proefperk te variëren tussen een hoogte van 5 en $10 \mathrm{~m}$ te liggen en voldoet een grens bij $7 \mathrm{~m}$. 
Voor de ontwikkeling boven een hoogte van $7 \mathrm{~m}$ kan zowel de diameterbijgroei (Paragraaf 4.2.2) als de grondvlakbijgroei (Paragraaf 4.2.1) worden gebruikt, maar ook met een model voor de diameterbijgroei moet uiteindelijk de grondvlakbijgroei worden geschat.

\subsection{Diameterontwikkeling tot een hoogte van $7 \mathrm{~m}$}

Als maat voor de diameter is gekozen voor de "gemiddelde" diameter van de opstand voor dunning $\left(d_{b t}\right)$. Onder "gemiddelde" wordt hier verstaan het kwadratische gemiddelde. Het gaat dus om de $d_{g}$, maar de toevoeging $g$ (van gemiddeld grondvlak) is weggelaten.

Jansen et al. (2016) vonden voor de diameterontwikkeling tot een opperhoogte van $7 \mathrm{~m}$ het volgende Gompertz-model (1832):

$$
\begin{gathered}
d_{b t}=d_{7} \cdot\left\{\frac{\exp \left(-b_{11} \cdot e^{-b_{12} \cdot\left(h_{\text {top }}-1.30\right)}\right)}{\exp \left(-b_{11} \cdot e^{-b_{12} \cdot(7-1.30)}\right)}\right\} \text { for } h \leq 7 \mathrm{~m} \\
\text { where } d_{7}=b_{13}+b_{14} / \sqrt{N_{0}}
\end{gathered}
$$

In de dataset vinden er zelfs geen dunningen plaatst bij een hoogte lager dan $9 \mathrm{~m}$. In Figuur 14 het verloop van de diameterontwikkeling als functie van de gemiddelde hoogte weergegeven tot een hoogte van $7.5 \mathrm{~m}$.

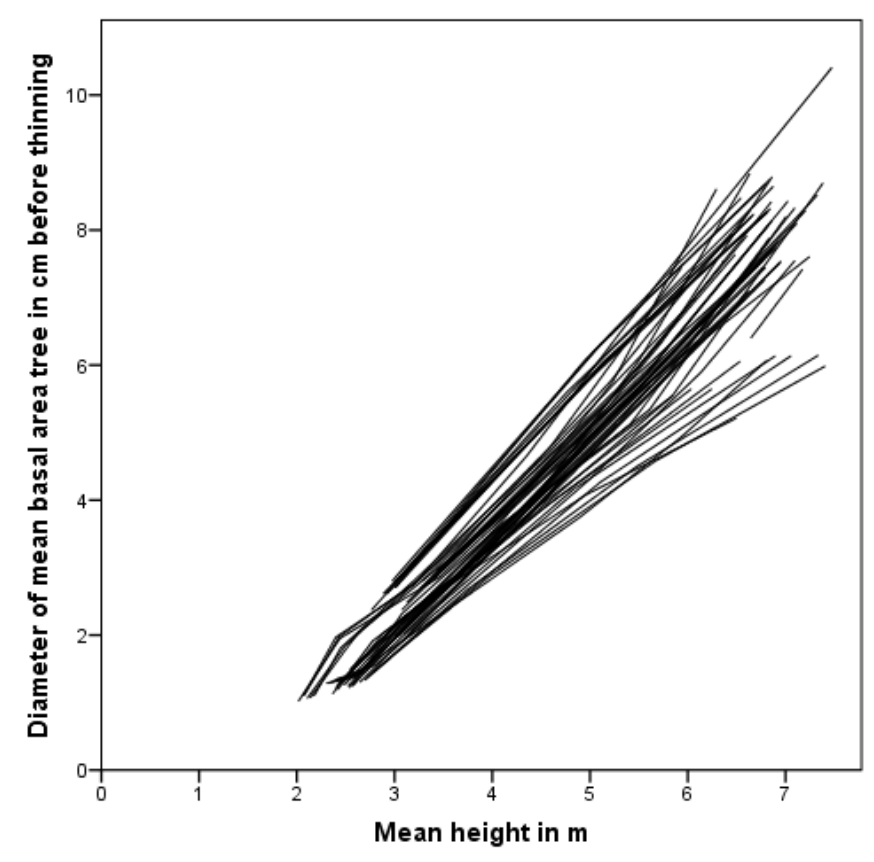

Figuur 14. Verloop van de diameterontwikkeling als functie van hoogte.

Figure 14. Course of the diameter development as a function of height.

Toegepast voor de populier is Formule (19) herschreven tot: 


$$
\begin{gathered}
d_{b t}=d_{7} \cdot\left\{\frac{\exp \left(-c_{9} \cdot e^{-c_{10} \cdot(h-1.30)}\right)}{\exp \left(-c_{9} \cdot e^{-c_{10} \cdot(7-1.30)}\right)}\right\} \text { for } h \leq 7 \mathrm{~m} \\
\text { where } d_{7}=c_{6}+c_{7} \cdot s p_{0} \\
\quad s p_{0}(\text { initial spacing })=10000 / \sqrt{N_{0}}
\end{gathered}
$$

De $R^{2}$ adj bedroeg 0.952. Na een regressiediagnose op de residuen is het model verder aangepast tot:

$$
\begin{gathered}
d_{b t}=d_{7} \cdot\left\{\frac{\exp \left(-c_{9} \cdot e^{-c_{10} \cdot(h-1.30)}\right)}{\exp \left(-c_{9} \cdot e^{-c_{10} \cdot(7-1.30)}\right)}\right\} \text { for } h \leq 7 \mathrm{~m} \\
\text { where } d_{7}=c_{6}+c_{7} \cdot s p_{\max } \\
s p_{\max }= \begin{cases}s p_{0} & \text { for } s p_{0} \leq c_{8} \\
c_{8} & \text { for } s p_{0}>c_{8}\end{cases}
\end{gathered}
$$

Met 193 waarnemingen, een $R^{2}$ adj van 0.961 en met een standaardafwijking van $0.47 \mathrm{~cm}$ werd de oplossing van Tabel 11 gevonden. Aangezien er geen lijnbeplantingen in het traject liggen in niet na te gaan of er verschil in parameter-waarden op dit punt bestaat.

Tabel 11. Parameters voor Model (21)

Table 11. Parameters for Model (21).

\begin{tabular}{|l|r|r|r|r|}
\hline \multirow{2}{*}{ Parameter } & & & \multicolumn{2}{|c|}{ 95\% Confidence Interval } \\
\cline { 4 - 5 } & Estimate & Std. Error & Lower Bound & \multicolumn{1}{c|}{ Upper Bound } \\
\hline$c_{6}$ & 7.2415 & 0.485 & 6.286 & 8.197 \\
$c_{7}$ & 0.9175 & 0.154 & 0.614 & 1.221 \\
$c_{8}$ & 3.8169 & 0.292 & 3.241 & 4.393 \\
$c_{9}$ & 3.1055 & 0.072 & 2.963 & 3.248 \\
$c_{10}$ & 0.3524 & 0.030 & 0.294 & 0.411 \\
\hline
\end{tabular}

In Tabel 12 is het effect van het beginstamtal op de ontwikkeling van de diameter gegeven, indien er tot een hoogte van $7 \mathrm{~m}$ niet gedund wordt.

Tabel 12. Diameter bij $\boldsymbol{h}=\mathbf{7} \mathrm{m}$ bij verschillende plantafstanden.

Table 12. Diameter at $h=7 \mathrm{~m}$ for different spacing..

\begin{tabular}{|rrr|}
\hline $\boldsymbol{N}_{\mathbf{0}}$ & $\boldsymbol{S} \boldsymbol{p}_{\mathbf{0}}$ & $\boldsymbol{d}_{\mathbf{7}}$ \\
\hline $\mathbf{6 8 6}$ & 3.8 & 10.7 \\
1000 & 3.2 & 10.1 \\
2500 & 2.0 & 9.1 \\
\hline
\end{tabular}




\section{Regressiediagnose}

In Figuur 15 is te zien dat er vier uitbijters aanwezig zijn, met een afwijking van meer dan $3 \sigma$, een verklaring werd niet gevonden. De lichte hellinghoek in Figuur $15 \mathrm{~b}$ is niet significant.
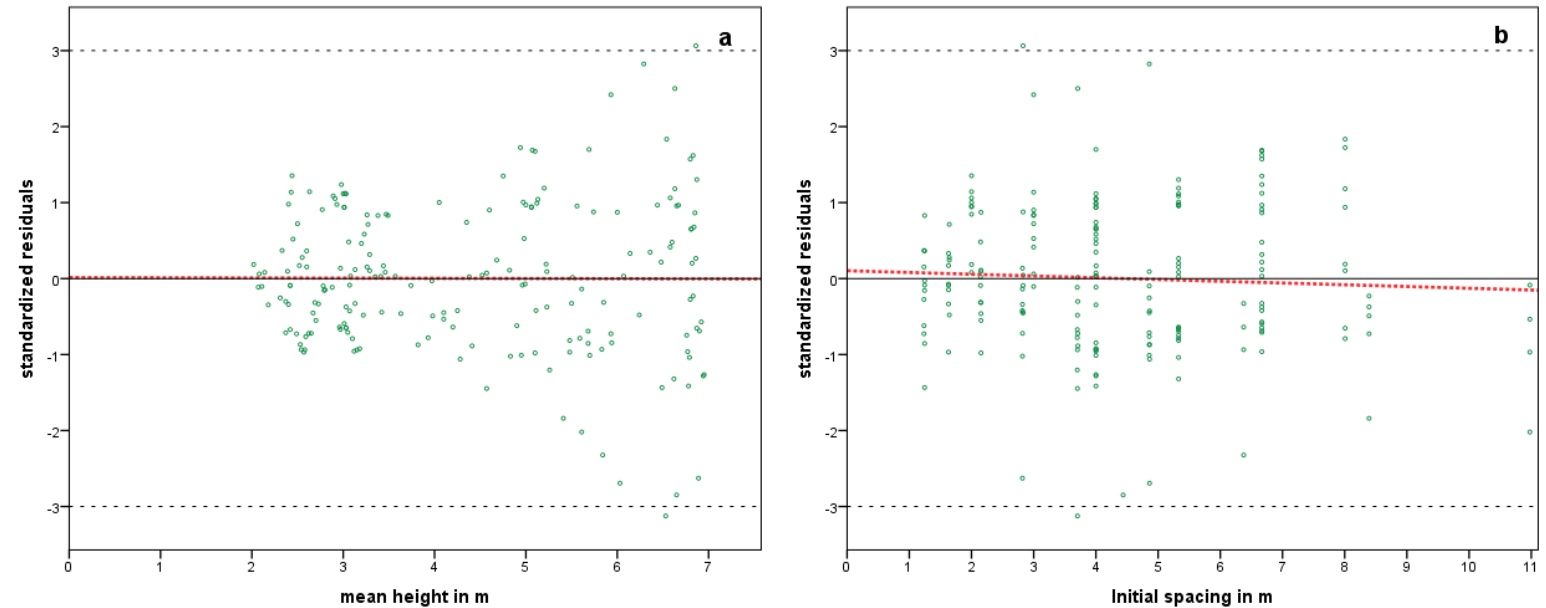

Figuur 15. Gestandaardiseerde residuen van model (21) in relatie tot de modelfactoren hoogte (a) en begin boomafstand (b) met lineaire fit door de residuen.

Figure 15. Standardized residuals of model (21) in relation to height (a) and spacing (b), the red lines represent linear fit.

\section{Conclusie}

Het model dat Jansen et al. (2016) voor de douglas vonden bleek toepasbaar voor de populier, wel moest het effect van de begin-boomafstand beperkt blijven tot een bovengrens. $\mathrm{Er}$ is een nauwkeurige schatter voor de $d_{7}$ (de diameter bij een hoogte van $7 \mathrm{~m}$ ) gevonden. En ook de ontwikkeling van die diameter tot $d_{7}$ kan voorspeld worden.

\subsubsection{Directe schatting grondvlakbijgroei voor hoogte boven de $7 \mathrm{~m}$}

De grondvlakbijgroei betreft een berekende waarneming tussen 2 opnamen, de leeftijd en hoogte betreffen dan het gemiddelde tussen beide opnamen.

Bij de komende analyse zijn de volgende proefperken of opnamen uitgesloten:

- Plotnummer 52, 53 wegens laagdunning in plaats van systematische dunning. De meeste proefperken met trilpopulier hebben ook laagdunning maar worden niet uitgesloten;

- Plotnummer 311 opname 10, wegens negatieve diameterbijgroei, ten gevolge van verschil in meettechniek. Opname 9 met omtrekmeting en opname 10 twee jaar later met overkruis klemming;

- Alle Nelder-proefperken omdat op één na de ontwikkeling in alle cirkels beïnvloed kan zijn door sterfte in de ernaast gelegen cirkel, dat betreffen de plotnummers 108 tot en met 116 en 123 tot en met 134;

- $\quad$ De controle plots van studie 4.

In totaal betreft het 170 proefperken met 1126 opnamen met een hoogte boven $7 \mathrm{~m}$. 
In Figuur 16 is te zien dat de grondvlakbijgroei vanaf een hoogte van $7 \mathrm{~m}$ een monotoon dalende functie met veel ruis op de lijn betreft. Een groot deel van die ruis wordt veroorzaakt door de lijnbeplantingen, zie Figuur 16c ten opzichte van Figuur 16a en Figuur 16d ten opzichte van Figuur 16b. De achterliggende oorzaak is de vrije groeiruimte die bomen in lijnbeplantingen hebben loodrecht op de rij, zowel bovengronds (denk aan wegen met of zonder een rij bomen aan de andere kant van de weg en de afstand tussen die rijen) als ondergronds (denk aan type wegverharding of sloten). Soms zijn lijnbeplantingen oorspronkelijk aangelegd als een singel met meerdere elzen per populier. Al dit soort informatie is echter onvolledig beschikbaar en daardoor niet bruikbaar.
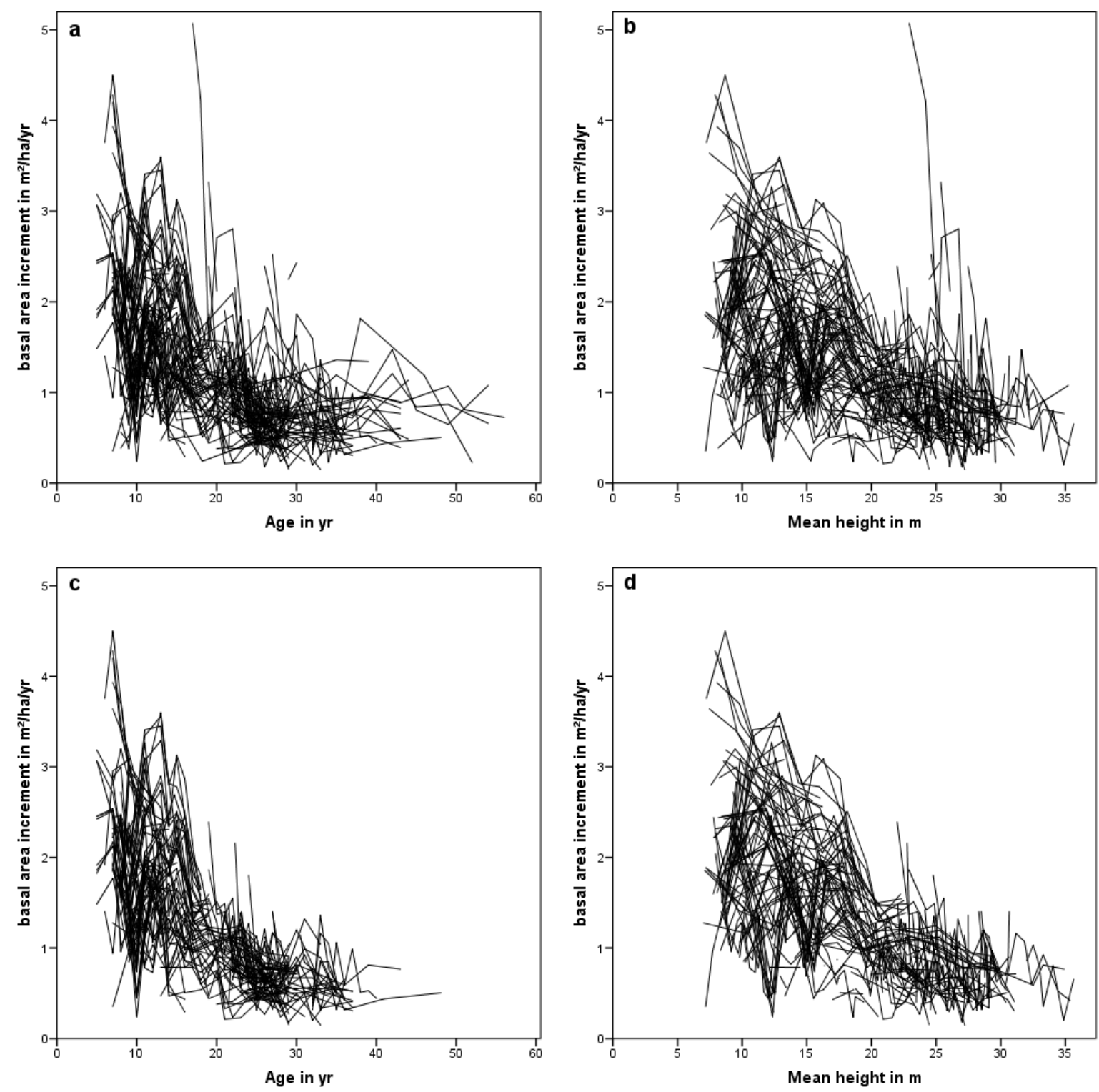

Figuur 16. Grondvlakbijgroei per proefperk als functie van leeftijd (a) en hoogte (b) met alle geselecteerde opnamen en met uitsluiting van de lijnbeplantingen voor leeftijd (c) en hoogte(d)

Figure 16. The basal area increment per plot as a function of age (a) and height (b) for all selected plots and the same figures without the line plantations for age (c) and height (d). 
Jansen et al. (2016) ontwikkelden voor de grondvlakbijgroei van douglas het volgende model:

$$
i_{G, i j k}=Y I_{j} \cdot P L_{k} \cdot f_{1}(S \%) \cdot f_{2}(\text { site }) \cdot \frac{F_{3}\left(t_{2}, h_{2}\right)-F_{3}\left(t_{1}, h_{1}\right)}{t_{2}-t_{1}}
$$

Hierin is $F_{3}$ een power-functie, voor de douglas bleek $f_{2}$ geen significante bijdrage te leveren.

Om te beoordelen of de variëteit rol van betekenis speelt en of er een effect is van lijnbeplanting versus bos is een variantieanalyse uitgevoerd, zie Tabel 13 ( $\left.R^{2} \mathrm{adj}=0.659\right)$. Voor de populier blijkt dat de boniteit wel van belang is, het effect "lijnbeplanting" is van belang, de variëteit speelt een belangrijke rol van betekenis. Jansen et al. (2016) gebruikten in plaats van een jaarindex $(Y I)$ een correctiefactor $c f_{80}$ met een waarde voor opname voor en na 1980. In de variantieanalyse speelt het daaraan gekoppelde effect $x_{80}$ eveneens een rol. Naast de relatieve boomafstand $S \%$, speelt ook de echte boomstand na dunning $s p$ een rol. De variëteit heeft ook een grote invloed op de grondvlakbijgroei, maar die wordt voornamelijk door 2 variëteiten ('Geneva' en 'Androscoggin') veroorzaakt. Met gebruik van alleen deze beide variëteiten en een restgroep daalt $R^{2}$ adj tot 0.625 . Zonder een indeling gebaseerd op variëteiten is $R^{2}$ adj slechts 0.483 .

Tabel 13. Variantieanalyse van de grondvlakbijgroei met mogelijk verklarende variabelen.

Table 13. Analysis of variance with the basal area increment $i_{G}$ explained some variables.

\begin{tabular}{|l|rrrrr|}
\hline Source & Sum of Squares & df & Mean Square & F & Sig. \\
\hline Corrected Model & 393.734 & 19 & 20.723 & 115.324 & 0.000 \\
Intercept & 5.964 & 1 & 5.964 & 33.193 & 0.000 \\
Roadside effect & 7.254 & 1 & 7.254 & 40.369 & 0.000 \\
$X_{80}$ & 1.423 & 1 & 1.423 & 7.918 & 0.005 \\
variety & 105.827 & 12 & 8.819 & 49.078 & 0.000 \\
$h_{25}$ & 38.650 & 1 & 38.650 & 215.087 & 0.000 \\
age & 2.197 & 1 & 2.197 & 12.228 & 0.000 \\
height & 29.956 & 1 & 29.956 & 166.707 & 0.000 \\
spacing & 6.371 & 1 & 6.371 & 35.453 & 0.000 \\
S\% & 21.577 & 1 & 21.577 & 120.075 & 0.000 \\
Error & 198.740 & 1106 & 0.180 & & \\
Total & 2450.671 & 1126 & & & \\
Corrected Total & 592.474 & 1125 & & & \\
\hline
\end{tabular}

Bij nader onderzoek van model (22) voor de populier bleek dat de vervangende correctiefactor $c f_{80}$ voor de jaarindex $Y I$ niet van 1 te verschillen. De functie $f_{2}$ bleek voor populier in tegenstelling tot de douglas wel significante. $F_{3}$ is de functie voor de totale grondvlakproductie, hier voldeed een powerfunctie die zowel naar de hoogte als de leeftijd kan worden gemodelleerd. Voor de douglas bleek de toevoeging van de leeftijd geen extra verklaring te geven, voor populier bleek dat wel het geval. Voor douglas bleek de parameter $c_{17}$ een functie van de hoogte, voor populier niet. De functie $f_{1}$ bestaat bij populier net als bij douglas uit een correctiefactor als functie van het $\mathrm{S} \%$.

Het niet-lineaire regressiemodel voor de populier luidt dan: 


$$
\begin{aligned}
& i_{G}=c_{11} \cdot h_{25}^{c_{12}} \cdot \operatorname{cor}_{5 \%} \cdot\left\{c_{16} \cdot T_{h}+\left(1-c_{16}\right) \cdot T_{t}\right\} \cdot c f_{80} / d t \text { for } h_{1}>7 \\
& \text { where } c o r_{S \%}= \begin{cases}1 & \text { for } S \% \leq c_{14} \\
1-c_{13} \cdot\left(S \%-c_{14}\right)^{c_{15}} & \text { for } S \%>c_{14}\end{cases} \\
& T_{h}=\left(h_{2 c}-1.30\right)^{c_{17}}-\left(h_{1}-1.30\right)^{c_{17}} \text { and } T_{t}=\left(t_{2}-t_{130}\right)^{c_{17}}-\left(t_{1}-t_{130}\right)^{c_{17}} \\
& h_{1} \text { and } h_{2} \text { are the mean heights at time } t_{1} \text { and } t_{2} \\
& h_{2 c}= \begin{cases}h_{2} & \text { for } h_{2}>h_{1} \\
h_{1}+\hat{h}_{2}-\hat{h}_{1} & \text { for } h_{2} \leq h_{1}\end{cases} \\
& \hat{h}_{k}=\text { predicted height with Formula } 17 \text { at time } t_{k} \\
& S \%=\text { Hart Becking spacing index at } t_{1} \text {, see Formula } 1 \\
& c f_{80}=1
\end{aligned}
$$

In model (23) is de borsthoogteleeftijd geschat met $t_{130}=1.30 \cdot t_{0} / h_{0}$.

Met een $R^{2}$ adj $=0.748$ en standaarddeviatie $0.36 \mathrm{~m}^{2} \mathrm{ha}^{-1} \mathrm{jr}^{-1}$ werden aparte waarden voor parameter $c_{11}$ voor 'Geneva', 'Androscoggin' en voor de lijnbeplantingen gevonden, ook de parameters $C_{12}$ en $c_{16}$ verschilden voor de lijnbeplantingen.

Voor trilpopulier werden geen aparte parameters gevonden.

Bij een analyse van de residuen viel het grote verschil tussen de bosplots en de lijnbeplantingen op (zie Figuur 17). Model (23) is daarom ook voor beide groepen apart gedraaid. De $R^{2}$ adj bleek 0.804 standaarddeviatie $0.33 \mathrm{~m}^{2} \mathrm{ha}^{-1} \mathrm{jr}^{-1}$ in bos en 0.427 standaarddeviatie 0.44 $\mathrm{m}^{2} \mathrm{~km}^{-1} \mathrm{jr}^{-1}$ in de lijnbeplantingen. Model (23) bleek dus minder geschikt voor de lijnbeplantingen. In Paragraaf 4.4 zal daarom naar een beter model worden gezocht voor de lijnbeplantingen.

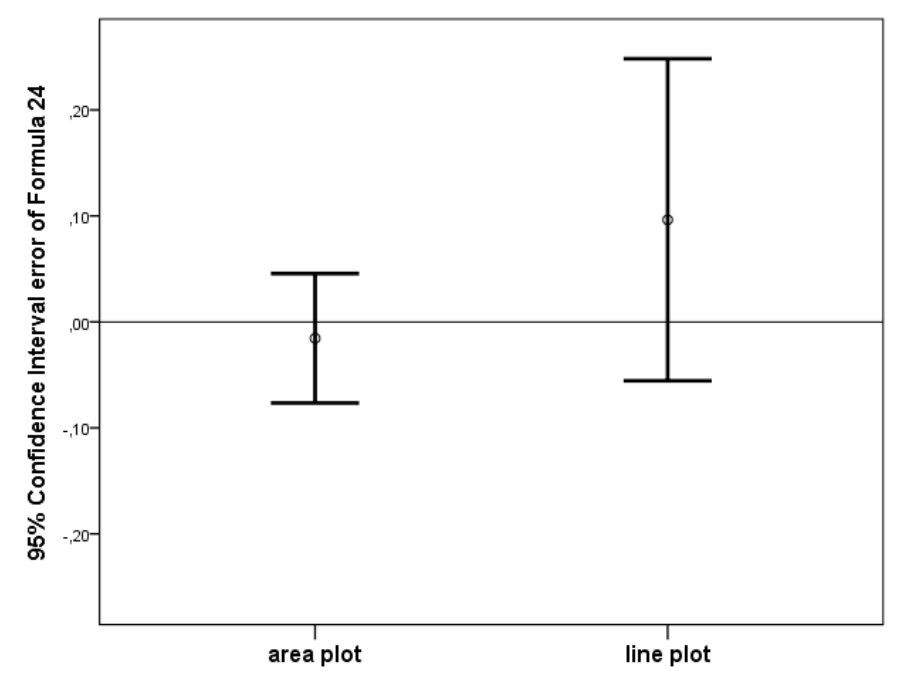

Figuur 17. Betrouwbaarheidsinterval gestandaardiseerde residuen van model (23) voor de plots in bosopstanden en in lijnbeplantingen.

Figure 17. Confidence interval of standardized residuals from model (23) for forest plantations and for line plantations.

In Tabel 14 is de oplossing van Model (23) gegeven voor de 138 plot en 877 opnamen in het bos. 
Tabel 14. Parameterschatting bij Model (23) in bosopstanden.

Tabel 14. Parameter estimation for Model (23) in forest plantations.

\begin{tabular}{|l|r|r|r|r|}
\hline & & & \multicolumn{2}{|c|}{ 95\% Confidence Interval } \\
\cline { 4 - 5 } Parameter & Estimate & Std. Error & Lower Bound & \multicolumn{1}{c|}{ Upper Bound } \\
\hline$c_{11}$ & 3.8077 & 1.123 & 1.604 & 6.011 \\
$c_{12}$ & 0.5218 & 0.080 & 0.365 & 0.679 \\
$c_{13}$ & 0.0230 & 0.007 & 0.010 & 0.037 \\
$c_{14}$ & 29.1240 & 1.547 & 26.088 & 32.160 \\
$c_{15}$ & 0.8324 & 0.076 & 0.683 & 0.982 \\
$c_{16}$ & 0.5537 & 0.023 & 0.509 & 0.599 \\
$c_{17}$ & 0.4031 & 0.027 & 0.350 & 0.456 \\
\hline$c_{11 \text { Geneva }}$ & 6.1361 & 1.770 & 2.667 & 9.605 \\
$c_{11 \text { Androscoggin }}$ & 4.7656 & 1.408 & 2.007 & 7.524 \\
\hline
\end{tabular}

\section{Kwaliteit van het model}

In Figuur 18 is te zien is dat het model lage waarden van de grondvlakbijgroei overschat en de hoge waarden onderschat. Dit heeft te maken met het ontbreken van een verfijnde jaarindex.

In Figuur 19 is te zien dat het model voor de modelvariabelen hoogte (a), leeftijd (b), het S\% (c) en boniteit $h_{25}$ (d) een nagenoeg zuivere schatter geeft, want de lichte hellinghoeken van de lineaire fit door de puntenwolk in de figuren blijken nergens significant. Wel zijn er veel uitbijters zijn die meer dan $3 \sigma$ afwijken. Een algemene verklaring werd niet gevonden.

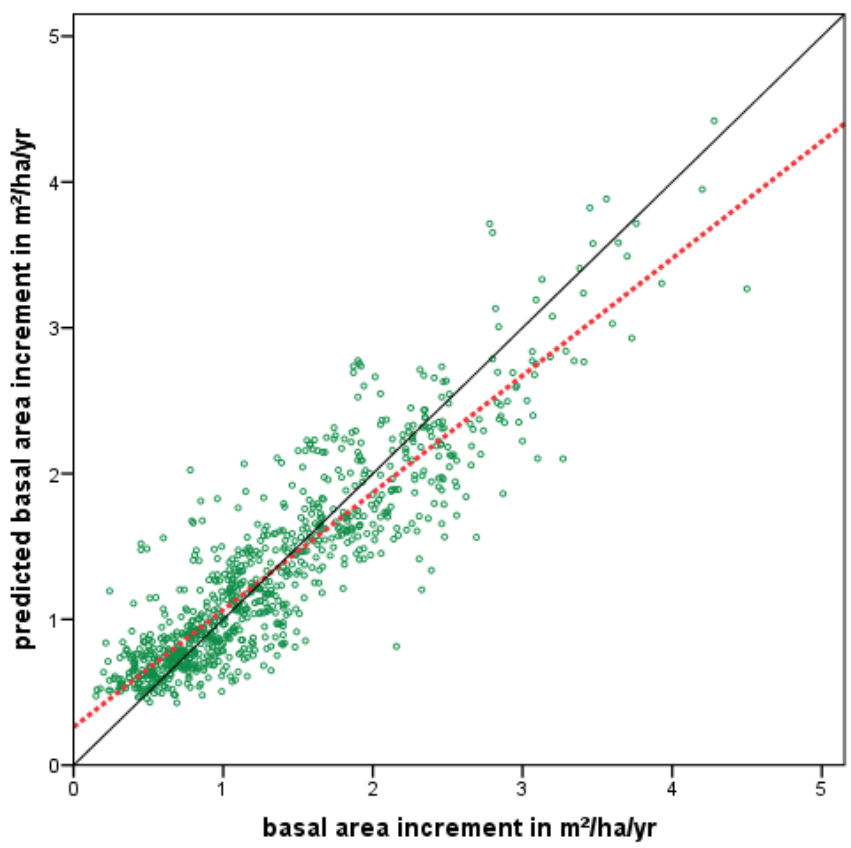

Figuur 18. Voorspelde grondvlakbijgroei als functie van de gemeten grondvlakbijgroei. De zwarte lijn geeft een 1 op 1 verhouding aan; de rode lijn is de lineaire fit door de puntenwolk.

Figure 18. Predicted basal area increment as a function of the measured basal area increment. The black line represents a 1 to 1 relation; the red line is the linear fit through the point cloud. 

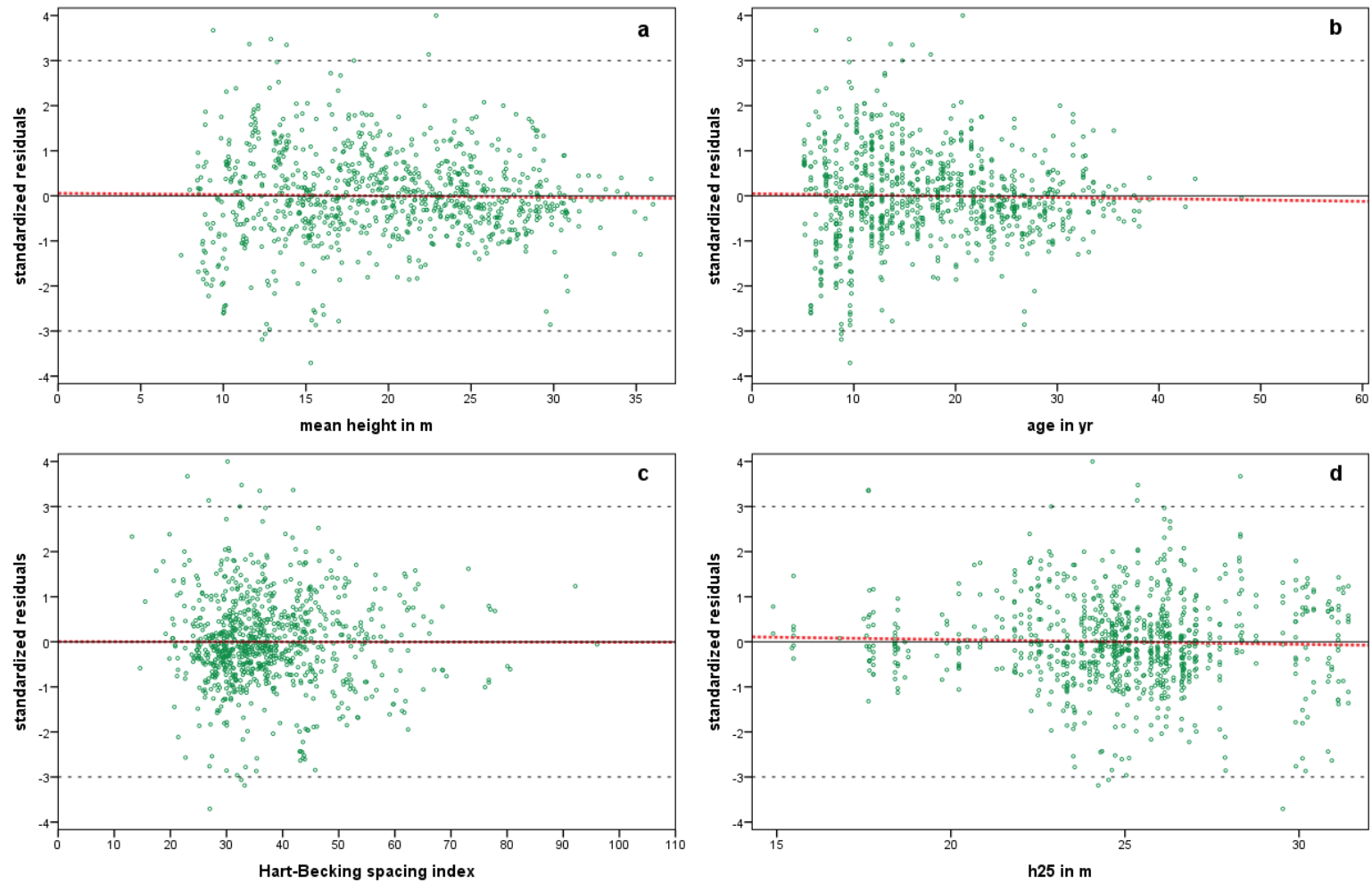

Figuur 19. Gestandaardiseerde residuen van model (23) in relatie tot de modelvariabelen hoogte (a), leeftijd (b), $S \%(c)$ en $h_{25}(d)$. De rode lijn geeft de lineaire regressielijn weer door de residuen.

Figure 19. Standardized residuals of model (23) in relation to the model variables and other variables. The red line shows the linear regression line through the residuals.

Met de parameters uit tabel 14 en model (23) is nu ook bij de controle plots de verwachting en de afwijking berekend. Hierbij is één plots uitgesloten:

- Plotnummer 161, het enige plot met abeel (Populus alba).

De verschillen van de residuen op opnameniveau blijken zijn niet significant (zie tabel 15) tussen beide groepen (analyse en controle plots). Model en parameters blijken toepasbaar voor de controle plots.

Tabel 15. ANOVA van control plot effect op de residuen.

Table 15. ANOVA of control plot effect on the average residuals.

\begin{tabular}{|l|r|r|r|r|c|}
\hline & Sum of Squares & \multicolumn{1}{|c|}{ df } & Mean Square & F & Sig. \\
\hline Between Groups & 1.386 & 1 & 1.386 & 1.420 & 0.234 \\
Within Groups & 886.418 & 908 & 0.976 & & \\
Total & 887.804 & 909 & & & \\
\hline
\end{tabular}

Daarna is met Formule (24) het plotniveau geschat: 


$$
i_{G}=\hat{i}_{G}\left(\text { Formula 24) } \cdot P L_{k} \text { for } h>7 \mathrm{~m}\right.
$$

De plotniveaus van de HOSP-controle plots blijken $8.0 \%$ hoger te liggen, dit verschil is niet significant. De plotniveaus liggen tussen 0.25 en 2.81 , maar $90 \%$ ligt tussen de 0.46 en 1.88 , een verklaring voor die extremen werd niet gevonden. De variëteit en regio bleken enige verklaring voor het plotniveau te geven, maar dit bleek geen nuttige informatie om het model te verbeteren.

\section{Conclusie}

Met het model van Jansen et al. (2016) is de grondvlakbijgroei van bossen te voorspellen, niet alle elementen van het model bleken toepasbaar, en de leeftijd speelde een rol. Voor trilpopulier met laagdunning en voor lijnbeplantingen zijn andere modellen nodig.

\subsubsection{Indirecte schatting grondvlakbijgroei voor hoogte boven de $7 \mathrm{~m}$}

Met dezelfde uiteindelijke selectie zonder de lijnbeplantingen als in paragraaf 4.2.1 is nu de diameterbijgroei geschat en daaruit vervolgens de grondvlakbijgroei.

In Figuur 20 is te zien dat de diameterbijgroei vanaf een hoogte van $10 \mathrm{~m}$ een monotoon dalende functie met veel ruis op de lijn betreft.
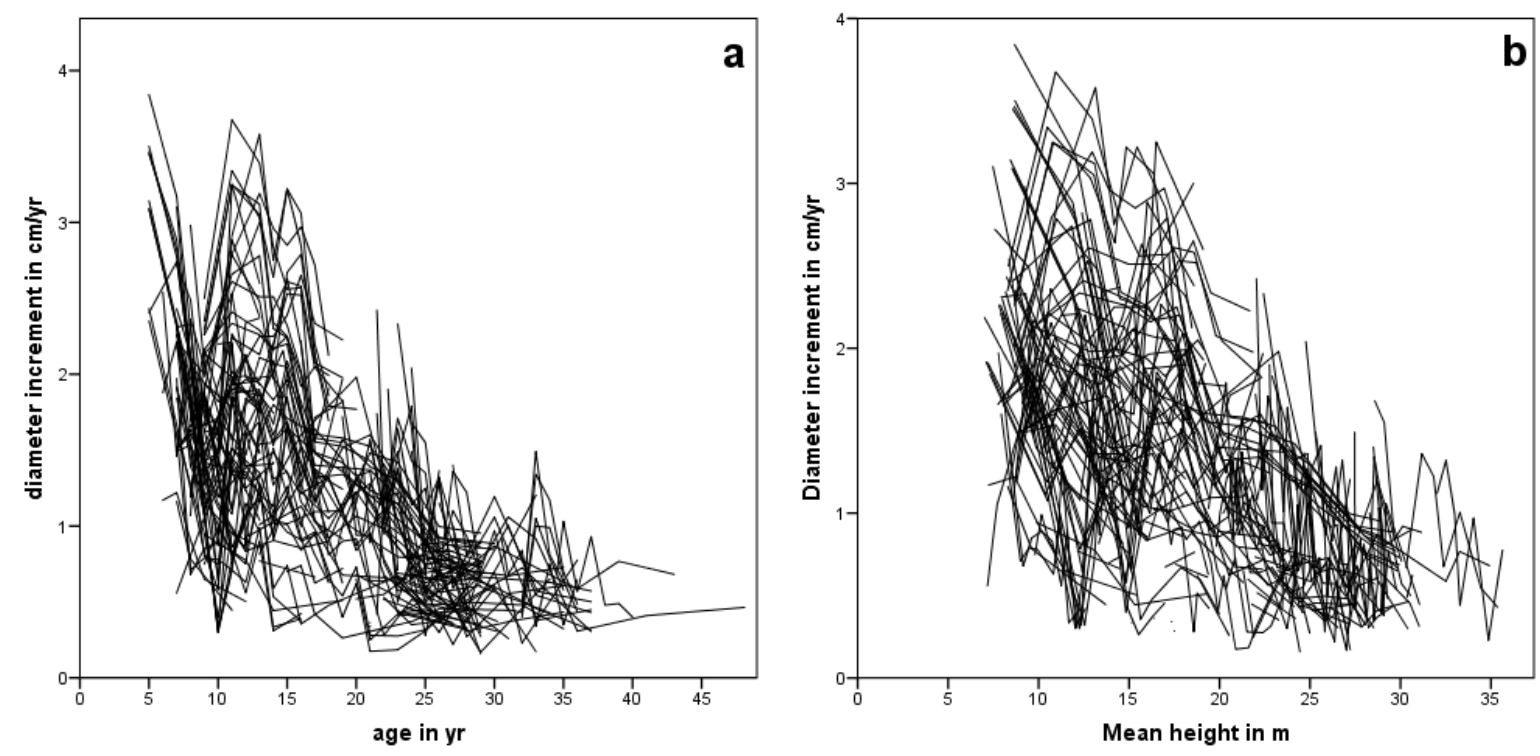

Figuur 20. Diameterbijgroei per proefperk als functie van leeftijd (a) en hoogte (b)

Figure 20. Diameter increment per plot as a function of age (a) and height (b)

Jansen et al. (2016) gebruikten voor de diameterbijgroei van douglas hetzelfde model als bij de grondvlakbijgroei: 


$$
i_{d, i j k}=Y I_{j} \cdot P L_{k} \cdot f_{1}(S \%) \cdot f_{2}(\text { site }) \cdot \frac{F_{3}\left(t_{2}, h_{2}\right)-F_{3}\left(t_{1}, h_{1}\right)}{t_{2}-t_{1}}
$$

Uitgewerkt zonder het plotniveau luidt deze functie voor populier:

$$
\begin{aligned}
& i_{d}=b_{11} \cdot h_{25}^{b_{12}} \cdot \operatorname{cor}_{s \%} \cdot\left\{b_{17} \cdot T_{h}+\left(1-b_{17}\right) \cdot T_{t}\right\} \cdot c f_{80} / d t \quad \text { for } h_{1}>7 \\
& \text { where } c o r_{s \%}= \begin{cases}1 & \text { for } S \% \leq b_{14} \\
1+b_{13} \cdot\left(S \%-b_{14}\right)^{b_{15}} & \text { for } b_{14}<S \% \leq b_{16} \\
1+b_{13} \cdot\left(b_{16}-b_{14}\right)^{b_{15}} & \text { for } S \%>b_{16}\end{cases} \\
& T_{h}=\left(h_{2 c}-1.30\right)^{b_{18}}-\left(h_{1}-1.30\right)^{b_{18}} \text { and } T_{t}=\left(t_{2}-t_{130}\right)^{b_{18}}-\left(t_{1}-t_{130}\right)^{b_{18}} \\
& h_{1} \text { and } h_{2} \text { are the top heights at time } t_{1} \text { and } t_{2} \\
& h_{2 c}= \begin{cases}h_{2} & \text { for } h_{2}>h_{1} \\
h_{1}+\hat{h}_{2}-\hat{h}_{1} & \text { for } h_{2} \leq h_{1}\end{cases} \\
& S \%=\text { Hart Becking spacing index at } t_{1} \text {, see Formula } 1 \\
& c f_{80}=1
\end{aligned}
$$

Met een $R^{2}$ adj van 0.801 werd de oplossing van Tabel 16 gevonden. De correctiefactor $c f_{80}$ (de vervangende factor voor de niet schatbare jaarindex $Y I$ ) met een waarde voor opname voor en na 1980 bleek voor beide groepen significant niet van 1 te verschillen. De parameter $b_{16}$ is een soort bovengrens aan de standruimte, een nog grotere standruimte levert geen extra diameteraanwas op. Deze komt in het oorspronkelijke model van Jansen et al. (2106) niet voor, omdat een dergelijke ruime stand (meestal aangeduid als boomweide) bij de douglas niet voorkomt. De onderscheiden subgroep 'Androscoggin' uit Paragraaf 4.2.1 was niet van belang, wel de andere subgroep 'Geneva'.

Tabel 16. Parameterschatting bij Model (26) en Model (28)

Table 16. Parameter estimation for Model (26) and Model (28)

\begin{tabular}{|l|r|r|r|r|}
\hline & & & \multicolumn{2}{|c|}{ 95\% Confidence Interval } \\
\cline { 4 - 5 } Parameter & Estimate & Std. Error & Lower Bound & Upper Bound \\
\hline$b_{11}$ & 0.0522 & 0.015 & 0.022 & 0.082 \\
$b_{12}$ & 0.6243 & 0.084 & 0.460 & 0.788 \\
$b_{13}$ & 0.1738 & 0.040 & 0.095 & 0.252 \\
$b_{14}$ & 24.7802 & 0.619 & 23.566 & 25.995 \\
$b_{15}$ & 0.6963 & 0.051 & 0.597 & 0.795 \\
$b_{16}$ & 63.6559 & 2.588 & 58.576 & 68.736 \\
$b_{17}$ & 0.5737 & 0.023 & 0.529 & 0.618 \\
$b_{18}$ & 1.1621 & 0.030 & 1.104 & 1.220 \\
\hline$b_{19}$ & 0.9871 & 0.008 & 0.971 & 1.003 \\
\hline$b_{11 \text { Geneva }}$ & 0.0706 & 0.020 & 0.031 & 0.110 \\
\hline
\end{tabular}




\subsubsection{Keuze voor directe of indirecte schatter van grondvlakbijgroei}

In een te maken opbrengstmodel zal de diameterbijgroei van Paragraaf 4.2 .2 als volgt moeten worden getransformeerd tot grondvlakbijgroei:

$$
\begin{aligned}
& \hat{d}_{b t}\left(t_{2}\right)=d_{a t}\left(t_{1}\right)+d t \cdot \hat{i}_{d} \\
& \rightarrow \hat{G}_{b t}\left(t_{2}\right)=N_{b t}\left(t_{2}\right) \cdot\left\{\frac{\hat{d}_{b t}\left(t_{2}\right)}{200}\right\}^{2} \cdot \pi \\
& \rightarrow \hat{I}_{G}=\frac{\hat{G}_{b t}\left(t_{2}\right)-G_{a t}\left(t_{1}\right)}{d t}
\end{aligned}
$$

Schatter (27) is echter niet zuiver en een biascorrectie is nodig met het volgende model:

$$
\hat{\imath}_{G}=b_{19} \cdot \hat{l}_{G}
$$

De $R^{2}$ adj van de laatste stap bedraagt 0.768 met een standaardafwijking van $0.37 \mathrm{~m}^{2} \mathrm{ha}^{-1} \mathrm{jr}^{-1}$. De $R^{2}$ adj van de indirecte schatter $(0.768)$ is dus beduidend lager die van de directe schatter (0.804).

De directe schatter voor de grondvlakbijgroei van Paragraaf 4.2.1 zal daarom in het totale opbrengstmodel worden opgenomen. De ontwikkeling van de diameter zal dan indirect berekend worden via de grondvlakbijgroei (zie Paragraaf 6.2.2).

\subsection{Grondvlakbijgroei voor hoogte boven de $7 \mathrm{~m}$ bij dichte stand}

Bij het bepalen van de grondvlakbijgroei boven 7 meter in dichte stand zijn de experimentele proefperken geselecteerd met een begin-afstand $s p_{0} \leq 3 \mathrm{~m}$, waarin niet gedund is en waar eventueel wel sterfte voorkwam, dat betreffen de proefperken 108 - 111, 119, 122 - 126, $129-132$ uit de studie 3 en 8 . In totaal betreft het 77 opnamen. Beide methoden van Paragraaf 4.2.1 en Paragraaf 4.2.2 zijn getest en de indirecte schatting van de grondvlakbijgroei met behulp van de diameterbijgroei voldeed het best en alleen daarvan volgt verslag.

Bij beide methoden speelt het $S \%$ een rol, in $40 \%$ van de opname is sterfte aan de orde, die zelfs tot $95 \%$ kan oplopen, hierdoor verliest het $S \%$ zijn waarde als maat voor de dichtheid. Om dit op te lossen is gekozen voor een aangepaste definitie:

$$
S_{0} \%=\frac{s p_{0}}{h_{a t}} \cdot 100=\frac{100}{h_{a t}} \cdot \sqrt{\frac{10000}{N_{0}}}
$$

In Figuur 21 is diameterbijgroei per proefperk weergegeven zowel als functie van hoogte als van het aangepaste $S_{0} \%$. De hier niet getekende relatie met de leeftijd vertoont eenzelfde beeld als Figuur 21a. 

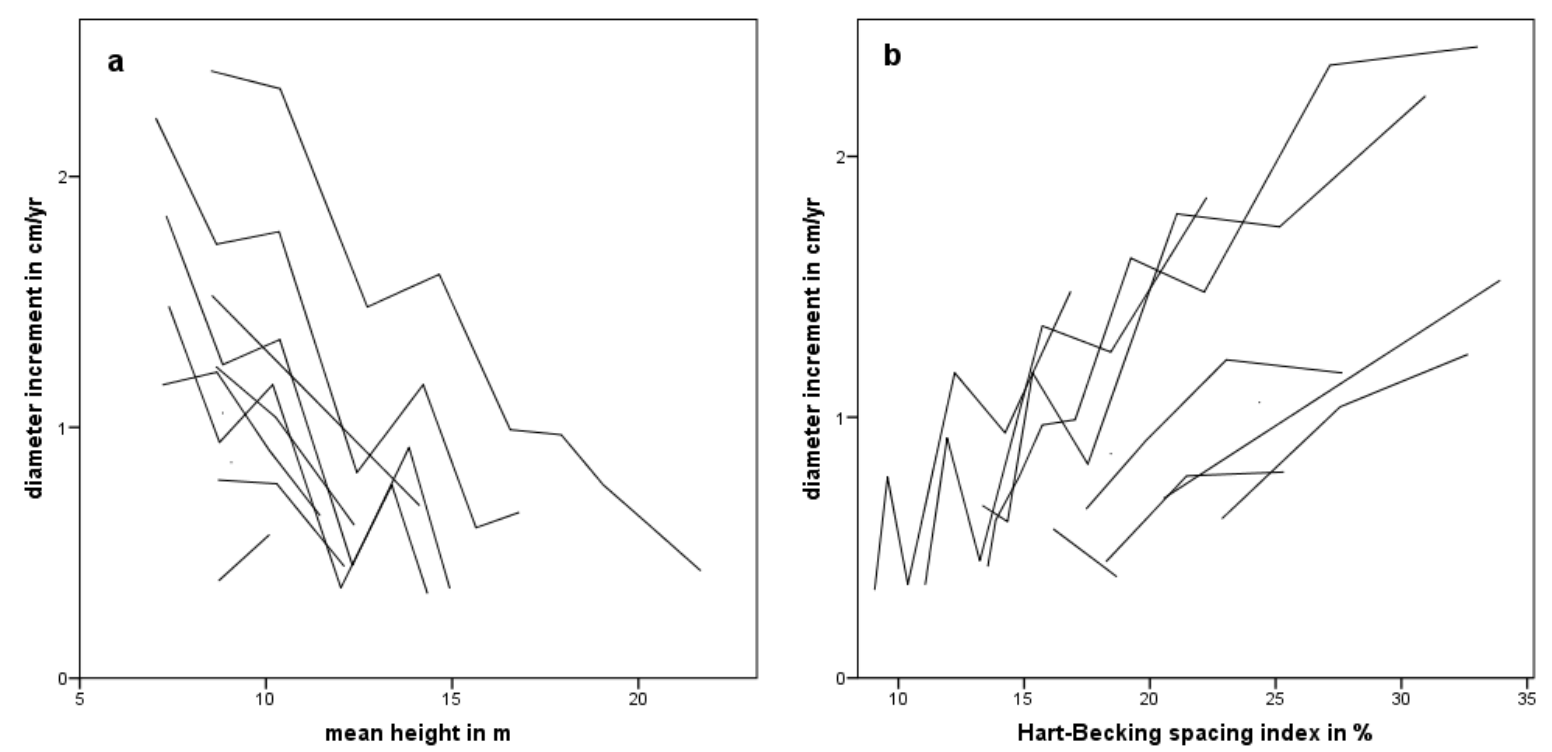

Figuur 21. Diameterbijgroei per proefperk als functie van hoogte (a) en $S_{0} \%$ (b).

Figure 21. Diameter increment as a function of height (a) and S\% (b).

Het eerder gebruikte model (26) is opnieuw geparametriseerd en luidt nu met weglating van de niet-significante onderdelen, een aanpassing van de correctieterm voor het $S_{0} \%$ en een schaling van $h_{25}$ als volgt:

$$
\begin{gathered}
i_{d}=c_{18} \cdot\left(h_{25} / 25\right)^{c_{19}} \cdot \operatorname{cor}_{S_{0} \%} \cdot\left\{c_{22} \cdot T_{h}+\left(1-c_{22}\right) \cdot T_{t}\right\} / d t \quad \text { for } h>7 \mathrm{~m} \\
\text { where } \operatorname{cor}_{s_{0} \%}= \begin{cases}1 & \text { for } S_{0} \%>c_{21} \\
1-c_{20} \cdot\left(c_{21}-S_{0} \%\right) & \text { for } S_{0} \% \leq c_{21}\end{cases} \\
T_{h}=\left(h_{2 c}-1.30\right)^{c_{23}}-\left(h_{1}-1.30\right)^{c_{23}} \text { and } T_{t}=\left(t_{2}-t_{130}\right)^{c_{23}}-\left(t_{1}-t_{130}\right)^{c_{23}} \\
\hat{h}_{2}=h_{1}+d h_{\text {pred }}=h_{1}+\left(h_{2 \text { pred }}-h_{1 \text { pred }}\right)=h_{1}+f_{17}\left(t_{2}\right)-f_{17}\left(t_{1}\right) \\
f_{17} \text { means Formula } 17 \\
S_{0} \%=\text { adjusted Hart Becking spacing index at } t_{1} \text {, see Formula } 30
\end{gathered}
$$

De oplossing had met 77 waarnemingen een $R^{2}$ adj van 0.901 en een standaarddeviatie van $1.8 \mathrm{~mm} / \mathrm{jr}$, zie Tabel 17 (NB de parameter $c_{24}$ komt later aan de orde).

Tabel 17. Parameters bij model (30) en (32).

Table 17. Parameters for model (30) and (32).

\begin{tabular}{|l|r|r|r|r|}
\hline \multirow{2}{*}{ Parameter } & & & \multicolumn{2}{|c|}{ 95\% Confidence Interval } \\
\cline { 4 - 5 } & Estimate & Std. Error & Lower Bound & \multicolumn{1}{c|}{ Upper Bound } \\
\hline$c_{18}$ & 1.9824 & d0.675 & 0.636 & 3.329 \\
$c_{19}$ & 2.6989 & 0.305 & 2.091 & 3.307 \\
$c_{20}$ & 0.0371 & 0.003 & 0.030 & 0.044 \\
$c_{21}$ & 29.2340 & 1.575 & 26.094 & 32.374 \\
$c_{22}$ & 0.3617 & 0.115 & 0.132 & 0.591 \\
$c_{23}$ & 0.7464 & 0.100 & 0.547 & 0.946 \\
\hline$c_{24}$ & 1.0176 & 0.030 & 0.957 & 1.078 \\
\hline
\end{tabular}


Voor het maken van een opbrengstmodel zal die diameterbijgroei als volgt moeten worden getransformeerd tot grondvlakbijgroei:

$$
\begin{aligned}
& \hat{d}_{b t}\left(t_{2}\right)=d_{a t}\left(t_{1}\right)+d t \cdot \hat{i}_{d} \\
& \rightarrow \hat{G}_{b t}\left(t_{2}\right)=N_{b t}\left(t_{2}\right) \cdot\left\{\frac{\hat{d}_{b t}\left(t_{2}\right)}{400}\right\}^{2} \cdot \pi \\
& \rightarrow \hat{I}_{G}=\frac{\hat{G}_{b t}\left(t_{2}\right)-G_{a t}\left(t_{1}\right)}{d t}
\end{aligned}
$$

Schatter (31) is echter niet zuiver en een biascorrectie is nodig met het volgende model:

$$
\hat{\imath}_{G}=c_{24} \cdot \hat{l}_{G}
$$

$R^{2}$ adj van deze laatste stap bedraagt 0.797 met een standaardafwijking van $0.99 \mathrm{~m}^{2} \mathrm{ha}^{-1} \mathrm{jr}^{-1}$.

\section{Kwaliteit van het model}

In Figuur 22a zijn de gestandaardiseerde residuen van model (30) uitgezet tegen de modelvariabele hoogte. Een vergelijkbaar beeld (hier niet getekend) ontstaat als de gestandaardiseerde residuen van model (30) tegen de leeftijd $h_{40}$ of $s p_{0}$ worden uitgezet. In Figuur 22b zijn de gestandaardiseerde residuen van model (32) uitgezet tegen de hoogte. Er zijn twee uitbijters waar geen verklaring voor is gevonden. De lichte hellingshoeken van beide lijnen met de beste lineaire fit zijn niet significant.
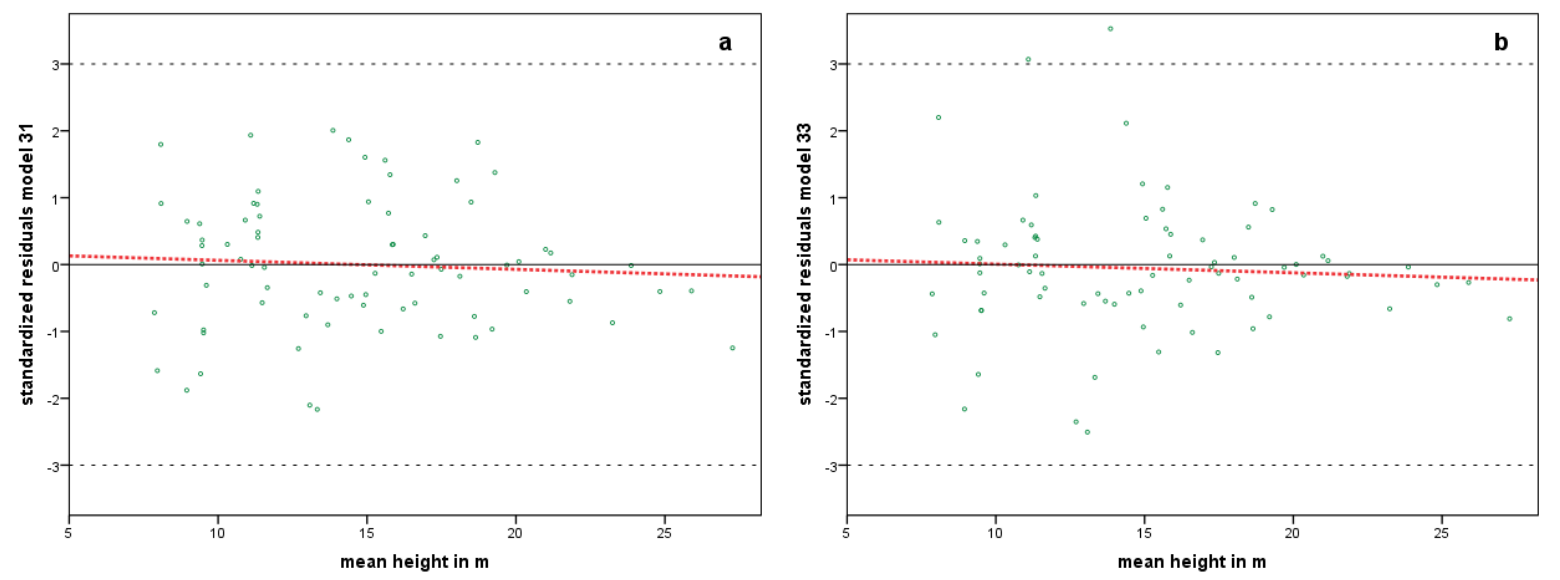

Figuur 22. Gestandaardiseerde residuen van model (30) in relatie tot hoogte (a) en de gestandaardiseerde residuen van model (32) in relatie tot hoogte (b). De rode lijn is de lineaire regressielijn door de residuen.

Figure 22. Standardized residuals of model (30) in relation to height (a) and standardized residuals of model (32) in relation to height (b), the red lines represent the linear fit. 


\subsection{Grondvlakbijgroei in lijnbeplantingen}

In Paragraaf 4.2.1 is besloten om de analyse van grondvlakbijgroei van de lijnbeplantingen te splitsen van die in bossen.

Er zijn 32 proefperken met 282 opnamen beschikbaar voor de analyse van de opstandontwikkeling bij lijnbeplantingen. Er is met vier methoden geanalyseerd:

1. Directe schatting van de grondvlakbijgroei met de methode van Paragraaf 4.2.1 met $R^{2}$ adj $=0.428$;

2. Indirecte schatting van de grondvlakbijgroei met de methode van Paragraaf 4.2.2 met $R^{2} \mathrm{adj}=0.468$;

3. Directe schatting van het grondvlak met $G_{\text {tot }}$ met $R^{2}$ adj $=0.879$.

4. Indirecte schatting van het grondvlak $G_{b t}$ met de diameterontwikkeling met $R^{2}$ adj $=0.944$.
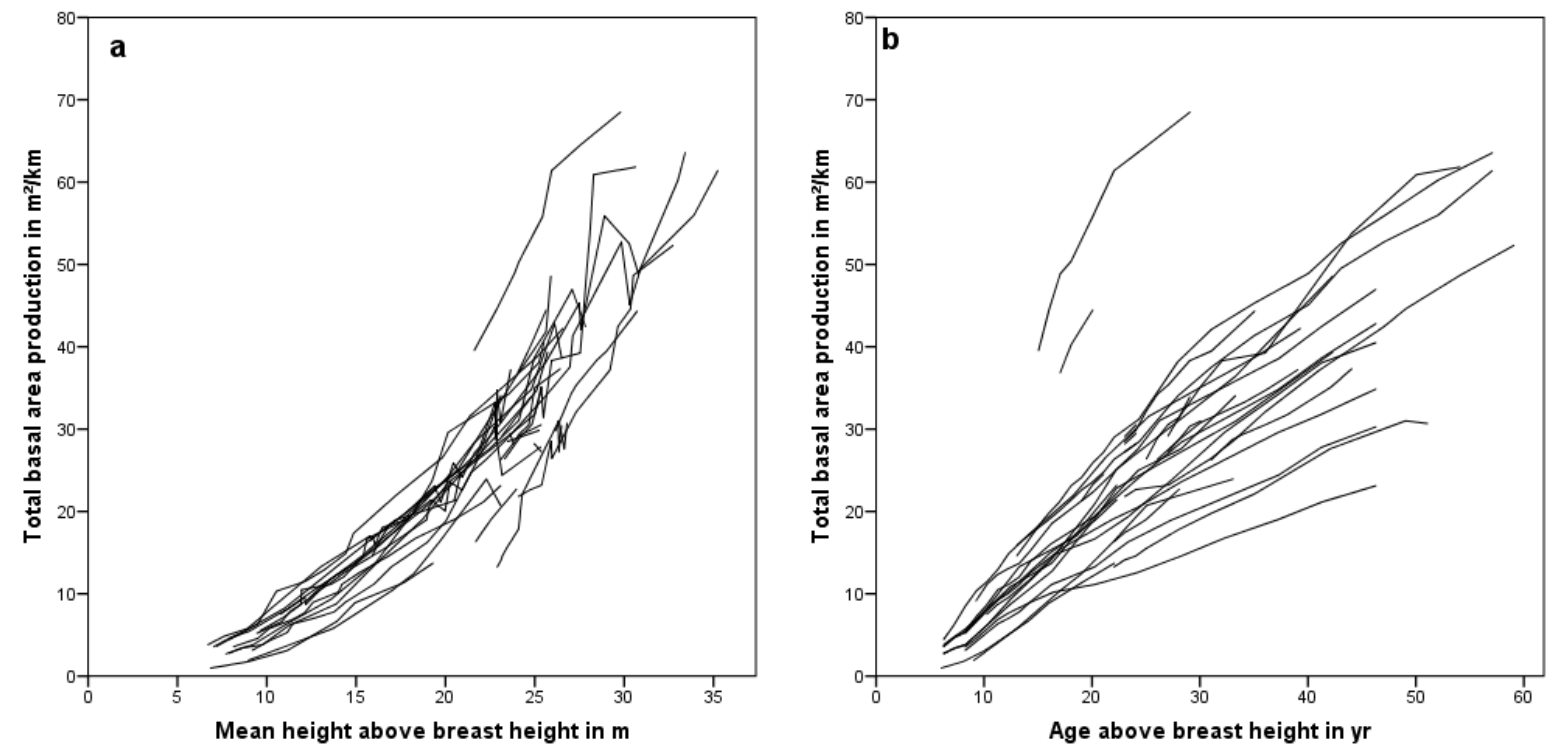

Figuur 23. Totale grondvlakproductie per proefperk $\left(G_{t o t}\right)$ als functie van hoogte $(a)$ en leeftijd (b).

Figure 23. The total basal area per plot $\left(G_{\text {tot }}\right)$ as a function of height (a) and age (b).

De vierde methode is gekozen, zowel de $3^{\mathrm{e}}$ als de $4^{\mathrm{e}}$ methode worden nu besproken.

Directe schatting van de totale grondvlakproductie

In Figuur 23 is de ontwikkeling van de totale grondvlakproductie weergegeven als functie van de hoogte (a) en de leeftijd (b). Jansen et al. (2016) geven in Paragraaf 4.2.1 een oplossing om de grondvlakbijgroei te schatten via de ontwikkeling van het totale grondvlak (de som van het huidig grondvlak na dunning en het gecumuleerde gedunde grondvlak tot dat moment). Maar aangezien dat in de meeste gevallen onbekend is, zien ze er verder vanaf. Als functie vonden zij een powerfunctie naar de hoogte die voor een referentieleeftijd van 25 jaar is herschreven als: 


$$
\begin{aligned}
G_{\text {tot }} & =G_{25} \cdot f_{a}(h) \\
& \text { where } G_{25}=f_{b}(S \%, h)
\end{aligned}
$$

Voor de lijnbeplantingen van populier bleek met een $R^{2}$ adj van voor $f_{a}$ een Chapman-Richards-functie naar leeftijd een betere keus:

$$
G_{\text {tot }}=G_{25 j} \cdot\left\{\frac{1-\exp \left(-b_{25} \cdot\left(t-t_{1.30}\right)\right)}{1-\exp \left(-b_{25} \cdot\left(25-t_{1.30}\right)\right)}\right\}^{b_{26}} \text { for the } j^{\text {th }} \text { plot }
$$

In Formule (34) zijn naast de 2 modelparameters de plotparameters $\left(G_{25}\right)$ geschat die het productieniveau representeren. Met een variantieanalyse en een $R^{2}$ adj van 0.923 is vervolgens gezocht naar verklarende variabelen voor dit productieniveau. Dit bleken de variëteit, de plantafstand, de boniteit en de regio. De regio en variëteit zijn weggelaten en het model luidt dan:

$$
\begin{gathered}
G_{\text {tot }}=G_{25} \cdot\left\{\frac{1-\exp \left(-b_{25} \cdot\left(t-t_{1.30}\right)\right)}{1-\exp \left(-b_{25} \cdot\left(25-t_{1.30}\right)\right)}\right\}^{b_{26}} \\
\text { where } G_{25}=b_{27} \cdot s p_{0}+b_{28} \cdot h_{25}^{b_{29}}
\end{gathered}
$$

Aangezien de grondvlakbijgroei en daardoor ook $G_{\text {tot }}$ wordt beïnvloed door dunningen kunnen alleen data worden gebruikt tot en met de eerste dunning. Dat betreft 28 proefperken met 157 opnamen met een goede spreiding over de leeftijden en boniteiten. Naast dunningen verdwijnen er wegens andere reden af en toe bomen, hier is niet voor gecorrigeerd.

Met een $R^{2}$ adj van 0.879 en een standaarddeviatie van $4.6 \mathrm{~m}^{2} \mathrm{ha} \mathrm{A}^{-1}$ volgt een oplossing. Hierna is het productieniveau per variëteit $(V L)$ berekend:

$$
\begin{aligned}
G_{\text {tot }}= & \hat{G}_{\text {tot }}\left(f_{35}\right) \cdot \sum_{j=1}^{5} V L_{j} \cdot x_{j} \\
& \text { where } x_{j}= \begin{cases}1 & \text { if the } j^{\text {th }} \text { variety is in the plot } \\
0 & \text { else }\end{cases}
\end{aligned}
$$

Het $R^{2}$ adj stijgt naar 0.956 en een standaarddeviatie daalt naar $2.8 \mathrm{~m}^{2} \mathrm{ha}{ }^{-1}$. Het productieniveau van 'Robusta' en 'Forrndorf' is gelijk en bedraagt 94\%, voor is het 'Gelrica' $130 \%$, voor 'Heidemij' $83 \%$ en voor 'Serotina' is het $110 \%$.

Formule (35) blijkt dus geschikt om het totale grondvlak per variëteit te verklaren en minder geschikt om voor alle variëteiten samen te gebruiken. 

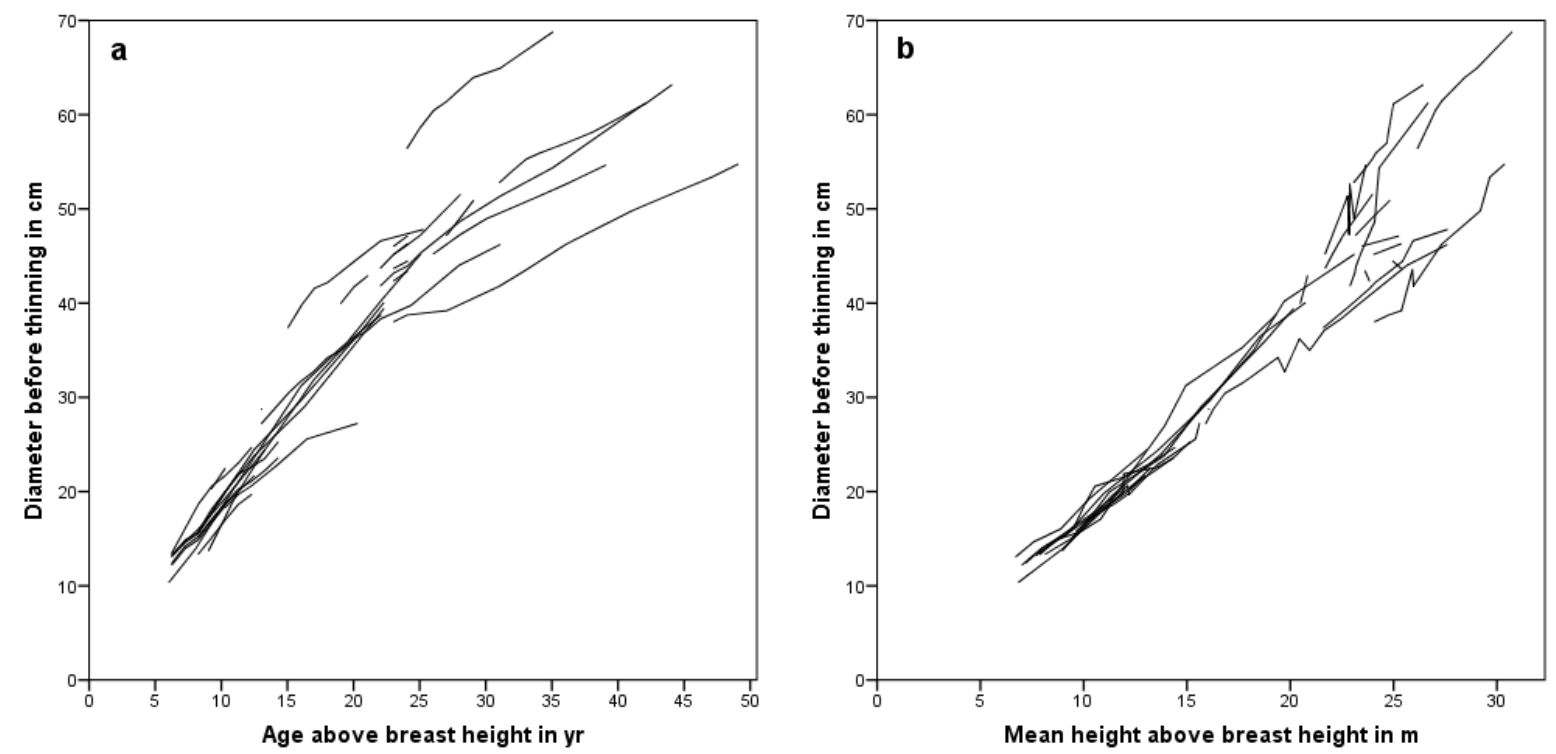

Figuur 24. Diameter na dunning per proefperk als functie van leeftijd (a) en hoogte (b).

Figure 24. Diameter after thinning per plot as a function of age (a) and height (b).

In Figuur 24 is de ontwikkeling van de diameter voor dunning gegeven als functie van de leeftijd (a) en de hoogte (b). Anders dan bij Figuur 23 zijn nu net als hiervoor alleen de opnamen gebruikt tot en met de eerste dunning.

Jansen (1990) geeft een voorlopige opbrengsttabel voor lijnbeplantingen van populier, hij gebruikt hiervoor dezelfde data als in onze studie. Maar op dat moment was slechts $40 \%$ van de data ontsloten. Jansen (1990) en De Vries (1962) rapporteerden een verschil tussen de diameter in de rij $\left(d_{i r}\right)$ en die daar loodrecht op $\left(d_{\text {or }}\right)$. Jansen (1990) geeft een aantal mogelijke verklaringen, die alle te maken hebben met het kroonoppervlak. Maar geen van de mogelijke verklarende factoren is gemeten en daardoor niet bruikbaar. Jansen (1990) modelleert de ontwikkeling van $d_{\text {or }}$ met een Schnute-variant (1981) van een Chapman-Richardsfunctie als volgt:

$$
d_{\text {or }}=D_{30} \cdot\left\{\frac{1-\exp \left(-a_{1} \cdot\left(t-t_{1.30}\right)\right)}{1-\exp \left(-a_{1} \cdot\left(30-t_{1.30}\right)\right)}\right\}^{a_{2}}
$$

where $D_{30}=a_{3}+a_{4} \cdot h_{30}$

Op basis van de Figuren $24 a$ en $24 b$ is de leeftijd als verklarende variabele een goede keus, maar een eventueel ander groeimodel is een optie.

Het Chapman-Richards model bleek de beste keus en functie (37) is in onze studie opnieuw geformuleerd voor de $d_{b t}$ :

$$
\begin{aligned}
& d_{b t}= D_{25} \cdot\left\{\frac{1-\exp \left(-c_{25} \cdot\left(t-t_{1.30}\right)\right)}{1-\exp \left(-c_{25} \cdot\left(25-t_{1.30}\right)\right)}\right\}^{c_{26}} \\
& \text { where } D_{25}=c_{27} \cdot s p_{0}+c_{28} \cdot h_{25}^{c_{29}}
\end{aligned}
$$


Maar aangezien een schatting van de grondvlakontwikkeling nodig is, is Formule (38) uitgebreid tot:

$$
\begin{gathered}
G_{b t}=N_{b t} \cdot \pi \cdot\left(\frac{d_{b t}}{200}\right)^{2} \\
\text { where } d_{b t}=D_{25} \cdot\left\{\frac{1-\exp \left(-c_{25} \cdot\left(t-t_{1.30}\right)\right)}{1-\exp \left(-c_{25} \cdot\left(25-t_{1.30}\right)\right)}\right\}^{c_{26}} \\
D_{25}=c_{27} \cdot s p_{0}+c_{28} \cdot h_{25}^{c_{29}}
\end{gathered}
$$

Met een $R^{2}$ adj van 0.944 en een standaarddeviatie van $3.1 \mathrm{~m}^{2} \mathrm{ha}^{-1}$ geeft Tabel 18 geeft de oplossing.

Tabel 18. Parameters bij Model (39)

Table 18. Parameters for Model (39)

\begin{tabular}{|l|r|r|r|r|}
\hline & & & \multicolumn{2}{|c|}{ 95\% Confidence Interval } \\
\cline { 4 - 5 } Parameter & Estimate & Std. Error & Lower Bound & \multicolumn{1}{c|}{ Upper Bound } \\
\hline$c_{25}$ & 0.0449 & 0.009 & 0.028 & 0.062 \\
$c_{26}$ & 0.9192 & 0.111 & 0.699 & 1.139 \\
$C_{27}$ & 2.1834 & 0.151 & 1.886 & 2.481 \\
$c_{28}$ & 0.2148 & 0.079 & 0.058 & 0.372 \\
$C_{29}$ & 1.5631 & 0.109 & 1.348 & 1.778 \\
\hline
\end{tabular}

\section{Kwaliteit van het model}

In Figuur 25 is te zien dat het model voor de modelvariabele S\% (b) en de nietmodelvariabele hoogte (a) een nagenoeg zuivere schatter geeft, want de lichte hellinghoeken van de lineaire fit door de puntenwolk in de figuren blijken nergens significant. Dat geldt ook voor de (hier niet getoonde) leeftijd.

In Figuur 25b is te zien dat er ook bij zeer lage waarden van het $S \%$ geen bijzondere afwijkingen zijn. Normaliter zou in bossen een dergelijk laag $S \%$ (ca. 10) niet bereikt kunnen worden omdat er dan sterfte optreedt, maar in lijnbeplantingen kan dat wel. Deze lage waarden van het $S \%$ liggen alle in het proefperk P032 Zelhem 1, waar de volumebijgroei fluctueert tussen de 18 en $62 \mathrm{~m}^{3} \mathrm{~km}^{-1} \mathrm{jr}^{-1}$. 

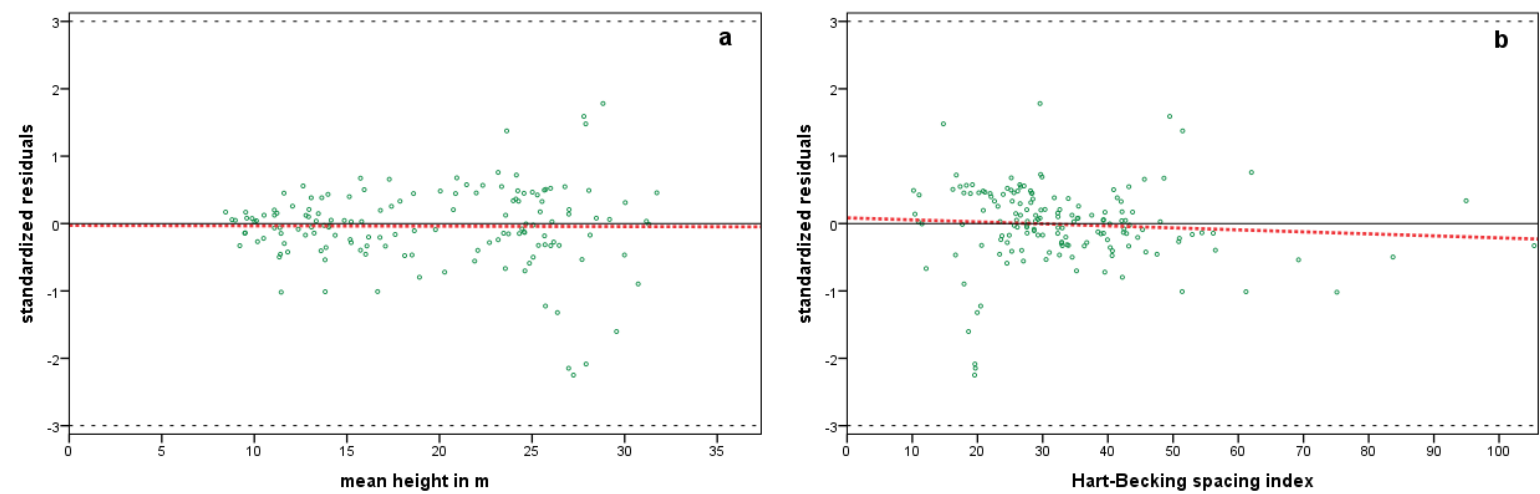

Figuur 25. Gestandaardiseerde residuen van model (39) in relatie tot de modelvariabelen hoogte (a) en S\% (b). De rode lijn geeft de lineaire regressielijn weer door de residuen.

Figure 25. Standardized residuals of model (39) in relation to height (a) and S\% (b). The red lines represent the linear fit.

Net als bij de vorige methode is nagegaan of er verschil is in het productieniveau per variëteit $(V L)$ :

$$
\begin{aligned}
& G_{b t}= \hat{G}_{b t}\left(f_{39}\right) \cdot \sum_{j=1}^{5} V L_{j} \cdot x_{j} \\
& \text { where } x_{j}= \begin{cases}1 & \text { if the } j^{t h} \text { variety is in the plot } \\
0 & \text { else }\end{cases}
\end{aligned}
$$

Het $R^{2}$ adj stijgt naar 0.978 en een standaarddeviatie daalt naar $1.9 \mathrm{~m}^{2} \mathrm{ha} \mathrm{a}^{-1}$. Het productieniveau van 'Robusta' bedraagt $92 \%$, voor 'Forndorf' is het $88 \%$ en voor 'Heidemij' en 'Gelrica' is het $105 \%$, voor en voor 'Serotina' is het $115 \%$.

In Paragraaf 6.6 wordt verder ingegaan op de schatting van $d_{\text {or }}$ en $d_{i r}$.

\section{Conclusie}

De methode gebaseerd op de diameterontwikkeling geeft aanvaardbare uitkomsten zelfs zonder uitsplitsing per variëteit.

\subsection{Conclusie}

De grondvlakbijgroei blijkt in Paragraaf 4.2 goed te voorspellen ( $R^{2}$ adj 0.804 ) voor de bij populier gebruikelijke ruime plantverbanden. Het model en de parameters bleken ook te voldoen voor trilpopulier met laagdunning. In Paragraaf 4.3 is voor de dichte plantverbanden een indirecte schatter van de grondvlakbijgroei gevonden van vergelijkbare relatieve kwaliteit ( $R^{2}$ adj 0.797).

In absolute zin is deze onnauwkeuriger (standaarddeviatie 0.99 tegenover $0.37 \mathrm{~m}^{2} \mathrm{ha}^{-1} \mathrm{jr}^{-1}$ ). Voor lijnbeplantingen zonder dunning en moest in Paragraaf 4.4 een afzonderlijk model worden ontwikkeld. 


\section{Dunningsysteem}

Bij populieren worden veelal in een ruim plantverband aangelegd, bij gebruik van een korte omloop wordt er nooit gedund tot aan de eindkap. Met een wat langere omloop of een iets minder ruime stand vinden er systematische dunningen plaats. In de data komen beide beheersystemen het meest voor (zie Tabel 19). Bij 2 proefperken met een cultivar en 6 met trilpopulier was sprake van een laagdunning. Daarnaast is er sprake van nietsdoen en de daarbij behorende sterfte in de Nelderproeven.

Tabel 19. Proefperken en opnamen per beheersystemen.

Table 19. Number of plots and recordings per management system.

\begin{tabular}{|l|rr|}
\hline beheersysteem & aantal proefperken & aantal opnamen \\
\hline zonder dunning en ruime stand & 77 & 493 \\
systematische dunning & 81 & 834 \\
laagdunning & 8 & 35 \\
geen dunning en sterfte & 27 & 301 \\
\hline Totaal & 193 & 1663 \\
\hline
\end{tabular}

\subsection{Systematische dunning.}

De vraag is hoe deze systematische dunning is uitgevoerd in de dataset en hoe die in bestaande opbrengsttabellen is gemodelleerd.

Er zijn 109 dunningen uitgevoerd, waarbij in 84 gevallen $50 \%$ van het stamtal werd gedund, in 11 gevallen werd 33\% gedund en in 14 gevallen $25 \%$. Daarnaast vond er in 27 gevallen kap van nog geringer omvang plaats. Het gemiddelde grondvlak voor dunning bedroeg in bos $15.8 \mathrm{~m}^{2} \mathrm{ha}^{-1}$, met een standaarddeviatie van $6.0 \mathrm{~m}^{2} \mathrm{ha}^{-1}$. In de lijnbeplantingen was het gemiddelde grondvlak $20.0 \mathrm{~m}^{2} \mathrm{ha}^{-1}$, met een standaarddeviatie van $11.7 \mathrm{~m}^{2} \mathrm{ha} \mathrm{a}^{-1}$. Het gemiddeld S\% bedroeg $42.7 \%$ met een standaarddeviatie van $9.9 \%$. In de lijnbeplantingen was het gemiddelde $S \% 52.0 \%$, met een standaarddeviatie van $16.0 \%$. Het gemiddeld grondvlak bij eindkap bedroeg $26.6 \mathrm{~m}^{2} \mathrm{ha}^{-1}$.

$E r$ is daarom geen éénduidige dunningstrategie te duiden in de data.

In tabel 20 zijn enige karakteristieken gegeven van de eerste stamtal-afname ten gevolge dunning of sterfte. De sterfte in de Nelder-plots vindt alleen plaats in de cirkels met plantafstand kleiner dan $3 \mathrm{~m}$.

Tabel 20. Karakteristieken van eerste stamtalreductie door dunning of sterfte.

Table 20. Characteristics of first reduction of number of trees by thinning or mortality.

\begin{tabular}{|l|r|r|r|r|}
\hline beheersysteem & $\boldsymbol{n}$ & $\begin{array}{r}\boldsymbol{S \%} \text { voor } \mathbf{1}^{\text {st }} \\
\text { afname van } \mathbf{N} / \text { ha }\end{array}$ & $\begin{array}{r}\boldsymbol{S} \% \text { na } \mathbf{1}^{\text {st }} \\
\text { afname van } \mathbf{N} / \mathbf{h a}\end{array}$ & $\begin{array}{r}\text { afname \% } \\
\text { van } \boldsymbol{N} \_b t\end{array}$ \\
\hline systematische dunning & 44 & 23.7 & 35.1 & 42.2 \\
geen dunning en sterfte & 11 & 11.7 & 17.2 & 35.8 \\
\hline
\end{tabular}

Er is besloten een plantafstand van $5 \times 5 \mathrm{~m}$ te gebruiken en een dunning uit te voeren van $50 \%$ zodra het $S \%$ onder de grens van $20.5 \%$ daalt. In de variant waarin er niet gedund volgt 
eindkap zodra het $S \%$ onder de grens van $17.5 \%$ daalt. Daarnaast zijn er tabellen berekend bij de plantafstanden 4, 6, 7, 8, 9 en 10 m, deze zijn niet alle opgenomen in Bijlage 1, maar wel gebruikt in Paragraaf 6.5. Er is ook een tabel opgenomen in Bijlage 1 met een zeer wijd plantverband van $10.2 \times 10.2$ m en een "free growth" dunning, er wordt hier gedund zodra het $S \%$ onder de grens van de waarde van $b_{16}$ uit Formule (26) daalt. In het overall opbrengsttabelmodel is deze grenswaarde verder aangeduid als $c_{30}(\approx 64 \%)$. Dit beheersysteem wordt toegepast bij het agroforestry-beheer "Boomweide".

Daarnaast is er een model gemaakt waarbij in een zeer korte omloop een plantverband van $2 \times 2$ is gebruikt, met eindkap zodra het $S \%$ onder de grens van $14.5 \%$ daalt, onder die grens treedt er namelijk sterfte op. Daarnaast zijn er tabellen berekend bij de plantafstanden 1, 1.5 en $2 \mathrm{~m}$. Dit beheersysteem wordt aangeduid als Biomassa-beplantingen.
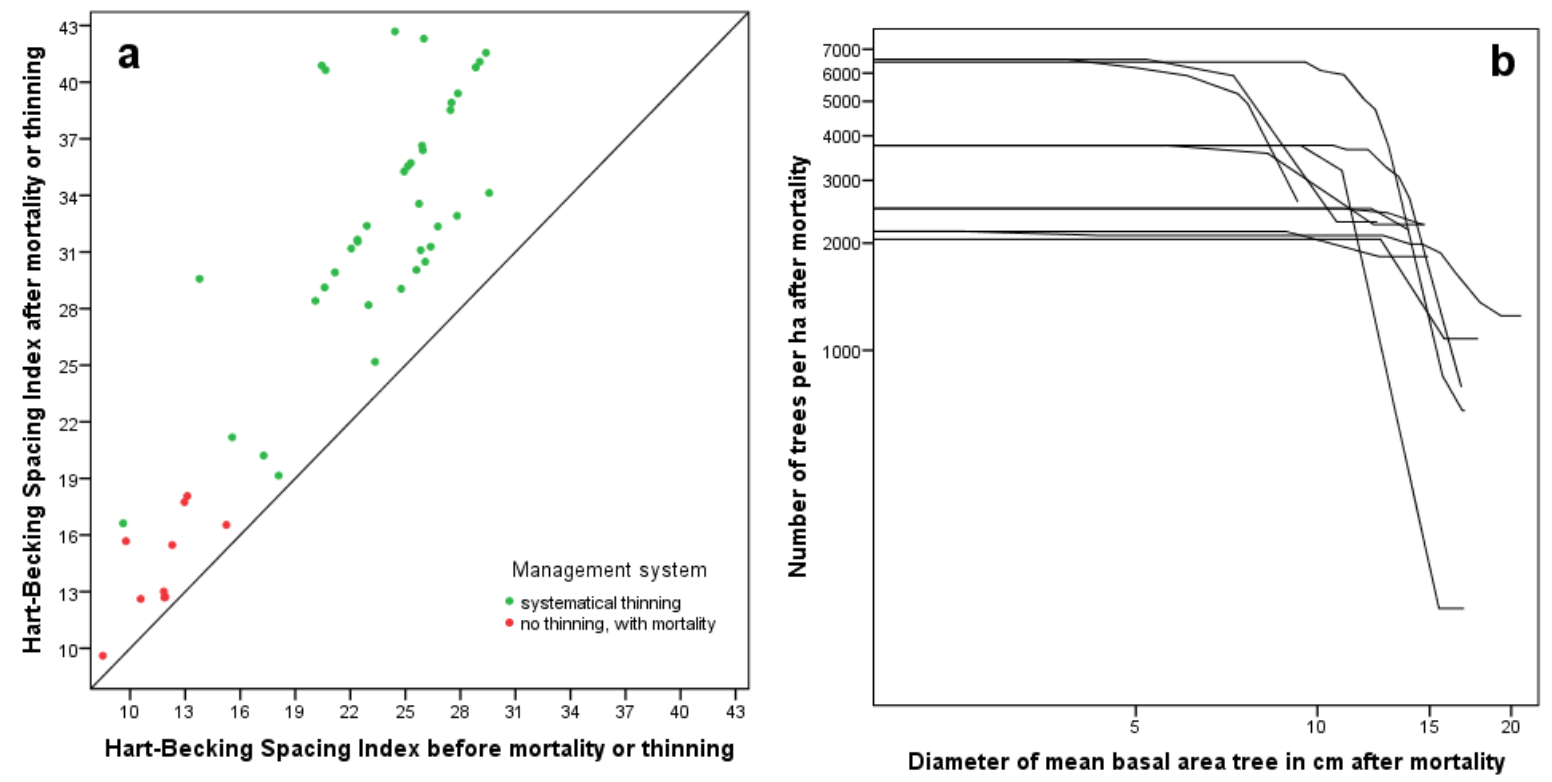

Figuur 26. Relatie S\% voor en na eerste stamtalreductie door dunning of sterfte (a) en logaritmische Reineke-relatie tussen stamtal en diameter na dunning voor de plots met sterfte (b).

Figure 26. Relationship between S\% before and after reduction of number of trees by thinning or mortality (a) and logarithmic Reineke-relationship between stem density and diameter after mortality (b).

In Figuur 26a is de verschuiving in S\% aangegeven ten gevolge van dunning of sterfte er is nauwelijks sprake van enig verband. De logaritmische relatie tussen het stamtal en de diameter na (zelf)dunning blijkt voor de klonen op geen enkele manier te voldoen aan het Reineke-model (Reineke, 1933). De hellingshoek heeft een tangens van ongeveer -2.1, dus veel steiler dan de -1.6 van Reineke (zie Figuur 26b).

\subsection{Laagdunning bij trilpopulier}

La Bastide en Faber (1972) voorspellen de diameter na dunning met:

$$
d_{a t}=d_{b t} \cdot\left\{R \cdot \frac{a_{a t}}{a_{b t}}+1-R\right\} \text { where } a_{a t}, a_{b t} \text { are mean tree distances before and after thinning }
$$


Jansen et al. (2016) gebruiken een modificatie ervan met $R=f\left(h_{25}, S \%, t\right)$. Er zijn 8 proefperken met trilpopulier waarvan 6 met laagdunning met maar 16 opnamen, waarbij gedund werd. Dat is veel te weinig om modificatie toe te passen. Besloten is daarom het originele model van La Bastide en Faber te draaien met $R=c_{31}$.

Met een $R^{2}$ adj van 0.984 werd de oplossing van Tabel 21 gevonden. Het gemiddelde $S \%$ in de opnamen bedroeg $23 \%$, waarmee er sprake is van een zware laagdunning.

Tabel 21. Parameterschatting met het model van La Bastide \& Faber.

Table 21. Parameter estimation with La Bastide \& Faber's model

\begin{tabular}{|l|r|r|r|r|}
\hline & & & \multicolumn{2}{|c|}{ 95\% Confidence Interval } \\
\cline { 4 - 5 } Parameter & Estimate & Std. Error & Lower Bound & Upper Bound \\
\hline$C_{31}$ & 0.3287 & 0.025 & 0.275 & 0.382 \\
\hline
\end{tabular}

\subsection{Sterfte bij dichte stand}

In Paragraaf 4.3 is de grondvlakbijgroei besproken van 14 proefperken met dichte stand met in totaal 77 opname. In 33 daarvan trad door de groei sterfte op ten gevolge van die dichte stand. In Figuur 27 is het cumulatieve sterftepercentage weergegeven ten opzichte van het $S$ $\%$. Het $S \%$ is hier steeds berekend ten opzichte van het beginstamtal en zal daarom verder als $S_{0} \%$ worden aangeduid.
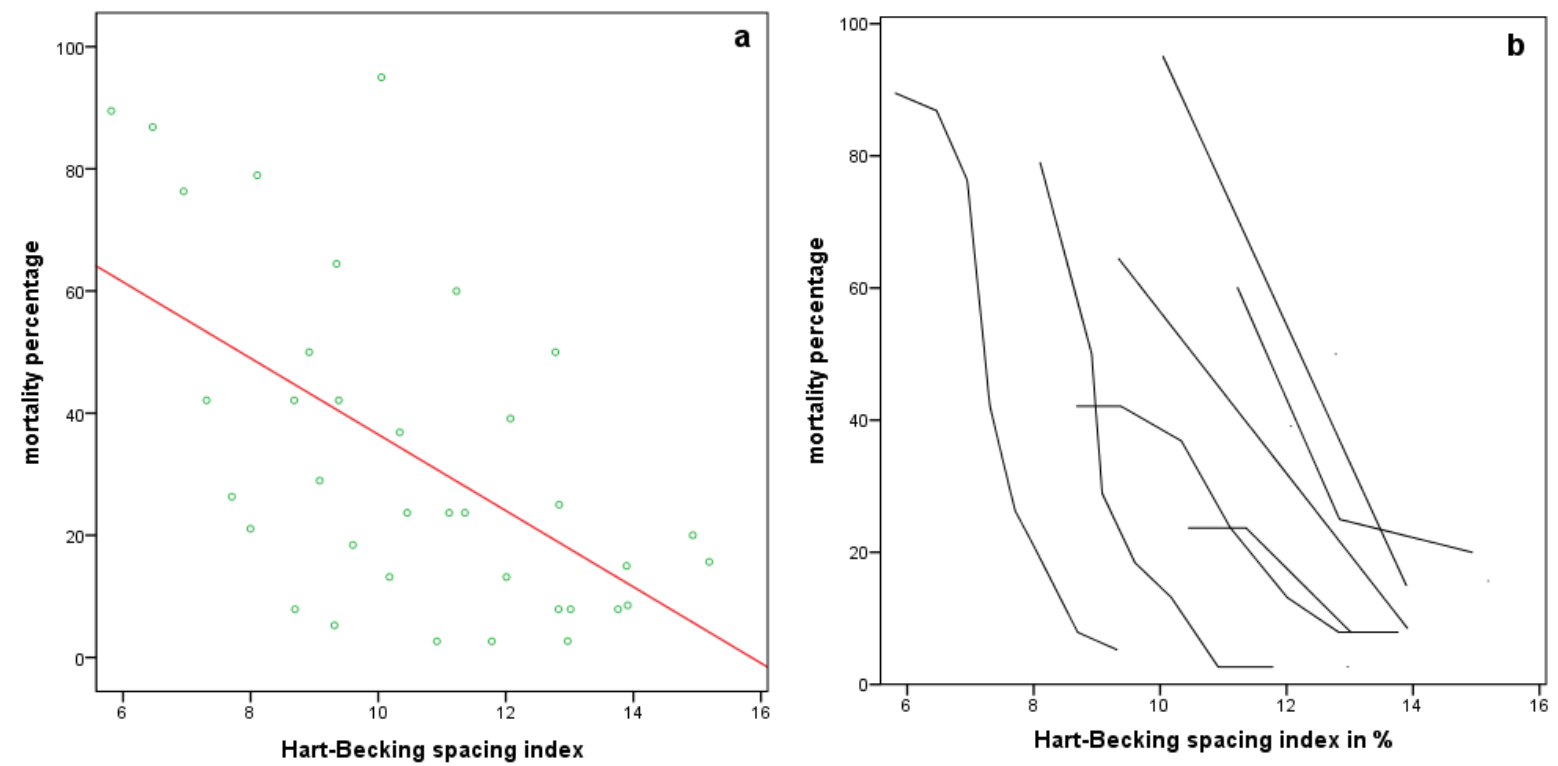

Figuur 27. Diameterbijgroei als functie van $S \%$ met de afzonderlijke waarnemingen en in rood de lineaire fit (a) en zelfde data maar dan met de ontwikkeling per proefperk (b).

Figure 27. Diameter increment per as a function of $S \%$ with the individual observations and in red the linear fit (a) and same data but with the development per plot (b).

Bij het vinden van relatie tussen het sterftepercentage en $S_{0} \%$ blijkt de werkwijze van Figuur 27 a een verkeerd beeld te geven. Want bekijken we het proces per proefperk, zoals in Figuur 
27b dan blijkt de sterfte veel sneller te gaan, dit is als volgt gemodelleerd met één intercept per proefperk en een constante hellinghoek voor alle proefperken:

$$
\begin{aligned}
\text { Mort } \%= & a_{i}-c_{35} \cdot S_{0} \% \\
& \text { where } a_{i} \text { have different values for every } i^{\text {th }} \text { plot }
\end{aligned}
$$

De $R^{2}$ adj bleek 0.668. Vervolgens is geprobeerd $a_{i}$ te verklaren met de kenmerken beginstamafstand, $h_{25}$ en variëteit. De variëteit bleek niet significant, wat tot het volgende model leidde:

$$
\begin{aligned}
\text { Mort } \%= & \begin{cases}0 & \text { for } u \leq 0 \\
u & \text { for } u>0\end{cases} \\
& \text { where } u=c_{32}+c_{33} \cdot s p_{0}+c_{34} \cdot h_{25}-c_{35} \cdot s_{0} \%
\end{aligned}
$$

Met een $R^{2}$ adj van 0.690 en 37 opnamen zijn de constanten van Tabel 22 gevonden.

Tabel 22. Parameterschatting met Model (43).

Table 22. Parameter estimation with Model (43).

\begin{tabular}{|l|r|r|r|r|}
\hline & & & \multicolumn{2}{|c|}{ 95\% Confidence Interval } \\
\cline { 4 - 5 } Parameter & Estimate & Std. Error & Lower Bound & Upper Bound \\
\hline$c_{32}$ & 405.9037 & 48.693 & 306.838 & 504.970 \\
$c_{33}$ & 18.7183 & 6.432 & 5.631 & 31.805 \\
$c_{34}$ & -8.6137 & 1.338 & -11.337 & -5.891 \\
$c_{35}$ & 13.4782 & 1.599 & 10.226 & 16.731 \\
\hline
\end{tabular}

Er resteert de vraag of de diameter van de gestorven bomen afwijkt van die van de blijvers, in bossen met natuurlijke sterfte en voldoende genetische variatie is dat wel het geval. Of dat bij klonen een rol speelt is niet bekend. Met een variatie op model (41) is dit onderzocht, na weglating van de niet significante onderdelen luidt dit:

$$
d_{a m}=d_{b m} \cdot\left\{c_{36} \cdot \frac{a_{a m}}{a_{b m}}+1-c_{36}\right\} \text { where } a m \text { and } b m \text { means after and before mortality }
$$

Met een $R^{2}$ adj van 0.989 en 37 opnamen werd de volgende constante gevonden $c_{36}=0.1094$ in het betrouwbaarheidsinterval $\{0.089 ; 0.130\}$. 


\section{Constructie Opbrengsttabellen}

Met de in deze studie gevonden relaties zullen nu nieuwe opbrengsttabellen worden gemaakt met verschillende dunninggraden.

Al eerder is besloten een indeling in relatieve boniteiten te maken, met daaraan gekoppeld de "hoogte" op 25 jaar. Er is gekozen voor een presentatie van gegevens op ongeveer dezelfde wijze als voor de douglas door Jansen et al. (2016). In plaats van de opperhoogte is de gemiddelde hoogte opgenomen, en de dominante hoogte en dominante diameter ontbreken. De tabellen zonder dunning missen uiteraard dunning-gegevens.

\section{Lijnbeplantingen}

Bij de analyses zijn alle lijnbeplantingen voorzien van hypothetische areïeke kenmerken maar in de tabellen worden lineïeke kenmerken gepresenteerd, dus bij voorbeeld lopende volumebijgroei in $\mathrm{m}^{3} \mathrm{~km}^{-1} \mathrm{jr}^{-1}$.

Voor een groot aantal van deze gegevens kunnen de gevonden relaties in de voorafgaande hoofdstukken worden gebruikt. Maar er zullen nog wat andere kenmerken worden gebruikt.

\subsection{Overige kenmerken}

\subsubsection{Opstandvolume}

In de data zijn de boomvolumes bepaald met het Schumacher-Hall-model (1933):

$$
v=d^{c_{37}} \cdot h^{c_{38}} \cdot e^{c_{39}} \text { met } d \text { in } \mathrm{cm}, h \text { in m en } v \text { in } \mathrm{dm}^{3}
$$

Voor populier (Faber \& Tiemens, 1975) geldt $c_{37}=1.7886, c_{38}=1.1060$ en $c_{39}=-3.0719$. In de basisgegevens is het opstandvolume bepaald door de afzonderlijke boomvolumes op te tellen.

Formule (45) is niet geschikt om het opstandvolume te bepalen. In het verleden werd gebruik gemaakt van de gemodificeerde opstandvolumefunctie van Heisterkamp (1981), de functie luidt:

$$
\begin{aligned}
V= & c_{40} \cdot G^{c_{41}} \cdot h_{\text {top }}^{\left(c_{42}+c_{43} \cdot t_{0}\right)} \text { met } G \text { in } \mathrm{m}^{2} / \text { ha, } h_{\text {top }} \text { in } \mathrm{m} \text { en } V \text { in } \mathrm{m}^{3} / \text { ha } \\
& \text { met } t_{0}=t-t_{1.30}
\end{aligned}
$$

Voor populier is deze functie gefit met $h_{m}$ in plaats van $h_{\text {top }}$ :

$$
y=V_{b t}+V_{a t}=c_{40} \cdot h_{m}^{c_{42}} \cdot\left(G_{b t}^{c_{41}}+G_{a t}^{c_{41}}\right)
$$

Met een $R^{2}$ van 0.991 is gevonden: $c_{40}=0.8606, c_{41}=1.0123$ en $c_{42}=0.4701$. 
De formule van Heisterkamp is ontwikkeld voor opbrengsttabellen die een startwaarde hadden voor de hoogte. Voor populier is die $c_{52}=7 \mathrm{~m}$. Daar beneden moet met de Formule (45) worden gewerkt.

In de opbrengsttabellen wordt het opstandvolume dus bepaald met:

$$
V= \begin{cases}N \cdot v_{g} \approx N \cdot d_{g}^{c_{33}} \cdot h_{m}^{c_{34}} \cdot e^{c_{35}} & \text { for } h_{m} \leq c_{39} \\ c_{40} \cdot G^{c_{41}} \cdot h_{m}^{c_{42}} & \text { for } h_{m}>c_{39}\end{cases}
$$

\subsubsection{Hoogte bij Laagdunning voor Trilpopulier.}

Voor trilpopulier worden er opbrengsttabellen gemaakt met laagdunning. In alle voorgaande modellen betreft de hoogte steeds de gemiddelde hoogte, die door een systematische dunning niet wordt beïnvloed. Nu moet de hoogte voor dunning en na dunning worden geschat. Daarnaast is de opperhoogte geschat met:

$$
h_{\text {top }}=c_{43} \cdot h_{m}^{c_{44}}
$$

Met een $R^{2}$ van 0.971 is gevonden: $c_{43}=1.5329$ en $c_{44}=0.8878$.

$$
\begin{aligned}
& h_{b t}=c_{45} \cdot h_{m} \\
& h_{a t}=c_{46} \cdot h_{m}
\end{aligned}
$$

Er waren slechts 16 waarnemingen met dunning aanwezig en de parameters zijn met een gewogen gemiddelde als volgt geschat:

$$
\begin{aligned}
\hat{c}_{45}= & \frac{\sum_{i=1}^{16} n_{b t i} \cdot h_{b t i}}{\sum_{i=1}^{16} n_{m i} \cdot h_{m i}}=\frac{\sum_{i=1}^{16} n_{b t i} \cdot h_{b t i}}{\sum_{i=1}^{16}\left\{\frac{n_{b t i}+n_{a t i}}{2} \cdot \frac{h_{b t i}+h_{a t i}}{2}\right\}} \\
\hat{c}_{46}= & \frac{\sum_{i=1}^{16} n_{a t i} \cdot h_{a t i}}{\sum_{i=1}^{16} n_{m i} \cdot h_{m i}}=\frac{\sum_{i=1}^{16} n_{a t i} \cdot h_{a t i}}{\sum_{i=1}^{16}\left\{\frac{n_{b t i}+n_{a t i}}{2} \cdot \frac{h_{b t i}+h_{a t i}}{2}\right\}} \\
& \text { where } n_{b t} \text { and } n_{a t} \text { are the real number of trees before and after thinning }
\end{aligned}
$$

Gevonden werd $c_{45}=0.9878$ en $c_{46}=1.0087$.

\subsubsection{Diameter van dunning.}

De diameter voor, na en van de dunning zijn bij een systematische dunning aan elkaar gelijk. Voor de laagdunning bij de trilpopulier wordt de diameter van de dunning indirect bepaald, doordat zowel het grondvlak als stamtal voor en na dunning bepaald worden. 


\subsubsection{Beginstamtal}

Voor de bospercelen is een plantverband van $5 \times 5 \mathrm{~m}$ aangehouden, dus $N_{0}=400 \mathrm{ha}^{-1}$. Voor de korte omloop plantages is een plantverband van $2 \times 2 \mathrm{~m}$ aangehouden, dus $N_{0}=$ $2500 \mathrm{ha}^{-1}$.

In de lijnbeplantingen is een boomafstand van $3.2 \mathrm{~m}$ aangehouden, dus $N_{0}=312 \mathrm{~km}^{-1}$. In het opbrengsttabelmodel is $\mathrm{N}_{0}$ voor tabellen met dunning weergegeven door de parameter $c_{50}$ en voor tabellen zonder dunning als $c_{51}$.

\subsection{Opbrengsttabellen}

\subsubsection{Keuze voor berekende opbrengsttabellen}

Allereerst is gekozen welke tabellen gepubliceerd zullen worden. Er is gekozen voor drie opbrengsttabel voor Nederland:

1. Voor populieren cultivars in lijnbeplantingen met plantafstand $3.2 \mathrm{~m}$, vijf boniteiten zonder dunning;

2. Voor populieren cultivars in bosbeplantingen met plantafstanden 4, 5, 6, 8 en $10 \mathrm{~m}$, vijf boniteiten met en zonder systematische dunning;

3. Voor populieren cultivars in bosbeplantingen met plantafstand $10.2 \times 10.2 \mathrm{~m}$, vijf boniteiten met systematische dunning

4. Voor populieren cultivars in biomassaplantages met plantafstand $2 \times 2 \mathrm{~m}$, boniteiten I tot en met III zonder dunning;

5. Voor trilpopulier met plantafstand $2 \times 2 \mathrm{~m}$, met vijf boniteiten en met matige laagdunning.

Tabel 23. Leeftijdsinterval in dataset per type, soort, dunningmethode en boniteit.

Table 23. Age interval in the data set per type, species, thinning method and site class

\begin{tabular}{|c|c|c|c|c|c|c|c|}
\hline \multirow[b]{2}{*}{ Type } & \multirow[b]{2}{*}{ Soort } & \multirow[b]{2}{*}{ Beheersysteem } & \multicolumn{5}{|c|}{ Boniteit } \\
\hline & & & I & II & III & IV & V \\
\hline \multirow{2}{*}{ weg } & \multirow{2}{*}{ cultivars } & zonder dunning & $19-22$ & $25-37$ & $21-56$ & $8-24$ & \\
\hline & & systematische dunning & $17-31$ & $15-59$ & $8-61$ & $8-48$ & $10-48$ \\
\hline \multirow{5}{*}{ bos } & \multirow{4}{*}{ cultivars } & zonder dunning & $2-38$ & $2-48$ & $4-52$ & $4-40$ & $6-35$ \\
\hline & & systematische dunning & $6-35$ & $2-39$ & $4-42$ & $4-33$ & $7-21$ \\
\hline & & laagdunning & $6-37$ & & & & \\
\hline & & met sterfte & $2-24$ & $2-15$ & $1-17$ & & \\
\hline & esp & matige laagdunning & $9-22$ & $13-32$ & $15-30$ & 45 & $41-54$ \\
\hline
\end{tabular}

In Tabel 24 is de verdeling over boniteiten en leeftijdsklassen gegeven voor het aantal opstanden in de $4^{\mathrm{e}}$ Bosstatistiek met een hoogte $\geq 10 \mathrm{~m}$. Dit geeft de behoefte aan tabellen weer, terwijl Tabel 23 een indicatie van de mogelijkheden geeft. 
Tabel 24. Leeftijdsklassen per boniteit in $4^{\mathrm{e}}$ Bosstatistiek (aantal opstanden met $\boldsymbol{h}_{m} \geq 10$ ).

Table 24. Age classes per site class in Fourth National Forest Inventory (number of stands with $h m>10 \mathrm{~m}$ ).

\begin{tabular}{|c|c|c|c|c|c|c|}
\hline \multirow[b]{2}{*}{ leeftijdsklasse } & \multicolumn{5}{|c|}{ Boniteit } & \multirow[b]{2}{*}{ Totaal } \\
\hline & $\leq 1$ & II & III & IV & $\geq V$ & \\
\hline $15-20$ & 374 & 433 & 668 & 350 & 174 & 1999 \\
\hline $20-25$ & 169 & 417 & 637 & 338 & 253 & 1814 \\
\hline $25-30$ & 40 & 202 & 281 & 198 & 181 & 902 \\
\hline $30-35$ & 7 & 88 & 158 & 129 & 74 & 456 \\
\hline $35-40$ & 1 & 19 & 47 & 35 & 21 & 123 \\
\hline $40-45$ & & 12 & 14 & 13 & 12 & 51 \\
\hline $45-50$ & & 4 & 4 & 7 & 4 & 19 \\
\hline $50-45$ & & 3 & 7 & 7 & & 17 \\
\hline $55-60$ & & 2 & 2 & & & 4 \\
\hline Totaal & 591 & 1180 & 1818 & 1077 & 719 & 5385 \\
\hline
\end{tabular}

Extrapolatie buiten het waarnemingsmateriaal moet in principe beperkt worden maar is onvermijdelijk (zie Tabel 23). Per opbrengsttabel is in Tabel 25 de maximale leeftijd per boniteiten weergegeven. Voor populier in bos en in lijnbeplantingen is alleen de versie met systematische dunning weergegeven, voor de versies zonder dunning kan de tabel eerder stoppen in verband met noodzakelijke eindkap bij verwachte sterfte.

Tabel 25. Maximale leeftijd per opbrengsttabel en boniteit.

Table 25. Maximum age per yield table and site class.

\begin{tabular}{|l|ccccc|}
\hline & \multicolumn{5}{|c}{ Boniteit } \\
Opbrengsttabel & I & II & III & IV & V \\
\hline Populier, lijnbeplanting met systematische dunning & 40 & 50 & 60 & 60 & 60 \\
Populier, bos met systematische dunning & 40 & 45 & 50 & 50 & 50 \\
Populier, biomassa plantage met sterfte & 13 & 13 & 13 & & \\
Trilpopulier met matige laagdunning & 35 & 35 & 35 & 45 & 55 \\
\hline
\end{tabular}

\subsubsection{Constructie van de opbrengsttabel}

Voor de constructie van een opbrengsttabel worden eerst bij een gekozen waarde voor $h_{25}$ (zie Tabel 9a, b en c in Hoofdstuk 3) de $S$-waarde berekend met de reciproke van Formule (16a) en het bij de dunninggraad behorende $S \%$ van Hart met Formule (1) vastgesteld. Verder is het beginstamtal $N_{0}$ afgeleid van het plantverband, dus 400 voor populierenbos, 2500 voor de korte omloop variant en voor de trilpopulier, 312 voor lijnbeplantingen. Daarna zijn per leeftijd $t$ op het interval $\left\{1, t_{\max }+1\right\}$ een aantal variabelen berekend. Allereerst wordt $h_{m}$ berekend met Formule (16).

Er worden drie situaties onderscheiden:

I. $h_{m}<7 \mathrm{~m}$. Geen dunning. 
Het stamtal is gelijk aan $N_{0}$ (in het model is deze $c_{50}$ ). De $d_{g}$ wordt met Formule (21) berekend. Voor het grondvlak volgt $G_{b t}=N_{0} \cdot \frac{\pi}{40000} \cdot d_{g}^{2}$. Het volume wordt met Formule (48) berekend. Voor de grondvlak- en volume bijgroei is de berekening hetzelfde als bij situatie III.

Tot een hoogte van $1.30 \mathrm{~m}$ worden alleen het stamtal en de gemiddelde hoogte vermeld;

II. $h_{m(t)} \leq 7 \mathrm{~m}$ en $h_{m(t+1)}>7 \mathrm{~m}$

Allereerst wordt de $t_{7}$ bepaald (de exacte leeftijd waarop een gemiddelde hoogte van $7 \mathrm{~m}$ wordt bereikt met de inverse van Formule (16). Het deel van de grondvlakbijgroei tot $t_{7}$ wordt berekend met een aangepast versie van Formule (21):

$$
\begin{gathered}
i_{G}\left(t, t_{7}\right)=N_{0} \cdot\left(g_{7}-g_{t}\right)=N_{0} \cdot \frac{\pi}{4} \cdot d_{7}^{2} \cdot\left[1-\left\{\frac{\exp \left(-c_{9} \cdot e^{-c_{10} \cdot(h-1.30)}\right)}{\exp \left(-c_{9} \cdot e^{-c_{10} \cdot(7-1.30)}\right)}\right\}^{2}\right] \\
\text { where } d_{7}=c_{6}+c_{7} \cdot s p_{\max } \\
s p_{\max }= \begin{cases}s p_{0} & \text { for } s p_{0} \leq c_{8} \\
c_{8} & \text { for } s p_{0}>c_{8}\end{cases}
\end{gathered}
$$

Voor het tweede deel van de grondvlakbijgroei, moet eerst het S\% worden bepaald met $N=N_{a t}(t-1)$ en $h_{\text {top }}=7$ met Formule (1) berekend, daaruit volgt de dunninggraad voor dunning volgt $\operatorname{Tg} r=(S \%-10) / 3$. De grondvlakbijgroei wordt nu met een aangepaste versie van Formule (23) berekend:

$$
\begin{aligned}
& i_{G}\left(t_{7}, t+1\right)=c_{11} \cdot h_{25}^{c_{12}} \cdot \operatorname{cor}_{5 \%} \cdot\left\{c_{16} \cdot T_{h}+\left(1-c_{16}\right) \cdot T_{t}\right\} / d t \quad \text { for } h_{1}>7 \\
& \text { where } \operatorname{cor}_{5 \%}= \begin{cases}1 & \text { for } S \% \leq c_{14} \\
1-c_{13} \cdot\left(S \%-c_{14}\right)^{c_{15}} & \text { for } S \%>c_{14}\end{cases} \\
& T_{h}=\left(h_{t+1}-1.30\right)^{c_{17}}-(7-1.30)^{c_{17}} \text { and } T_{t}=\left(t_{2}-t_{130}\right)^{c_{17}}-\left(t_{7}-t_{130}\right)^{c_{17}} \\
& d t=t+1-t_{7} \\
& S \%=\text { Hart Becking spacing index at } t_{1} \text {, see Formula } 1 \\
& t_{130}= \begin{cases}1.30 \cdot t_{0} / h_{0} & \text { for poplar } \\
\frac{\ln \left\{1-(1.3 / S)^{1 / c_{2}}\right\}}{-c_{1}} & \text { for aspen }\end{cases}
\end{aligned}
$$

$\mathrm{Na}$ het bepalen van beide delen $I_{G}$ wordt het grondvlak voor dunning op het tijdstip $t+1$ bepaald:

$$
G_{b t(t+1)}=G_{b t(t)}+i_{G}\left(t, t_{7}\right) \cdot\left(t_{7}-t\right)+i_{G}\left(t_{7}, t+1\right) \cdot\left(t+1-t_{7}\right)
$$

De berekening gaat nu verder als bij situatie III

III. $h_{\text {top }}>7 \mathrm{~m}$. Dit is de situatie waarin gedund kan worden. 
Het stamtal voor dunning op tijdstip $t=t$ is gelijk aan het stamtal na dunning op het tijdstip $t=t-1$. Het grondvlak voor dunning is ook bekend, omdat dit op ieder tijdstip een jaar vooruit wordt berekend - de eerste keer met Formule (53) en (54), en later met (56) en (57).

Met de gemiddelde hoogte op $t=t$ en $N_{b t}$ wordt actuele dunninggraad (S\%) met formule (1) berekend.

Met de reciproke van de grondvlakdefinitie wordt de diameter voor dunning berekend:

$$
d_{b t}=200 \cdot \sqrt{\frac{G_{b t}}{\pi \cdot N_{b t}}}
$$

Op ieder tijdstip wordt verder het volume voor dunning $V_{b t}$ berekend met Formule (48). Alleen bij veelvouden van 5 jaar mag er gedund worden, daartussendoor vindt er wel bijgroei plaats, maar wordt er niet gedund en geldt "de situatie na dunning is gelijk aan die voor dunning".

Er zijn nu zes keuzeregels voor dunning/eindkap:

1. Voor de tabel Populier bos met systematische dunning Indien $S \%$ voor dunning $<20.5$ wordt $50 \%$ van stamtal gedund, $d_{a t}=d_{t h}=d_{b t}, h_{a t}=h_{t h}=$ $h_{b t}, N_{a t}=N_{t h}=1 / 2 N_{b t}, G_{a t}=G_{t h}=1 / 2 G_{b t}$ en $V_{a t}=V_{t h}=1 / 2 V_{b t}$. En $S \%$ na dunning wordt berekend.

2. Voor de tabel Populier bos zonder systematische dunning Indien S\% voor dunning < 17.5 wordt de tabel na deze regel niet langer voortgezet, explicit betreft dit dus de eindkap.

3. Voor de tabel Populier biomassaplantage met systematische dunning Indien $S \%$ voor dunning $<20.5$ wordt 50\% van stamtal gedund, $d_{a t}=d_{t h}=d_{b t}, h_{a t}=h_{t h}=$ $h_{b t}, N_{a t}=N_{t h}=1 / 2 N_{b t}, G_{a t}=G_{t h}=1 / 2 G_{b t}$ en $V_{a t}=V_{t h}=1 / 2 V_{b t}$. En $S \%$ na dunning wordt berekend.

4. Voor de tabel Populier lijnbeplanting met systematische dunning Indien $S \%$ voor dunning $<14.5$ wordt $50 \%$ van stamtal gedund, $d_{a t}=d_{t h}=d_{b t}, h_{a t}=h_{t h}=$ $h_{b t}, N_{a t}=N_{t h}=1 / 2 N_{b t}, G_{a t}=G_{t h}=1 / 2 G_{b t}$ en $V_{a t}=V_{t h}=1 / 2 V_{b t}$. En $S \%$ na dunning wordt berekend.

5. Voor de tabel Populier lijnbeplanting zonder dunning Indien S\% voor dunning < 11.5 wordt de tabel na deze regel niet langer voortgezet, explicit betreft dit dus de eindkap.

6. Voor de tabel Trilpopulier met zeer sterke laagdunning Het gewenst S\% bedraagt $25 \%$ het daarbij gewenste stamtal na dunning wordt berekend met $N_{a t}=\left(\frac{10000}{25 \cdot h_{m}}\right)^{2}$. Indien het gewenste stamtal $N_{a t}$ kleiner is dan $N_{b t}$ wordt er gedund. De diameter na dunning dat wordt berekend met Formule (41), dus $d_{a t}=d_{b t} \cdot\left\{R \cdot \frac{a_{a t}}{a_{b t}}+1-R\right\}$ waarbij geldt $R=c_{31}$. 
Voor het grondvlak na dunning volgt $G_{a t}=N_{a t} \cdot \pi \cdot\left(d_{a t} / 200\right)^{2}$, voor dat van de dunning geldt $G_{t h}=G_{b t}-G_{a t}$, evenzo $N_{t h}=N_{b t}-N_{a t}$ en $d_{t h}=200 \cdot \sqrt{G_{t h} /\left(\pi \cdot N_{t h}\right)}$. De gemiddelde hoogte voor, na en van dunning zijn hetzelfde. Het volume voor en na dunning wordt berekend met Formule (48) en het verschil tussen beide waarden is het volume van de dunning

Alle relevante informatie van de situatie met en zonder dunning is nu bekend en alvorens naar een volgend jaar te gaan wordt de grondvlakbijgroei tot het volgende jaar $t=t+1$ met de uit Formule (23) afgeleide volgende formule berekend:

$$
\begin{gathered}
I_{G}(t, t+1)=c_{11} \cdot h_{40}^{c_{12}} \cdot \operatorname{cor}_{5 \%} \cdot\left\{c_{16} \cdot T_{h}+\left(1-c_{16}\right) \cdot T_{t}\right\} \\
\text { where } T_{h}=\left(h_{t+1}-1.30\right)^{c_{17}}-\left(h_{t}-1.30\right)^{c_{17}} \text { and } T_{t}=\left(t+1-t_{130}\right)^{c_{17}}-\left(t-t_{130}\right)^{c_{17}} \\
\operatorname{cor}_{5 \%} \text { and } t_{130} \text { as in Formula } 54
\end{gathered}
$$

Het $S \%$ in Formule (56) is het actuele $S \%$ na eventuele dunning. Na het bepalen van $I_{G}$ wordt het grondvlak voor dunning op $t=t+1$ bepaald:

$$
G_{b t(t+1)}=G_{a t(t)}+I_{G}(t, t+1)
$$

Verder wordt er een telwerk bijgehouden van het grondvlak en volume van de uitgevoerde dunningen en wordt het totaal geproduceerde volume berekenend met $V_{\text {tot }}=V_{a t}$ $+\Sigma V_{t h}$, evenzo $G_{t o t}=G_{a t}+\Sigma G_{t h}$. Alle resultaten worden per leeftijd opgeslagen, daarna worden de gemiddelde en lopende volumebijgroei berekend met

$$
\begin{aligned}
& \operatorname{ImV}=\frac{V_{t o t(t)}}{t} \\
& I C V=\frac{V_{t o t(t+1)}-V_{t o t(t-1)}}{2}
\end{aligned}
$$

Op vergelijkbare wijze worden de gemiddelde en lopende bijgroei van het grondvlak berekend.

In Paragraaf 6.3 wordt de kwaliteit van het ontwikkelde model beoordeeld. In Paragraaf 6.4 worden enkele eigenschappen van de uiteindelijk tabellen vergeleken met andere opbrengsttabellen. In Bijlage 1 zijn de geproduceerde opbrengsttabellen weergegeven. Hierna volgt nog een tabel met alle parameters.

In deze Tabel 26 komen de parameters $c_{47}, c_{48}$ en $c_{49}$ pas in Paragraaf 6.6 aan de orde in Formule (61). 
Tabel 26. Lijst met parameters.

Table 26. List with parameters.

\begin{tabular}{|c|c|c|c|c|c|c|}
\hline $\begin{array}{l}\text { para- } \\
\text { meter }\end{array}$ & formule & bos & $\begin{array}{l}\text { boom- } \\
\text { weide }\end{array}$ & biomassa & $\begin{array}{c}\text { lijn- } \\
\text { beplanting }\end{array}$ & $\begin{array}{c}\text { tril- } \\
\text { populier }\end{array}$ \\
\hline$c_{1}$ & $(16 / 16 a)$ & 0.0792991 & 0.0792991 & 0.0792991 & 0.0522527 & 0.1126169 \\
\hline$c_{2}$ & $(16 / 16 a)$ & 1.4744760 & 1.4744760 & 1.4744760 & 1.0339029 & 1.4744760 \\
\hline$c_{3}$ & (16) & & & 0.1395504 & & \\
\hline$c_{4}$ & (16) & & & 0.1473802 & & \\
\hline$c_{5}$ & (16) & & & 3.3086647 & & \\
\hline$c_{6}$ & (21) & 7.2415115 & 7.2415115 & 7.2415115 & 7.2415115 & 7.2415115 \\
\hline$c_{7}$ & (21) & 0.9174946 & 0.9174946 & 0.9174946 & 0.9174946 & 0.9174946 \\
\hline$c_{8}$ & (21) & 3.8168994 & 3.8168994 & 3.8168994 & 3.8168994 & 3.8168994 \\
\hline$c_{9}$ & (21) & 3.1055377 & 3.1055377 & 3.1055377 & 3.1055377 & 3.1055377 \\
\hline$C_{10}$ & (21) & 0.3523936 & 0.3523936 & 0.3523936 & 0.3523936 & 0.3523936 \\
\hline$c_{11}$ & (23) & 3.8076667 & 3.8076667 & & & 3.8076667 \\
\hline$c_{12}$ & (23) & 0.5217543 & 0.5217543 & & & 0.5217543 \\
\hline$c_{13}$ & (23) & 0.0230233 & 0.0230233 & & & 0.0230233 \\
\hline$C_{14}$ & (23) & 29.1239557 & 29.1239557 & & & 29.1239557 \\
\hline$c_{15}$ & (23) & 0.8324239 & 0.8324239 & & & 0.8324239 \\
\hline$c_{16}$ & (23) & 0.5537234 & 0.5537234 & & & 0.5537234 \\
\hline$c_{17}$ & (23) & 0.4030508 & 0.4030508 & & & 0.4030508 \\
\hline$C_{18}$ & (30) & & & 1.9824409 & & \\
\hline$C_{19}$ & (30) & & & 2.6989237 & & \\
\hline$c_{20}$ & (30) & & & 0.0370773 & & \\
\hline$c_{21}$ & (30) & & & 29.2339698 & & \\
\hline$c_{22}$ & (30) & & & 0.3617466 & & \\
\hline$c_{23}$ & (30) & & & 0.7463977 & & \\
\hline$C_{24}$ & (30) & & & 1.0175848 & & \\
\hline$c_{25}$ & (39) & & & & 0.0448713 & \\
\hline$c_{26}$ & (39) & & & & 0.9192197 & \\
\hline$c_{27}$ & (39) & & & & 2.1833959 & \\
\hline$C_{28}$ & (39) & & & & 0.2148350 & \\
\hline$c_{29}$ & (39) & & & & 1.5630644 & \\
\hline$c_{30}$ & & & 63.6558950 & & & $\equiv b_{16}$ in (26) \\
\hline$c_{31}$ & (41) & & & & & 0.3287095 \\
\hline$c_{32}$ & (43) & & & 405.9037125 & & \\
\hline$c_{33}$ & (43) & & & 18.7182591 & & \\
\hline$c_{34}$ & (43) & & & -8.6136930 & & \\
\hline$c_{35}$ & (43) & & & 13.4781667 & & \\
\hline$c_{36}$ & (44) & & & 0.1094051 & & \\
\hline$c_{37}$ & (48) & 1.7886490 & 1.7886490 & 1.7886490 & 1.7886490 & 1.7886490 \\
\hline$c_{38}$ & (48) & 1.1059700 & 1.1059700 & 1.1059700 & 1.1059700 & 1.1059700 \\
\hline$c_{39}$ & (48) & -3.0719171 & -3.0719171 & -3.0719171 & -3.0719171 & -3.0719171 \\
\hline$c_{40}$ & (48) & 0.8606480 & 0.8606480 & 0.8606480 & 0.8606480 & 0.8606480 \\
\hline$C_{41}$ & (48) & 1.0123272 & 1.0123272 & 1.0123272 & 1.0123272 & 1.0123272 \\
\hline$C_{42}$ & (48) & 0.7400628 & 0.7400628 & 0.7400628 & 0.7400628 & 0.7400628 \\
\hline$C_{43}$ & (49) & & & & & 1.5327788 \\
\hline$C_{44}$ & (49) & & & & & 0.8877815 \\
\hline$c_{45}$ & (50) & & & & & 0.9876775 \\
\hline$C_{46}$ & (50) & & & & & 1.0087018 \\
\hline$C_{47}$ & (61) & & & & 0.9215519 & \\
\hline$C_{48}$ & (61) & & & & 0.1891690 & \\
\hline$C_{49}$ & (61) & & & & 0.2125694 & \\
\hline$c_{50}$ & & 400 & 96 & 2500 & 312.5 & 2500 instelbaar \\
\hline$c_{51}$ & & 400 & 96 & 2500 & 312.5 & 2500 instelbaar \\
\hline$c_{52}$ & & 7 & 7 & 7 & 7 & 7 grenswaarde $h$ \\
\hline
\end{tabular}




\subsection{Kwaliteit van de voorspelling}

Om de kwaliteit van het opbrengsttabelmodel te beoordelen moet de ontwikkeling van bestaande opstanden worden voorspeld en vergeleken met de gemeten verandering. Het ontwikkelde groeimodel van Paragraaf 6.2 om opbrengsttabellen te maken moet daartoe gemodificeerd worden tot een "stand projection model".

Van een bepaalde opstand moet de leeftijd, de opperhoogte, het stamtal en het grondvlak bekend zijn, waarmee alle andere toestandvariabelen kunnen worden berekend. Daarna kan de situatie over een aantal jaren voorspeld worden en een dunning worden gesimuleerd, en de veranderingen in de opstandkenmerken worden voorspeld. Door dit voor de proefperken (zowel van die van de dataset als die van de controle-set) te doen kan de modelvoorspelling worden vergeleken met de gemeten kenmerken. Het "stand projection model" werkt als volgt:

\section{Stap 1. Boniteit bepalen}

Allereerst moet met de reciproke van Formule (16), de leeftijd, $h_{m}, t_{0}$ en $h_{0}$ de site index $S$ worden bepaald:

$$
\begin{gathered}
S=\frac{h_{m}-h_{0}}{c o r \cdot\left\{1-e^{-c_{1} \cdot\left(t-t_{0}\right)}\right\}^{b}} \quad \text { (59) } \\
\text { where } c o r= \begin{cases}1 & \text { for roadside plots and other plots with thinning } \\
1 & \text { for other plots without thinning and } s p_{0} \geq c_{5} \\
1-c_{4} \cdot\left(c_{5}-s p_{0}\right) & \text { for other plots without thinning and } s p_{0}<c_{5}\end{cases} \\
b= \begin{cases}c_{2} & \text { for roadside plots and other plots with thinning } \\
c_{2} & \text { for other plots without thinning and } s p_{0} \geq c_{5} \\
c_{2}-c_{3} \cdot\left(c_{5}-s p_{0}\right) & \text { for other plots without thinning and } s p_{0}<c_{5}\end{cases} \\
s p_{0}=\text { the initial spacing } \\
h_{0} \text { and } t_{0} \text { are respectively the height and age of the cuttings, } \\
\text { if those values are unknown } h_{0}=1.5 \mathrm{~m} \text { and } t_{0}=2 \mathrm{yr} \\
\text { and for Aspen: } h_{0}=0 \mathrm{~m} \text { and } t_{0}=0 \mathrm{yr}
\end{gathered}
$$

\section{Stap 2.}

Met de definitie van de Formules (1) wordt vervolgens het $S \%$ voor en na dunning bepaald. De grondvlakbijgroei per jaar worden berekend met de waarden voor $\operatorname{Tg} r, h_{\text {top }}, h_{50}$ en $t$ over het interval $\left\{t_{1} ; t_{2}\right\}$. In Paragraaf 6.2 is beschreven welke formules daartoe gebruikt worden. Hieruit volgt het grondvlak voor dunning op tijdstip $t_{2}$ en hieruit weer de diameter voor dunning $\left(\hat{d}_{b t 2}\right)$. 


\section{Stap 3.}

Hierna wordt de gemiddelde hoogte berekend op het $2^{\mathrm{e}}$ tijdstip met Formule (16). De voorspelde diameterbijgroei op het interval $\left\{t_{1}, t_{2}\right\}$ bedraagt:

$$
\Delta_{d}=\hat{d}_{b t 2}-d_{a t 1}
$$

Er worden evenveel bomen gedund als in werkelijkheid maar $d_{a t}=d_{t h}=d_{b t}$, behalve voor trilpopulier, daar wordt de diameter na dunning $\left(\hat{d}_{a t 2}\right)$ berekend met Formule (41).

\section{Vervolg}

Stap 2 en 3 kunnen nu herhaald worden voor een $3^{e}$ tijdstip en eventuele vervolgtijdstippen. De stamtallen van de dunning en die voor en na dunning zijn bekend, hiermee en met de formules uit het opbrengsttabel model kunnen alle andere opstandkenmerken worden berekend.

Om de kwaliteit van het model te meten is deze procedure voor series van 4 opnamen doorgerekend (veel perken hebben echter maar 3 opnamen, daar is met 3 opnamen gewerkt, enkele perken hebben maar 2 opnamen en zijn niet meegenomen in de berekening). Voor bijvoorbeeld een perk met 6 opnamen ontstaan zo drie voorspellingseries op de intervallen $\left\{t_{1}\right.$, $\left.t_{4}\right\},\left\{t_{2}, t_{5}\right\}$ en $\left\{t_{3}, t_{6}\right\}$. Vervolgens is de zuiverheid en nauwkeurigheid van de voorspellingen van de bereikte opperhoogte, de diameter na dunning en het opstandgrondvlak na dunning in de laatste (dus de $3^{\mathrm{e}}$ of $4^{\mathrm{e}}$ ) opname bekeken. Het gemiddelde tijdvak bedroeg 6.1 jaar.

Daarnaast werd de grondvlakbijgroei over 10 jaar bekeken (zie Tabel 27 voor de resultaten).

De onzuiverheid van alle berekende voorspellingen blijkt gering tot matig, variërend van 0.1 $\%$ onderschatting tot $2.8 \%$ overschatting. De nauwkeurigheid van de schatting van de grondvlakbijgroei is gering. Bij de berekening zijn alleen opnamen geselecteerd met aangepaste leeftijd van 4 jaar en ouder, omdat jongere opnamen bij de snelgroeiende variëteiten een te grote afwijkende boniteit voorspelde, indien deze opnamen wel werden meegenomen was er sprake van $9.1 \%$ overschatting van de grondvlakbijgroei en een variatiecoëfficiënt van $44.6 \%$.

Tabel 27. Eigenschappen van enige schatters.

Table 27. Properties of some predictions.

\begin{tabular}{|l|rrrrrr|}
\hline & gesultaten bij laatste opname \\
& gemeten & geschat & bias & bias\% & st.dev & vC \\
\hline$h_{m}$ & 22.30 & 22.43 & -0.130 & $-0.58 \%$ & 1.749 & $7.8 \%$ \\
$d_{a t}$ & 33.67 & 33.72 & -0.050 & $-0.15 \%$ & 1.995 & $5.9 \%$ \\
$G_{a t}$ & 18.00 & 17.99 & 0.016 & $0.09 \%$ & 2.480 & $13.8 \%$ \\
$i G_{10}$ & 12.79 & 13.14 & -0.354 & $-2.77 \%$ & 4.048 & $31.7 \%$ \\
\hline
\end{tabular}




\subsection{Vergelijking met andere opbrengsttabellen}

In deze paragraaf worden enkele andere opbrengsttabellen voor de populier in Europa vergeleken met het hier gevonden resultaat.

Van de landen waarvoor opbrengsttabellen voor populierenvariëteiten beschikbaar zijn, zijn er 5 geschikt om te vergelijken: die van Crocoll (1954) voor 'Marilandica' en Rätzel (1969) voor 'Robusta', beide voor Zuid-Duitsland, in de door Schober (1987) bewerkte versie, die van Hamilton en Christie (1971) voor Groot-Brittannië en die van Van Laar (1957) en Faber en Tiemens (1975) voor Nederland.

Er is één tabel voor trilpopulier gevonden (zie Paragraaf 6.7) en ook één voor lijnbeplantingen van populier (zie Paragraaf 6.6).

\subsubsection{Hoogteontwikkeling}

De diverse auteurs van de te vergelijken opbrengsttabellen hanteren niet allen dezelfde maat voor de hoogte: meestal wordt de gemiddelde hoogte gebruikt, soms de opperhoogte. Hiervoor is niet gecorrigeerd in de figuren 28 tot en met 31.

De vorm van de hoogtecurven bij de tabel van Van Laar (1957) komen zeer goed overeen met die van de nieuwe tabel voor Nederland. Van Laar heeft maar 2 boniteiten, waarvan de $1^{\mathrm{e}}$ boniteit overeenkomt met de $3^{\mathrm{e}}$ van de nieuwe tabel en de $2^{\mathrm{e}}$ met de $4^{\mathrm{e}}$ van de nieuwe tabel (zie figuur 28).

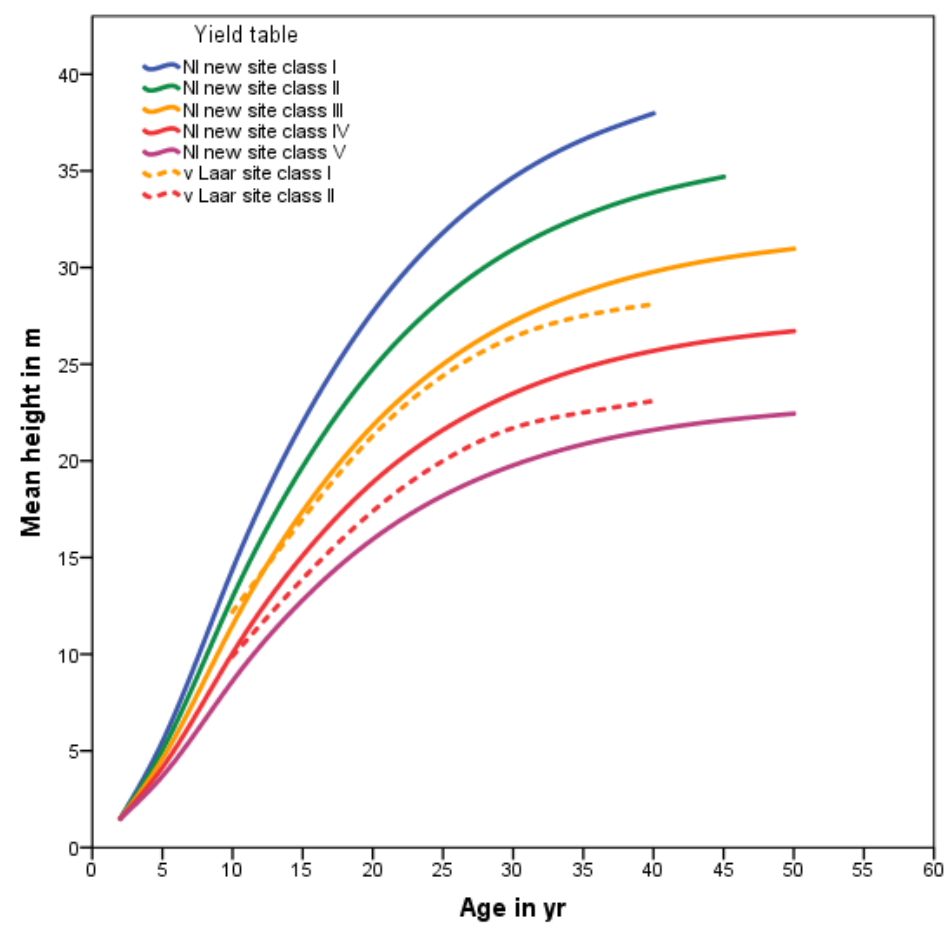

Figuur 28. Hoogteontwikkeling bij van Laar en het nieuwe model voor Nederland.

Figure 28. Height development at van Laar's yield table and the new model for Netherlands. 
De vorm van de hoogtecurven komen bij Faber en Tiemens (1975) tot 25 jaar zeer goed overeen met die van de nieuwe tabel, daarna vlakken die van de nieuwe tabel eerder af. De nieuwe tabel heeft nog een lagere boniteit dan Faber en Tiemens (zie Figuur 29).

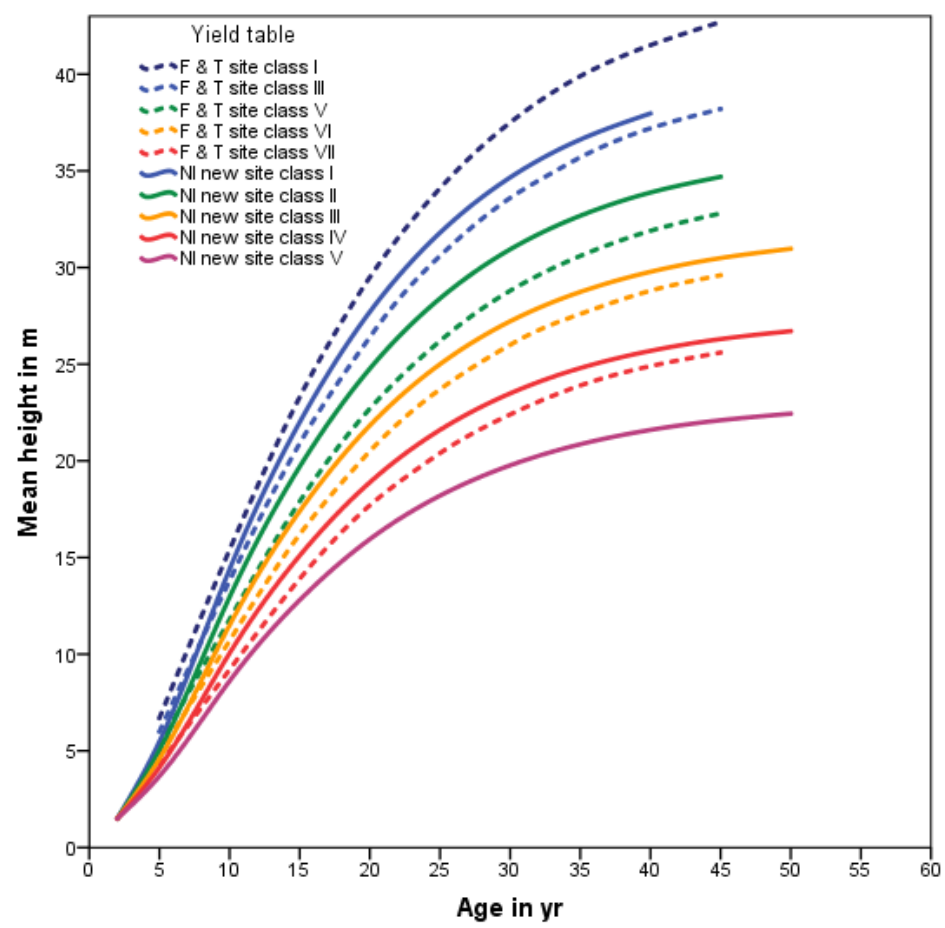

Figuur 29. Hoogteontwikkeling bij Faber \& Tiemens en het nieuwe model voor Nederland. Figure 29. Height development at Faber \& Tiemens' yield table and the new model for Netherlands.

Voor Duitsland komt de vorm van de enige hoogtecurve bij de tabel van Crocoll (1954) slecht overeen met die van curven in de nieuwe tabel voor Nederland. De vorm van de hoogtecurven komen echter bij Rätzel (1969) zeer goed overeen met die van de nieuwe tabel. De nieuwe tabel heeft nog drie lagere boniteit dan Rätzel (zie Figuur 30). 


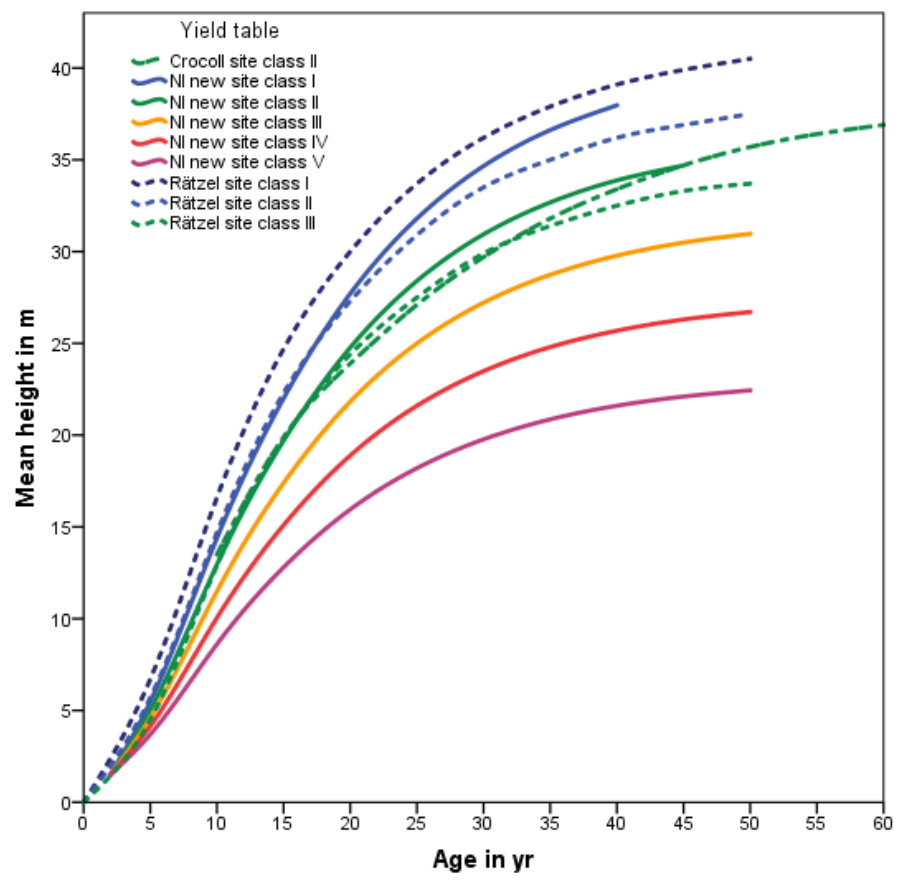

Figuur 30. Hoogteontwikkeling bij Crocoll en Rätzel en het nieuwe model voor Nederland.

Figure 30. Height development at Crocoll's and at Rätzel's yield table and the new model for Netherlands.

Bij de vergelijking met de tabel van Hamilton \& Christie (1971) voor Groot-Brittannië blijkt de vorm van de curven slecht overeen te komen met die van de nieuwe tabel voor Nederland. De curven zijn er steiler en van afplatting is nog geen sprake, wel kont het totale bereik redelijk overeen (zie Figuur 31).

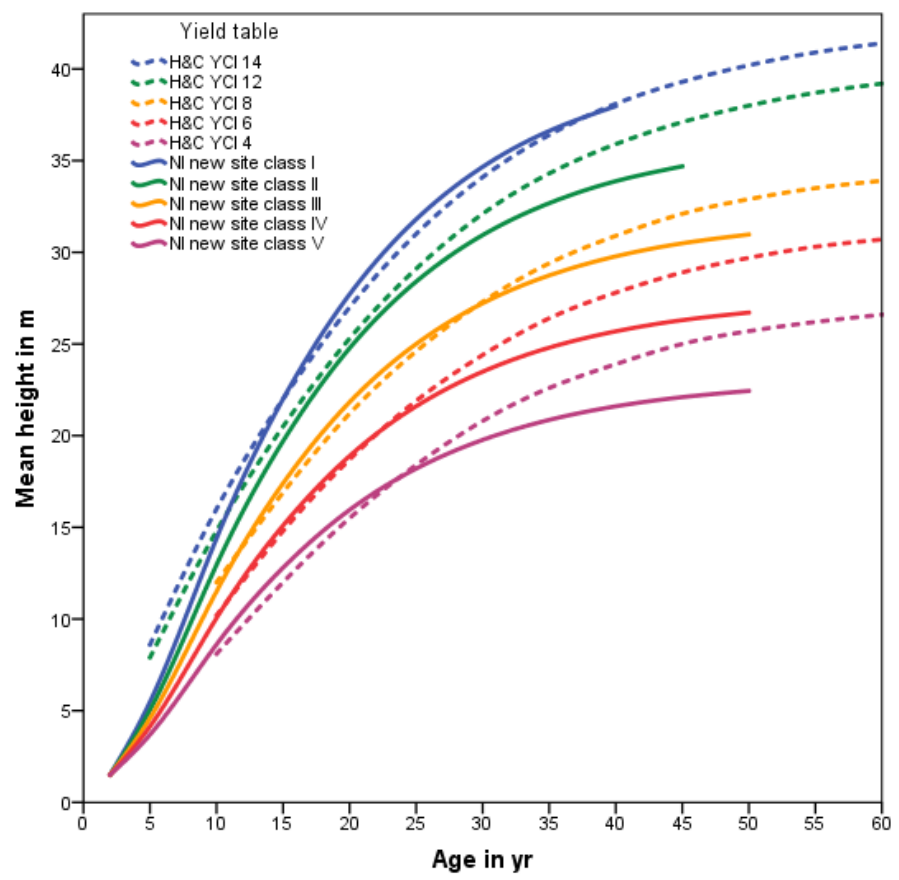

Figuur 31. Hoogteontwikkeling bij Hamilton \& Christie en het nieuwe model voor Nederland

Figure 31. Height development at Hamilton \& Christie's yield table and the new model for Netherlands. 
Voor Zweden zijn geen opbrengsttabellen gevonden, maar wel een model voor de hoogteontwikkeling van Johansson (2013).

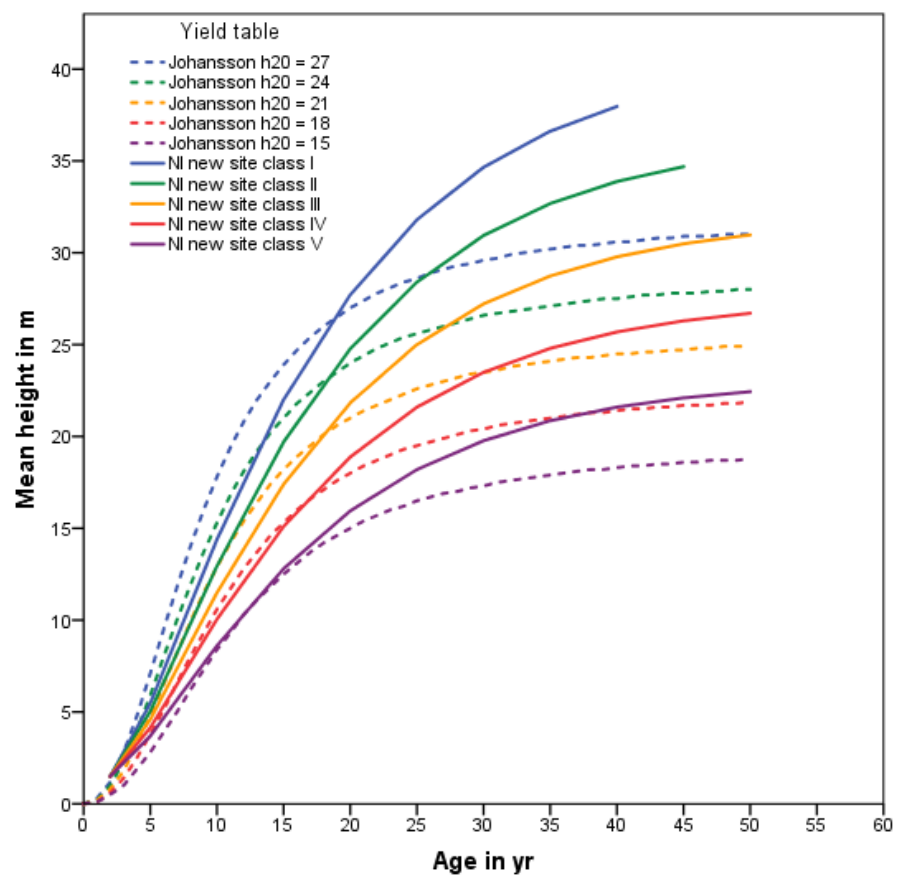

Figuur 32. Hoogteontwikkeling bij Johansson en het nieuwe model voor Nederland

Figure 32. Height development at Johansson's yield table and the new model for Netherlands.

Bij de vergelijking met model van Johansson (2013) voor Zweden blijkt de vorm van de curven zeer slecht overeen te komen met die van de nieuwe tabel voor Nederland. Het traject tot borsthoogte duurt veel langer, daarna zijn de curven er steiler tot 20 jaar, waarna de afplatting snel inzet (zie Figuur 32) en er sprake van een heteromorf model.

De hoogteontwikkeling bij de vergeleken tabellen lijkt, behoudens bij Hamilton \& Christie en de curven van Johansson redelijk overeen te komen met het in deze studie gevonden model.

\subsubsection{Productieniveau}

Het productieniveau wordt bij voorkeur gemeten op basis van de gemiddelde volumebijgroei bij zekere leeftijd. Hier is echter naar de totale grondvlakproductie gekeken.

Een probleem bij de vergelijking is verschil in het plantverband en in de wijze van dunning.

Crocoll (1954) gaat uit laagdunning en een beginstamtal van 400.

Rätzel (1969) gaat uit laagdunning en een beginstamtal van 400.

Hamilton \& Christie (1971) geven een tabel zonder dunning met een beginstamtal van 185. Van Laar (1957) geeft een tabel zonder dunning met een beginstamtal van 160. 


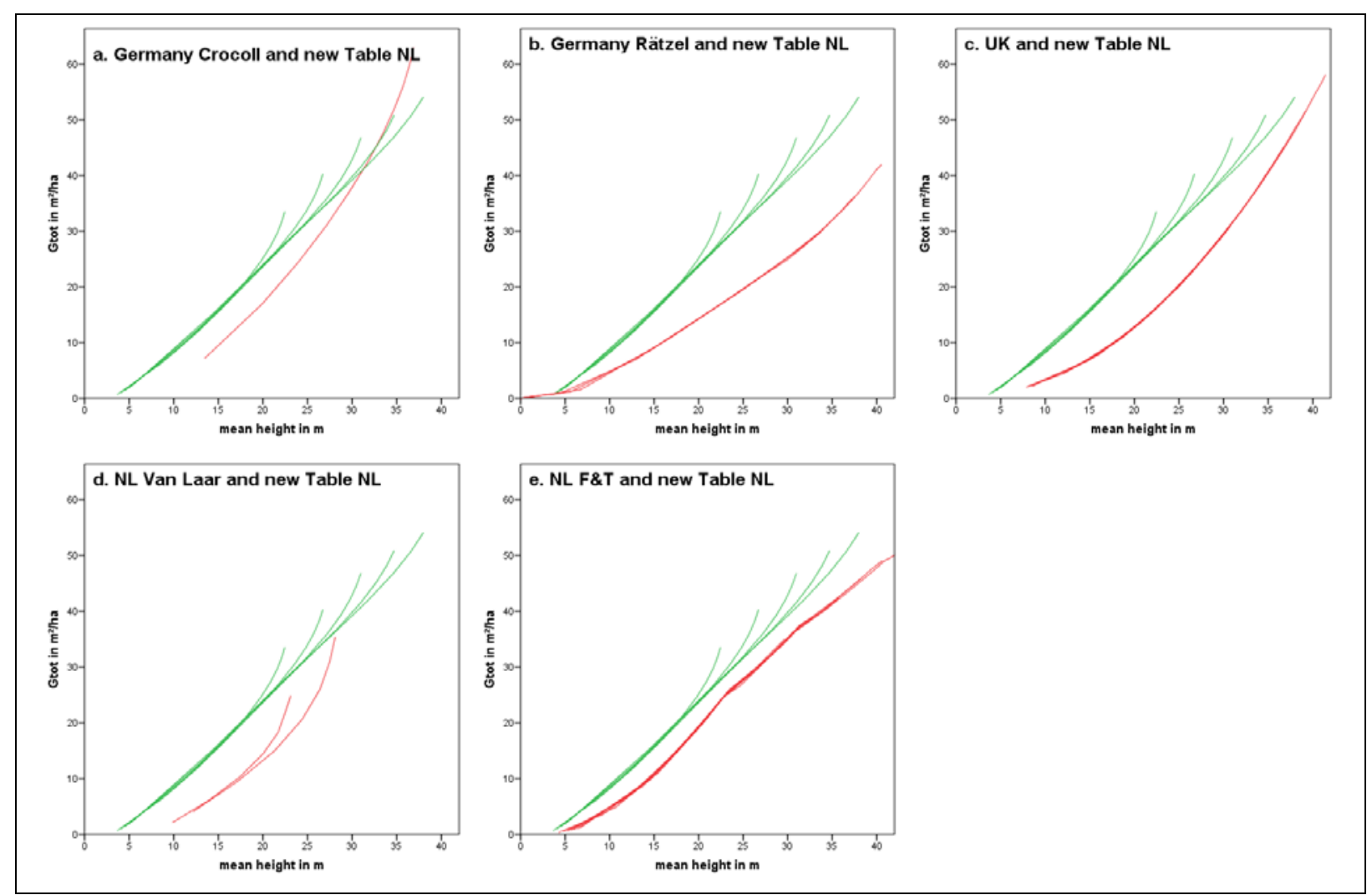

Figuur 33. De totale grondvlakproductie Gtot in relatie tot de opperhoogte bij de nieuwe tabel voor Nederland (in groen) in vergelijking met andere opbrengsttabellen (in rood) voor a. Crocoll, b. Rätzel, c. Hamilton \& Christie, d. van Laar en e. Faber \& Tiemens.

Figure 33. Total basal area production Gtot in relation to top height for the new table for the Netherlands (in green) in comparison with other yield tables (in red) from a. Crocoll, b. Rätzel, c. Hamilton \& Christie, d. van Laar and e. Faber \& Tiemens.

Faber \& Tiemens (1975) geven tabellen met en zonder systematische dunning met een beginstamtal van 625, 278, 156 en 100. Maar ze geven formules om bij andere beginstamtallen een tabel te berekenen, hier is gekozen voor de tabel met systematische dunning en een plantverband van $5 \times 5$ meter $\left(N_{\circ}=400\right)$

De nieuwe tabel gaat uit van systematische dunning en beginstamtal van 400 .

In Figuur 33 is de totale grondvlakproductie per opbrengsttabel uitgezet tegen de gemiddelde hoogte voor alle boniteiten. De meeste opbrengsttabellen hebben als startpunt een hoogte van ongeveer 5 à $8 \mathrm{~m}$, en de nieuwe tabel vanaf een leeftijd 5 jaar.

Volgens de "uitgebreide wet van Eichhorn" (Gehrhardt, 1909) zouden bij een presentatie van $V$ tot in relatie tot $h_{\text {top }}$ alle boniteitlijnen over elkaar moeten vallen, dat geldt dan ook min of meer voor Gtot. Alle modellen behalve Van Laar en het nieuwe model voldoet hieraan.

De overeenkomst met de beide Duitse tabellen is ondanks hetzelfde beginstamtal zeer gering. Het productieniveau bij Van Laar en Hamilton \& Christie is uiteraard lager door de wijde stand maar de vorm komt redelijk overeen.

De curves bij Faber \& Tiemens komen wat betreft de vorm goed overeen met die van de nieuwe tabel, het niveau ligt gemiddeld $5.7 \mathrm{~m}^{2} \mathrm{ha}^{-1}$ lager dan in de nieuwe tabel. 


\subsubsection{Dunningsysteem}

Jansen et al. (1996) dunnen in hun bewerking van de 'Robusta'-tabel van Faber en Tiemens (1975) 50\% van de bomen zodra het grondvlak boven $24 \mathrm{~m}^{2} \mathrm{ha}^{-1} \mathrm{komt}$, en in hun tabellen zonder dunning vindt eindkap plaats na het bereiken van een grondvlak van $36 \mathrm{~m}^{2} \mathrm{ha}^{-1}$. Van Laar (1957) en Hamilton \& Christie (1971) passen geen dunning toe en bij Van Laar (1957) vindt de eindkap plaatst bij 40 jaar en bij Hamilton \& Christie (1971) bij 60 jaar. In de opbrengsttabel van Crocoll (1954) voor 'Marilandica' vindt laagdunning plaats met een dunninggraad "open stand", in de tabel van Rätzel (1969) voor 'Robusta' wordt een zeer zware laagdunning gebruikt.

Het in de nieuwe tabel voor Nederland gebruikte dunningsysteem komt dus het meest overeen met dat van Faber en Tiemens, maar het beslissingscriterium is niet het grondvlak, maar het $S \%$.

\subsection{Effecten plantverband op productie}

Volgens de gangbare opvatting in het bosbeheer zullen opstanden met een ruimer plantverband ten opzichte van opstanden met een dichter plantverband onder overige gelijke omstandigheden:

1. Een geringere volume- en grondvlakbijgroei hebben;

2. Een grotere diameter hebben.

In Figuur 34 wordt het eerste punt gedemonstreerd met de gemiddelde volumebijgroei. Te zien is voor een eerste boniteit bij een plantverband van $5 \times 5 \mathrm{~m}$ in gedunde opstanden een gemiddelde volumebijgroei hebben van $16.4 \mathrm{~m}^{3} \mathrm{ha}^{-1} \mathrm{jr}^{-1}$ bij $40 \mathrm{jr}$. Het stamtal bedraagt dan na 2 dunningen 100 stuks per ha. Maar als de opstand met een plantverband van $10 \times 10 \mathrm{~m}$ was aangelegd hadden die 100 bomen per ha na 40 jaar een gemiddelde volumebijgroei hebben bereikt van $12.1 \mathrm{~m}^{3} \mathrm{ha}^{-1} \mathrm{jr}^{-1}$. Met een kwart van het aantal bomen wordt dus $73 \%$ van de volumeproductie bereikt, daarmee wordt uiteraard aan het tweede punt voldaan. In Figuur 35 wordt dat verder verduidelijkt. Met het plantverband van $5 \times 5$ m bedraagt na 2 dunningen de diameter van de overgebleven 100 bomen na 2 dunningen bij een leefijd van 40 jaar $52.6 \mathrm{~cm}$, maar indien met een plantverband van $10 \times 10 \mathrm{~m} 100$ bomen worden aangelegd dan zijn deze na 40 jaar $68.0 \mathrm{~cm}$ dik.

Doordat er sparake is vrij grote dunningingrepen zijn de lijnen in Figuur 35 niet vloeiend. 

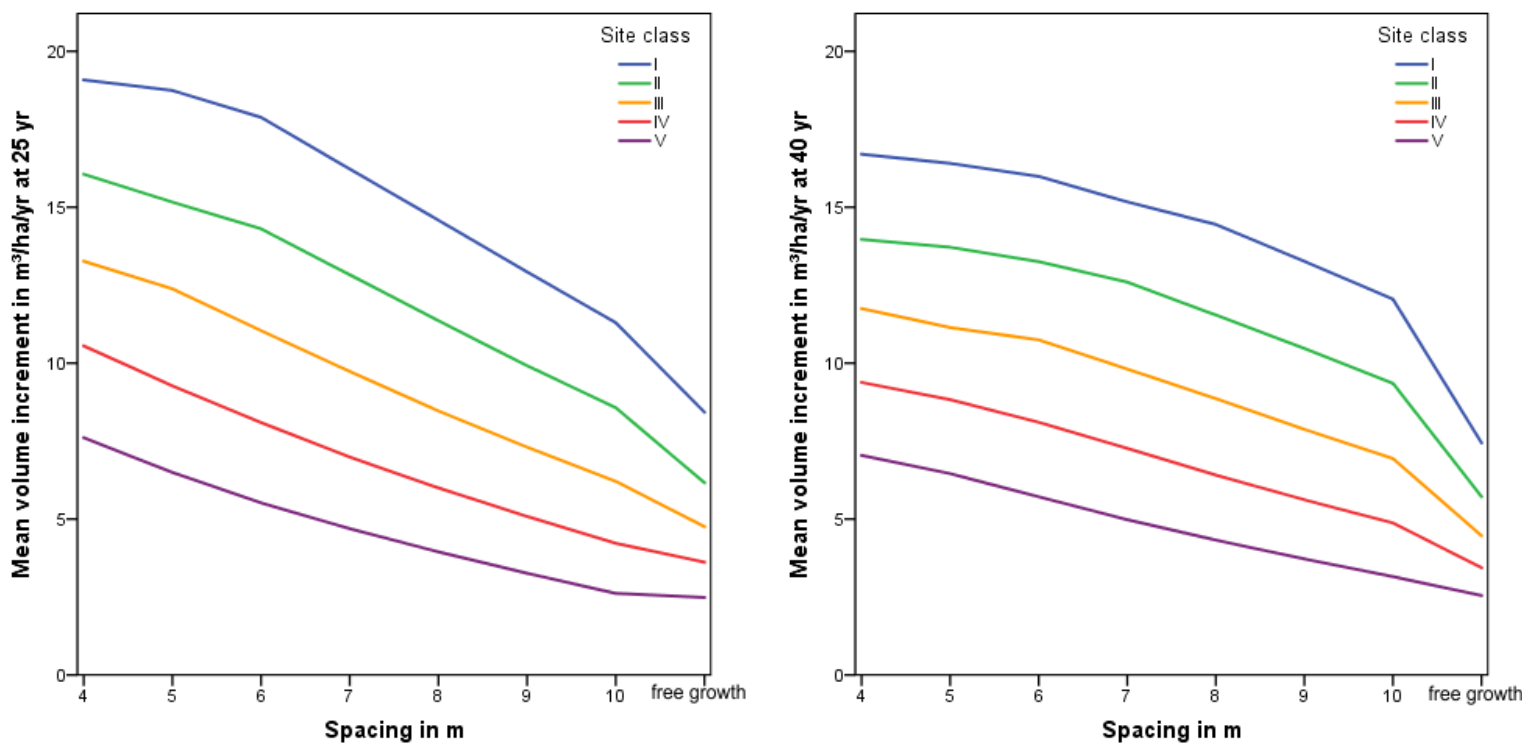

Figuur 34. Relatie tussen gemiddelde volumebijgroei in $\mathrm{m}^{3} \mathrm{ha}^{-1} \mathrm{jr}^{-1}$ op $\mathbf{2 5}$ jaar (links) en $\mathbf{4 0}$ jaar (rechts) met boniteit en plantverband in $m$ en voor boomweiden.

Figure 34. Relationship between mean volume increment in $m^{3} h a^{-1} \mathrm{jr}^{-1}$ at 25 year (left) and 40 year (right) for spacing and free growth boniteit per site class.

Voor de boomweiden ( $N_{0}=96$ met een plantverband van $10.2 \times 10.2 \mathrm{~m}$ ), waarbij de groei van de individuele bomen die van solitaire bomen benadert (free growth) zijn de 12 blijvende bomen bij de $1^{\mathrm{e}}$ boniteit na 4 dunningen gemiddeld $61.8 \mathrm{~cm}$ dik op 25 -jarige leeftijd en na 40 jaar is dat $97.7 \mathrm{~cm}$. De totale volumebijgroei is uiteraard sterk gereduceerd
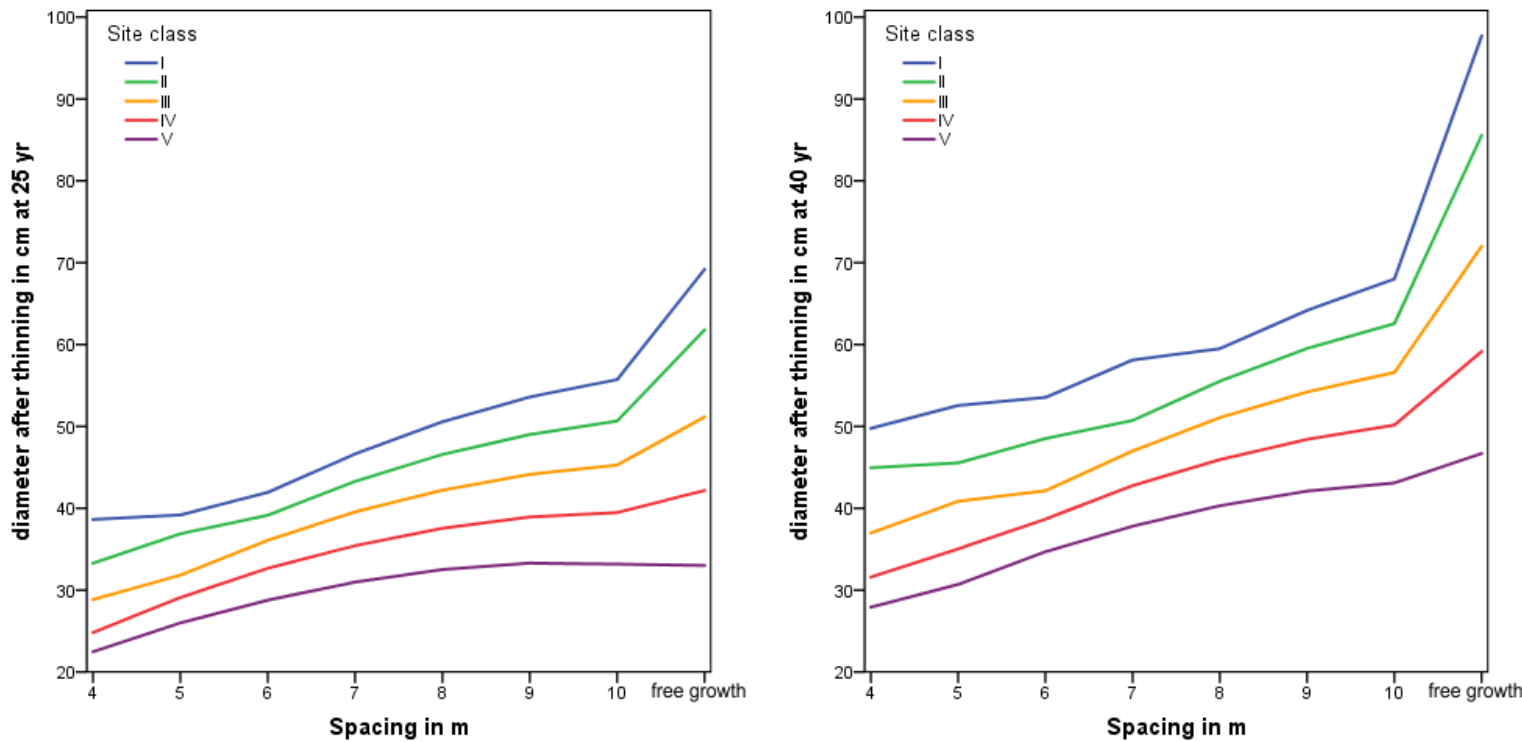

Figuur 35. Relatie tussen diameter na dunning in cm op 25 jaar (links) en $\mathbf{4 0}$ jaar (rechts) met boniteit en plantverband in $m$ en voor boomweiden (free growth).

Figure 35. Relation between diameter after thinning and thinning grade and for free growth by site class at 25 years (left) and at 40 years(right).

Voor de biomassa-tabellen is alleen de tabel met een plantafstand van 2 meter gegeven. In Figuur 36 zijn wat kencijfers gegeven voor andere plantafstanden. 

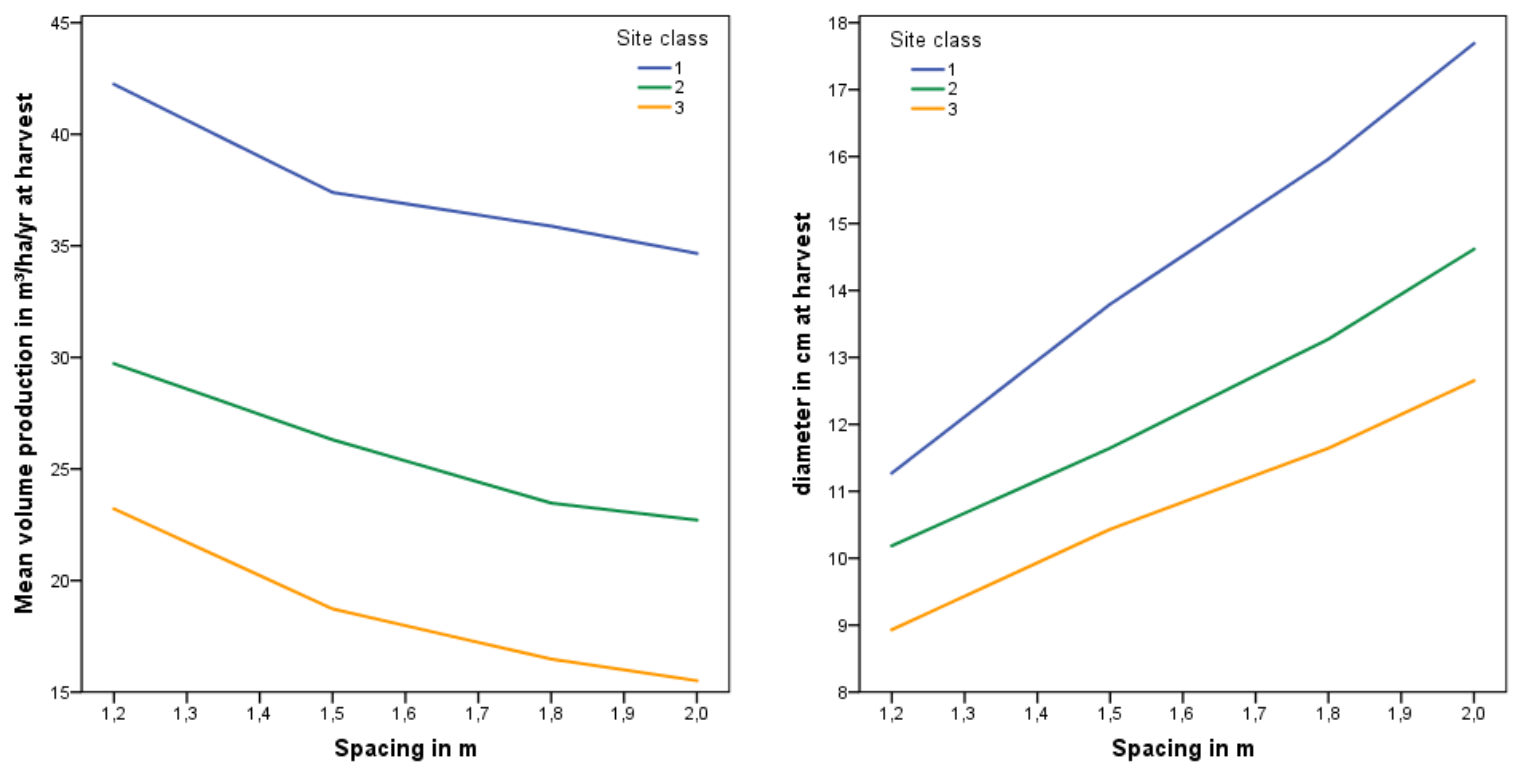

Figuur 36. Relatie tussen gemiddelde volumeproductie op tijdstip waarop grote sterfte optreedt in $\mathrm{m}^{3} \mathrm{ha}^{-1} \mathrm{jr}^{-1}$ (links) en diameter in cm op dat tijdstip (rechts) met boniteit en plantverband in $m$.

Figure 36. Relationship between mean volume increment in $\mathrm{m}^{3} h a^{-1} j r^{-1}$ at time mortality start (left) and diameter in $\mathrm{cm}$ at time mortality start (right) with site class and spacing in $\mathrm{m}$.

Bij een $\mathrm{I}^{\mathrm{e}}$ Boniteit en een plantafstand van $1.2 \mathrm{~m}$ treedt in het $9^{\mathrm{e}}$ jaar de eerste sterfte op, door daarna te oogsten wordt de grootst mogelijke productie bereikt van $42.2 \mathrm{~m}^{2} \mathrm{ha}^{-1} \mathrm{jr}^{-1}$. Hierbij is er impliciet vanuit gegaan dat het dode hout na één jaar niet meer geschikt is. De maximale lopende bijgroei bedraagt $73.9 \mathrm{~m}^{3} \mathrm{ha}^{-1} \mathrm{jr}^{-1}$ in het $7^{\mathrm{e}}$ jaar. In de data fluctueert dat met $90 \mathrm{~m}^{3} \mathrm{ha}^{-1} \mathrm{jr}^{-1}$ bij 6 jaar, $32 \mathrm{~m}^{3} \mathrm{ha}^{-1} \mathrm{jr}^{-1}$ bij 7 jaar en $76 \mathrm{~m}^{3} \mathrm{ha}^{-1} \mathrm{jr}^{-1}$ bij 8 jaar.

Bij een $\mathrm{I}^{\mathrm{e}}$ Boniteit en een plantafstand van $2.0 \mathrm{~m}$ vindt eerste sterfte plaats in het $12^{\mathrm{e}}$ jaar, maar die is nog gering en met een omloop van 13 jaar is de MMAI (maximale gemiddelde jaarlijkse bijgroei) $34.7 \mathrm{~m}^{2} \mathrm{ha}^{-1} \mathrm{jr}^{-1}$.

\subsection{Lijnbeplantingen}

Jansen (1990) geeft een voorlopige opbrengsttabel voor lijnbeplantingen van populier, hij gebruikt hiervoor dezelfde data als in onze studie. Maar op dat moment was slechts $40 \%$ van de data ontsloten. Hij presenteert alleen de gegevens voor boniteit $\mathrm{V}$, maar geeft formules en parameters voor andere boniteiten. In Figuur 37 is te zien dat de boniteitlijnen goed met elkaar overeenkomen.

De Vries (1962) en Jansen (1990) rapporteerden een verschil tussen de diameter in de rij $\left(d_{i r}\right)$ en die daar loodrecht op $\left(d_{o r}\right)$. Uit de ratio tussen $d_{i r}$ en $d_{b t}$ kunnen beide diameters als volgt worden geschat: 


$$
\begin{aligned}
d_{i r}= & d_{b t} \cdot \text { Ratio } \\
& \text { where Ratio }=\frac{d_{i r}}{d_{b t}}=c_{47}+c_{48} \cdot S \% / 1000+c_{49} \cdot h_{25} / 100 \\
d_{o r}= & \frac{d_{g}^{2}}{d_{i r}}
\end{aligned}
$$

Model (61) lijkt met een $R^{2}$ van 0.999 een goede verklaring te geven, maar dat is slechts schijn, verklaren we allen de factor Ratio uit model (61) dan bedraagt de $R^{2}$ slechts 0.159 .

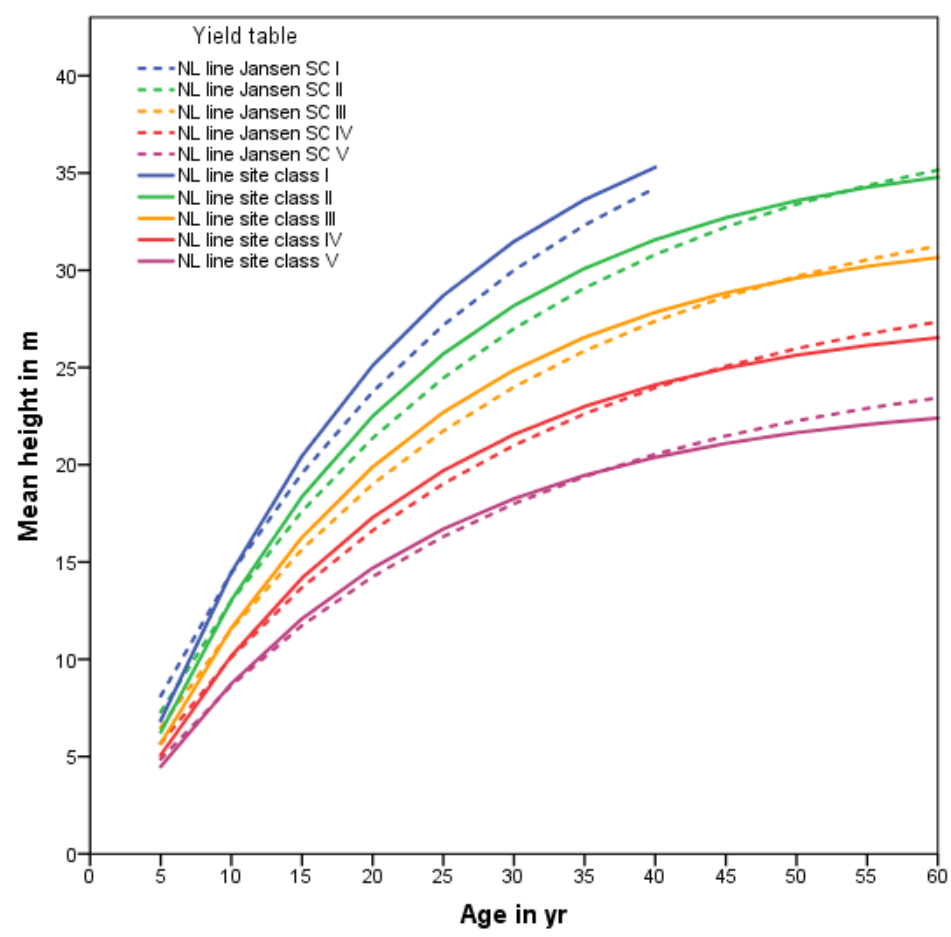

Figuur 37. Hoogteontwikkeling in lijnbeplantingen bij Jansen en het nieuwe model voor Nederland.

Figure 37. Height development in line plantations at Jansen's yield table and the new model for Netherlands.

Tabel 28 geeft de oplossing van model (61).

Tabel 28. Parameterschatting met Model (61)

Table 28. Parameter estimation with Model (61)

\begin{tabular}{|l|r|r|r|r|}
\hline & & & \multicolumn{2}{|c|}{ 95\% Confidence Interval } \\
\cline { 4 - 5 } Parameter & Estimate & Std. Error & Lower Bound & Upper Bound \\
\hline$C_{47}$ & 0.9216 & 0.011 & 0.900 & 0.943 \\
$C_{48}$ & 0.1892 & 0.071 & 0.049 & 0.329 \\
$C_{49}$ & 0.2126 & 0.040 & 0.135 & 0.290 \\
\hline
\end{tabular}




\subsection{Trilpopulier}

Er is maar één opbrengsttabel voor trilpopulier gevonden, namelijk de tabel van Misir et al. (2013) voor natuurlijke bossen in Noord en Oost Anatolië in Turkije. Ondanks dat de omgevingsfactoren niet vergelijkbaar zijn met die in Nederland, is in Figuur 38 een vergelijking gemaakt voor de hoogtegroei in beide tabellen. Van enige overeenkomst lijkt geen sprake.

Te zien is dat bij ongeveer 55 jaar de hoogte van de III ${ }^{\mathrm{e}}$ boniteit van Misir et al. overeenkomt met die van de $\mathrm{V}^{\mathrm{e}}$ boniteit van de nieuwe tabel voor Nederland, evenzo voor de $\mathrm{I}^{\mathrm{e}}$ boniteit van beide tabellen.

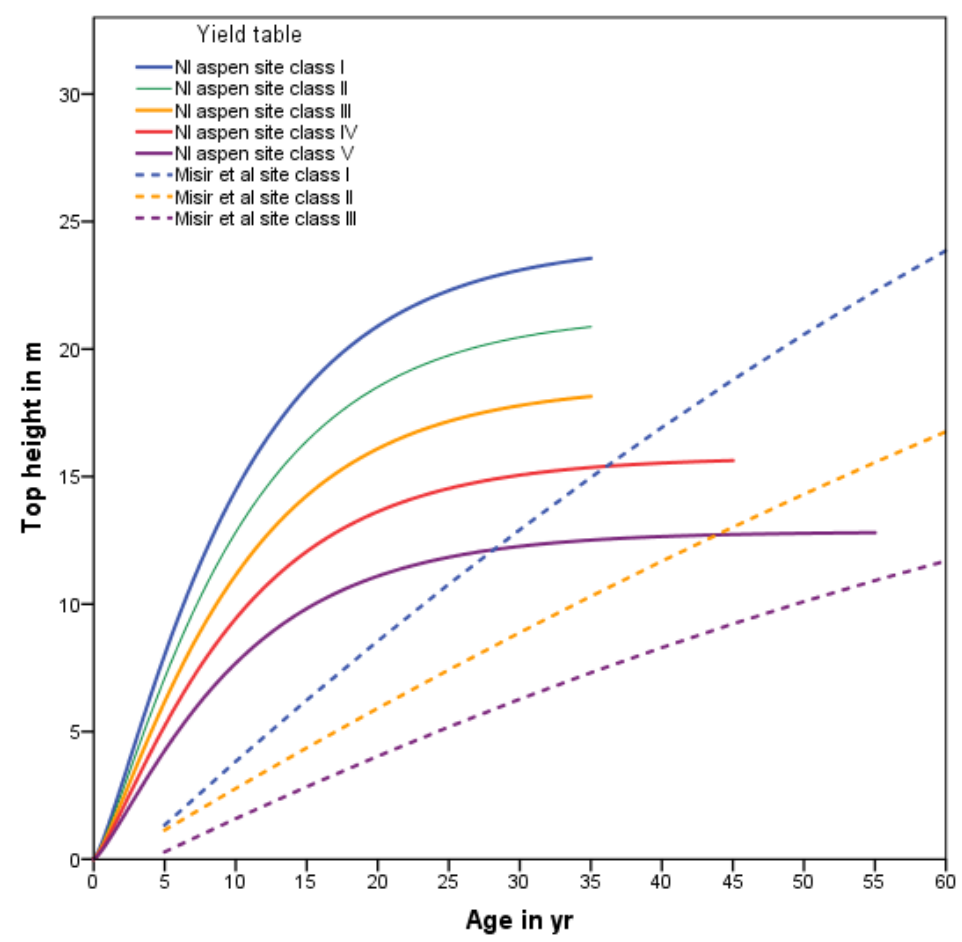

Figuur 38. Hoogteontwikkeling bij trilpopulier bij Misir et al. en het nieuwe model voor $\mathrm{Ne}$ derland.

Figure 38. Height development for aspen at yield table by Misir et al. and the new model for Netherlands. 


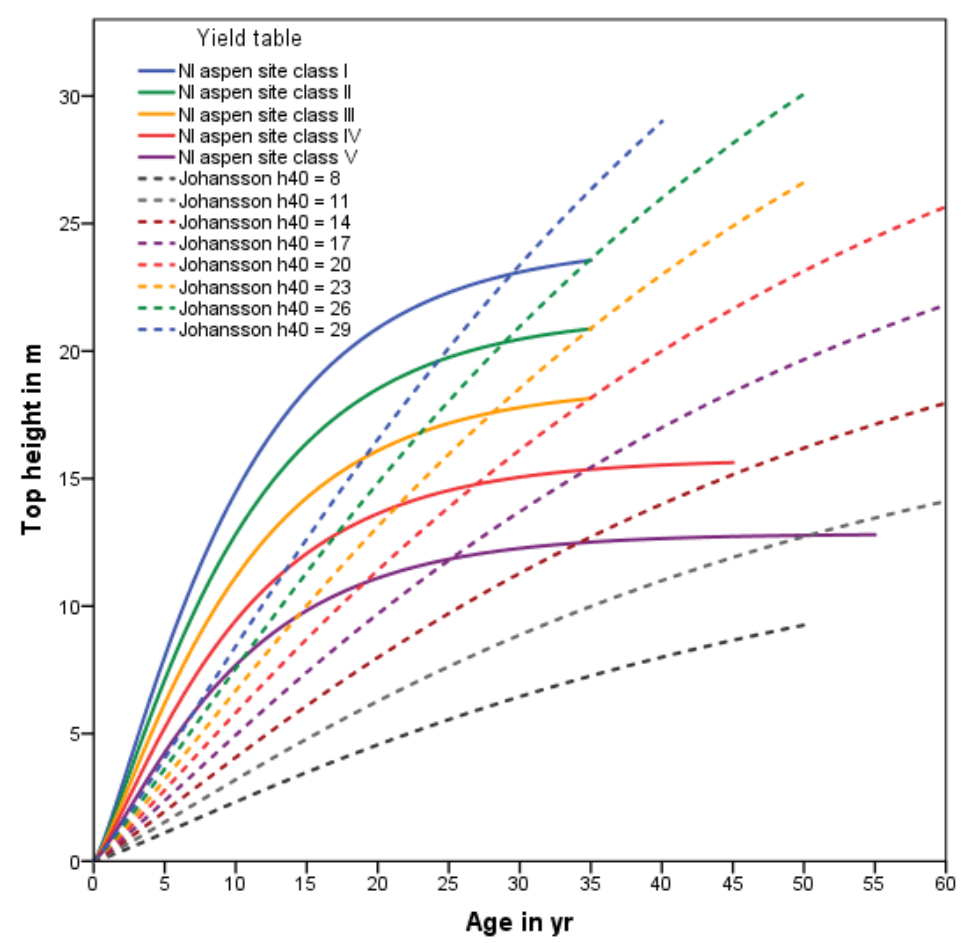

Figuur 39. Hoogteontwikkeling voor trilpopulier bij Johansson en het nieuwe model voor Nederland.

Figure 39. Height development for aspen at Johansson's yield curves and the new model for Netherlands.

Johansson (1996) geeft voor Zweden wel een set boniteringslijnen (zie figuur 39). Ook deze lijnen vertonen weinig overeenkomst met het nieuwe model voor Nederland. Van een pionierskarakter met snelle jeugdgroei en een vroege afvlakking van de groei is geen sprake. Johansson geeft 3 nog lagere boniteiten dan in de nieuwe tabel voor Nederland voorkomen. 


\section{Discussie en conclusies}

\subsection{Hoogtegroei}

De hoogteontwikkeling van de opstand is een resultante van hoogtegroei en topsterfte. Een biologisch relevant groeimodel moet een buigpunt en een asymptoot hebben. Over dat buigpunt en de asymptoot zijn kwantitatieve gegevens afgeleid daarnaast is bekend wat de leeftijd op borsthoogte moet zijn. Met nog wat aanvullende criteria zijn zes modellen getest, geen voldeed volledig aan alle criteria. Het model van Chapman-Richards (zie Pienaar \& Turnbull, 1973) voldeed het best, maar in zeer dichte stand bleek de hoogte beïnvloed door die stand. Het uiteindelijke model luidt:

$$
\begin{gathered}
h_{m}=h_{0}+\text { cor } \cdot S \cdot\left\{1-e^{-c_{1} \cdot\left(t-t_{0}\right)}\right\}^{b} \\
\text { where cor }= \begin{cases}1 & \text { for plots with thinning } \\
1 & \text { for plots without thinning and } s p_{0} \geq c_{5} \\
1-c_{4} \cdot\left(c_{5}-s p_{0}\right) & \text { for plots without thinning and } s p_{0}<c_{5}\end{cases} \\
\qquad \begin{array}{ll}
c_{2} & \text { for plots with thinning } \\
c_{2} & \text { for plots without thinning and } s p_{0} \geq c_{5} \\
c_{2}-c_{3} \cdot\left(c_{5}-s p_{0}\right) & \text { for plots without thinning and } s p_{0}<c_{5}
\end{array} \\
\qquad p_{0}=\text { the initial spacing; } c_{1} \text { till } c_{5} \text { are the estimated model parameters } \\
h_{0} \text { and } t_{0} \text { are respectively the height and age of the cuttings, } \\
\text { if those values are unknown } h_{0}=1.5 \mathrm{~m} \text { and } t_{0}=2 \mathrm{yr} \\
\text { and for Aspen: } h_{0}=0 \mathrm{~m} \text { and } t_{0}=0 \mathrm{yr}
\end{gathered}
$$

De parameters $c_{1}$ en $c_{2}$ zijn verschillend voor de groepen bos, lijnbeplanting en trilpopulier. De asymptoot, hier de site index $S$ genoemd, is een maat voor de geschiktheid van de standplaats voor de populier. Die $R^{2}$ bleek met een waarde van 0.984 lager dan voor de douglas (Jansen et al., 2016), voor de Japanse lariks (Jansen et al., 2017a) en voor de fijnspar (Jansen et al., 2017b) werd gevonden en ongeveer gelijk aan dat bij zomereik (Jansen et al., 2017c). Met een volledig onderscheid naar variëteit is de $R^{2}$ echter zeer hoog (0.995).

Voor fijnspar, douglas, zomereik en Japanse lariks bleken andere modellen de beste oplossing te leveren.

\subsection{Grondvlakontwikkeling}

In Hoofdstuk 4 is op verschillende wijze de grondvlakontwikkeling gemodelleerd. Er zijn 4 methoden onderzocht.

Voor situaties zonder dunning zijn er twee werkwijze mogelijk:

1. Door rechtstreeks het grondvlak te verklaren:

$G_{\text {tot }}=f_{1}\left(s p_{0}, h_{25}\right) \cdot f_{2}(t, h)$

Dat bleek nergens succesvol. 
2. Door de diameter te verklaren, en daarmee indirect de het grondvlak:

$$
d_{b t}=f_{1}\left(s p_{0}, h_{25}\right) \cdot f_{2}(t, h) \rightarrow G_{b t}=N_{b t} \cdot \pi \cdot\left(\frac{\hat{d}_{b t}}{200}\right)^{2}
$$

Deze werkwijze werd succesvol toegepast voor de jeugdgroei in het traject een hoogte van $7 \mathrm{~m}$, waarbij $f_{1}$ de diameter op een hoogte van $7 \mathrm{~m}$ voorstelt $\left(d_{7}\right)$ en alleen afhankelijk is van $s p_{0}$. Voor de functie $f_{2}$ bleek een Gomperz-functie in $h$ tussen de punten 1.30 en 7 $m$ de beste oplossing. Door eerst het linkerdeel van Formule (63) te schatten en daarna her rechterdeel te berekenen wordt door de niet-lineaire transformatie het Grondvlak niet zuiver geschat, van een correctiefactor voor de zuiverheid werd afgezien. Voor de een plantafstand van $3.8 \mathrm{~m}$ en wijder bedraagt $d_{7} 10.7 \mathrm{~cm}$ voor een dichtere stand treedt er pas effect op, in de biomassatabel met een plantafstand van $2 \mathrm{~m}$ is deze $16 \%$ dunner. De aangepaste variant voor de jeugdgroei luidt:

$$
d_{b t}=f_{1}\left(s p_{0}\right) \cdot f_{2}(h) \rightarrow G_{b t}=N_{b t} \cdot \pi \cdot\left(\frac{\hat{d}_{b t}}{200}\right)^{2}
$$

Ook voor lijnbeplantingen bleek model (63) bruikbaar. Terwijl er bij dichte stand in bossen met een $S \%$ beneden 14.5 meestal sterfte optreedt, blijkt een veel lager $S \%$ in de rijrichting bij lijnbeplantingen geen invloed op de groei te hebben, omdat er voldoende ruimte loodrecht op de rijrichting is om een kroon te vormen (De Vries, 1962, Jansen, 1990). Dunning blijkt daarom bij lijnbeplantingen niet zinvol, maar vond wel plaats. Met de ongedunde opstanden is rechtstreeks de grondvlakontwikkeling geschat met model (39)/(63). Dit model is een verbeterde versie van het model van Jansen (1990) en bevat in $f_{1}$ een uitdrukking om de diameter op 25 jaar te schatten uit het beginstamtal en de boniteit. Voor functie $f_{2}$ bleek een Chapman-Richards met de alleen de leeftijd geschikter dan een power-functie. Dat is niet logisch omdat hiermee een maximale diameter wordt geïntroduceerd. Bij het oplossen van functie (63) is de werkwijze van Schnute (1981) gevolgd met de referentieleeftijden $t_{130}$ en $t_{25}$. Maar anders dan bij de jeugdgroei is nu wel gezorgd voor een zuivere schatter van het grondvlak door in Formule (63) de parameters rechtstreeks in het rechterdeel te schatten dus met

$$
G_{b t}=N_{b t} \cdot \pi \cdot\left(\frac{d_{b t}}{200}\right)^{2} \text { where } d_{b t}=f_{1}\left(s p_{0}, h_{25}\right) \cdot f_{2}(t)
$$

Voor situaties met dunning zijn er eveneens 2 modellen onderzocht:

3. Door de grondvlakbijgroei te modelleren en daarmee stapsgewijs de ontwikkeling van het totale grondvlak:

$$
i_{G}=f_{1}(S \%) \cdot f_{2}\left(h_{25}\right) \cdot\left\{w \cdot \frac{F_{3}\left(h_{2}\right)-F_{3}\left(h_{1}\right)}{t_{2}-t_{1}}+(1-w) \cdot \frac{F_{3}\left(t_{2}\right)-F_{3}\left(t_{1}\right)}{t_{2}-t_{1}}\right\}
$$

where $w$ is a weight

Deze functie is succesvol toegepast in standaard situaties, dat zijn bossen met ruime stand $\left(s p_{0} \geq 3 \mathrm{~m}\right.$ ) boven de $7 \mathrm{~m}$ zowel met als zonder dunning. Een power-functie bleek voor $F_{3}$ het meest geschikt. In Figuur 33 is te zien dat de vorm van de curven van de totale grondvlakproductie van de nieuwe opbrengsttabel met bij Van Laar (1957), bij Hamilton \& 
Christie (1971) en bij Faber \& Tiemens (1975) redelijk overeenkomen. De niveaus verschillen echter onderling ten gevolge van verschillen in plantafstand.

4. De grondvlakbijgroei kon ook indirect worden geschat met behulp van een schatter voor de diameterbijgroei met Formule (26), die in vereenvoudigde vorm luidt:

$i_{d}=f_{1}(S \%) \cdot f_{2}\left(h_{25}\right) \cdot\left\{w \cdot \frac{F_{3}\left(h_{2}\right)-F_{3}\left(h_{1}\right)}{t_{2}-t_{1}}+(1-w) \cdot \frac{F_{3}\left(t_{2}\right)-F_{3}\left(t_{1}\right)}{t_{2}-t_{1}}\right\}$

De directe schatter van model $(23) /(64)$ gaf in standaard situaties een beter resultaat dan de indirecte schatter (26)/(65), maar de indirecte schatter bevatte een interessante parameter in $f_{1}$ (een correctiefactor afhankelijk van het $S \%$ ) een rol te spelen. Tot een maximum $S \%$ van ongeveer $64 \%$ bleek die correctiefactor groter te worden. Deze waarde is gebruikt om aanvullend op de groei in standaard situaties een "free growth" model te ontwikkelen voor boomweiden, in dit model wordt er gedund zodra het $S \%$ onder $64 \%$ daalt.

Voor het bepalen van de grondvlakbijgroei in dichte stand zijn Nelderplots en plots van studie 3 geselecteerd met een beginplantafstand beneden de $3 \mathrm{~m}$. Het diameterbijgroeimodel (65) gaf het beste resultaat, wel moest de $f_{1}$ functie worden herschreven tot een functie van $S_{0} \%$ in plaats van $S \%$, met $S_{0} \%=s p_{0} / h$.

\section{Free growth}

In Figuur 35 is te zien dat de diameter bij bomen in het "free growth" model extreme toeneemt ten opzichte van het vergelijkbare $10 \times 10$ plantverband. De vraag is of dit aanvullend te onderbouwen is.

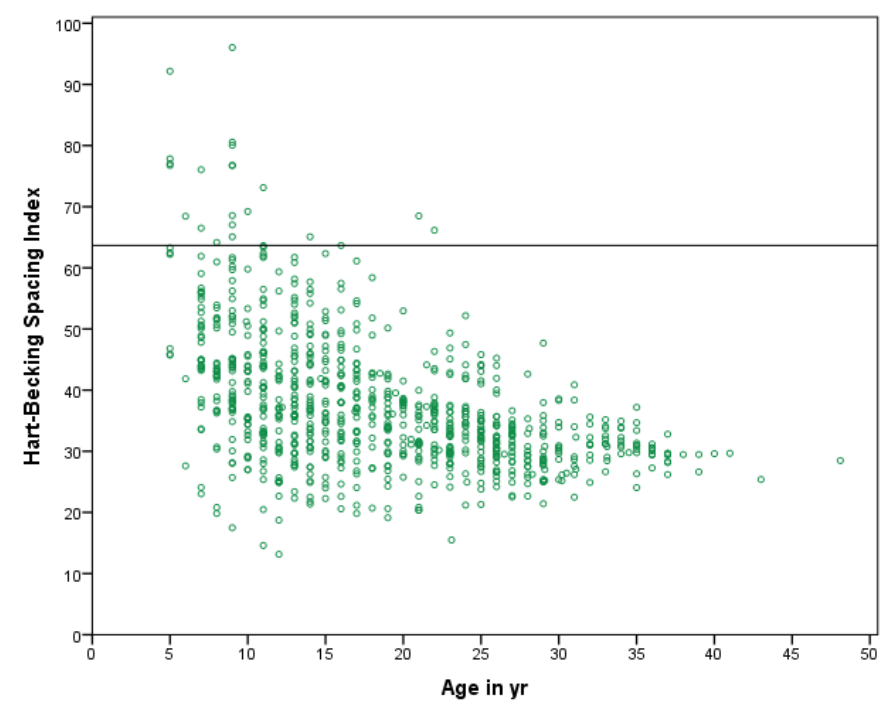

Figuur 40. S\% als functie van de leeftijd bij de plots gebruikt voor standaard situaties.

Figure $40 . \quad S \%$ as function of age at plots used for standard situations.

Helaas blijkt uit Figuur 39 dat nagenoeg alle situaties met een $S \%$ boven de $64 \%$ het relatief jong bos betreft. Overigens zijn op internet beschrijvingen van solitaire populieren met een 
diameter van ongeveer $100 \mathrm{~cm}$ wel te vinden, maar dan blijkt uit de bijgaande foto's dat de ratio kroondiameter/hoogte ongeveer 1 bedraagt wat te herleiden is voor bomen met dezelfde dimensies in een opstand tot een $S \%$ van 100 . Het gebruik van $f_{1}$ in Formule (26) voor oud bos is dus een vergaande modelextrapolatie, maar de gevonden dimensies in de simulatie "free growth" zijn niet onmogelijk.

\subsection{Variatie in groei tussen verschillende jaren}

Er is onvoldoende materiaal om een jaarindex te bepalen. Bij de douglas (Jansen et al., 2016) bleek de gemiddelde jaarindex vanaf 1981 hoger dan in de jaren ervoor. Omdat de opnamedata bij studie 2 verloren waren gegaan, bleek ook deze bevinding voor de populier niet te onderzoeken.

\subsection{Plantafstand en dunning}

De diameter blijkt per plantafstand met gemiddeld $8.8 \%$ te stijgen ten opzichte van opstanden met een plantafstand van $4 \mathrm{~m}$. Voor overige effecten van de plantafstand, zie Tabel 29.

Tabel 29. Relatieve waarden $I c_{G} I m_{G}$, en $d_{a t}$ per plantafstand $s p_{0}$ en verdwijnend stamtal en grondvlak door dunning bij III boniteit en $\mathbf{4 0} \mathbf{j r}$.

Table 29. Relative values of $I c_{G}, I m_{G}$, and $d_{a t}$ per initial spacing $s p_{0}$ and the changing stem density and basal area and by thinning at III site class and age $=40 \mathrm{yr}$.

\begin{tabular}{|r|rrr|rr|}
\hline $\boldsymbol{s}_{\boldsymbol{0}}$ & $\boldsymbol{I}_{\boldsymbol{g}}$ & $\boldsymbol{I}_{\boldsymbol{g}}$ & $\boldsymbol{d}_{\boldsymbol{a t}}$ & $\boldsymbol{N}_{\boldsymbol{t h}}$ & $\boldsymbol{G}_{\boldsymbol{t h}}$ \\
\hline 4 & $100 \%$ & $100 \%$ & $100 \%$ & $75 \%$ & $63 \%$ \\
5 & $100 \%$ & $92 \%$ & $111 \%$ & $50 \%$ & $38 \%$ \\
6 & $100 \%$ & $84 \%$ & $114 \%$ & $50 \%$ & $50 \%$ \\
7 & $100 \%$ & $77 \%$ & $127 \%$ & $0 \%$ & $0 \%$ \\
8 & $100 \%$ & $70 \%$ & $138 \%$ & $0 \%$ & $0 \%$ \\
9 & $97 \%$ & $62 \%$ & $147 \%$ & $0 \%$ & $0 \%$ \\
10 & $92 \%$ & $55 \%$ & $153 \%$ & $0 \%$ & $0 \%$ \\
\hline Free growth & $51 \%$ & $39 \%$ & $195 \%$ & $75 \%$ & $46 \%$ \\
\hline
\end{tabular}

Bij een beginstamtal hoger of gelijk aan $7 \mathrm{~m}$ is voor de standaard situatie geen dunning noodzakelijk. Het optimale plantverband is $5 \times 5 \mathrm{~m}$ met 400 poten per ha. De "free growth" betreft een modelsimulatie die de groei op een boomweide nabootst, waarbij de individuele bomen zoveel ruimte krijgen dat maximale diametergroei wordt bereikt. Uitgaande van plantverband van $10.2 \times 10.2$ meter blijven er bij de $\mathrm{I}^{\mathrm{e}}$ boniteit van de 96 stammen er uiteindelijk 12 over die dan gemiddeld bij 40 jaar bijna $98 \mathrm{~cm}$ dik zijn. Controle op de uitkomsten is onmogelijk, omdat in de bestaande 13 boomweiden er nergens zo sterk werd gedund. Ook kan niet gecontroleerd worden of er voldoende groeiruimte is, in het aangehouden dunningschema is er sprake van een kroondiameter-hoogte-ratio van $64 \%$, maar bij solitaire populieren is dat vaak $100 \%$, die overigens vaker een diameter boven de $1 \mathrm{~m}$ bereiken.

Naast de standaard situatie is er ook een tabellen-set ontwikkeld, met zeer dichte stand zonder dunning en wel met drie verschillende plantafstanden te weten 1, 1.5 en $2 \mathrm{~m}$. Deze zijn gebaseerd op de Nelderproeven en andere plantafstandproeven van studie 3. De dichtste 
stand die daar voorkwam is $1.2 \mathrm{~m}$. Er is daarbij van uitgegaan van een oogst waarbij sprake is een maximale gemiddelde grondvlakbijgroei en dat alleen hout oogstbaar is wat niet langer dan één jaar dood is. Er treden dan voor Nederland ongekend hoge waarden op in de lopende volumebijgroei. Voor de $\mathrm{I}^{\mathrm{e}}$ boniteit met een plantafstand van $1 \mathrm{~m}$ bedraagt die ruim

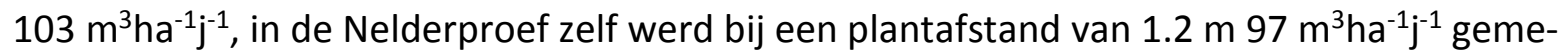
ten. We hebben geen studie gevonden, waar vergelijkbare waarden zijn gevonden. Karacic et al. (2003) vinden in hun studie met verschillende variëteiten en plantafstanden in een korte omloop experimenten een maximale gemiddelde bijgroei $22 \mathrm{~m}^{3} \mathrm{ha}^{-1} \mathrm{j}^{-1}$ voor één varieteit met een plantastand van $1 \times 2 \mathrm{~m}$ en voor de lopende bijgroei werd maximaal $50 \mathrm{~m}^{3} \mathrm{ha}$ ${ }^{1} \mathrm{j}^{-1}$ gemeten. In hun uitvoerige literatuurstudie vonden zij geen hogere waarden.

\subsection{Trilpopulier}

In Paragraaf 6.7 is in Figuur 38 de hoogtegroei van trilpopulier in de tabel van Misir et al. (2013) vergeleken met de nieuwe tabel voor Nederland. In Figuur 40 zijn die curven samen met de ontwikkeling van de hoogte van 8 proefperken met trilpopulier weergegeven.

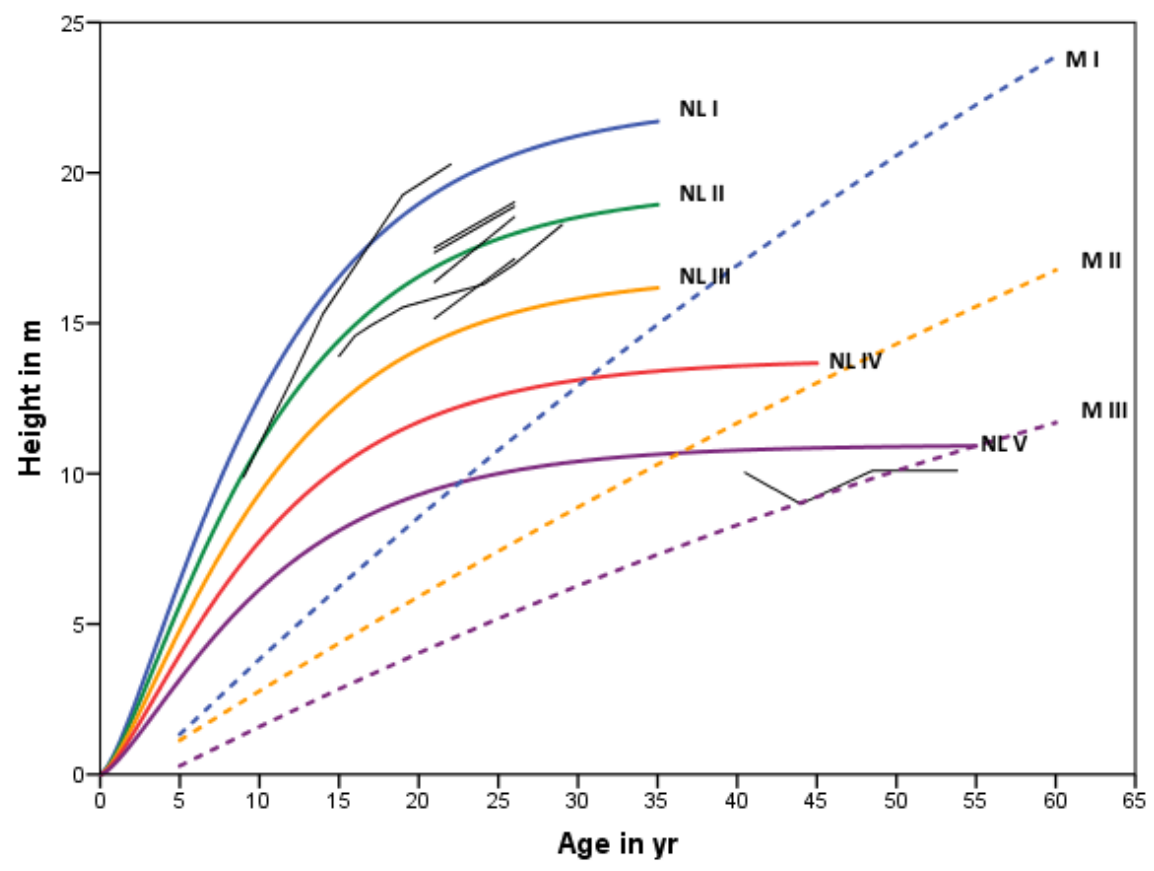

Figuur 41. Hoogteontwikkeling voor trilpopulier bij Misir et al. (M I - M II) en het nieuwe model voor Nederland (NL I - NL V) met de plots (zwarte lijnen).

Figure 41. Height development for aspen at Misir et al. (M I-M II) and those for the new model for Netherland (NL I-NL V) with de plots (black lines).

Te zien is dat bij ongeveer 55 jaar de hoogte van de $\mathrm{III}^{\mathrm{e}}$ boniteit van Misir et al. overeenkomt met die van de $\mathrm{V}^{\mathrm{e}}$ boniteit van de nieuwe tabel voor Nederland, evenzo voor de $\mathrm{I}^{\mathrm{e}}$ boniteit van beide tabellen.

Maar eigenlijk past het plot van ca $10 \mathrm{~m}$ hoog en 40 jaar en ouder niet alleen goed bij de $\mathrm{V}^{\mathrm{e}}$ boniteit van de nieuwe tabel voor Nederland maar ook bij de III ${ }^{\mathrm{e}}$ boniteit van de Turkse ta- 
bel. En indien er nog 2 betere boniteiten boven $\mathrm{l}^{\mathrm{e}}$ boniteit van de Turkse tabel geëxtrapoleerd worden dan is daar de hoogteontwikkeling van de overige plots goed mee te verklaren. De vorm van de curven in de nieuwe tabel leunt dus zwaar op de gezamenlijke afleiding met de overige populieren in Hoofdstuk 3 en volgt overduidelijk het patroon van een pionier soort. Maar volgens Von Wühlisch (2009) kan de soort 200 jaar en 40 m hoog worden en een diameter van meer dan een meter bereiken.

\subsection{Kwaliteit van het model}

Om de kwaliteit van het model te toetsen zijn de eerste $n-3$ opnamen van ieder proefperk modelmatig drie opnamen "doorgegroeid" waarbij dezelfde dunning van het stamtal als in werkelijkheid werd doorgevoerd (zie Tabel 27). De schattingen voor zowel de hoogte, diameter na dunning, het grondvlak na dunning als de grondvlakbijgroei van de laatste vervolgopname bleken onzuiver, en werden respectievelijk met $0.6 \%$ en $0.1 \%$ overschat, $0.1 \%$ onderschat en $2.8 \%$ overschat. Aangezien de afzonderlijke opnamen een ander gewicht in deze analyse hebben dan in de oplossing van de afzonderlijke regressiemodellen in de Hoofdstukken 3 en 4 kunnen hieraan geen consequentie worden verbonden. 


\section{Samenvatting}

Dit is een rapport over de groei en productie van de populier (Populus spec.) in Nederland. Er is onderzocht hoe de ontwikkeling van de hoogte, diameter en het grondvlak in de tijd is geweest en hoe deze beïnvloed wordt door de dunning en plantafstand. Met de gevonden relaties en andere allometrische relaties is een set opbrengsttabellen opgesteld voor diverse plantafstanden in bos, voor lijnbeplantingen en voor trilpopulier met een vaste dunninggraad.

De gebruikte dataset betreft de gegevens die sinds 1947 in Nederland in groei- en productieonderzoek bij de populier zijn verzameld door diverse bosbouwonderzoekgroepen die nu alle tot de WUR behoren. Het dunningonderzoek van Becking omvat 58 proefperken in bos en 32 in lijnbeplantingen, gemeten tussen 1947 en 2000. Daarnaast het groei- en productieonderzoek van de Dorschkamp/IBN, vermoedelijk gemeten tussen 1950 en 1995; dit omvat 76 proefperken met dunningonderzoek en 27 proefperken met plantafstandproeven. Daarnaast zijn 32 plots uit de $4^{\mathrm{e}}$ bosstatistiek, en later de HOSP, toegevoegd. In totaal betreft het 235 proefperken/plots met in totaal 1808 opnamen.

Per opname zijn leeftijd, hoogte en meestal ook de opnamedatum bekend en per toestand voor, na en van de dunning of sterfte stamtal, grondvlak, diameter, hoogte en volume. Van een groot aantal proefperken zijn ook de basisgegevens per boom bekend, inclusief de stamvoetcoördinaten. In deze studie is hiervan geen gebruik gemaakt.

De hoogteontwikkeling is onderzocht met zes groeimodellen en bleek het best te verklaren met het homomorfe model van Chapman-Richards (Pienaar \& Turnbull, 1973),

$h_{m}=h_{0}+f_{1}\left(s p_{0}\right) \cdot S \cdot\left(1-\exp \left(-c_{1} \cdot\left(t-t_{0}\right)\right)\right)^{f_{2}\left(c_{2}, s p_{0}\right)}$ voor $h_{m}>h_{0}$. Hierin is $S$ een proefperkspecifieke parameter en maat voor een absolute hoogteboniteit, $c_{1}$ en $c_{2}$ parameters die de vorm van de curve bepalen en verschillen per groep, $h_{0}$ en $t_{0}$ hoogte en leeftijd van de poot bij planten, $s p_{0}$ is de beginplantafstand. Met NLR en $R^{2}$ adj $=0.987$ werd een oplossing gevonden voor 3 groepen (trilpopulier, populier in bos en populier in lijnbeplanting). Voor $s p_{0}<3.3$ $\mathrm{m}$ werden de functies $f_{1}$ en $f_{2}$ actief. Voor $s p_{0} \geq 3.3 \mathrm{~m}$ geldt $f_{1}=1$ en $f_{2}=c_{2}$. Met 5 groepen variëteiten bleek $R^{2}$ adj zelfs 0.995 .

Naast het $R^{2}$ adj werden 5 andere criteria in de keuze meegewogen te weten Covariantie van de $S$-parameter, en het gemiddelde en intervallen voor de schattingen van $S, h_{\text {if }}$ (buigpunt) en $h_{25}$ (hoogte op 25 jaar) en de nauwkeurigheid van de schattingen van de overige parameters per model.

De diameterontwikkeling (voor dunning: $d_{b t}$ ) tot een hoogte van $7 \mathrm{~m}$ bleek een Gompertz model $d_{b t}=d_{7} \cdot\left\{\exp \left(-c_{9} \cdot e^{-c_{10} \cdot(h-1.30)}\right) / \exp \left(-c_{9} \cdot e^{-c_{10} \cdot(7-1.30)}\right)\right\}$ met $d_{7}=c_{6}+c_{7} \cdot s p_{0}$ voor $s p_{0}<c_{8}$. De diameter bij een hoogte van $7 \mathrm{~m}\left(d_{7}\right)$ voor en bleek een functie van het beginstamtal. Met een stamtal $N_{0}$ van 2500 bleek $d_{7} 9.1 \mathrm{~cm}$, bij stamtallen lager dan 686 is die $10.7 \mathrm{~cm}$. De $R^{2}$ adj bleek 0.961 . Het model is alleen gebruikt om de diameter- en grondvlakontwikkeling tot een hoogte van $7 \mathrm{~m}$ te voorspellen. Voor het traject boven een hoogte van $7 \mathrm{~m}$ is de grondvlakbijgroei gemodelleerd met het model van Jansen et al. (2016): $i_{G}=f\left(h, t, h_{25}, S \%\right)$ waarbij gebruik gemaakt is van een powermodel. Voor $S \%^{1}>29.2$ daalt de grondvlakbijgroei

\footnotetext{
${ }^{1}$ Hart-Becking Spacing Index of S\% van Hart.
} 
niet-lineair in S\% met 1.0 tot $2.3 \%$ per eenheid. De $R^{2}$ adj is 0.748 . In het oorspronkelijke model van Jansen et al. speelt ook het jaar van opname een rol omdat deze voor veel opnamen onbekend was kon dit niet worden onderzocht. Het model is in strijd met de wet van Eichhorn. Voor 2 situaties bleek het model niet te voldoen: voor lijnbeplantingen en voor dichte stand $\left(s p_{0} \leq 3 \mathrm{~m}\right)$. Voor dichte stand bleek $i_{d}=f\left(h, t, h_{25}, S \%\right)$ een beter model, na een zuiverheidscorrectie voor $i_{G}$ bedroeg $R^{2}$ adj 0.797. De grondvlakontwikkeling bij lijnbeplantingen bleken het best te voorspellen door de diameterontwikkeling te modelleren met $d_{b t}=D_{25} \cdot\left\{1-\exp \left(-a \cdot\left(t-t_{1.30}\right)\right) / 1-\exp \left(-a \cdot\left(25-t_{1.30}\right)\right)\right\}^{b}$ hierin is $D_{25}$ (de diameter voor dunning op 25 jarige leeftijd) een functie van $s p_{0}$ en $h_{25}$. De $R^{2}$ adj is 0.944 . Voor trilpopulier voldeed het model wel, maar aangezien er daar sprake is van laagdunning moest het effect van de dunning op de diameter na dunning $\left(d_{a t}\right)$ gemodelleerd worden met het La BastideFaber model (1972). Voor de standaard situatie wordt al dan niet systematisch gedund met ingreep van $50 \%$ zodra het $S \%$ onder $20.5 \%$ daalt. In de situatie zonder dunning vindt eindkap plaatst zodra het $S \%$ onder $17.5 \%$ daalt. Bij een dichte stand is sterfte met een $R^{2}$ adj van 0.690 als volgt gemodelleerd Mort $\%=f\left(s p_{0}, h_{25}, S \%\right)$. De uitkomst voldoet niet aan het model van Reineke (1933).

Met deze modellen is een opstand projectie model gemaakt om de werking van de integratie van de modellen voor hoogtegroei, grondvlakgroei en het effect van de dunning te toetsen. Het resultaat van deze test bleek redelijk. Met de geïntegreerde modellen zijn opbrengsttabellen gemaakt voor standaardsituaties voor leeftijden tot 40 à 50 jaar met 5 boniteiten en 5 plantafstanden. Deze zijn vergeleken met tabellen in Duitsland en het Verenigd Koninkrijk en met die van Faber \& Tiemens en die van Van Laar voor Nederland. Daarnaast zijn er korte omloop tabellen gemaakt met dichte stand en met sterfte waarbij er eindkap plaatsvindt, zodra er een maximale productie is bereikt, met 3 boniteiten en 3 plantafstanden. Daarnaast is een simulatie gemaakt van de opbrengsttabel bij een boomweide bosbehandeling volgens een Free Growth Model. De tabel met 5 boniteiten en een sterke laagdunning voor de trilpopulier is vergeleken met een Turks en een Zweeds model, van enige overeenkomst lijkt geen sprake,

Op hoofdlijnen bleek het model van Jansen et al. (2016) voor de douglas ook bruikbaar voor populier, voor de hoogtegroei bleek het model van Chapman-Richards beter. 


\section{Summary}

This report presents the results of a study on growth and yield of poplar (Populus spec.) in the Netherlands. The development over time of height, diameter and basal area is examined, combined with the effects of thinning and initial spacing. The relationships found, and additional allometric relationships were used to construct a set of yield tables for plantations with different spacing, for line plantations, and for aspen stands with a fixed thinning grade.

The dataset used in this study includes results of research carried out since 1947 by various forestry research groups, now all part of Wageningen University and Research Centre. The largest data collection concerns the growth and yield research at the former Dorschkamp/IBN institute with 76 experimental thinning plots and 27 experimental spacing trials, measured between 1950 and 1995. In addition a thinning trial initiated by Becking, including 58 experimental plots in forest and 32 plots in line plantations, measured between 1947 and 2000, is included. Moreover, 32 plots from the $4^{\text {th }}$ Dutch National Forest Inventory, and later on the timber prognosis system HOSP, were used as control plots. In total, data from 235 plots with 1808 recordings are available.

For each plot record, age, average height and often also the recording date are known, as well as stem density, basal area, diameter, height and volume before, and after thinning, and of the thinning itself. For the plots without thinning, data are available before mortality, after mortality and of the mortality itself. In many plots also the individual tree characteristics within the plots are known, including the stem coordinates, but these were not used in this study.

The height development was studied using six well-known growth models and the best fit was found with the model of Chapman-Richards:

$h_{m}=h_{0}+f_{1}\left(s p_{0}\right) \cdot S \cdot\left(1-\exp \left(-c_{1} \cdot\left(t-t_{0}\right)\right)\right)^{f_{2}\left(c_{2}, s p_{0}\right)}$ for $h_{m}>h_{0}$.

Here, $S$ is a plot specific parameter and a measure for site index; $c_{1}$ and $c_{2}$ are group specific parameters determining the shape of the curve for three groups (poplar, aspen and line plantations); $h_{0}$ and $t_{0}$ represent height and age of the cuttings at planting time, $s p_{0}$ is the initial spacing. The model gives a polymorphic system of height development curves. The solution with nonlinear regression and $R^{2}$ adj $=0.987$ yields separate values for the three groups (aspen, poplar in forest and poplar in line plantations). For $s p_{0}<3.3 \mathrm{~m}$ the functions $f_{1}$ and $f_{2}$ become active: for $s p_{0} \geq 3.3 \mathrm{~m}, f_{1}=1$ and $f_{2}=c_{2}$. With five groups of varieties an $R^{2}$ adj of 0.995 was obtained.

In addition to $R^{2}$ adj, other criteria were used in model selection: covariance of the $S$ parameter, the inflection point $h_{i f}, h_{25}$ and the accuracy of the other estimated parameters for all the examined models.

To describe the diameter development (before thinning: $d_{b t}$ ) up to a tree height of $7 \mathrm{~m}$ the model of Jansen et al. (2016) was used. This model contains a Gompertz function:

$d_{b t}=d_{7} \cdot\left\{\exp \left(-c_{9} \cdot e^{-c_{10} \cdot(h-1.30)}\right) / \exp \left(-c_{9} \cdot e^{-c_{10} \cdot(7-1.30)}\right)\right\}$ where $d_{7}=c_{6}+c_{7} \cdot s p_{0}$ for $s p_{0}<c_{8}$. With an initial stem density of $N_{0}=2500$, the diameter at height $=7 \mathrm{~m}\left(d_{7}\right)$ is $9.1 \mathrm{~cm}$, and with $N_{0}<$ $686, d_{7}=10.7 \mathrm{~cm} . R^{2}$ adj for the model was 0.961 . The model was only used for the basal area growth trajectory towards a tree height of $7 \mathrm{~m}$, since no thinning took place. Above a 
height of $7 \mathrm{~m}$, basal area increment was modelled using the model by Jansen et al. (2016) $i_{G}=f\left(h, t, h_{25}, S \%\right)$ using a power function. For $S \%^{1}>29.2$, the basal area increment decreased non-linear in $S \%$ with 1.0 to $2.3 \%$ per unit. $R^{2}$ adj of the model was 0.748 . In the original model by Jansen et al. (2016) the year of recording was also a model factor, but this variable could not be examined because it was not known for a number of plots. The model conflicts with Eichorn's law. For two specific situations (line plantations and dense spacing with $\left.s p_{0} \leq 3 \mathrm{~m}\right)$ other models has a better fit. For $s p_{0} \leq 3 \mathrm{~m}, i_{d}=f\left(h, t, h_{25}, S \%\right)$ gave a better description; after a bias correction for $i_{G}$, an $R^{2}$ adj of 0.797 was found.

For line plantations, basal area development was best predicted by using a model for the diameter development $d_{b t}=D_{25} \cdot\left\{1-\exp \left(-a \cdot\left(t-t_{1.30}\right)\right) / 1-\exp \left(-a \cdot\left(25-t_{1.30}\right)\right)\right\}^{b}$ in which $D_{25}$ is a function of $s p_{0}$ and $h_{25}$, with $R^{2}$ adj of 0.944 . For aspen, the model fits but because thinning from below was used here also the effect from thinning on the diameter after thinning was modelled using the model from La Bastide \& Faber (1972).

In standard situations with thinning, a systematic thinning of $50 \%$ was modelled as soon as the $S \%$ falls below $20.5 \%$. In a standard situation without thinning, final harvest was modelled as soon as the $S \%$ falls below $17.5 \%$. For dense spacing, mortality was modelled with Mort $\%=f\left(s p_{0}, h_{25}, S \%\right)$. The resulting model had an $R^{2}$ adj of 0.690 , but the result is in conflict with Reineke's law (1933).

A stand projection model was made using the models described, to test the integration of the sub models for height development, basal area growth and thinning. The results are in reasonable agreement with measured data. The integrated model was used to develop yield tables for standard situations to an age of 40 to 50 year for two geographical regions, for five site classes and five spacing classes. These tables were compared to yield tables from Germany and the United Kingdom, and with those of Faber \& Tiemens (1975) and Van Laar (1957) for the Netherlands. Besides these tables, additional tables were developed for short rotation stands with dense spacing, and a final cut at the time of maximal mean annual volume increment, for three site classes and three different spacings. In addition, a simulation for a Free Growth Model was made. The aspen yield table with five site classes and heavy thinning from below was compared to a Turkish and a Swedish model, showing large differences.

In general, the model from Jansen et al. (2016) for Douglas fir appears suitable for poplar, but for the height development the model of Chapman-Richards gives a better fit.

\footnotetext{
${ }^{1}$ Hart-Becking Spacing Index or S\% from Hart.
} 


\section{Literatuur}

Bartelink, H.H., A.F.M. Olsthoorn, A. Oosterbaan \& S.M.J. Wijdeven, 2001. Overzicht van een eeuw onderzoek naar groei en opstandsontwikkeling in relatie tot groeiplaats en beheer. Alterra, Research Instituut voor de Groene Ruimte, Wageningen, Alterrarapport 256.

Bartelink, H.H., J.J. Jansen, L.G. Goudzwaard, H. Lu, J.F. Oldenburger, A. Oosterbaan, G.M. Mohren and J. den Ouden. 2016. FEM growth and yield data Mixed species forest. Dans DOI: http://dx.doi.org/10.17026/dans-z5m-kp67.

Becking, J.H. \& P.G. de Vries, 1959. Richtlijnen voor de bedrijfsregeling van bosbezit in Nederland . Commissie bosbdrijfsregeling van Nederland. $56 \mathrm{p}$.

Burkhart, H,E. \& R.B. Tennent, 1977. Site index equations for radiata pine in New Zealand. New Zealand Journal of Forestry Science 7: 408416.

C.B.S. (Centraal Bureau voor de Statistiek), 1985. De Nederlandse Bosstatistiek, deel 1: de oppervlakte bos, 1980 1983. Staatsuitgeverij, s'Gravenhage.

C.B.S. (Centraal Bureau voor de Statistiek), 1989. De Nederlandse bosstatistiek, deel 2: landschappelijke beplantingen 1983 - 1984. Staatsuitgeverij, s'Gravenhage.

Crocoll, A., 1954. Der Massenertrag von Pappelbeständen in die nordbadischen Rheinebene, 8. Beiheft zum Forstwiss. Centralblad.

Cieszewski C.J., 2001. Three methods of deriving advanced dynamic site equations demonstrated on inland Douglas-fir site curves. Can. J. For. Res. 31: 165-173.

Den Ouden, J., G.M.J. Mohren and J.J. Jansen, 2016. FEM growth and yield data - Poplar roadside plantations (revised version). DANS DOI: https://doi.org/10.17026/dans-xkyzh99.

De Vries, P. G., 1962. Een onderzoek naar de invloed van de boomafstand op de massaproduktie en op de vorm van de stamdoorsnede bij eenrijige populierenbeplantingen. Nederlands Bosbouwtijdschrift 34, 238-248.

Dirkse, G.M., W.P. Daamen, H. Schoonderwoerd, M. Japink, M. van Jole, R. van Moorsel, P. Schnitger, W.J. Stouthamer, M. Vocks, 2007. Meetnet Functievervulling bos 20012005, Vijfde Nederlandse Bosstatistiek. Directie Kennis, Ministerie van Landbouw, Natuur en Voedselkwaliteit, Rapport DK nr. 2007/065, Ede. 95 pp. (en de daarbij behorende database "NBI-2012-MFV-2006.mdb")

Faber, P.J. \& F. Tiemens, 1975. De opbrengstniveaus van populier Uitvoerig verslag Rijksinstituut voor onderzoek in de bos en landschapsbouw "De Dorschkamp" Band 13(1), Wageningen.

Faber, P.J., 1985. Groei en plantafstand van 'Rap' populier in een Nelderproef. Nederlands Boschbouwtijdschrift 24: 157-166.

Gehrhardt, E., 1909. Über Bestandeswachstumsgesetze und ihre Anwendung zur Aufstellung von Ertragstafeln. Allg. Forst- u. J.-Ztg. 85: 117-128.

Gompertz, B. 1832. "On the Nature of the Function Expressive of the Law of Human Mortality, and on a New Mode of Determining the Value of Life Contingencies." Phil. Trans. Roy. Soc. London 123, 513-585

Hamilton, G.J. and J.M. Christie, 1971. Forest management tables (metric). Forestry Commission Booklet no. 34. HMSO, London.

Hart, H.M.J., 1928. Stamtal en dunning : een orienteerend onderzoek naar de beste plantwijdte en dunningswijze voor den djati. Proefschrift Wageningen. Mededeelingen Proefstation voor het Boschwezen (21) 219 p. + 7 bijl. Veenman, Wageningen. 
Heisterkamp, S.H., 1981. Opstandsinhoudsfuncties. Rapport Rijksinstituut voor onderzoek in de bos- en landschapsbouw "De Dorschkamp" 271, Wageningen.

Houtzagers, M.R. en Schmidt, P. De reactie van populierenklonen op concurrentie in relatie tot groeiruimte. 1994. Department of Forestry, Agricultural University Wageningen, Hinkeloord Reports 12, ISSN 0928-1797

Jansen, J.J., 1990. Diameterbijgroei en boomafstand bij lijnvormige beplantingen van populier. In: P. Schmidt (red.), De Populier - Verslag Studiekring 1990 Koninklijke Nederlandse Bosbouw Vereniging, Nederlands Bosbouwtijdschrift 62: 231-235.

Jansen, J.J., H. Schoonderwoerd, G.M.J. Mohren and J. den Ouden, 2016. Groei en productie van douglas in Nederland. Becking's dunningproeven ontsloten. Wageningen Academic Publishers. DOI: http://dx.doi.org/10.3920/978-90-8686-827-8

Jansen, J.J., J. Sevenster \& P.G. Faber (ed.), 1996. Opbrengsttabellen voor belangrijke boomsoorten in Nederland. IBN rapport 96/Hinkeloord reports No.17, Wageningen Universiy, Wageningen.

Jansen, J.J., A. Oosterbaan, G.M.J. Mohren \& J. den Ouden, 2018a. Groei en productie van Japanse lariks in Nederland. FEM Groei en productie rapport 2018-1, Wageningen Universiy.

Jansen, J.J., G.M.J. Mohren, A. Oosterbaan \& J. den Ouden, 2018b. Groei en productie van fijnspar in Nederland. FEM Groei en productie rapport 2018 - 2, Wageningen Universiy.

Jansen, J.J., G.M.J. Mohren, A. Oosterbaan , L. Goudzwaard en J. den Ouden, 2018c. Groei en productie van grove den in Nederland. FEM Groei en productie rapport 2018 -3, Wageningen Universiy.

Jansen, J.J., A. Oosterbaan, G.M.J. Mohren \& J. den Ouden, 2018d. Groei en productie van zomereik in Nederland. FEM Groei en productie rapport 2018-4, Wageningen Universiy.

Jansen, J.J., G.M.J. Mohren, A. Oosterbaan , L. Goudzwaard en J. den Ouden, 2018e. Groei en productie van beuk in Nederland. FEM Groei en productie rapport 2018 - 5, Wageningen Universiy.

Johansson, T., 1996. Site index curves for European aspen (Populus tremula L.) growing on forest land of different soils in Sweden. Silva Fennica, 30(4), 437-458

Johansson, T, 2011. Site index curves for poplar growing on former farmland in Sweden, Scandinavian Journal of Forest Research, 26:2, 161-170.

Karacic, A., T. Verwijst, and M. Weih, 2003. Above-ground woody biomass production of short-rotation populus plantations on agricultural land in Sweden. Scand. J. For. Res. 18: 427/437, 2003.

Korf, V. (1939): Příspevěk k matematické formulaci vzrůstového zákona lesních porostů. [Contribution to mathematical definition of the law of stand volume growth.] Lesnická práce, 18: 339-379.

La Bastide, J.G.A. \& P.J. Faber, 1972. Revised yield tables of six tree species in the Netherlands. Uitvoerig verslag Stichting bosbouwproefstation "De Dorschkamp" Band 11(1), Wageningen.

Misir, M., N. Misir, Ş. Bayburtlu and F. Bilgili, 2013. The yield of natural trembling aspen (Populus tremula I.) stands (Northern and Eastern Anatolia). Pak. J. Agri. Sci., Vol. 50(4), 537-547. 
Mohren, G.M.J., L.G. Goudzwaard, J.J. Jansen, A. Oosterbaan, J.F. Oldenburger, \& J. den Ouden (revised version), 2017. FEM growth and yield data Monocultures - Poplar. Dans DOI: https://doi.org/10.17026/dans-zu3-256e

Nelder, J.A. 1962. New kinds of systematic designs for spacing experiment. Biometrics 18, 283-307

Pienaar, L.V., \& K.J. Turnbull, 1973. The Chapman-Richards generalization of von Bertallanffy's growth model for basal area growth and yield in even-aged stands. Forest Science 19: 2-22.

Rätzel, K., 1969. Die Ertragsleistung der Robusta-Pappel im geschlossenen Bestand, Allgem. Forst- u. Jagdzeitg. S. 239-250

Reineke, L.H., 1933. Perfecting a stand density index for even-aged forests. Jour. Agric. Res. 46, 627-638.

Schober, R., 1987. Ertragstafeln wichtiger Baumarten bei verschiedener Durchforstung. Dritte neubearb. Aufl. Sauerländer, Frankfurt a. M.

Schoonderwoerd, H., J.J. Jansen, G.M.J. Mohren, A. Oosterbaan, J.F. Oldenburger, L. Goudzwaard and J. den Ouden, 2016. FEM growth and yield data Monocultures Douglas fir. Dans DOI: http://dx.doi.org/10.17026/dans-x9t-rxd7.

Schnute, J., 1981. A versatile growth model with statistically stable parameters. Canadian Journal of Fisheries and Aquatic Sciences 38: 1128-1140.

Schumacher, F.X. and F.S. Hall, 1933. Logarithmic expression of timber-tree volume. Journal of Agricultural Research, v.47, n.9, p.719-734

Van Laar, A., 1957. Opbrengsttabel Populier. In: J.H. Becking, \& P.G. de Vries, 1959. Richtlijnen voor de bedrijfsregeling van bosbezit in Nederland . Commissie bosbdrijfsregeling van Nederland. $56 \mathrm{p}$.

Von Wühlisch, G. 2009. EUFORGEN Technical Guidelines for genetic conservation and use of Eurasian aspen (Populus tremula) Bioversity International, Rome, Italy. 6 pages. 


\section{Bijlage 1. Opbrengsttabellen voor populier}

\section{Toelichting opbrengsttabellen}

In de kop van de opbrengsttabellen zijn een aantal standaard symbolen (IUFRO, 1959) en daarvan afgeleide varianten gebruikt, in onderstaande tabel wordt de SI-eenheid vermeld en de betekenis van het symbool weergegeven. Voor definities van deze begrippen en een nadere toelichting erop zie in voorafgaande tekst.

\begin{tabular}{|c|c|c|}
\hline symbool & eenheid & betekenis \\
\hline Boniteit & & relatieve indeling in groeiklassen \\
\hline h25 & $\mathrm{m}$ & site index (gemiddelde hoogte op 25 jr) \\
\hline P25 & $m^{3} h a^{-1} j^{-1}$ & productieklasse op $25 \mathrm{jr}^{1)}$ \\
\hline MMAI & $m^{3} h a^{-1} j^{-1}$ & maximale gemiddelde jaarlijkse bijgroei \\
\hline$t$ & j & leeftijd vanaf stek \\
\hline$h_{m}$ & $\mathrm{~m}$ & gemiddelde hoogte \\
\hline$h_{\text {top }}$ & $\mathrm{m}$ & opperhoogte ${ }^{2)}$ \\
\hline$d_{d o m}$ & $\mathrm{~cm}$ & gemiddelde diameter van dominante hoogte boom \\
\hline$N$ & $h a^{-1}$ & stamtal per ha \\
\hline$S \%$ & & S\% (Hart-Becking spacing index) \\
\hline G & $m^{2} h a^{-1}$ & grondvlak per ha \\
\hline$d_{g}$ & $\mathrm{~cm}$ & diameter $(1,30 \mathrm{~m})$ van de grondvlakmiddenboom ${ }^{3)}$ \\
\hline dor & $\mathrm{cm}$ & diameter loodrecht op rij ${ }^{4}$ \\
\hline dir & $\mathrm{cm}$ & diameter in de rij ${ }^{4)}$ \\
\hline$h_{g}$ & $\mathrm{~m}$ & hoogte middenboom 2) \\
\hline$V$ & $m^{3} h a^{-1}$ & volume per ha ${ }^{4)}$ \\
\hline$I c_{G}$ & $m^{3} h^{-1}$ & lopende grondvlakbijgroei per ha op leeftijd $t$ jaar \\
\hline$I c_{V}$ & $m^{2} h a^{-1} j^{-1}$ & lopende volumebijgroei oer ha op leeftijd $t$ jaar \\
\hline$I m_{G}$ & $m^{3} h^{-1} j^{-1}$ & gemiddelde grondvlakbijgroei per ha tot op leeftijd $t$ jaar \\
\hline $\operatorname{lm} V$ & $m^{3} h a^{-1} j^{-1}$ & gemiddelde volumebijgroei per ha tot op leeftijd $t$ jaar \\
\hline
\end{tabular}

1) gemiddelde productie, inclusief dunning maar exclusief sterfte (volumebijgroei) per ha tot op leeftijd 25 jaar

2) alleen bij trilpopulier

3) boom met gemiddeld boomgrondvlak en boomvolume

4) bij lijnbeplantingen

5) het volume is gedefinieerd als het spilhoutvolume met schors.

NB bij lijnbeplanting geldt voor stamtal, grondvlak, volume en bijgroei per km i.p.v. per ha 


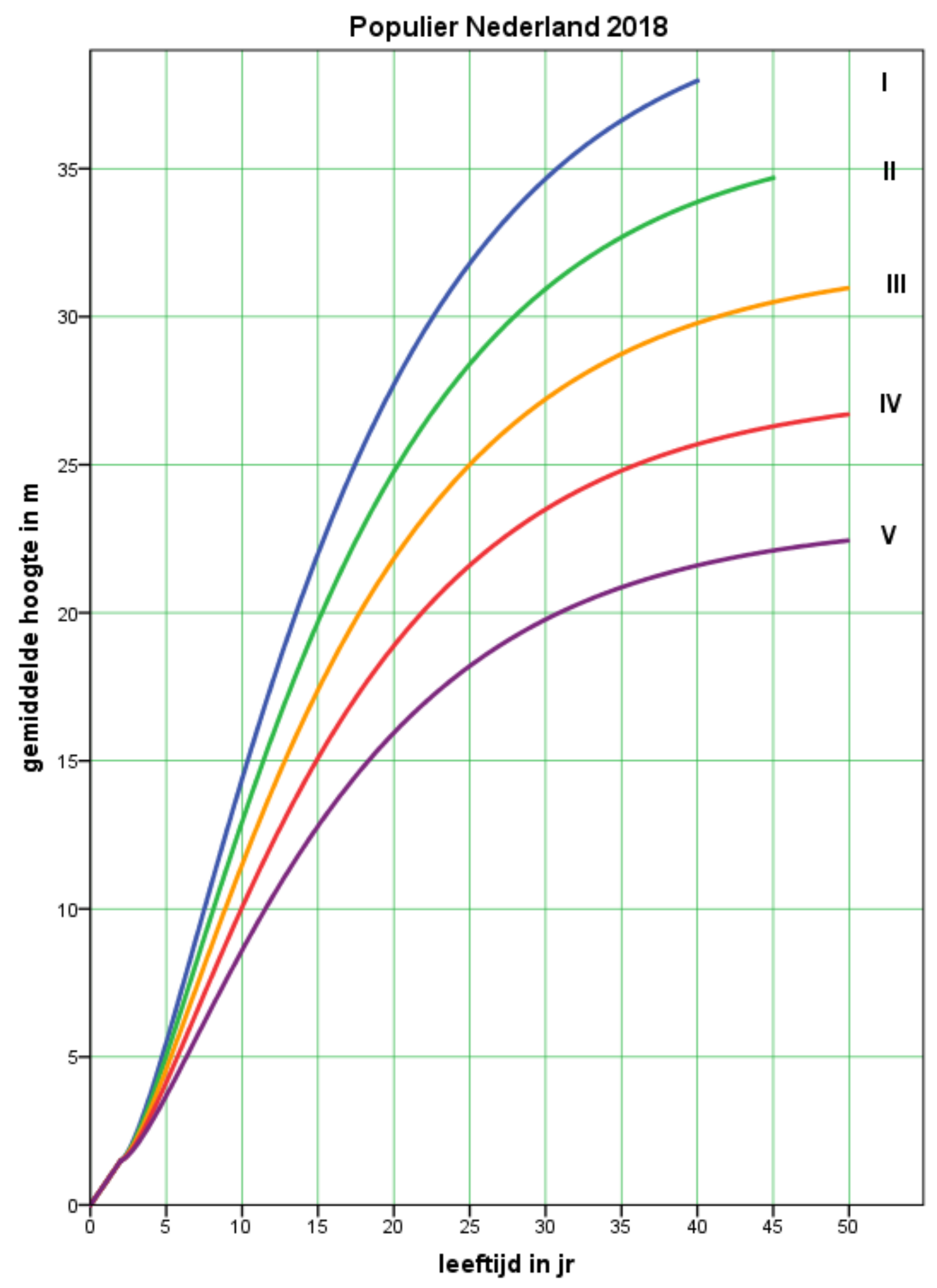




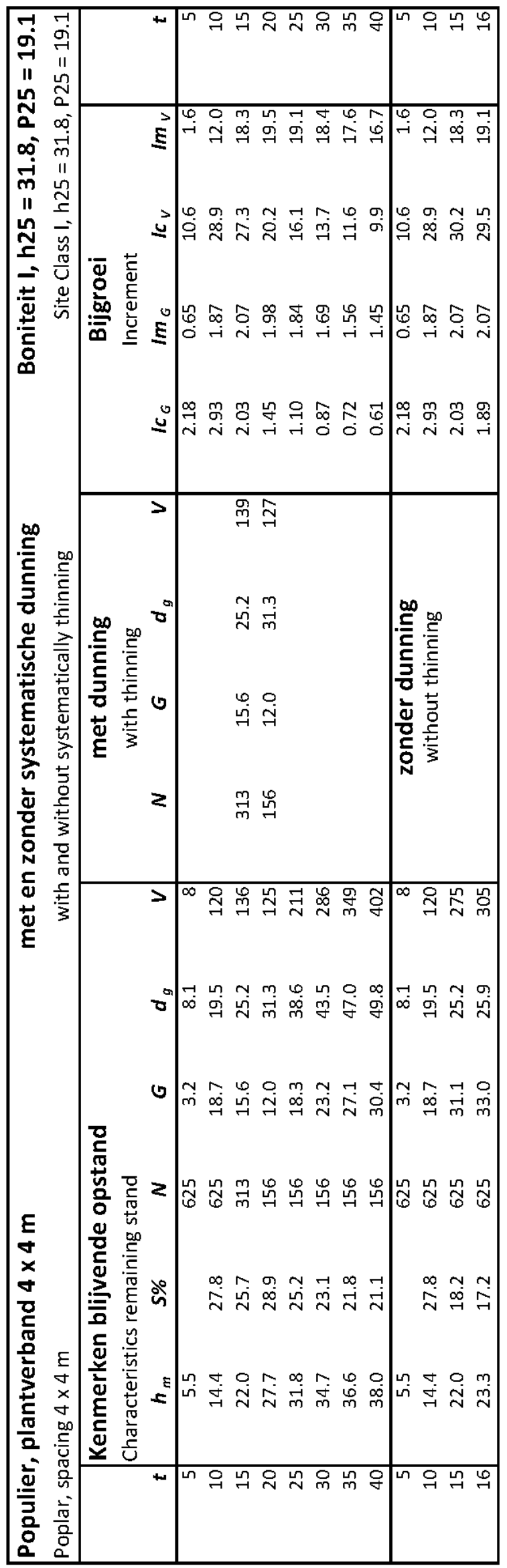




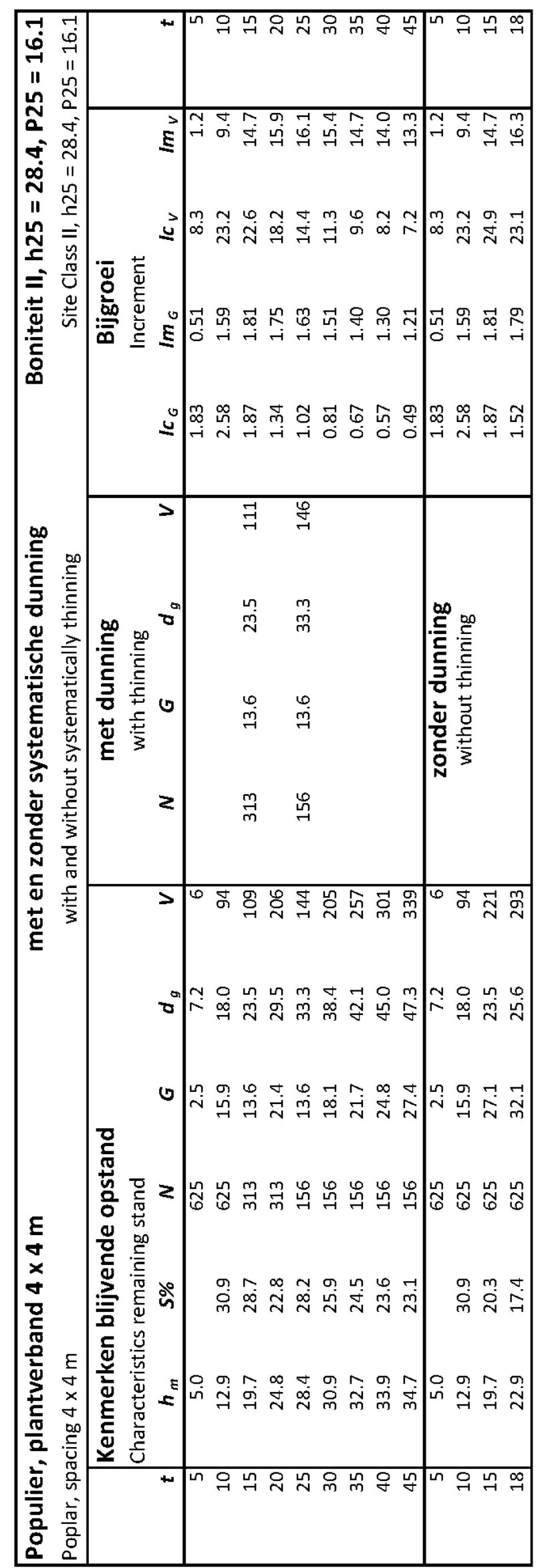




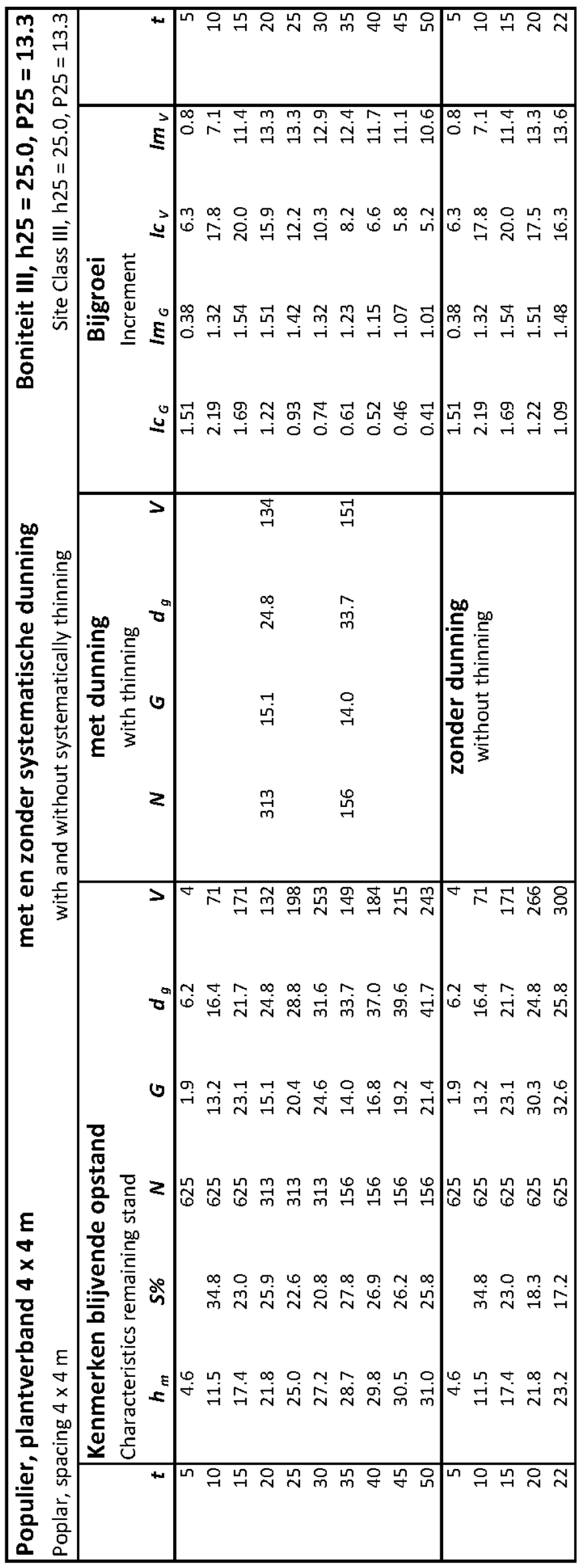




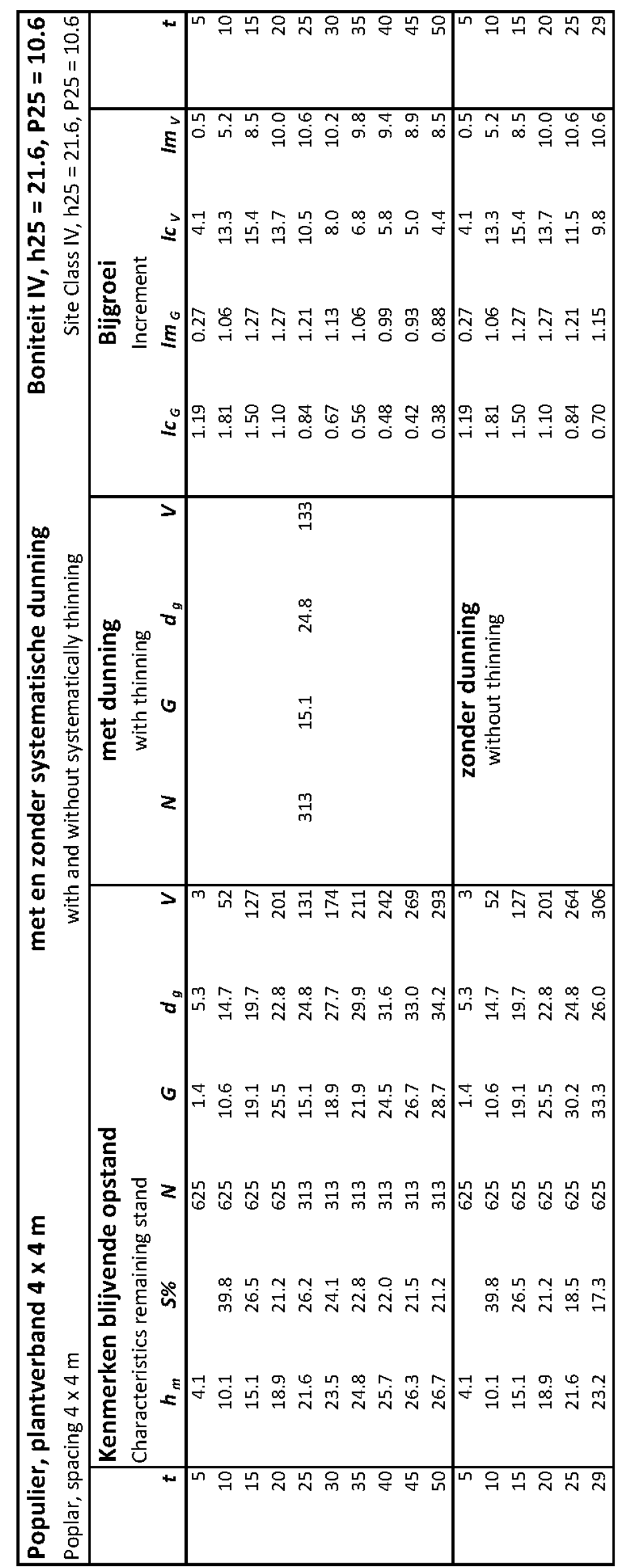




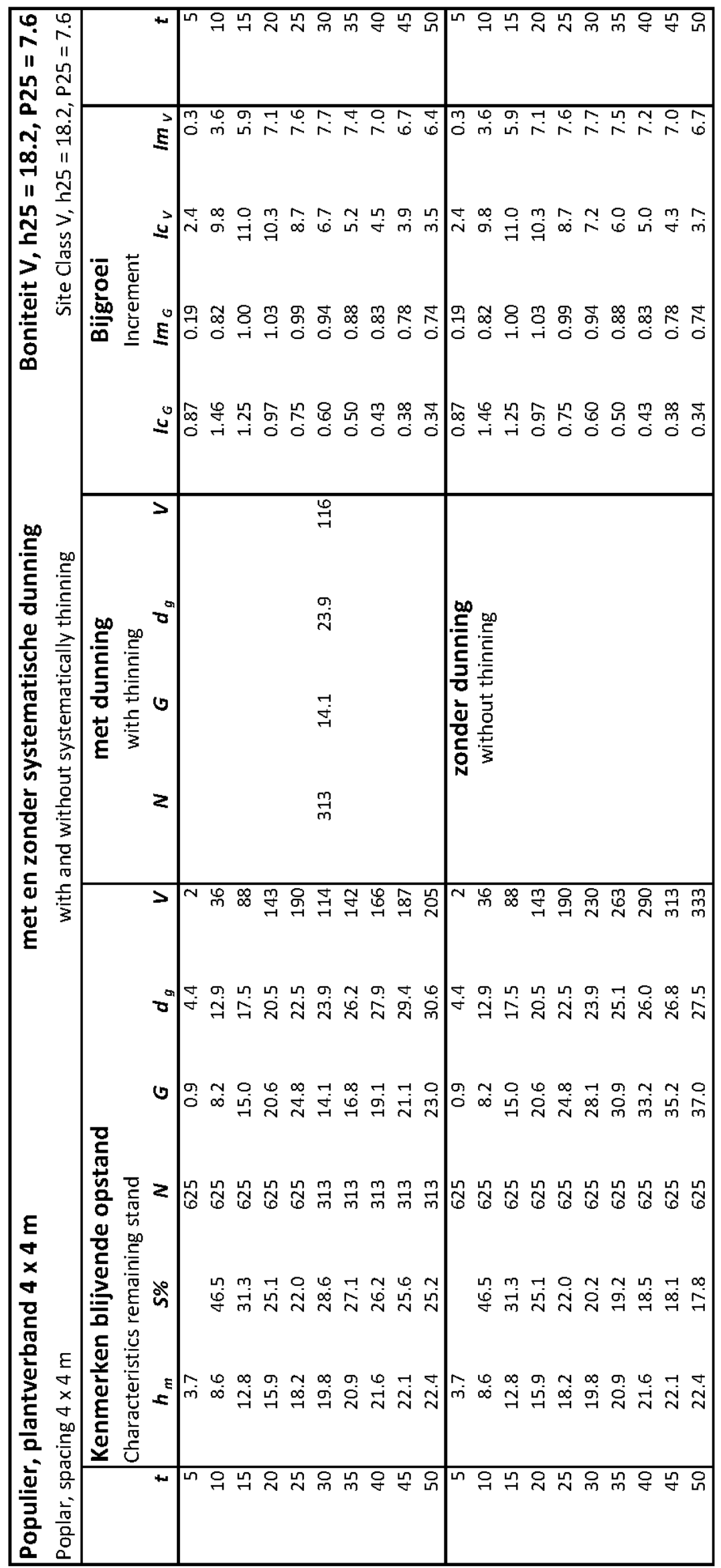




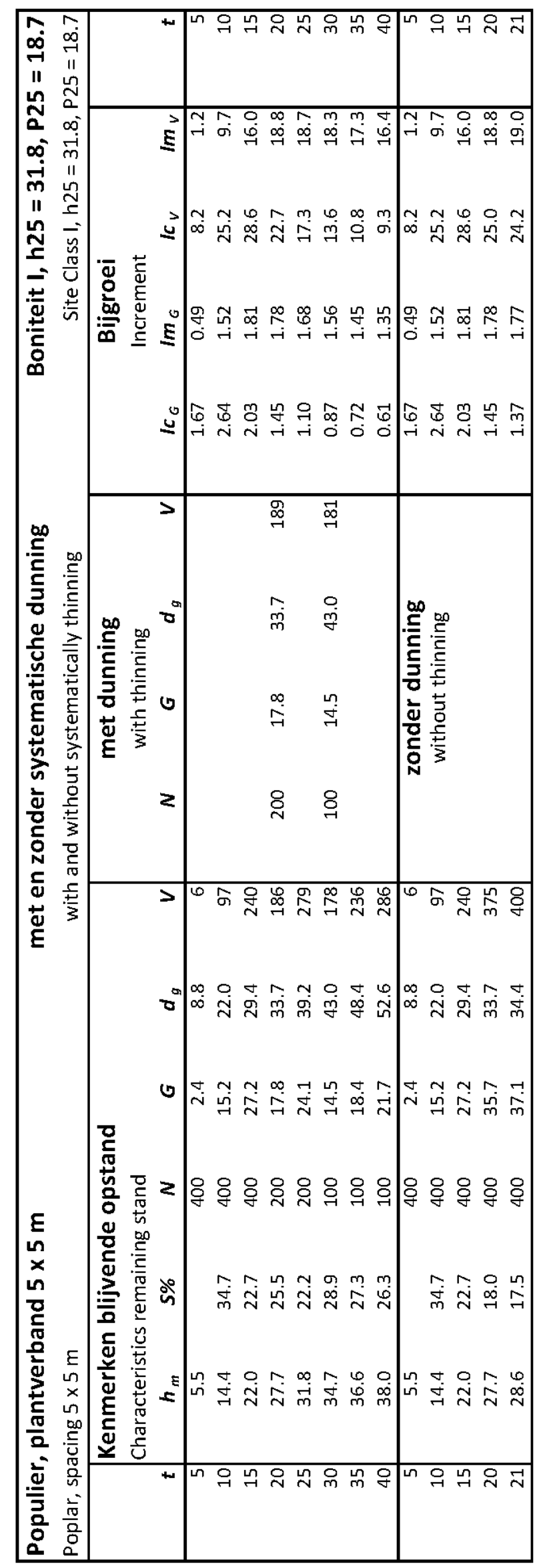




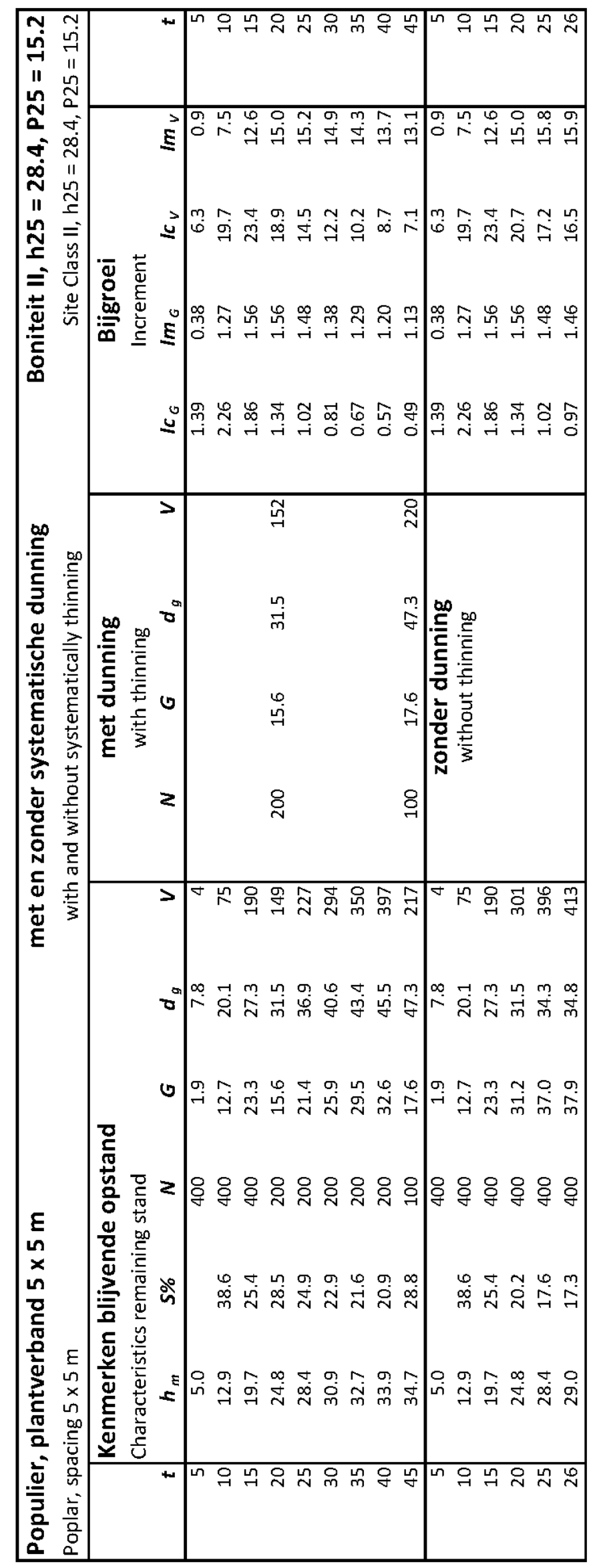




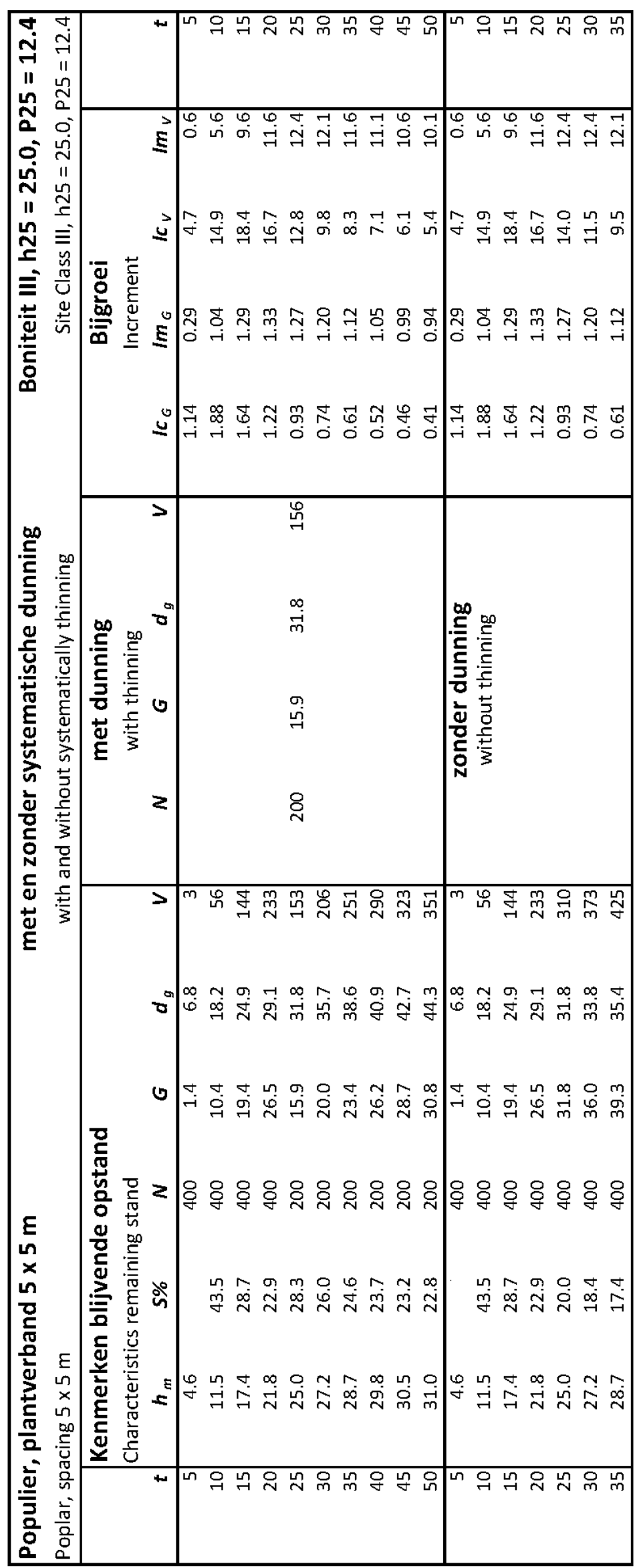




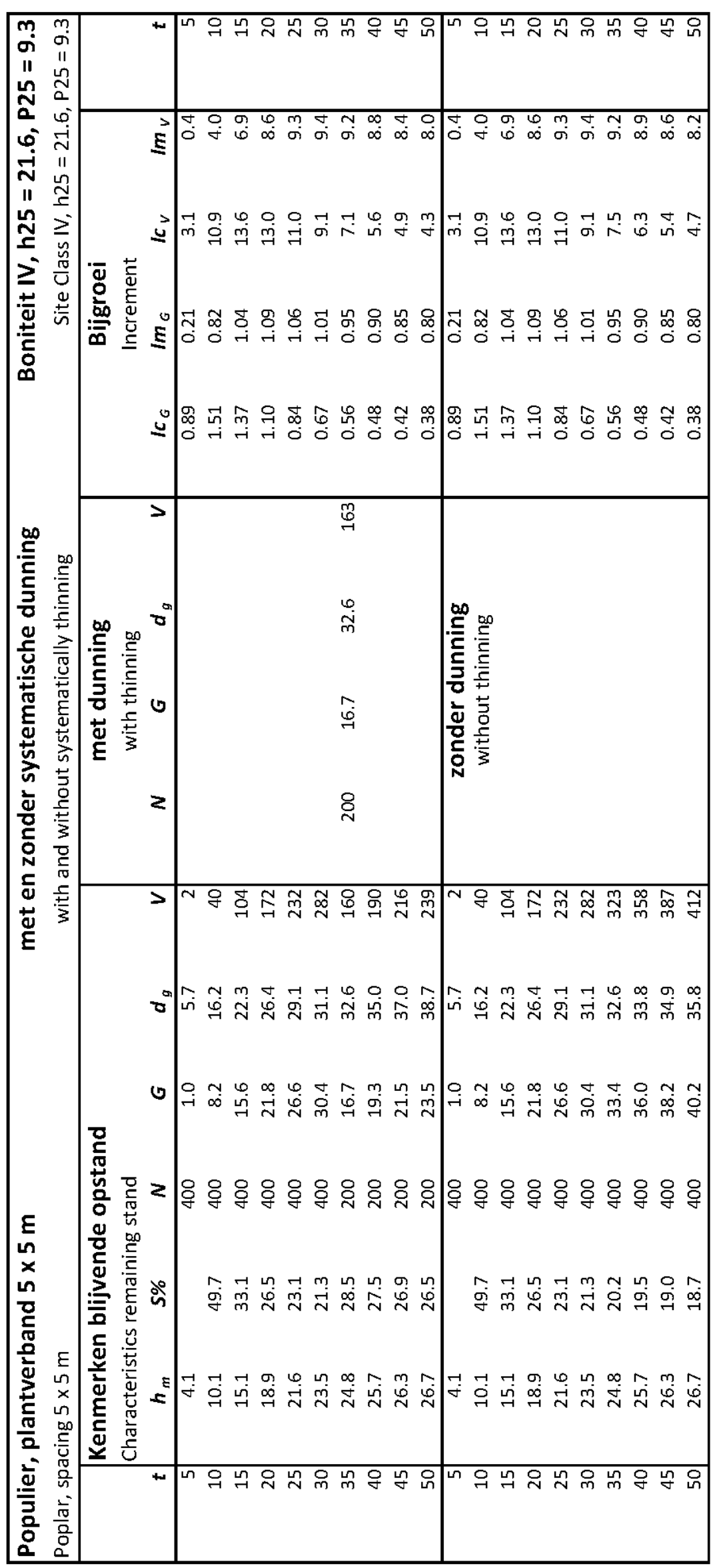




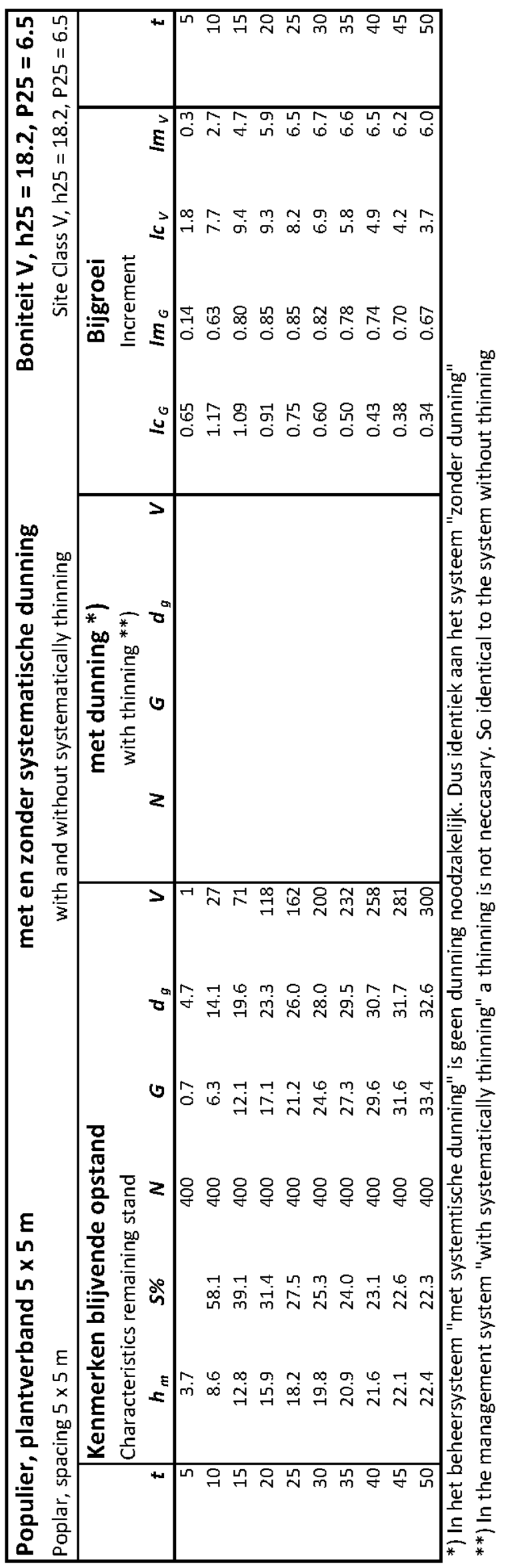




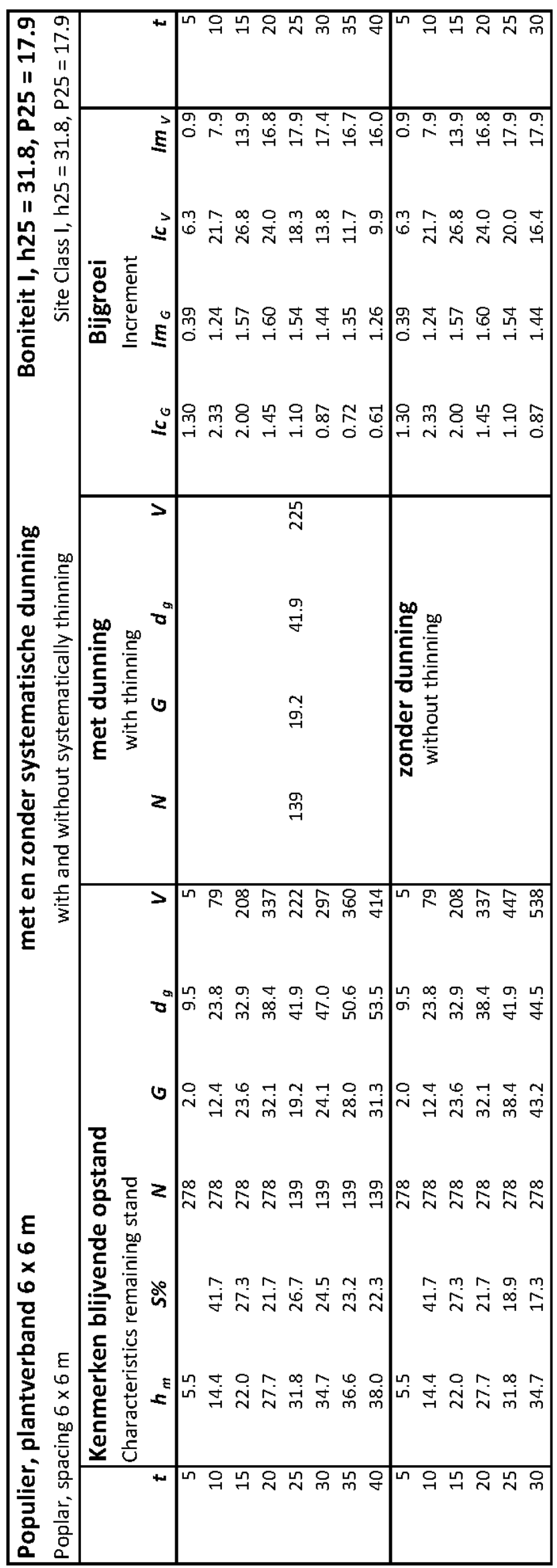




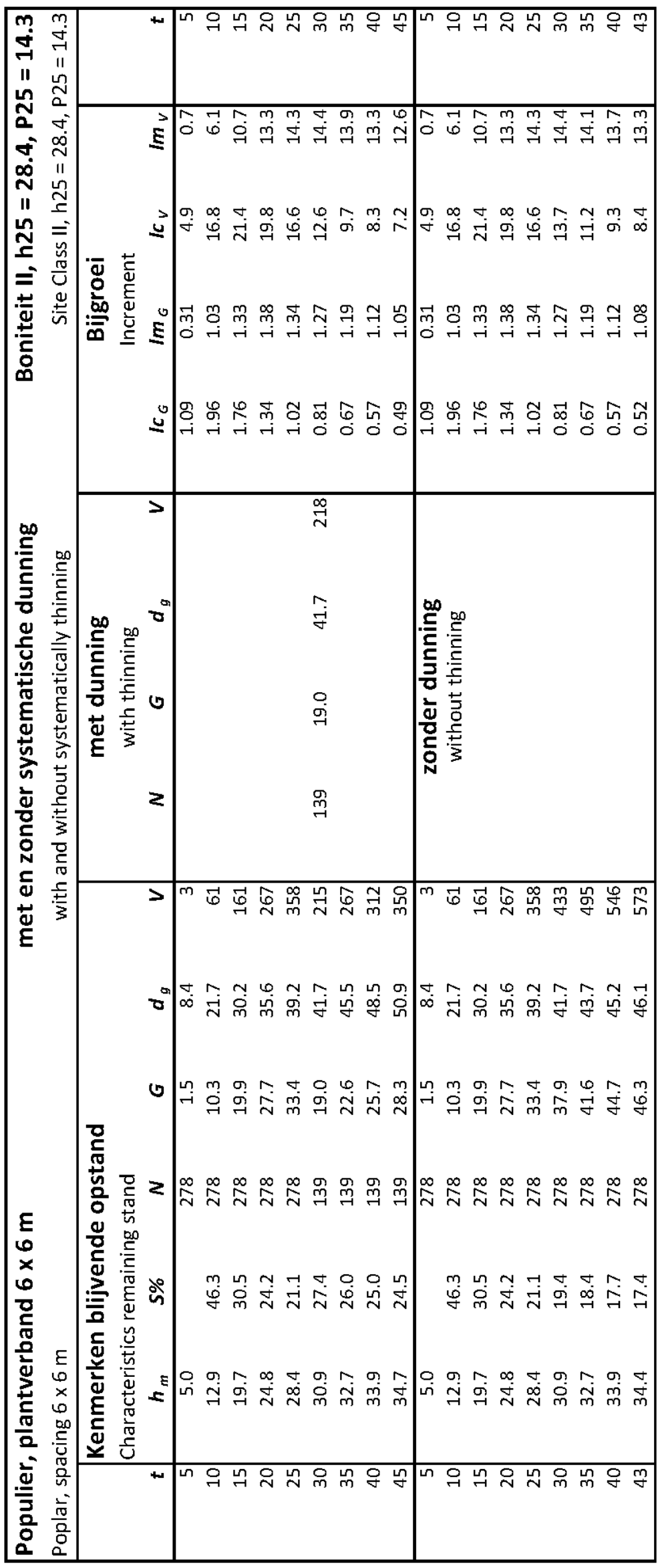




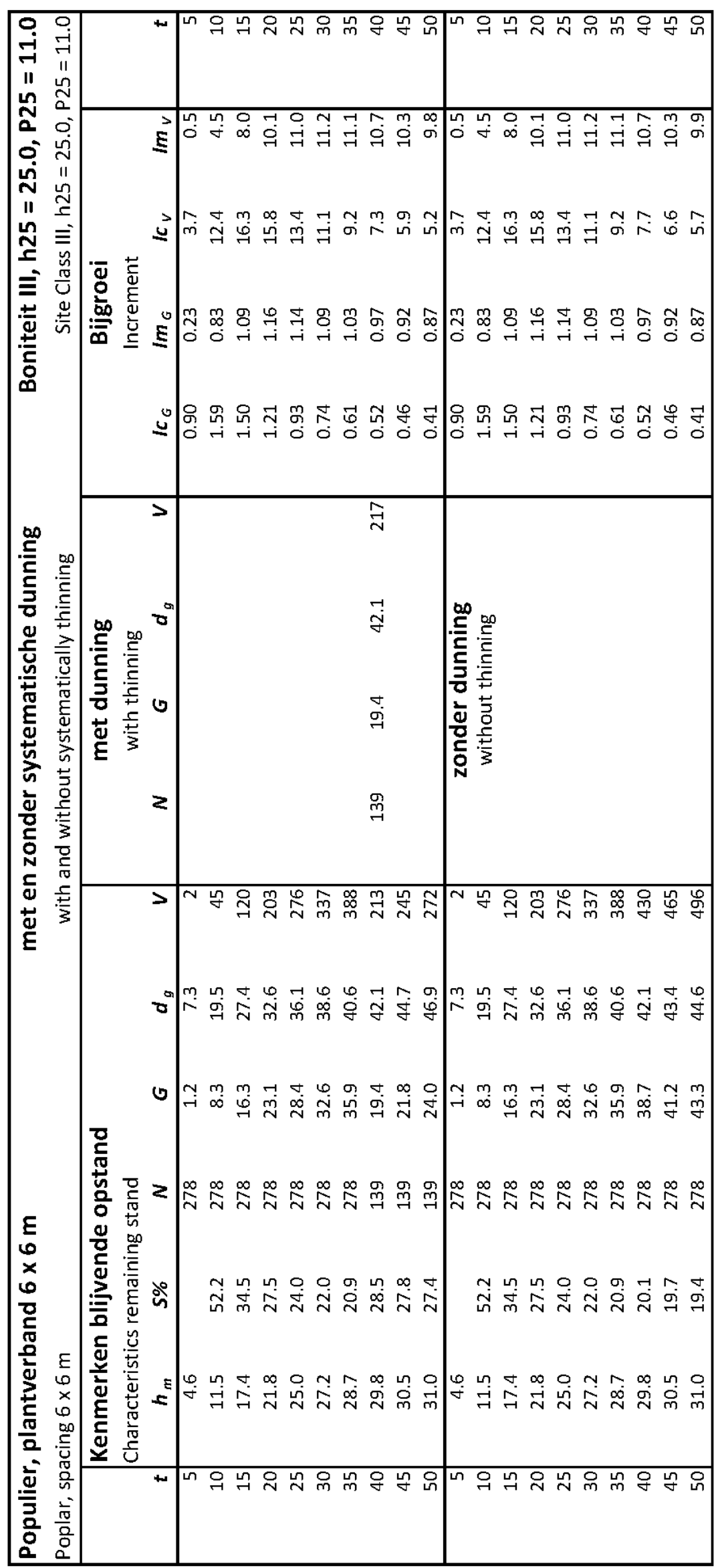



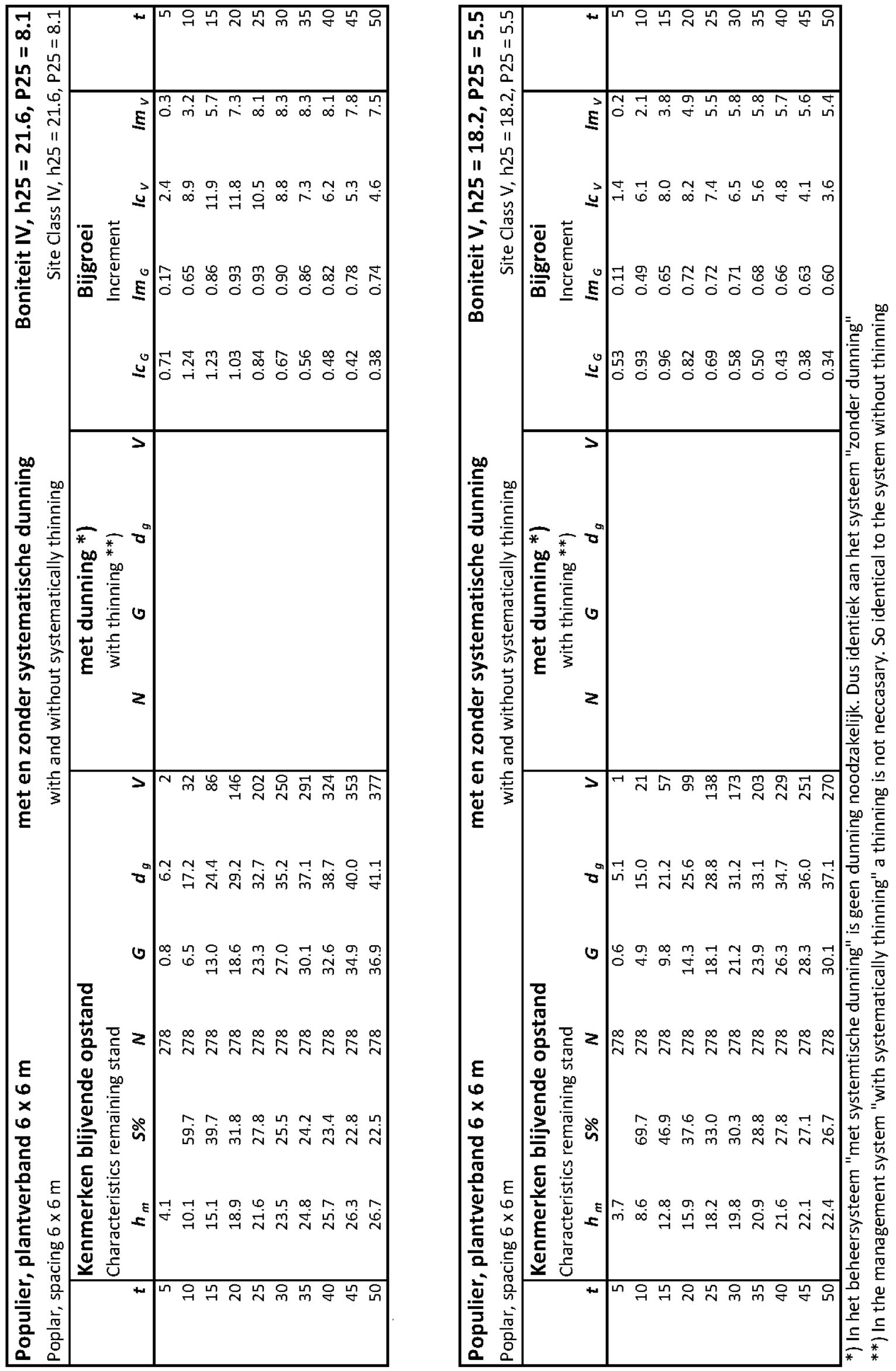

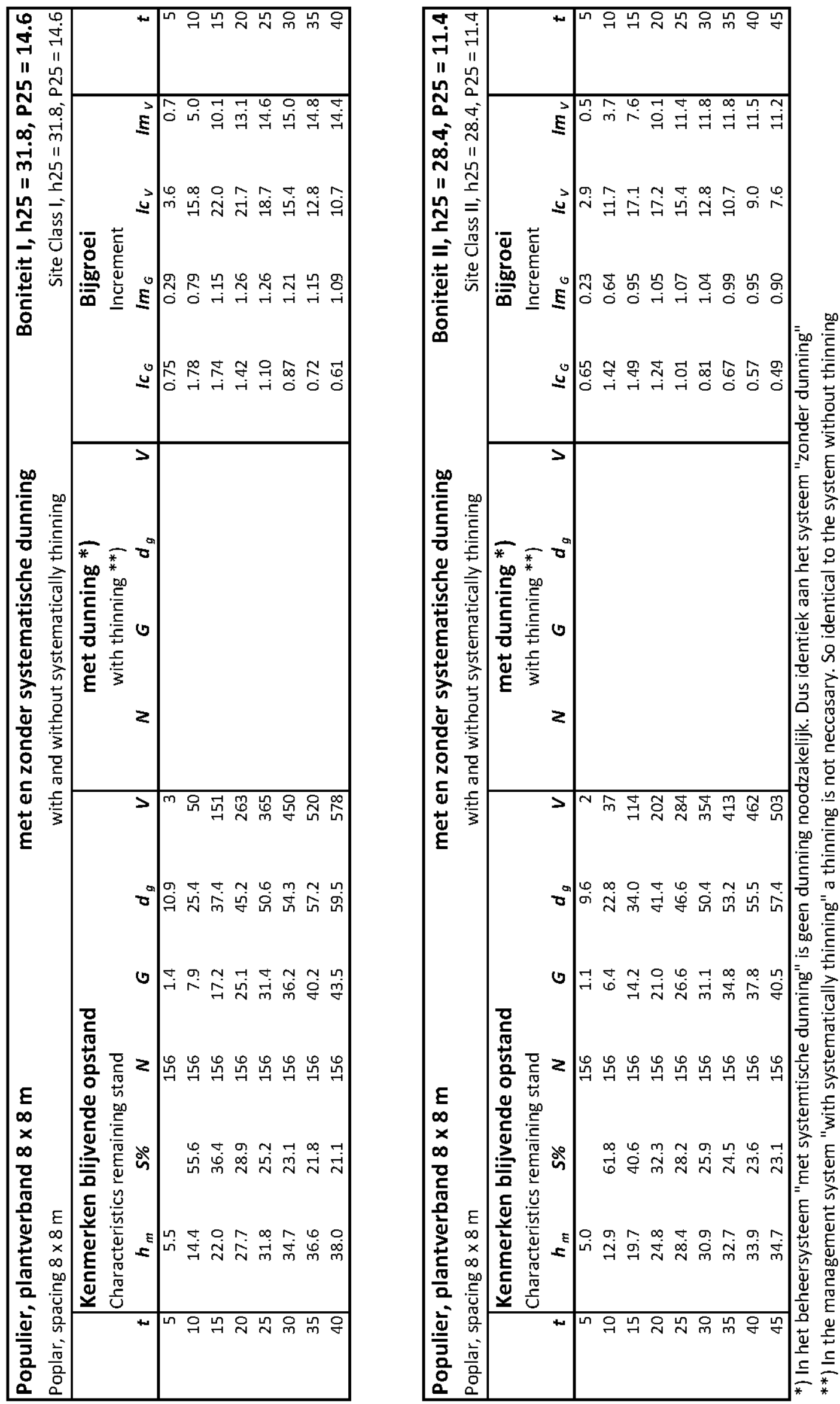

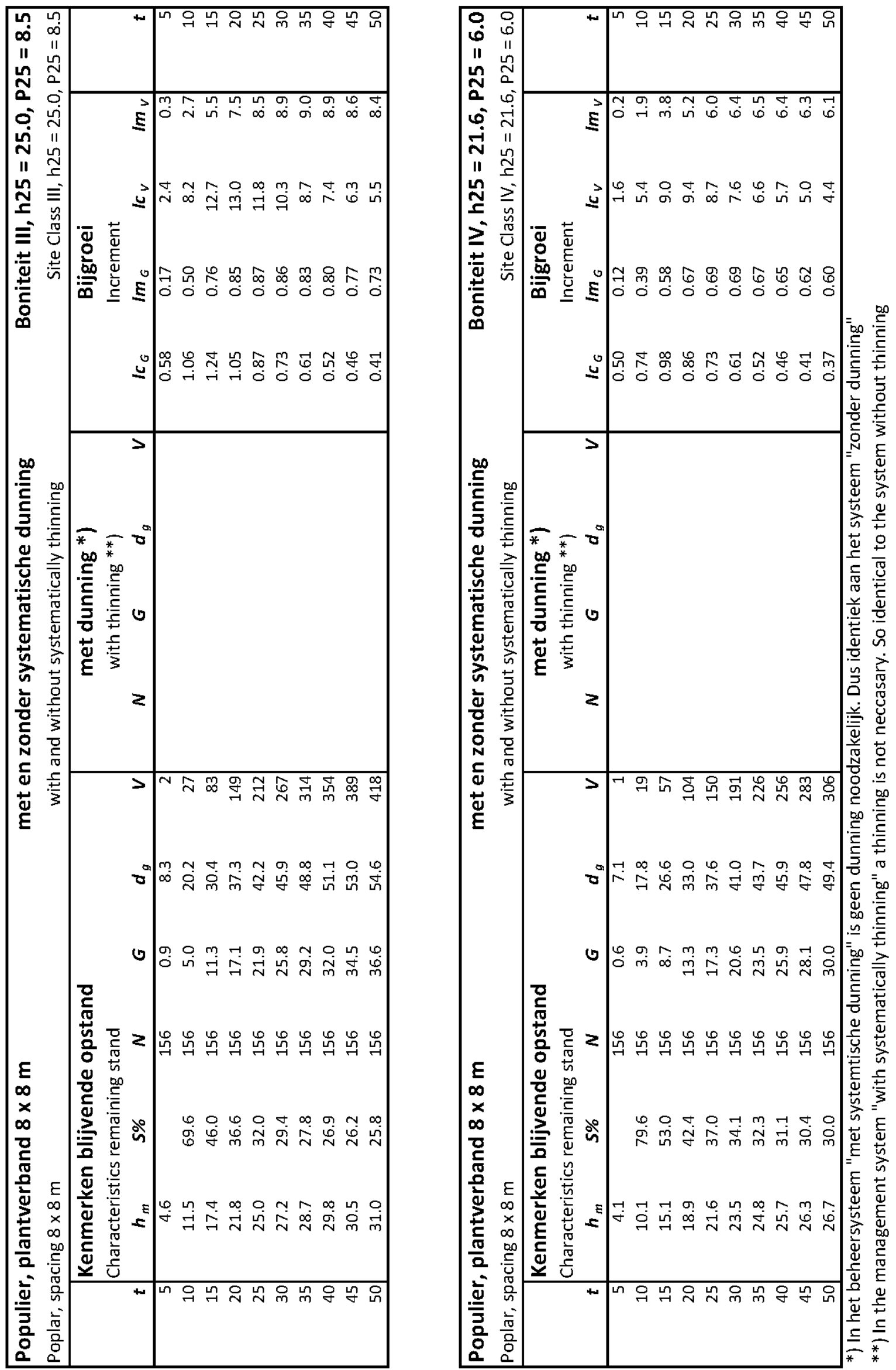


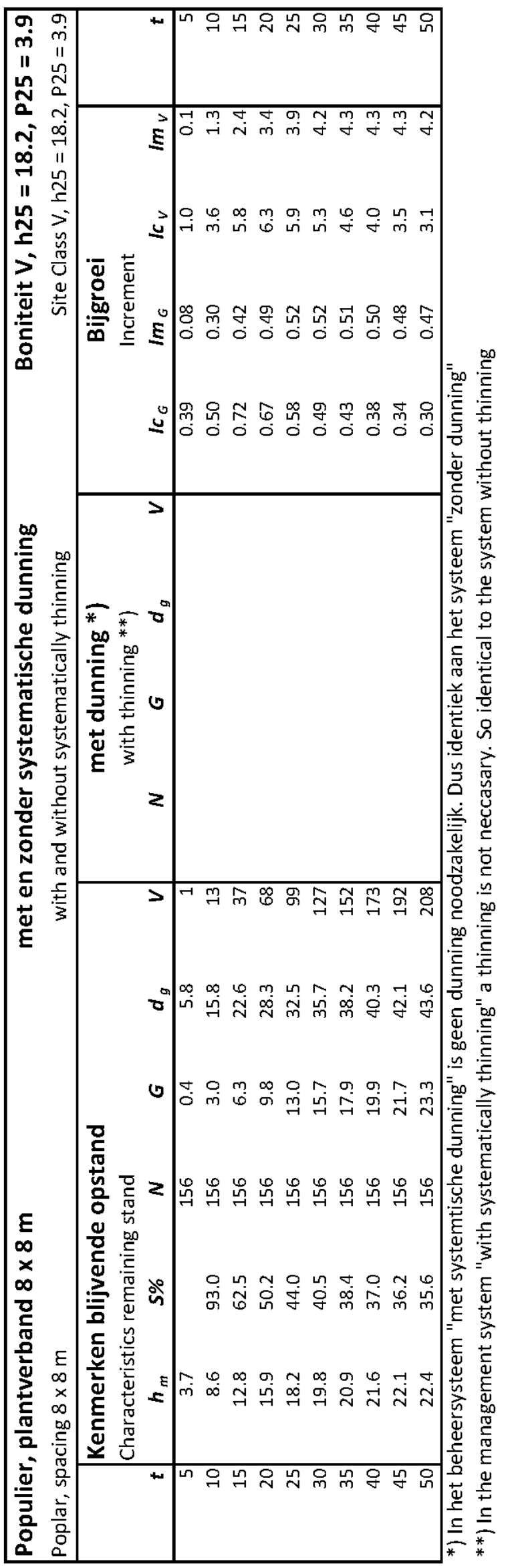



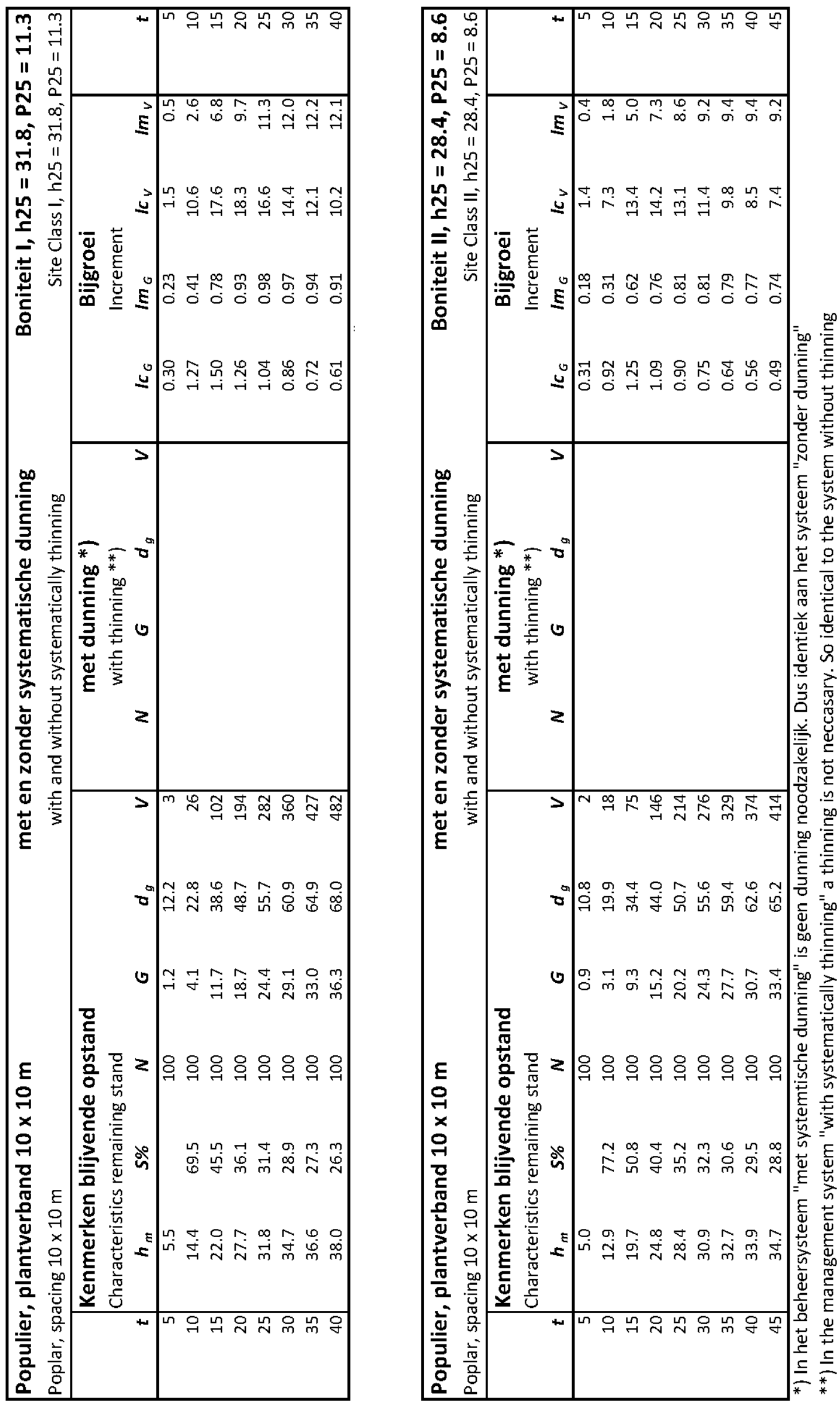

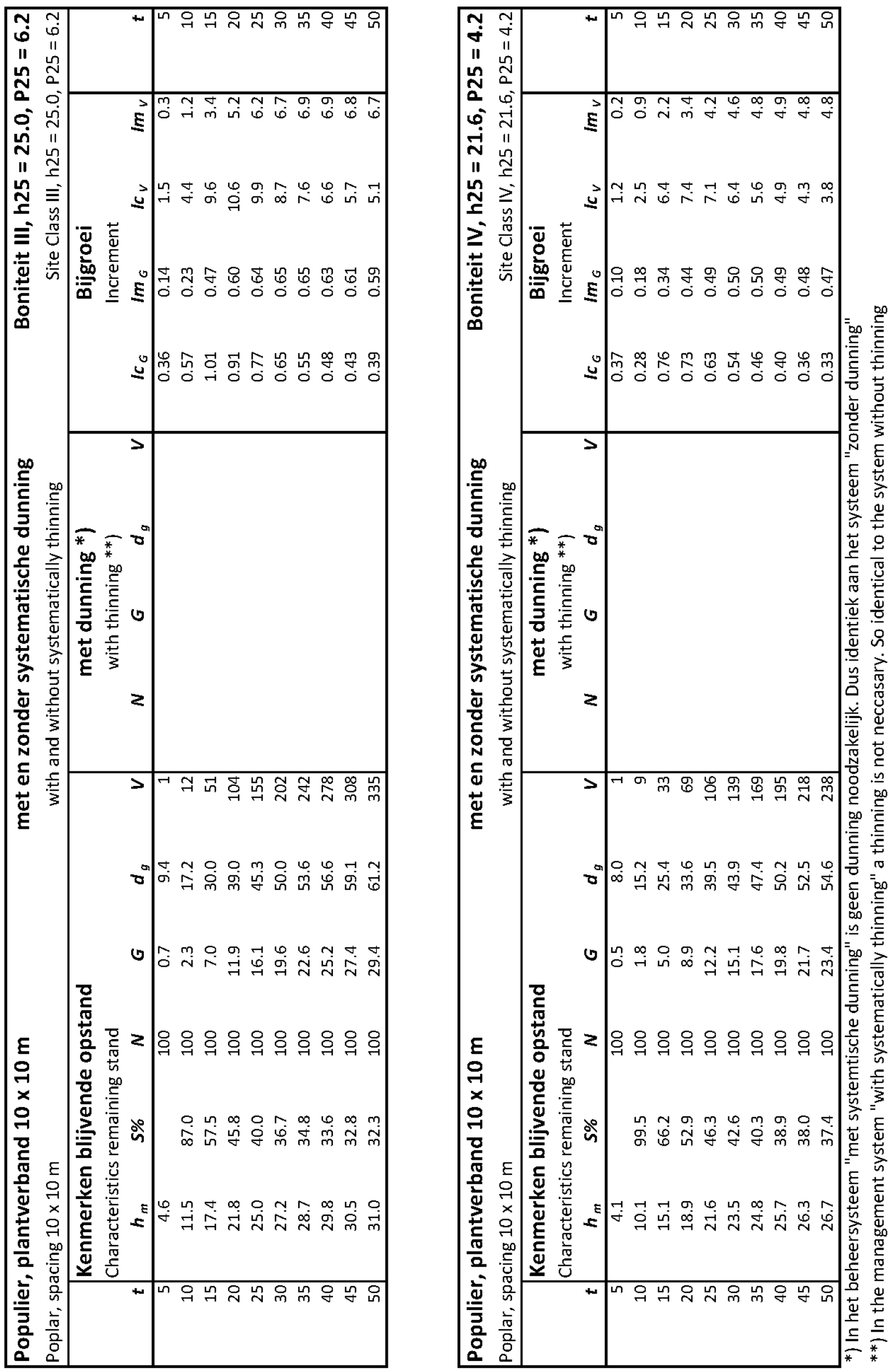


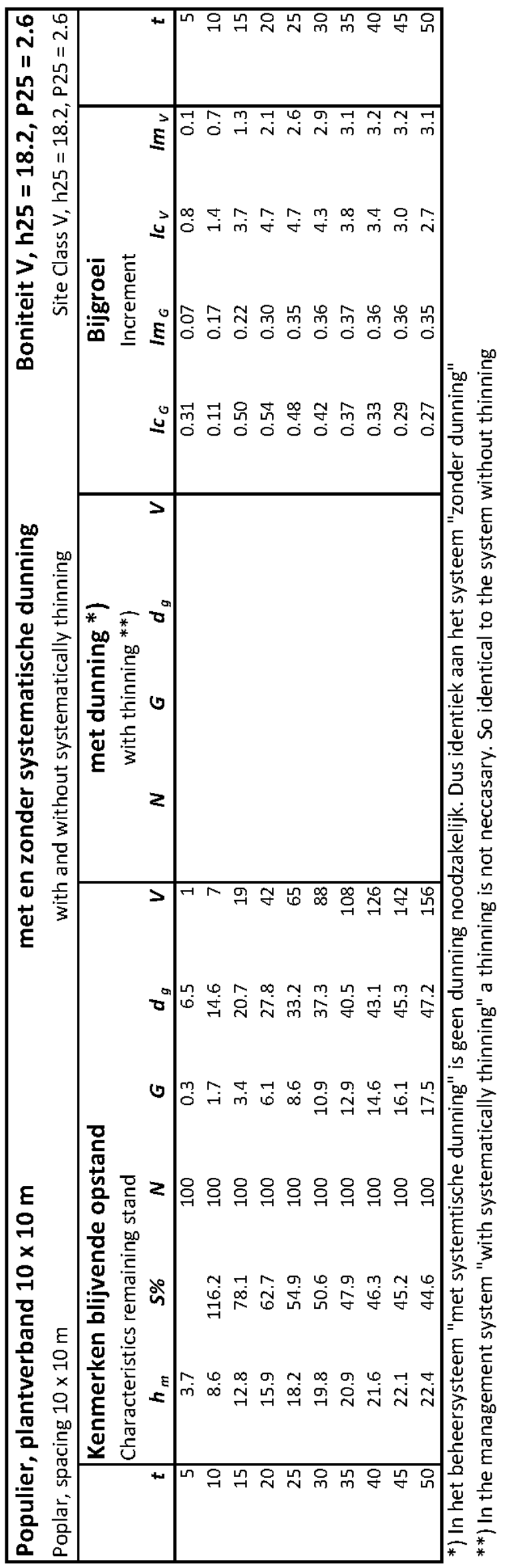



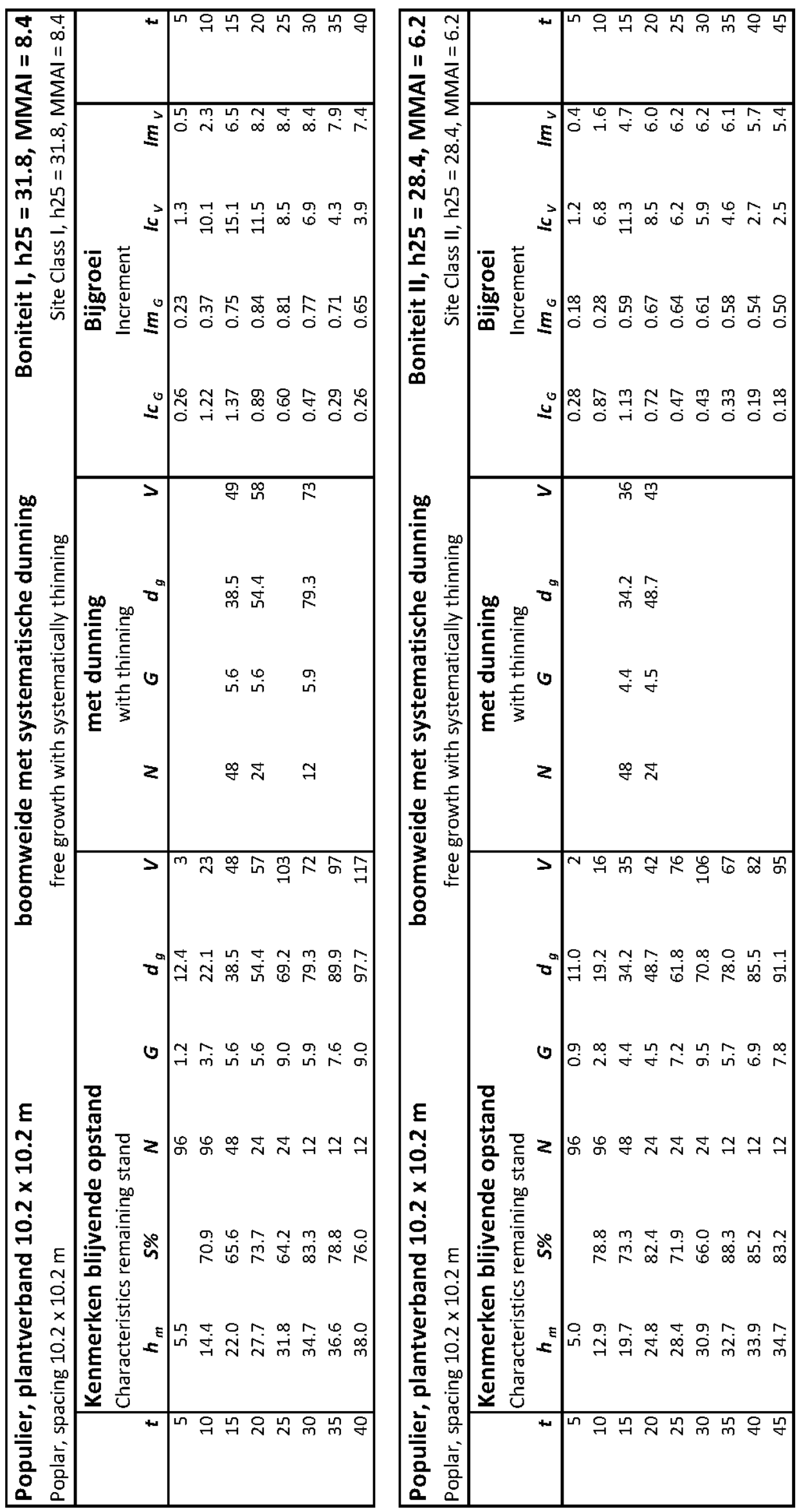


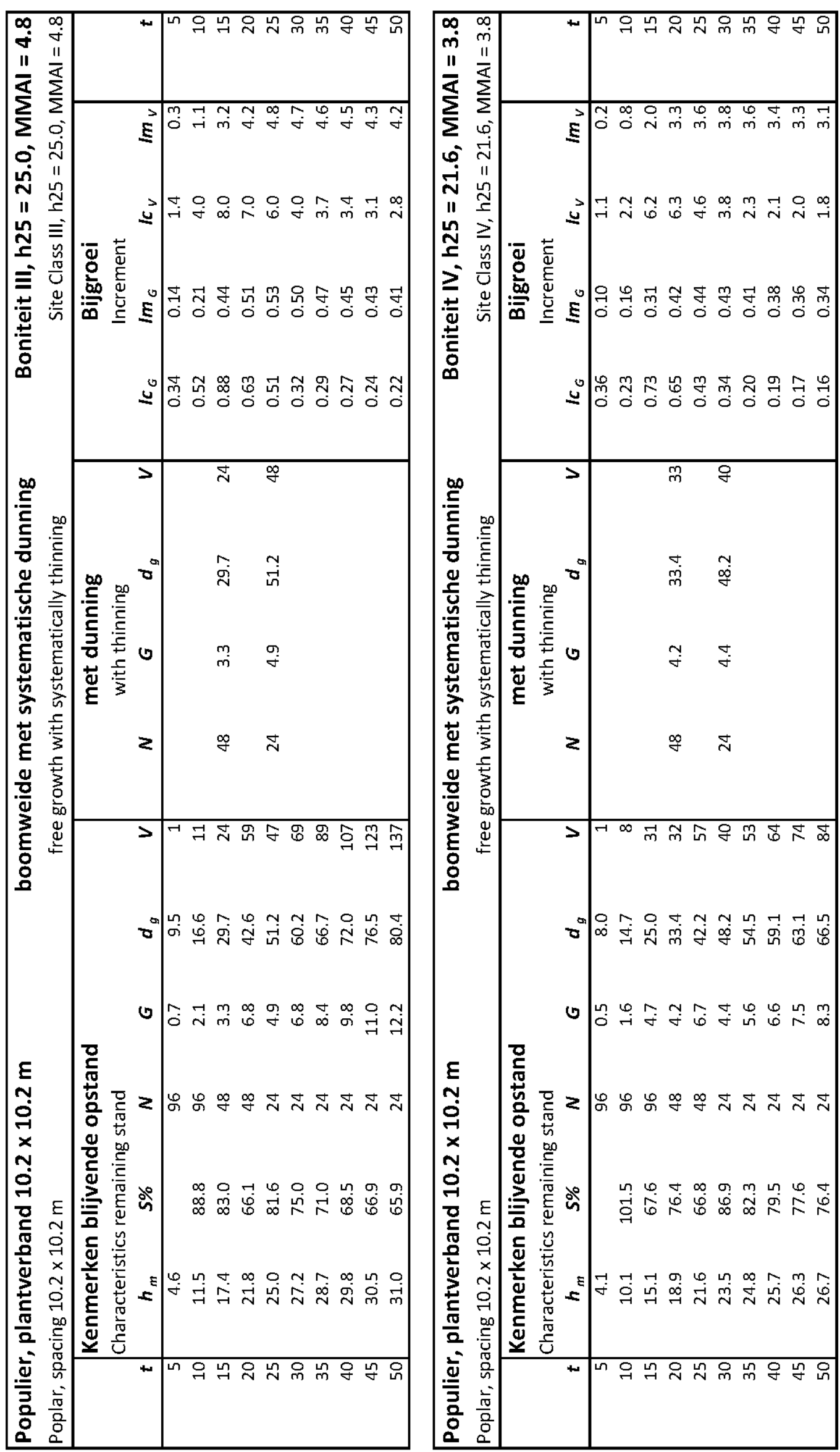




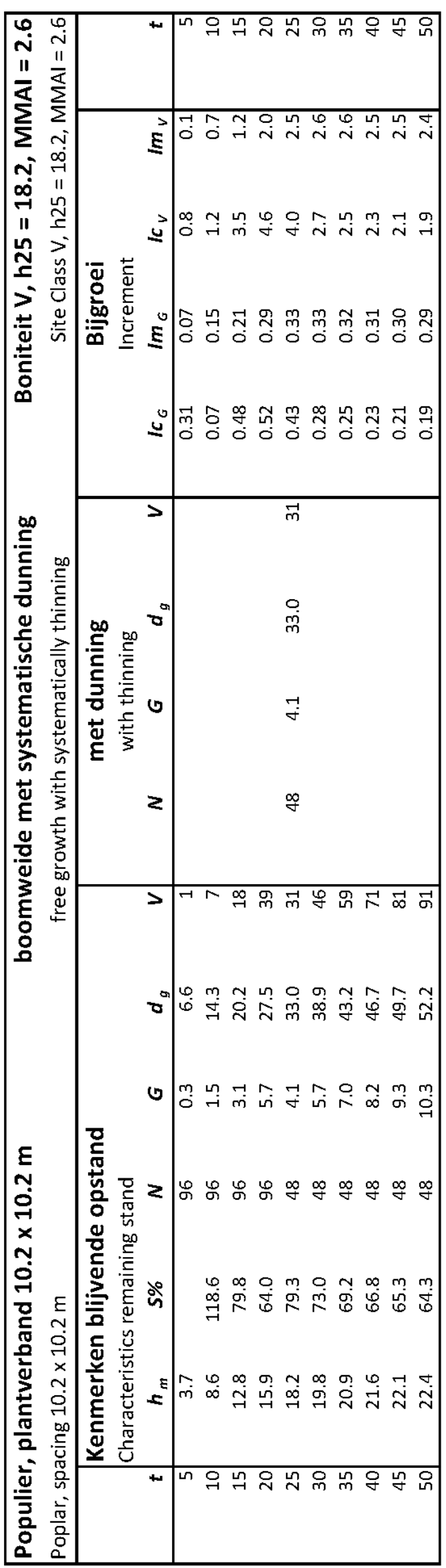



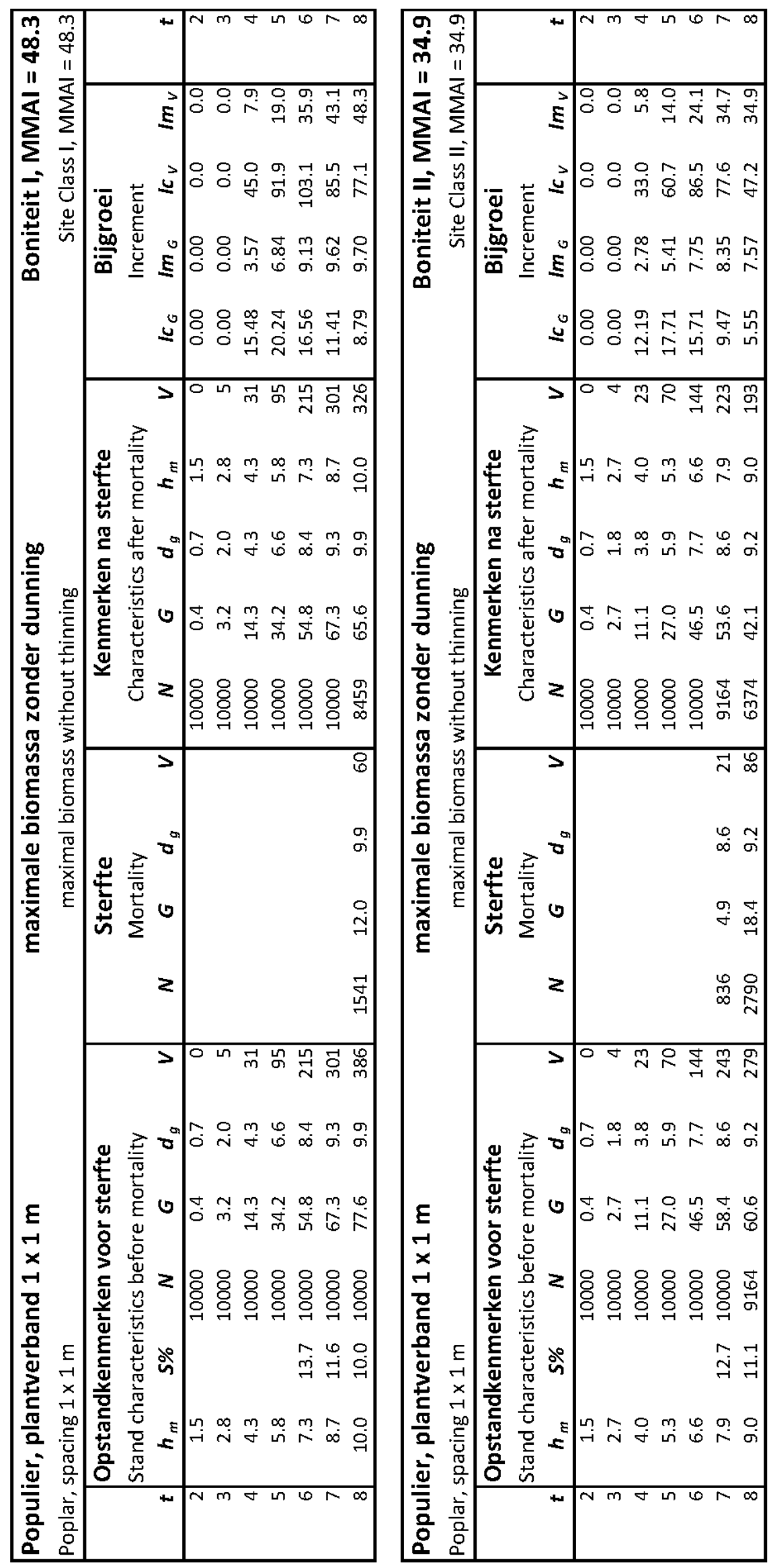


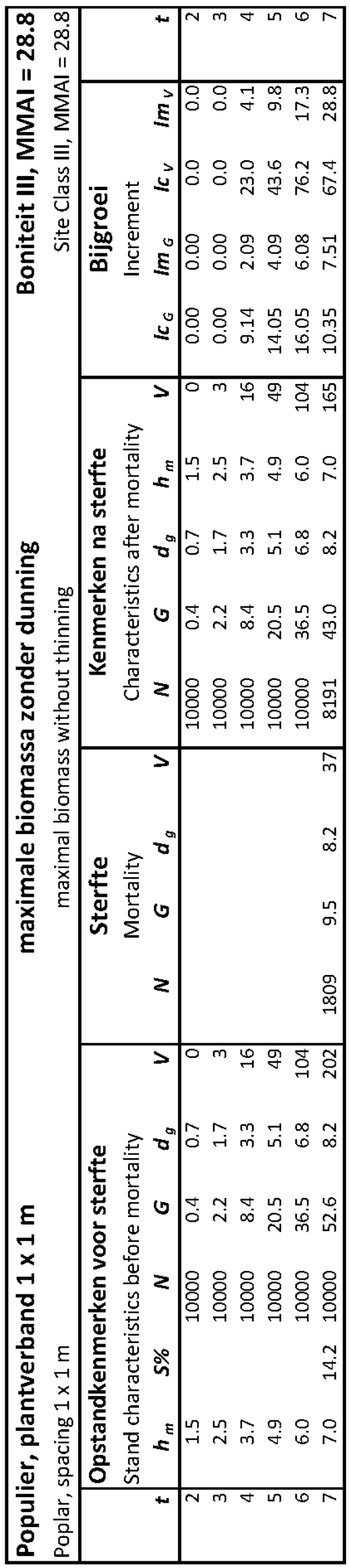



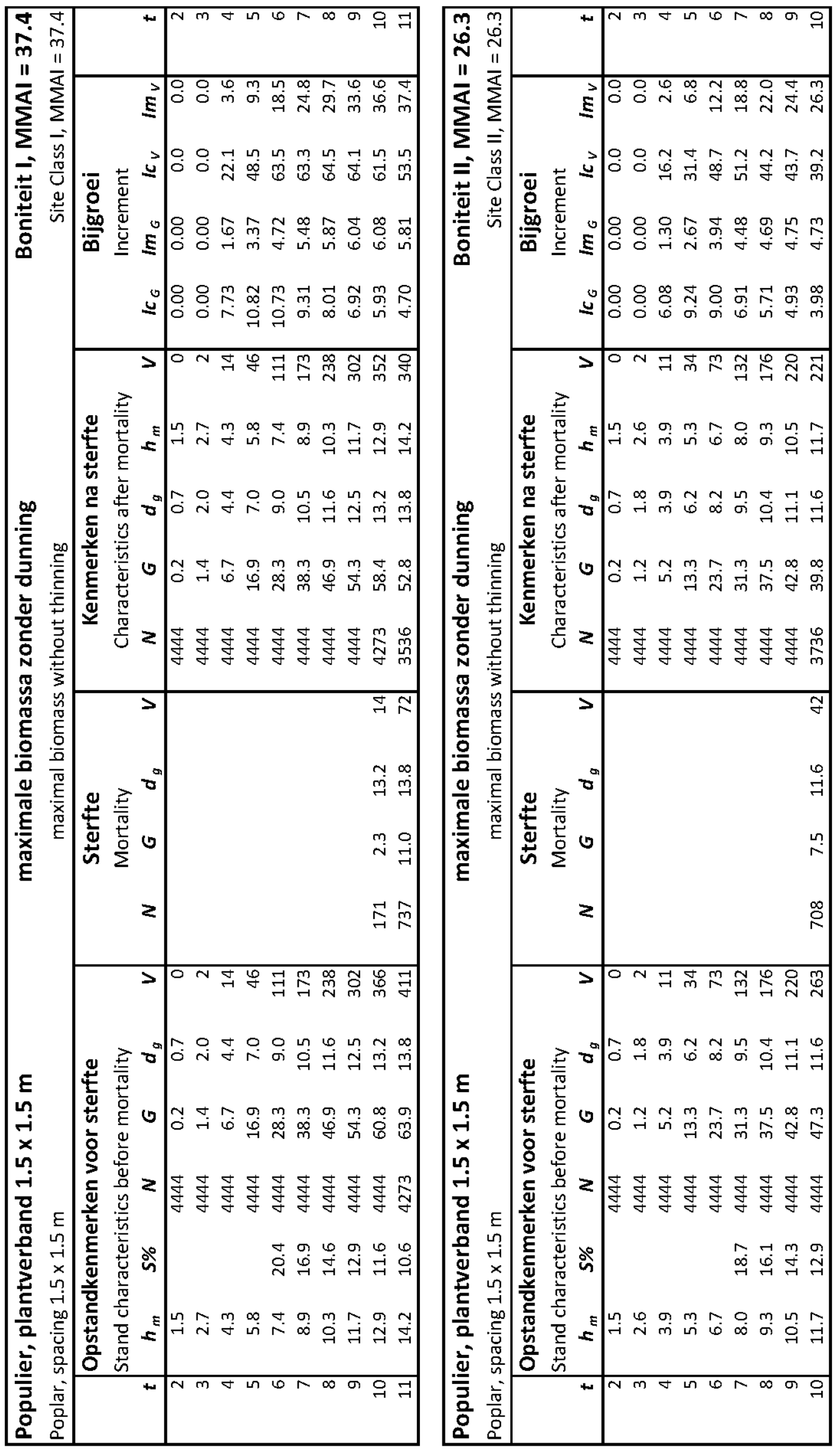


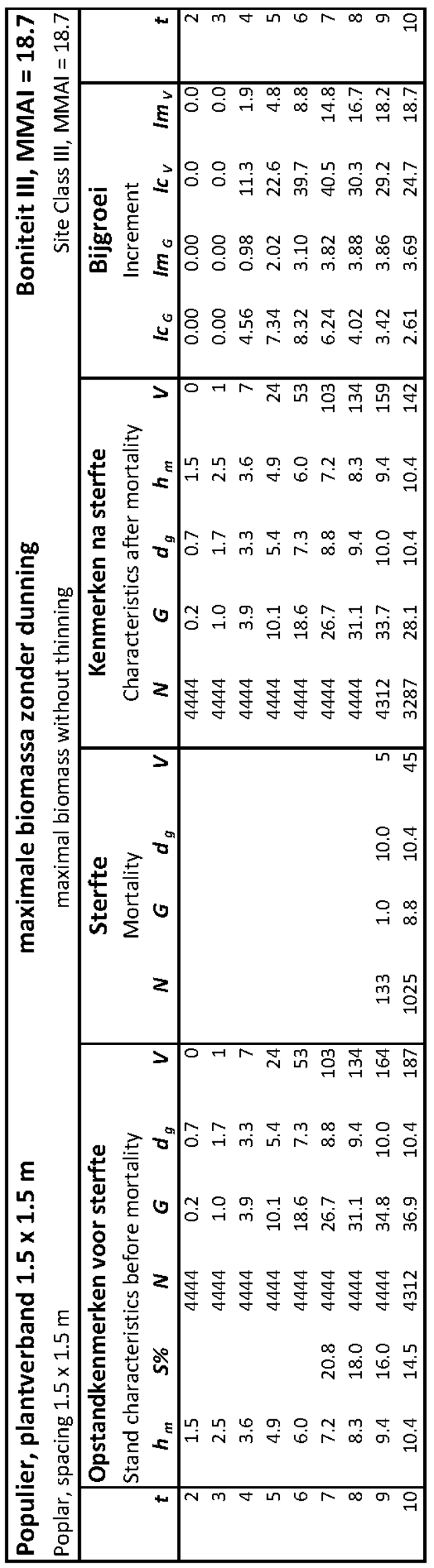



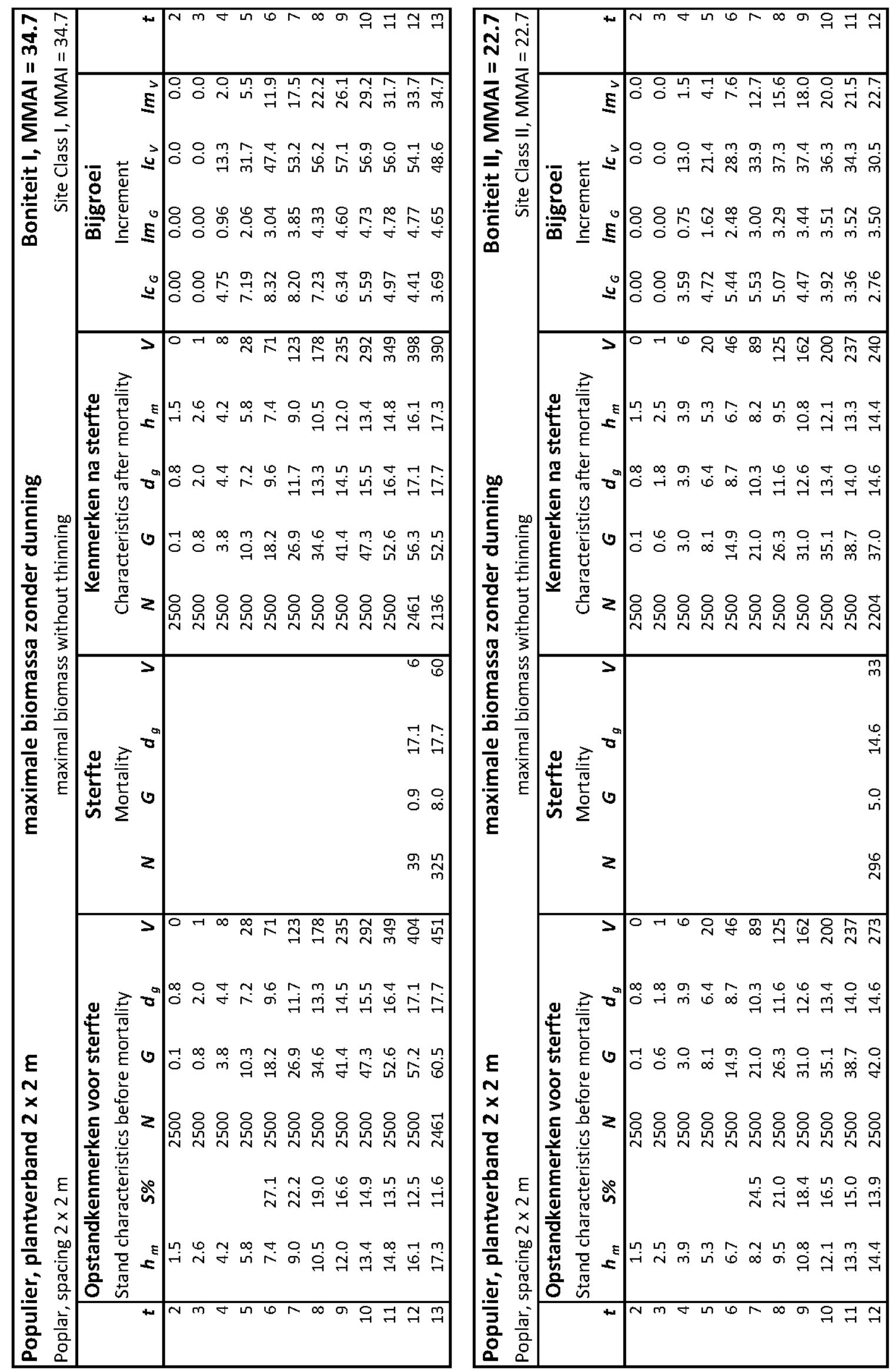


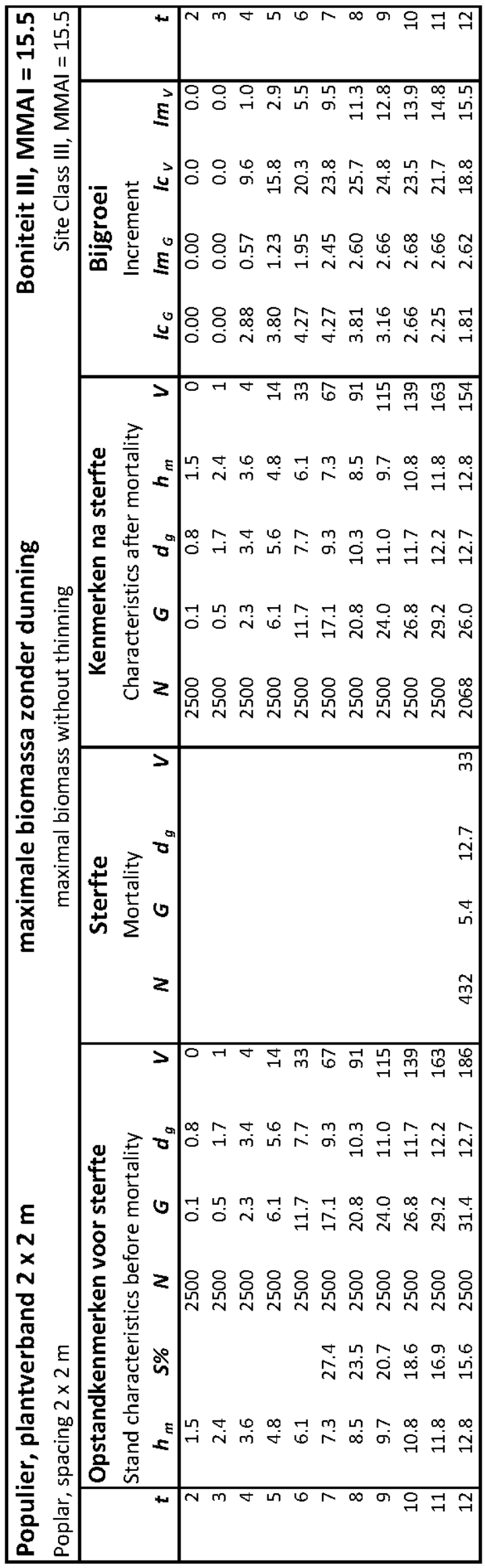




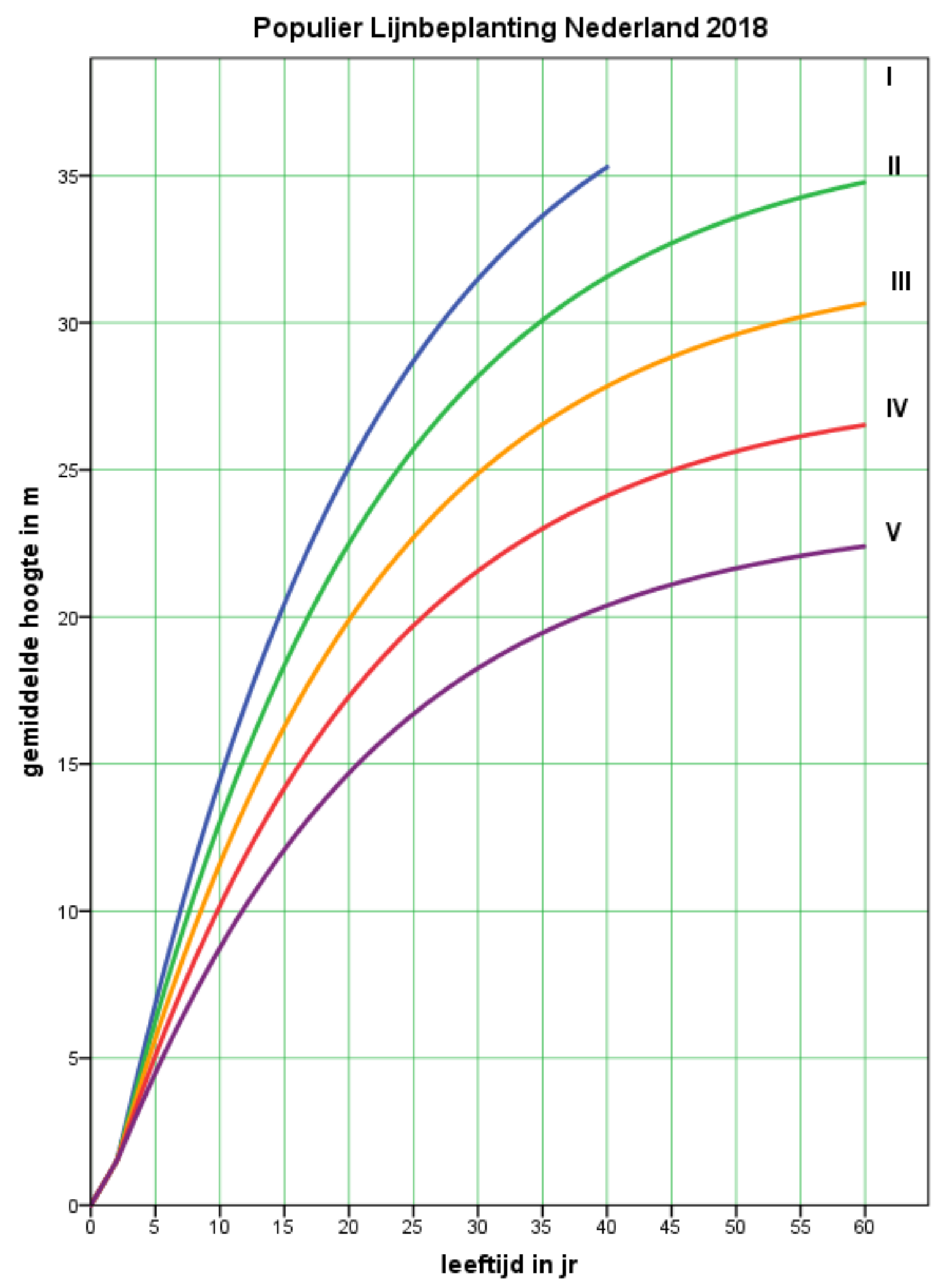




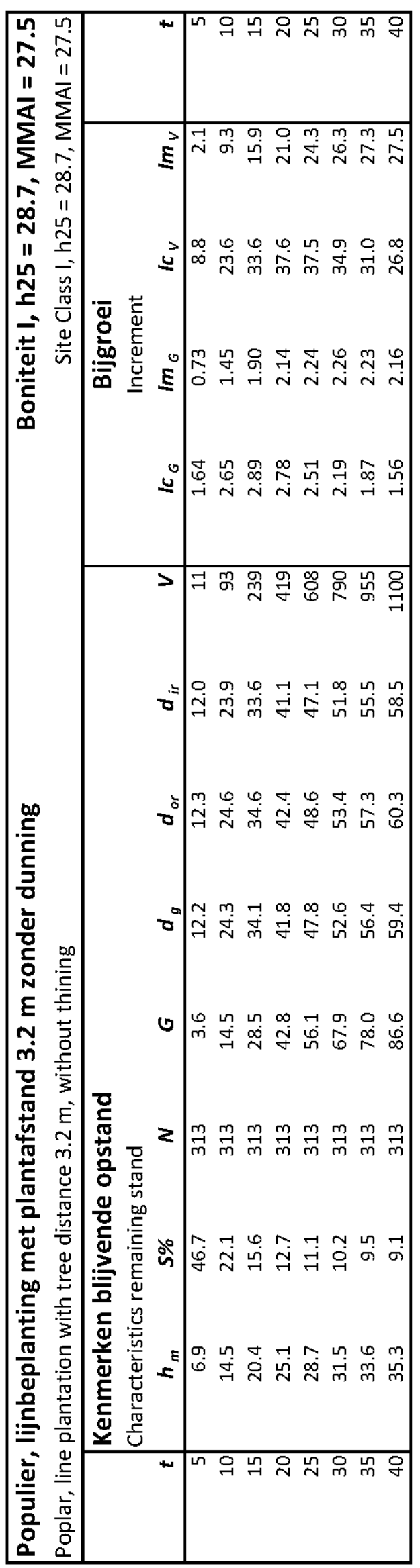




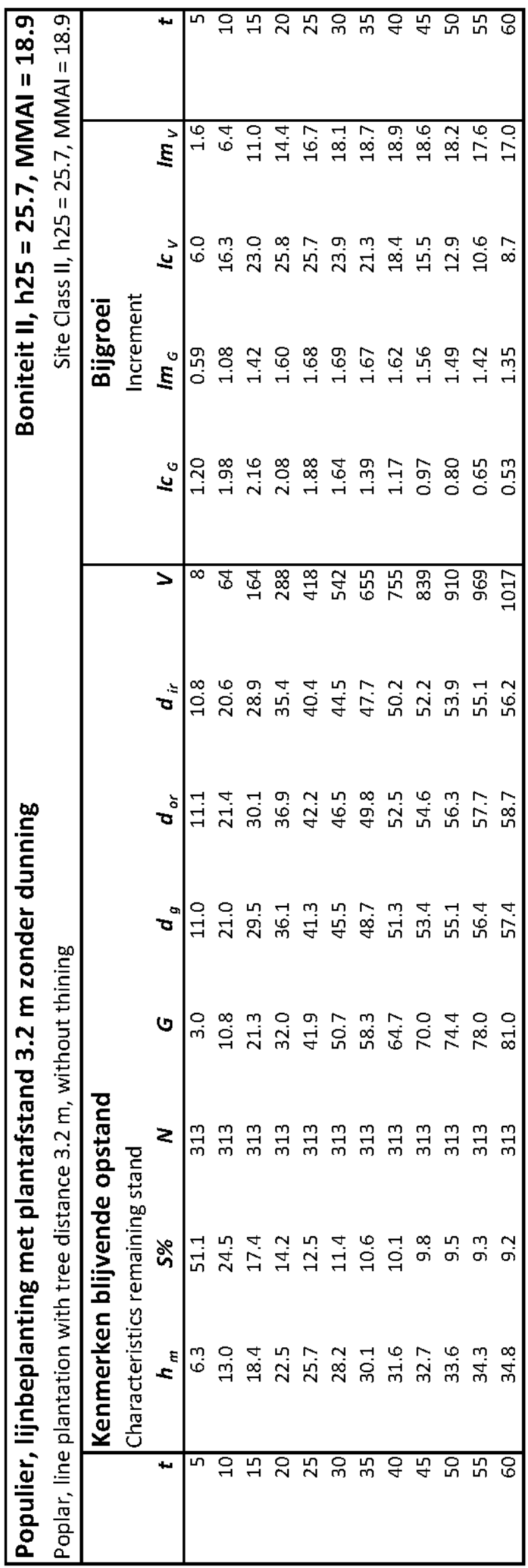




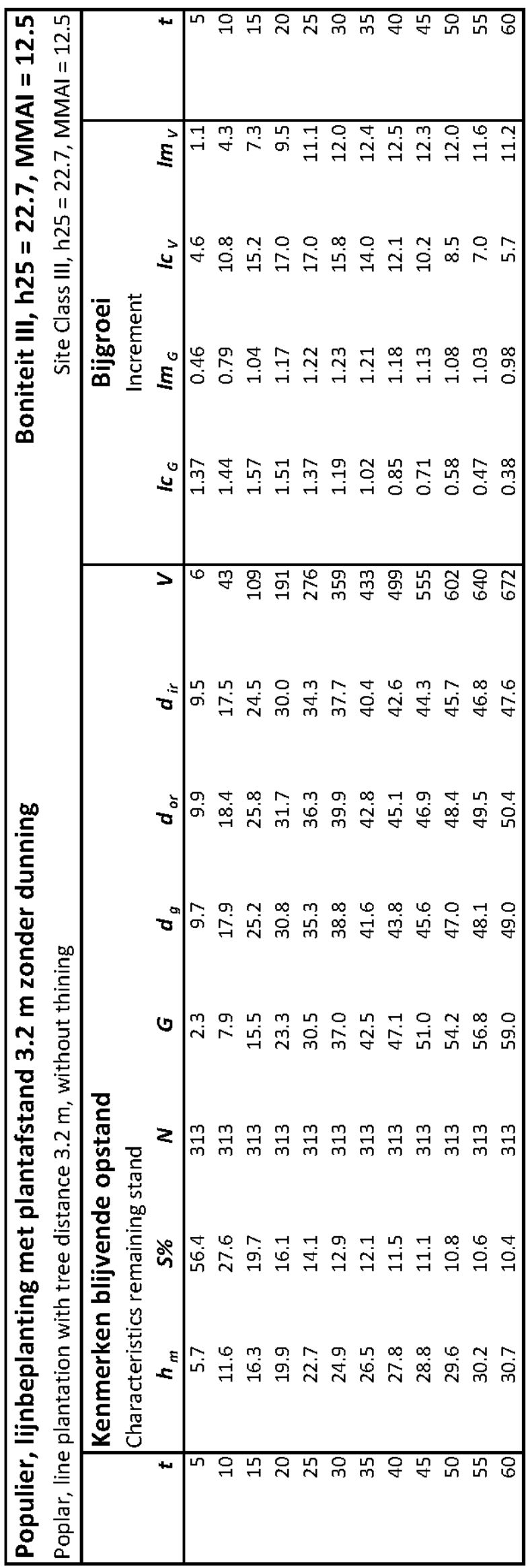




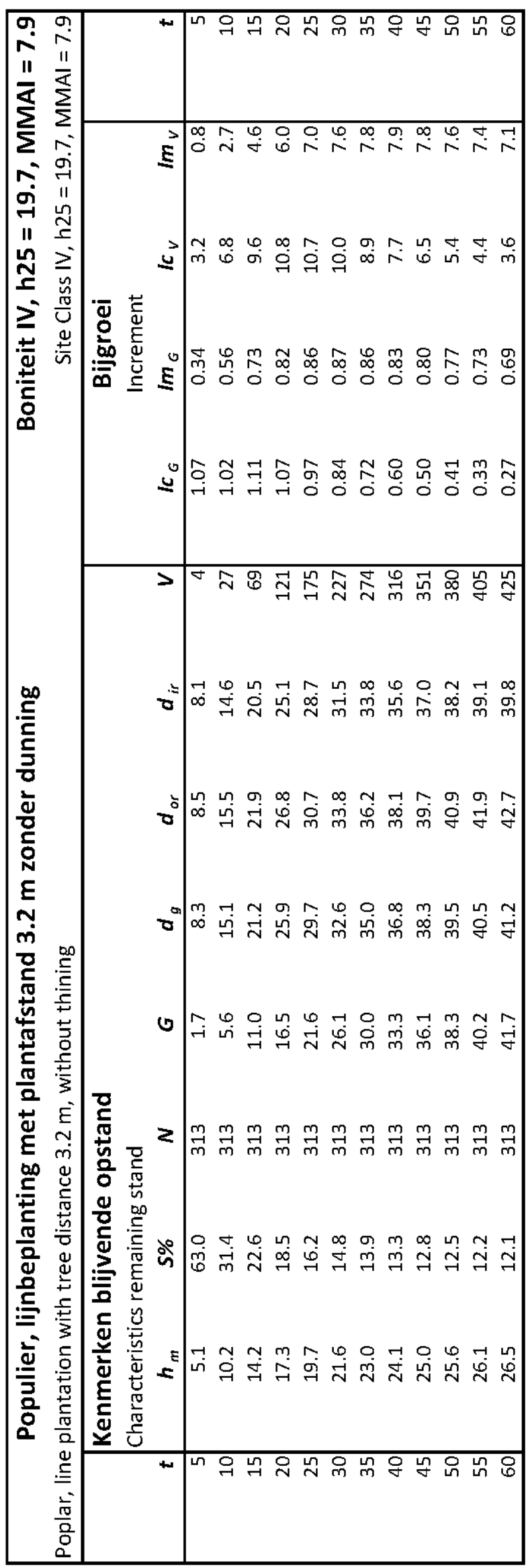




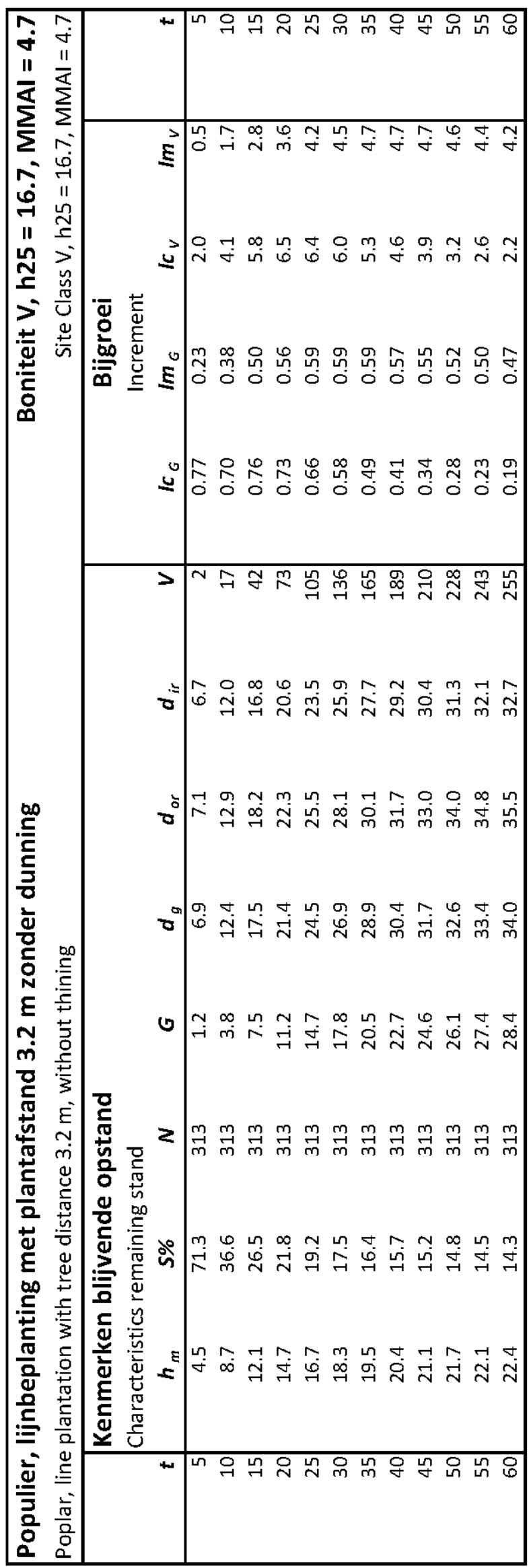




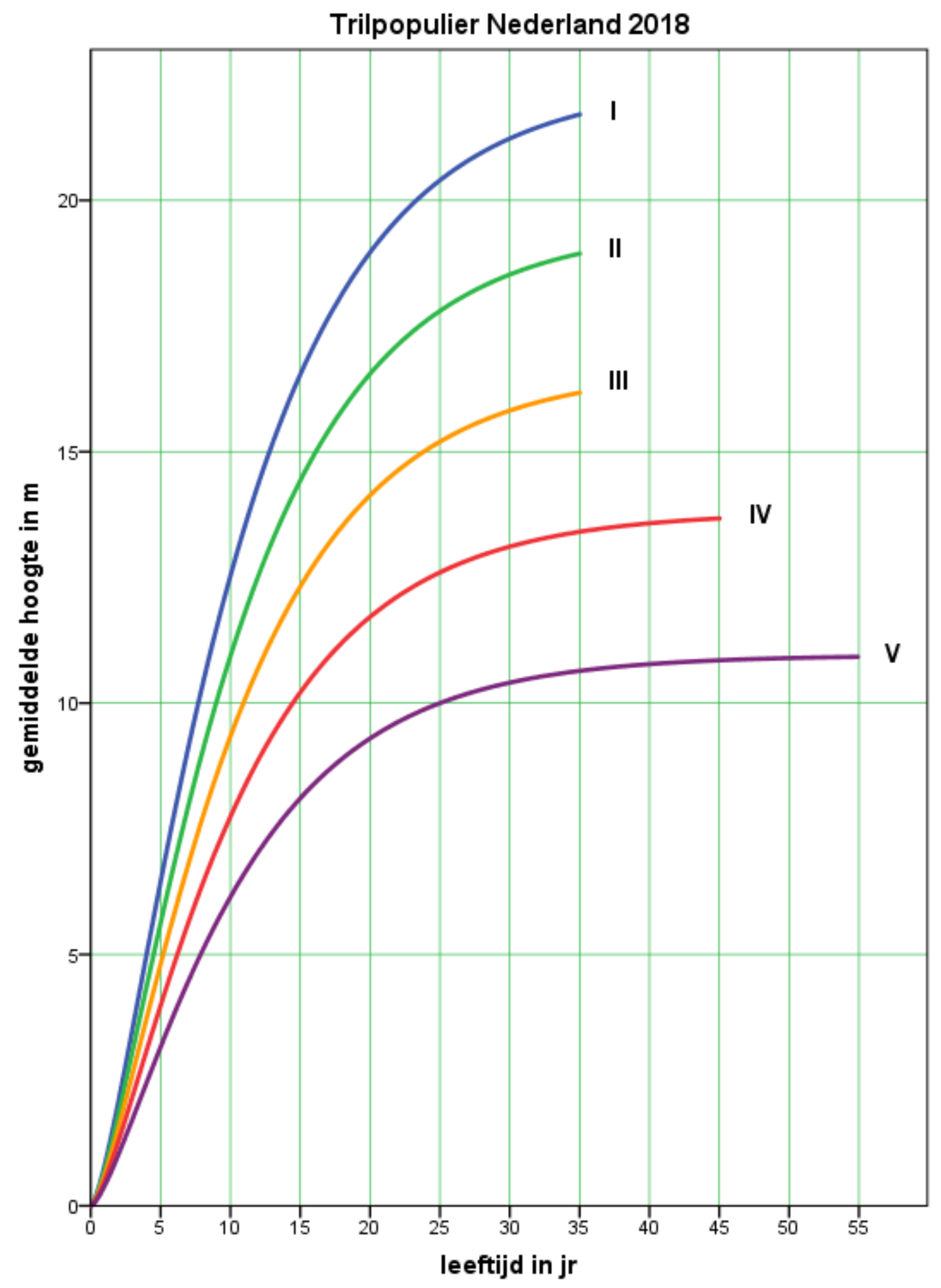



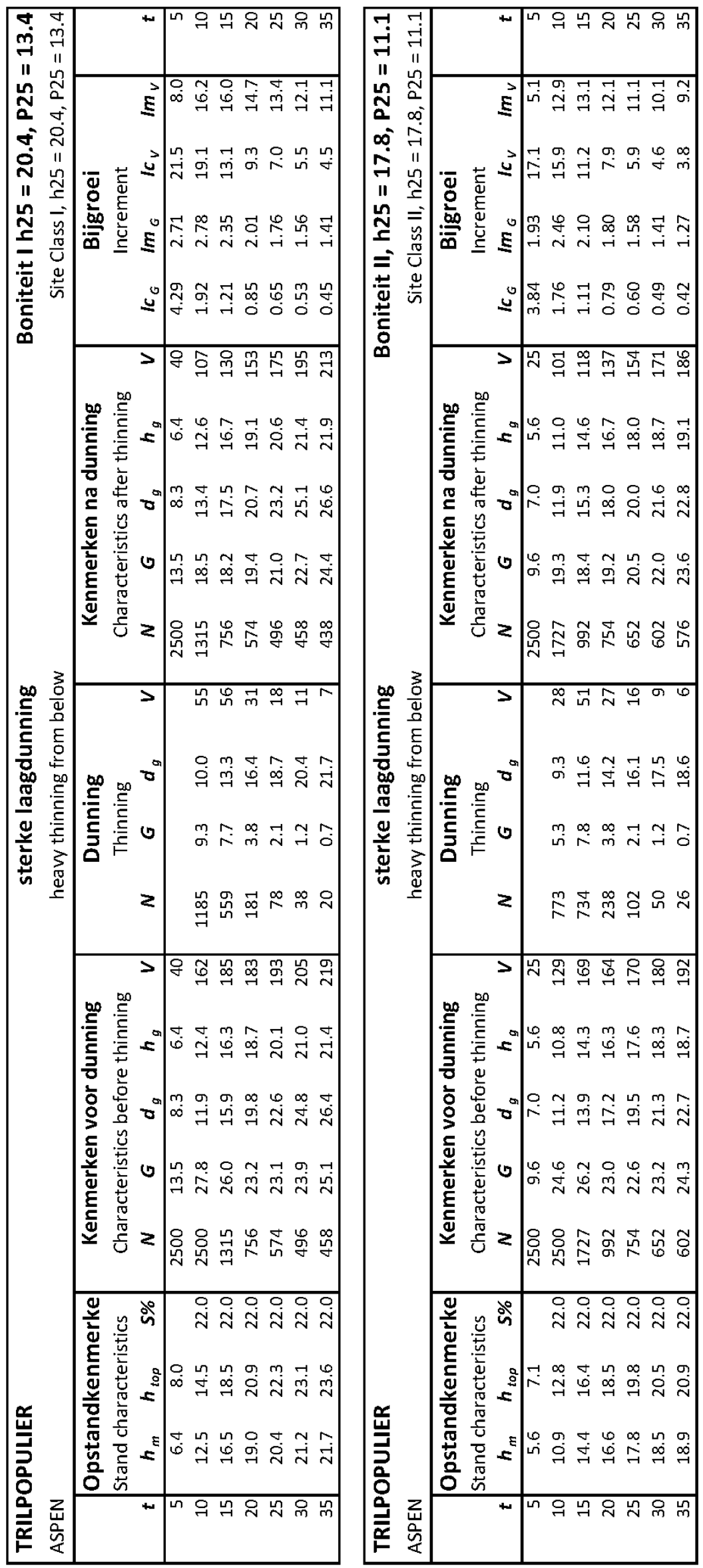

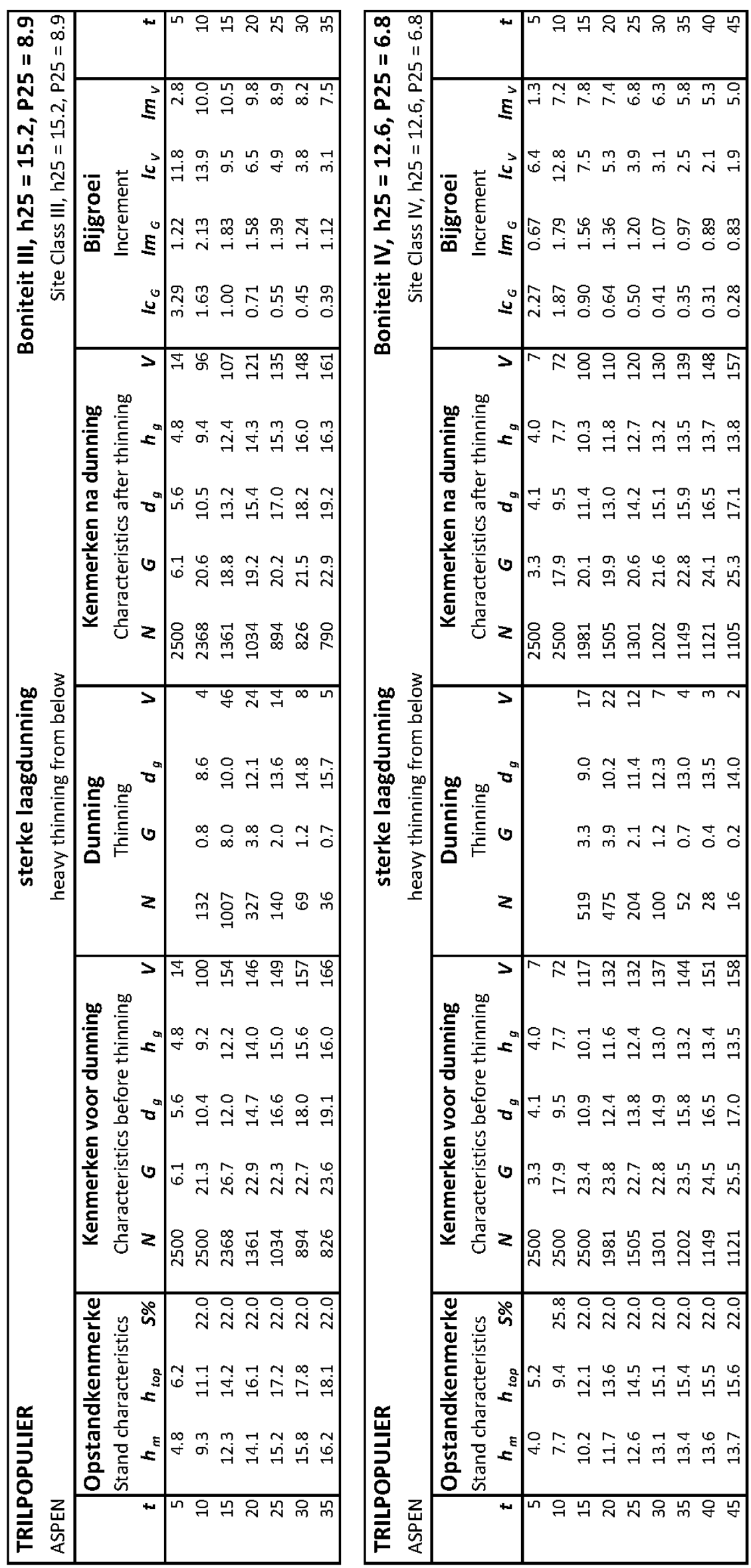


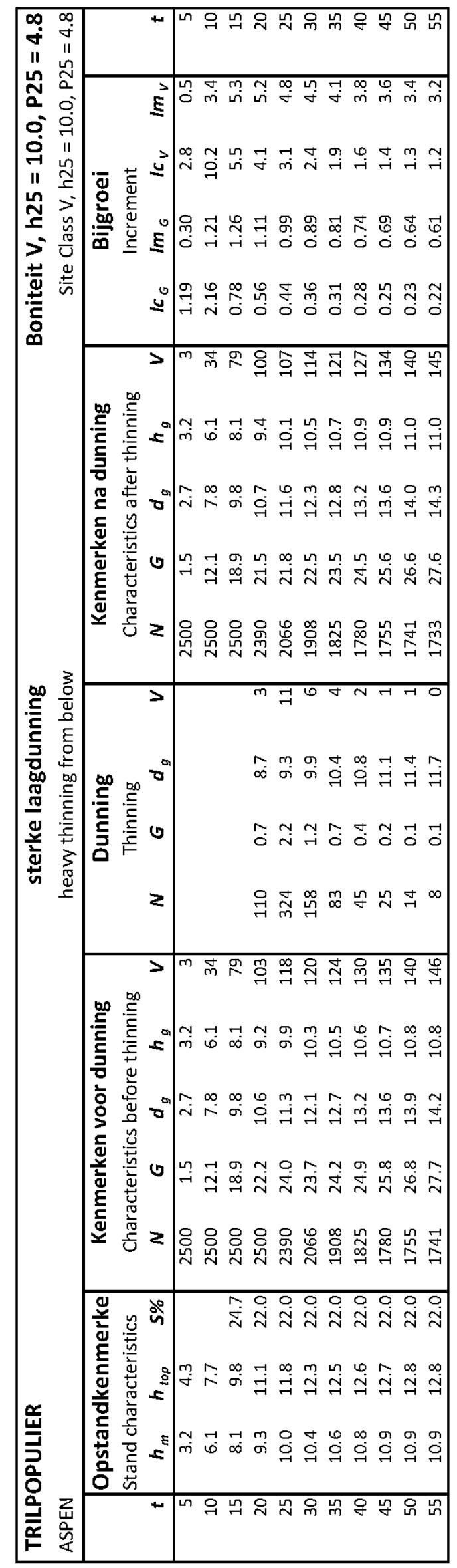

